Jỗo RiCARDo Brandẽo AgUiRre

RESPONSABILIDADE POR INFORMAÇÕES, CONSELHOS OU RECOMENDAÇÕES NAS RELAÇÕES ENTRE PARTICULARES

TESE DE DOUTORADO

Orientadora: Profa. Titular Doutora Teresa AnCona Lopez

FACULDADE DE DIREITO DA UNIVERSIDADE DE SÃo PAULO

São Paulo

2010 
Jỗo RiCARdo BRANDÃo AgUIRRE

\section{RESPONSABILIDADE POR INFORMAÇÕES, CONSELHOS OU RECOMENDAÇÕES NAS RELAÇÕES ENTRE PARTICULARES}

Tese de Doutorado apresentada ao Departamento de Direito Civil da Faculdade de Direito da Universidade de São Paulo, como exigência parcial para a obtenção do título de Doutor em Direito - Área de Concentração: Direito Civil.

Orientadora: Profa. Titular Doutora Teresa Ancona Lopez

FACULDADE DE DIREITO DA UNIVERSIDADE DE SÃO PAULO

SÃO PAULO

2010 
BANCA EXAMINADORA 
Ao meu PAI,

referência de uma vida, que me ensinou a importância do respeito à pessoa humana e a necessidade de se defender a sua dignidade. A dor de uma saudade é proporcional à grandeza de quem se foi. 
À TÂNIA,

essência de todos os meus sentidos.

Aos meus FILHOS,

razão de minha felicidade.

À minha MÃE $e$ IRMÃOS,

depositários de todo o meu afeto. 


\section{AGRADECIMENTOS}

À minha orientadora, professora Teresa Ancona Lopez, por toda a sua dedicação e pelas acuradas observações ao longo de sua orientação, fundamentais para o desenvolvimento desta tese, bem como pela confiança e pelas inúmeras manifestações de gentileza, que, aliados ao profundo conhecimento do Direito e da natureza humana, constituem exemplos a serem seguidos por qualquer docente.

Aos amigos Gilberto Bergstein e João Marques, que me cederam um espaço fundamental para que o presente trabalho pudesse ser desenvolvido, além das inúmeras discussões jurídicas regadas a um bom café, em manifestação única e inequívoca de amizade e de desprendimento, a quem devo minha mais sincera gratidão.

Aos amigos Patrícia Faga Iglecias Lemos, Fabio Simões Abrão, Marcelo Truzzi Otero, Renato Montans de Sá, Luiz Fernando Rangel de Paula, Brunno Pandori Giancoli, Guilherme Madeira Dezem e Selma Ramos Pereira, por sua valiosa contribuição para o desenvolvimento e conclusão desta tese e por traduzirem o sentido da palavra amizade. 


\section{RESUMO}

A evolução das relações sociais, o acelerado avanço tecnológico e a dinâmica das relações comerciais fizeram com que o conhecimento e a informação se tornassem bens de inegável valor em um mundo globalizado e em constante transformação. Como conseqüência, a informação constitui instrumento essencial para o desenvolvimento das relações humanas, e sua transmissão pauta-se, em regra, pela confiança depositada nos diversos interlocutores. No entanto a troca de informações pode acarretar a quebra dessa confiança, causando danos à pessoa ou ao patrimônio e dando origem à obrigação de repará-los. O presente trabalho, desenvolvido a partir de compilação doutrinária e jurisprudencial, objetiva proceder à análise e discussão da responsabilidade daqueles que dão informações, conselhos ou recomendações a outrem, em especial no que tange às relações entre particulares. $\mathrm{O}$ exercício potencialmente danoso do dever de informar, a negligente transmissão de um parecer ou de um simples esclarecimento e os prejuízos daí decorrentes justificam o estudo mais detalhado deste tema. Assim, pretende-se discorrer sobre os fundamentos do dever de informar, de dar conselhos ou recomendações, tomando-se por base a ordem de valores de nosso ordenamento, alicerce necessário para o desenvolvimento das relações pessoais e fonte de um dever ético de conduta, a fim de demonstrar a existência de uma responsabilidade pela quebra da confiança depositada no sistema jurídico brasileiro, cuja violação gera a obrigação de reparação dos danos que dela decorram. Sobre essa base valorativa, nosso trabalho objetiva proceder à análise da responsabilidade pelos danos causados nas relações entre particulares, em virtude de conselhos, recomendações ou informações, seja na fase que antecede a formação do contrato, seja na fase de sua conclusão e execução ou até mesmo posteriormente à sua extinção.

Palavras-chave: Responsabilidade civil - Informação - Conselho - Recomendação Confiança - Boa-fé objetiva - Novos paradigmas. 


\begin{abstract}
The development of social relationships, the swift technological advancements, and the dynamics of business relations have turned knowledge and information into invaluable assets in an ever changing, globalized world. As a result, information has become a fundamental tool in the development of human relations. Disclosure of information is currently subject to the mutual reliability exercised by the several actors involved in the process. However, exchanging information may lead to a failure in complying with such reliability, which is likely to cause ultimate damage to persons or assets and therefore result in the obligation to repair. This paper was prepared on the basis of data gathered from case law and legal rules, and aims to review and discuss the liability assigned to those who provide information, counseling and recommendations to third parties, particularly within the framework of private parties. The reasons for a more detailed approach to this issue lie on the potentially damaging nature of the obligation to inform and the damage that is likely to result from the reckless rendering of either an opinion or more specific information. This paper will approach the fundamentals of the obligation to render information, counseling or recommendations on the basis of the Brazilian legal system, which is not only a pillar of personal relations development, but also a source for ethical conduct obligation. To a larger extent, it aims to provide evidence that liability stems from relying on the Brazilian legal system, and that failure to comply with said system will lead into the obligation of repairing the damage incurred. Based on these values, this paper will further review the liability derived from providing counseling, recommendations or information within the scope of private parties' relationships. This applies to the initial stages of an agreement as well as the termination and settlement thereof and the procedures following thereafter.
\end{abstract}

Keywords: Civil liability - Information - Counsel - Recommendation - Good faith Trust. 


\section{RÉSUMÉ}

L'évolution des rapports sociaux, le progrès technologique accéléré et la dynamique des relations commerciales ont amené à ce que la connaissance et l'information deviennent des biens d'une valeur indéniable dans un monde mondialisé et en transformation continuelle. Par conséquent, l'information constitue un instrument essentiel pour le développement des rapports humains, et sa transmission est fondée, en général, sur la confiance placée dans les différents interlocuteurs. Cependant, l'échange d'informations peut entraîner la rupture de cette confiance et causer des dommages à la personne ou au patrimoine et faire naître, en conséquence, l'obligation de les réparer. Le présent travail, développé à partir de la compilation doctrinaire et jurisprudentielle, a pour but de procéder à l'analyse et à la discussion de la responsabilité de ceux qui donnent des informations, des conseils ou des recommandations à autrui, surtout en ce qui concerne les rapports entre les particuliers. L'exercice potentiellement nuisible du devoir d'informer, la transmission négligente d'un avis ou d'un simple éclaircissement ainsi que les pertes qui en découlent justifient l'étude plus détaillée de ce sujet. Ainsi, nous prétendons discuter les fondements du devoir d'informer, de donner des conseils ou recommandations, ayant comme base l'ordre de valeurs de notre ordonnancement, un fondement nécessaire pour le développement des rapports personnels et une source d'un devoir éthique de conduite, afin de démontrer l'existence d'une responsabilité de la rupture de la confiance placée dans le système juridique brésilien, dont la violation génère l'obligation de réparation des dommages qui en découlent. Fondé sur cette base de valeur, notre travail a pour but de procéder à l'analyse de la responsabilité des dommages causés dans les rapports entre les particuliers, en vertu de conseils, de recommandations ou d'informations, soit dans la phase qui précède la formation du contrat, soit dans la phase de sa conclusion et exécution, ou même après sa fin.

Mots-clé: Responsabilité civile - Information - Conseil - Recommandation - Bonne foi - confiance. 


\section{SUMÁRIO}

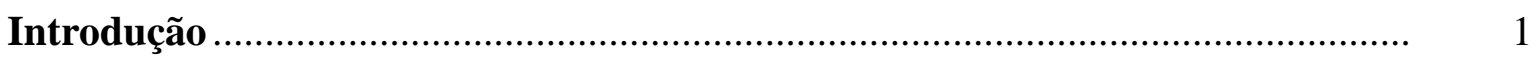

1. Novos paradigmas da responsabilidade civil........................................ 7

1.1 A evolução tecnológica e os seus riscos ………........................................ 7

1.2 Da responsabilidade extracontratual .................................................... 20

1.2.1 Culpa e risco .................................................................. 22

$1.3 \quad$ Da responsabilidade contratual ............................................................ 32

1.3.1 A autonomia privada .......................................................... 35

1.3.2 A função social do contrato .................................................... 40

1.3.3 A boa-fé objetiva ...................................................................... 46

2. A teoria da confiança e o princípio da boa-fé objetiva como base fundamental para o desenvolvimento das relações entre particulares em nosso sistema de direito privado

2.1 A teoria da confiança e o seu fundamento ético-jurídico .......................... 47

2.2 A confiança e as teorias fundamentadoras do negócio jurídico.................. 50

2.3 O princípio da boa-fé objetiva …........................................................... 58

2.3.1 A tríplice função da boa-fé objetiva ........................................... 64

2.3.1.1 A função interpretativa da boa-fé .................................. 65

2.3.1.2 A função supletiva da boa-fé ......................................... 67

2.3.1.3 A função corretiva da boa-fé......................................... 74

2.3.2 Do abuso de direito ................................................................. 75

3. A confiança como um dos valores fundantes da responsabilidade civil no sistema jurídico brasileiro. fundamentos de uma responsabilidade pela confiança

3.1 O direito civil e a Constituição Federal de 1988 ........................................ 85

3.2 A eficácia dos princípios constitucionais no âmbito das relações de direito privado

3.3 A base valorativa do sistema brasileiro e os mecanismos para a sua abertura: princípios, conceitos legais indeterminados e cláusulas gerais

4. A responsabilidade por informações, conselhos e recomendações no direito brasileiro contemporâneo. 
4.1 Delimitação do tema: o conceito de informação, conselho e recomendação 131

4.2 A responsabilidade pela informação, o conselho e a recomendação, na fase pré-contratual .................................................................................... 142

4.2.1 A responsabilidade pré-contratual ........................................... 143

4.2.2 A natureza jurídica da responsabilidade pré-contratual.............. 149

4.2.3 A responsabilidade pela informação, o conselho e a recomendação, na fase pré-contratual .............................................................. 156

4.3 A responsabilidade pela informação, o conselho e a recomendação, na fase

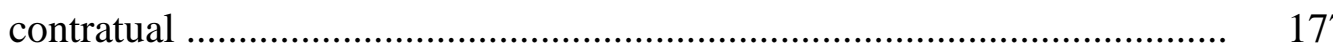

4.4 A responsabilidade pela informação, o conselho e a recomendação, na fase pós-contratual.................................................................................... 195

4.5 A responsabilidade pela informação, o conselho e a recomendação, nas relações intersubjetivas dissociadas do contrato

5. Considerações finais.

6. Conclusão 


\section{INTRODUÇÃO}

A radical evolução das relações humanas, o incrível avanço da tecnologia e a dinâmica das relações comerciais acabaram por tornar imperiosa a especialização da mão de obra e da prestação de serviços, criando, por conseguinte, profissionais altamente especializados, detentores de informações técnicas essenciais ao cotidiano de qualquer pessoa.

O indivíduo que vive na sociedade de hoje necessita de uma série de informações para poder praticar as tarefas mais comezinhas do dia a dia. Desde a singela compra de gêneros alimentícios em um supermercado até a busca de maior rentabilidade à sua aplicação financeira demandam o conhecimento de uma plêiade bastante diversificada de fatores capazes de influenciar o seu processo de escolha.

De fato, recente é o exemplo da fraude ocorrida na produção e comercialização de leite, em que os responsáveis por sua adulteração adicionavam soda cáustica ao produto final, para ter aumentado o seu volume e expandida a sua data de validade. $^{1}$

Mais recente e não menos estarrecedor é o exemplo da crise financeira mundial, em que se descobre que os administradores de diversos fundos de investimento, espalhados pelo mundo afora, sonegavam informações acerca de suas carteiras, quando não criavam informações fictícias, apenas para terem aumentado os seus bônus de final de ano, ${ }^{2}$ resultando em um debacle de proporções ainda

1 “18 pessoas são denunciadas por fraude em leite. Suspeitos adicionaram soda cáustica ao produto, diz Ministério Público Federal. Adulteração, desvendada pela Polícia Federal em outubro de 2007, ocorria para aumentar o volume e o prazo de validade do leite" (Renata Baptista, jornal Folha de S.Paulo, 20 maio 2008, seção Cotidiano).

2 Sobre o tema, leia-se o emblemático exemplo das gigantes do crédito imobiliário norte-americano, as empresas Fannie Mae e Freddie Mac: "Em 2004, a Fannie Mae foi acusada de maquiar suas contas com o objetivo de gerar bônus mais vantajosos para seus executivos. Os três principais diretores foram levados a pedir demissão e a pagar uma multa de US\$ 100 milhões. Em 2006, a Freddie Mac foi multada em US\$ 3,8 milhões por lobby ilegal junto a membros da Câmara dos Representantes encarregados de supervisionar suas atividades. A situação híbrida das duas gigantes do crédito imobiliário - empresas públicas e privadas ao mesmo tempo - permitia a elas jogar com as regras de ambos os setores de atividade. Encarregadas de uma missão social - permitir ao maior número de pessoas o acesso à propriedade imobiliária -, as duas financeiras buscavam, no entanto, a 
imprevisíveis, mas que já causou enormes estragos em instituições financeiras, fornecedoras de crédito, montadoras, empresas de gêneros alimentícios etc., prometendo criar uma onda ainda maior de prejuízos e levar o mundo a um prolongado período de recessão.

As informações prestadas por profissionais especializados, economistas de alto gabarito e renomados analistas financeiros ao longo dos últimos anos demonstraram-se desencontradas e incapazes de prever as consequências deletérias da falta de fiscalização e controle mínimo do chamado mercado, esse ente desconhecido, mas com poder para definir o futuro de nações. ${ }^{3}$

Neste contexto, verifica-se que a informação constitui bem de inegável valor para um mundo globalizado e em constante transformação. Do sujeito que vai consultarse com um médico àquele que pretende comprar um computador, do casal que contrata um arquiteto para realizar o sonho de construir seu lar àquele que consulta o advogado para pôr fim à sociedade conjugal, todos demandam por informações especializadas, cujas deficiências na prestação podem constituir fonte de danos a exigir sua reparação.

Por conseguinte, faz-se necessária a democratização do acesso à informação e ao conhecimento, a fim de que se possa promover a construção de uma sociedade mais justa, equânime e solidária, ideal perseguido pela República Federativa do Brasil.

Essa troca de informações, característica do trato social, encontra-se alicerçada sobre um ideal de confiança essencial para o desenvolvimento das relações intersubjetivas e da vida em sociedade.

maximização dos ganhos dos seus acionistas e, sobretudo, dos seus diretores. Os presidentes da Fannie Mae e da Freddie Mac recebiam salários de US\$ 70 milhões por ano, cada um" (Ibrahim Warde, Fannie Mae e Freddie Mac vão para o brejo, artigo publicado na edição mensal do jornal $L e$ Monde Diplomatique, out. 2008).

3 “O mercado é, até hoje, um ser desconhecido. Necessitamos de uma teoria constitucional do mercado. Eu sustento que o mercado não é o sentido último do Estado constitucional. A sociedade aberta não é um jogo de ganhos econômicos. Uma república se baseia no trabalho, como diz a Constituição italiana de 1947, se fundamenta na dignidade humana, descansa sobre a cultura, mas não se baseia nos mercados" (Peter Häberle, Conversas acadêmicas com Peter Häberle, tradução de Carlos dos Santos Almeida, São Paulo: Saraiva, 2009, p. 32). 
O homem de hoje confia, desde o momento em que acorda até o momento em que vai dormir e no momento em que está dormindo, pois crê na informação de que o seu telhado não irá ruir às primeiras chuvas.

No entanto, a difusão da informação também pode gerar danos, violando essa confiança essencial para o convívio social, quando, desgarrada de sua função constitucional, ofender o princípio da dignidade da pessoa humana e os direitos fundamentais do cidadão ou quando, divulgada de forma negligente, lesar o patrimônio de outrem.

O presente trabalho, desenvolvido a partir de compilação doutrinária e jurisprudencial, objetiva proceder à análise e discussão da responsabilidade daqueles que prestam informações a terceiros, aconselham-nos ou apenas apresentam recomendações a outrem, particularmente no que se refere às relações entre particulares.

O exercício potencialmente danoso do dever de informar, o uso da informação e do conhecimento como forma de concentração e de manutenção de poder, a descurada transmissão de um parecer ou de um simples esclarecimento e os prejuízos daí decorrentes justificam o estudo mais detalhado deste tema.

De fato, com o advento do Código Civil de 2002 operou-se uma importante reforma no direito civil legislado, notadamente no âmbito da responsabilidade civil.

Por conseguinte, pretende-se apresentar os fundamentos da liberdade e do dever de informar, de dar conselhos ou recomendações, em seus diversos espectros, especialmente no que tange aos seus efeitos e à responsabilidade daquele que os presta.

Além disso, almeja-se demonstrar que a confiança constitui valor fundamental de nosso ordenamento jurídico, alicerce necessário para o desenvolvimento das relações intersubjetivas e fonte de um dever ético de conduta, cuja violação gera a obrigação de se reparar os danos que dela decorram. 
Assim, nesta tese sustentaremos a existência de uma responsabilidade pela confiança, não como uma terceira via que seria somada à responsabilidade contratual $\mathrm{e}$ extracontratual, mas como fonte da obrigação de reparar danos, afirmando que a confiança representa um dos valores fundantes da responsabilidade civil, enquanto base valorativa fundamental da ordem jurídica.

Essa base fundada na confiança será essencial para que se possa chegar às respostas perseguidas pelo estudo da responsabilidade decorrente das informações, conselhos e recomendações em nosso ordenamento.

No entanto, a discussão acerca da informação, bem como do conselho e da recomendação, pode se alargar pelos mais diversos e distantes caminhos, razão pela qual é fundamental a delimitação do tema a que se propõe o presente trabalho.

Por conseguinte, o presente estudo se propõe a proceder à análise da responsabilidade pelos danos causados nas relações entre particulares, em virtude de conselhos, recomendações ou informações que acabem por formar convicção do seu destinatário e que, por essa razão, possuam um potencial danoso efetivo, seja no momento da formação do contrato, de sua execução ou conclusão, e até mesmo na fase pós-contratual.

Contudo, exclui-se do âmbito do presente trabalho a digressão acerca do dever de prestar informações sobre um produto a ser colocado no mercado de consumo - o dever de informar do fabricante -, assim como aquelas apresentadas em peças publicitárias.

Excluem-se também as informações prestadas nos chamados contratos de massa, característicos das relações consumeristas, eis que a presente tese se propõe a proceder à análise dos efeitos das recomendações, conselhos ou informações no âmbito das relações entre particulares, disciplinadas, principalmente, pelo Código Civil brasileiro. 
Isso porque o tema atinente ao dever de informação nas relações de consumo representa, por si só, objeto para outra tese, o que, aliás, já foi bastante discutido nos meios acadêmicos nacionais.

É claro que não se pode, simplesmente, isolar as relações privadas regidas pelo Código Civil das demais, como se as relações intersubjetivas fossem exatas e estanques, o que demandará o recurso ao Código de Defesa do Consumidor para a solução de alguns casos aqui analisados, tais como a responsabilidade de contadores e advogados, pelos conselhos, informações e recomendações fornecidos aos clientes.

Saliente-se, contudo, que não se pretende analisar o dever de informação do fornecedor de produtos, mas somente o prestador de serviços e em alguns casos relevantes, consoante restará evidenciado.

Afora esses casos, o objeto de análise concentra-se nas relações privadas que não constituem uma relação de consumo e nos efeitos decorrentes da troca de informações, conselhos ou recomendações entre distintos sujeitos de direito.

Para tanto, faz-se mister a digressão acerca dos novos paradigmas da responsabilidade civil em nosso ordenamento jurídico, questão que é tratada no primeiro capítulo desta tese.

Nesse capítulo procede-se à análise dos efeitos da revolução tecnológica e de seus consequentes riscos no âmbito da responsabilidade civil, para, ao depois, discorrer-se sobre a sua evolução em nosso ordenamento, começando pelo regime de responsabilidade extracontratual e pelo seu caminho da culpa ao risco, para, posteriormente, fazer-se a digressão acerca dos novos princípios contratuais e a sua importância para as mudanças perpetradas na responsabilidade decorrente do contrato.

Já em um segundo capítulo requesta-se discutir especificamente sobre a teoria da confiança e a sua importância para o desenvolvimento do tema em questão, bem como realizar uma digressão sobre o negócio jurídico e as diversas teorias a ele atinentes, para, ao final, discorrer-se sobre o princípio da boa-fé objetiva e seus deveres 
anexos, temas essenciais para o desenvolvimento do presente estudo, em especial no que tange ao dever de informar.

No terceiro capítulo concentra-se uma das questões centrais da tese, consistente nos fundamentos de uma responsabilidade pela confiança em nosso ordenamento. Para o seu desenvolvimento partimos da premissa fundamental caracterizada pelo respeito à lógica de nosso sistema, para chegar a uma solução que se apresente em consonância com a ordem jurídica pátria.

Para tanto, parte-se da análise da base axiológica insculpida pela Constituição Federal de 1988, para depois se discutir sobre a eficácia dos direitos fundamentais em nosso ordenamento e a forma como os princípios constitucionais irradiam-se nas relações entre particulares, discorrendo sobre a diferença entre princípios e regras, bem como acerca das cláusulas gerais e dos conceitos indeterminados.

Tudo isso para formar uma base conceitual sólida capaz de permitir a defesa da existência de uma responsabilidade pela confiança em nosso ordenamento jurídico, apresentando os seus fundamentos.

No quarto capítulo desenvolve-se a outra questão fulcral da tese, o tema de nossa investigação, mediante a apresentação de conceitos para a informação, o conselho e a recomendação, investigando-se sua amplitude. Nele se insere a discussão acerca da questão atinente à responsabilidade pelas informações, conselhos ou recomendações prestados no momento da formação do contrato, bem como na fase contratual propriamente dita, e na fase pós-contratual.

No quinto capítulo apresentam-se algumas considerações finais, a fim de se consolidar a digressão acerca do tema estudado e a solução proposta, comparando-a inclusive com a de outros ordenamentos, para no sexto e derradeiro capítulo apresentar a conclusão desta tese. 


\section{NOVOS PARADIGMAS \\ DA RESPONSABILIDADE CIVIL}

\subsection{A evolução tecnológica e os seus riscos}

O avanço da tecnologia, decorrente da radical revolução no campo das telecomunicações e da informática, impulsionou a produção industrial e o comércio internacional, acelerando a velocidade na transmissão da informação e aumentando, por conseguinte, a complexidade das relações intersubjetivas e de seus respectivos efeitos, bem como a dinâmica das relações entre diferentes Estados. ${ }^{4}$

A transformação radical da sociedade pós-moderna produziu reflexos em todos os aspectos decorrentes das relações humanas. A globalização aumentou a competição internacional, determinando uma irreversível mudança na estrutura econômica mundial, tornando indispensáveis o acesso à informação e ao conhecimento. ${ }^{5}$

Nesse diapasão, as profundas transformações em nossa sociedade, decorrentes da evolução do pensamento, da liberalização dos costumes, do incremento e

4 “A globalização do trânsito e da comunicação, da produção econômica e de seu financiamento, da transferência de tecnologia e de poderio bélico, especialmente dos riscos militares e ecológicos, tudo isso nos coloca em face de problemas que não se podem mais resolver no âmbito dos Estados nacionais, nem pela via natural do acordo entre Estados soberanos" (Jürgen Habermas, A inclusão do outro: estudos de teoria política, tradução de George Sperber, Paulo Astor Soethe e Milton Camargo Mota, São Paulo: Loyola, 2002, p. 129).

5 "A grande ruptura que ocorreu no fim do século $\mathrm{XX}$ consiste na criação, no reconhecimento e na generalização, no mundo inteiro, de uma nova economia que modificou profundamente a estrutura social e ensejou, de fato, a criação da sociedade de massas. Embora houvesse uma transformação gradual, que se fez sentir a partir do fim da Segunda Guerra Mundial, os seus efeitos passaram a ocorrer em ritmo mais intenso nos últimos dez anos, em todos os países, baseando-se no enorme e rápido desenvolvimento tecnológico, que gerou maior competição no mundo inteiro, mas também na globalização e na desmaterialização parcial da riqueza, com reflexos em todos os aspectos da sociedade e, inclusive, no direito" (Jeremy Rifkin, The age of access, New York: Jeremy P. Tacher e G. P. Putnam's Sons, 2002; apud Arnoldo Wald, A evolução do contrato no terceiro milênio e o novo Código Civil, in: Arruda Alvim; Joaquim Portes de Cerqueira César; Roberto Rosas (Coord.), Aspectos controvertidos do novo Código Civil: escritos em homenagem ao Ministro José Carlos Moreira Alves, São Paulo: RT, 2003, p. 59). 
da complexidade ${ }^{6}$ das práticas comerciais e laborais, da dinâmica e volátil estruturação econômica mundial e, especialmente, da necessidade de se garantir uma existência digna ao ser humano, tornaram imperioso o repensar do direito, em virtude da nova e intrincada realidade social.

De fato, o estudo do direito e, especialmente, do direito privado, não pode prescindir da análise da sociedade "na sua historicidade local e universal, de maneira a permitir a individualização do papel e do significado da juridicidade na unidade e na complexidade do fenômeno social", consoante observa Pietro Perlingieri. ${ }^{7}$

Neste panorama, merece destaque a questão atinente à reparação do dano decorrente do fato social e das relações interpessoais, pois, conforme já afirmava José de Aguiar Dias, "a manifestação da vontade humana traz em si o problema da responsabilidade civil". ${ }^{8}$

Isso porque a transmudação da realidade social, em seus inúmeros aspectos, propicia, como consequência, a profusão dos danos decorrentes do fato social, com o aumento do número de vítimas demandando a sua reparação.

Nos dias de hoje, como bem salienta Teresa Ancona Lopez, os direitos da pessoa encontram-se ameaçados, terrivelmente, não apenas pelo "assustador progresso tecnológico, mas, principalmente, pela falta de solidariedade e respeito dentro da sociedade moderna, caracterizada, infelizmente, por todos os tipos de violência". 9

Como corolário dessa nova realidade, faz-se necessária a adequação dos fundamentos da responsabilidade civil à realidade pós-moderna, com vistas à promoção

\footnotetext{
6 "A palavra-chave de nossa época é, de fato, a complexidade. Trata-se de uma palavra com a qual se alude a fenômenos múltiplos e a diversos níveis de análise, mas que certamente representa 'a crise de toda explicação simples do mundo' e dos processos sociais, precludendo toda possibilidade de reduzir a representação de fato e de acontecimentos naturais e sociais a esquemas conceituais confiados a uma lógica linear" (Pietro Barcellona, O egoísmo maduro e a insensatez do capital, tradução de Sebastião José Roque, São Paulo: Ícone, 1995).

7 Pietro Perlingieri, Perfis do direito civil: introdução ao direito civil constitucional, tradução de Maria Cristina De Cicco, Rio de Janeiro: Renovar, 1999, p. 1.

$8 \quad$ José de Aguiar Dias, Da responsabilidade civil, 5. ed., Rio de Janeiro: Forense, 1973, p. 7.

9 Teresa Ancona Lopez, O dano estético, 3. ed., São Paulo, RT, 2004, p. 17.
} 
do atendimento às vítimas de danos, pois o desenvolvimento das relações humanas deve estar centrado em um ideal de excelência, fundamentado pelo respeito à individualidade, pela consideração recíproca e por princípios de equidade, de forma a possibilitar a consecução do bem-estar social e da plenitude da vida. ${ }^{10}$

A violação dos direitos da personalidade, bem como dos direitos patrimoniais, e os danos daí decorrentes servem de supedâneo para a constante evolução do instituto da responsabilidade e para a transformação da realidade jurídico-normativa, em busca da tutela dos interesses das vítimas, assegurando-lhes a efetiva reparação, enquanto objetivo fundamental.

Consoante observa Giselda Maria Fernandes Novaes Hironaka, ${ }^{11}$ "poucos institutos jurídicos evoluem mais do que a responsabilidade civil". Para ela, sua importância ganha relevo e se agiganta em decorrência dessa evolução, "dessa mutabilidade constante, dessa movimentação eterna no sentido de ser alcançado seu desiderato maior, que é exatamente o pronto-atendimento às vítimas de danos pela atribuição, a alguém, do dever de indenizá-los". ${ }^{2}$

10 Alertando para os efeitos decorrentes dos avanços tecnológicos e suas consequências no campo da ética e da responsabilidade, Hans Jonas assim assevera: "A técnica moderna introduziu ações de uma tal ordem inédita de grandeza, com tais novos objetos e consequiências que a moldura da ética antiga não consegue mais enquadrá-las. O coro da Antígona sobre o 'Ungeheure', o fantástico poder do homem, soaria bem diferente hoje, assumindo a palavra 'fantástico' um outro sentido; e não mais bastaria a advertência aos indivíduos para que respeitassem as leis. Também já há muito não estão mais aqui os deuses, cujos direitos reconhecidos poderiam contrapor-se às fantásticas ações humanas. Decerto que as antigas prescrições da ética 'do próximo' - as prescrições da justiça, da misericórdia, da honradez etc. - ainda são válidas, em sua imediaticidade íntima, para a esfera mais próxima, quotidiana, da interação humana. Mas essa esfera torna-se ensombrecida pelo crescente domínio do fazer coletivo, no qual ator, ação e efeito não são mais os mesmos da esfera próxima. Isso impõe à ética, pela enormidade de suas forças, uma nova dimensão, nunca antes sonhada de responsabilidade" ( $O$ princípio responsabilidade, ensaio de uma ética para a civilização tecnológica, tradução do original alemão de Marijane Lisboa e Luiz Barros Montez, Rio de Janeiro: Contraponto, PUC-Rio, 2006, p. 39).

11 Giselda Maria Fernandes Novaes Hironaka, Responsabilidade pressuposta, Belo Horizonte: Del Rey, 2005, p. 2.

12 Ressaltando a influência da realidade social sobre a responsabilidade, José Jairo Gomes assim assevera: "O instituto da responsabilidade civil é substancialmente dinâmico, sofrendo acentuada influência social e humana. Pode ser comparado a um porto, no qual diversos segmentos do Direito se ancoram, daí resultando variegados tipos de responsabilidade, a exemplo da civil, penal, comercial, trabalhista, tributária, política e eleitoral. Dada essa multifária atuação, tal instituto tem evoluído e se transformado ao longo da história para se adaptar aos novos modelos sociais e às novas necessidades impostas pela cambiante realidade cultural" (Responsabilidade civil e eticidade, Belo Horizonte: Del Rey, 2005, p. 220). 
Por essas razões, é possível verificar que a responsabilidade exerce, e sempre exerceu, papel fundamental nas relações humanas, acentuado, nos dias de hoje, pela velocidade dos avanços tecnológicos, pelo uso generalizado de novos equipamentos e pelo consequente aumento da competitividade decorrente da globalização.

Sob esse prisma, as consequências danosas provenientes dos atos de um indivíduo produzirão efeitos sobre outros, e é preciso que a sociedade, como protetora de todos os seus membros, imponha ao ofensor o dever de reparar os danos causados, evitando-se que a vítima permaneça irressarcida.

Assim, a tutela da dignidade da pessoa humana, sua promoção e a consequente proteção aos direitos da personalidade, que constituem a base axiológica de nosso ordenamento jurídico, não podem permitir a ocorrência de um dano injusto, ainda que proveniente de um ato lícito.

Nesse sentido, Giselda Maria Fernandes Novaes Hironaka ressalva a questão emblemática da responsabilidade civil na era da pós-modernidade, ao demonstrar a tendência atual de revolta contra as inúmeras construções jurisprudenciais e doutrinárias, que visaram, primordialmente "dar menos à interpretação dos textos legais, no sentido de favorecimento do direito das vítimas, para dar mais a essa interpretação que ocorreu no sentido de melhor favorecer o interesse do demandado". ${ }^{13}$

Dessa forma, torna-se imperiosa a necessidade de se promover o efetivo socorro à vítima, liberando-se das amarras representadas pela imposição da prova da culpa ou dolo do agente causador do dano, abrindo-se o caminho para a pacificação social e a concretização dos ideais de justiça e de solidariedade.

13 Giselda Maria Fernandes Novaes Hironaka, Responsabilidade pressuposta - Evolução dos fundamentos e de paradigmas da responsabilidade civil na contemporaneidade, in: Mario Luiz Delgado e Jones Figueiredo Alves (Coord.), Novo Código Civil: questões controvertidas responsabilidade civil, São Paulo: Método, 2006, v. 5, p. 198. 
Jürgen Habermas salienta que "se interpretarmos a justiça como aquilo que é igualmente bom para todos, o 'bem' contido na moral constitui uma ponte entre a justiça e a solidariedade". ${ }^{14}$ Isso porque, para se entender a justiça universalisticamente, exige-se "que uma pessoa responda pelo estranho, que formou a sua identidade em circunstâncias de vida totalmente diferentes e entende-se a si mesmo à luz de tradições que não são as próprias". ${ }^{15}$

Mais adiante, o mestre da Escola de Frankfurt ressalta a relevância da construção de uma ponte entre a justiça e a solidariedade, ao afirmar que, "expresso de modo aristotélico, em toda comunidade concreta está esboçada a comunidade moral, por assim dizer, como seu 'melhor eu'". 16

E são os indivíduos integrantes dessa comunidade que "esperam uns dos outros uma igualdade de tratamento, que parte do princípio de que cada pessoa considere cada uma das outras como 'um dos nossos'. A partir dessa perspectiva, justiça significa simultaneamente solidariedade". ${ }^{17}$

Assim, para a consecução de uma ordem jurídica justa e solidária, a valoração do interesse da vítima e a tutela de sua dignidade constituem um dos pilares desse novo sistema de responsabilidade civil.

Neste sentido, Pietro Perlingieri ressalva a necessidade de entender a questão moral como efetivo respeito à dignidade da vida de cada homem e, por conseguinte, como valor superior a qualquer razão política da organização da vida em comum, para que, dessa forma, "seja a resposta ao centro do debate na doutrina e no Foro, como única indicação idônea a impedir a vitória de um direito sem justiça". 18

\footnotetext{
14 Jürgen Habermas, A inclusão do outro: estudos de teoria política, cit., p. 43.

15 Idem, ibidem, p. 43.

16 Idem, p. 44.

17 Idem, p. 44.

18 Pietro Perlingieri, Perfis do direito civil: introdução ao direito civil constitucional, cit., p. 23.
} 
A ideia de justiça, destarte, encontra-se diretamente relacionada ao desenvolvimento das relações humanas, pois o sistema social processa desapontamentos e impõe expectativas normativas.

Nesse diapasão, assinala José Jairo Gomes que a ideia de justiça impõe a distribuição equânime de tarefas sociais, exigindo, por outro lado, que cada pessoa suporte as consequências adversas de seus comportamentos, "aí incluídos os danos com a violação, por um sujeito, da esfera jurídica de outro e, sobretudo, com a infração a dever a todos imposto pelo sistema jurídico". ${ }^{19}$

Contudo, não é só na reparação do dano causado à vítima que se encontram os alicerces desse novo sistema, mas também na prevenção da ocorrência desses danos, abrindo-se um largo campo para a aplicação da responsabilidade preventiva. ${ }^{20}$

Sobre o tema, ensina Teresa Ancona Lopez que, com a consagração do princípio da precaução, consolida-se "uma bipartição da responsabilidade civil em compensatória (reparação integral) e responsabilidade preventiva (precaução e prevenção)". ${ }^{21}$

Segundo seus ensinamentos, enquanto na responsabilidade compensatória faz-se necessária a existência do dano como pressuposto para sua efetivação, na preventiva ocorre "a imputação da responsabilidade pela exposição de terceiros a riscos que podem se tornar irreversíveis. Ou seja, é a responsabilidade sem dano".22

De fato, a sociedade hodierna encontra-se intrinsecamente ligada à ideia de risco, enquanto efeito dos perigos criados pelos avanços tecnológicos e pelo ritmo desenfreado e desordenado das atividades empreendidas pelo homem em seus mais diversos e outrora inimagináveis espectros.

\footnotetext{
19 José Jairo Gomes, Responsabilidade civil e eticidade, cit., p. 222.

20 Sobre o tema, confira-se a brilhante tese para Concurso de Professor Titular de Direito Civil da Faculdade de Direito da Universidade de São Paulo da autora Teresa Ancona Lopez: Princípio da precaução e evolução da responsabilidade civil, 2008.

21 Teresa Ancona Lopez. Princípio da precaução e evolução da responsabilidade civil, cit., p. 225.

22 Idem, ibidem, p. 225.
} 
Ulrich Beck afirma a existência de uma verdadeira sociedade de risco, alertando para os perigos da sociedade industrial quando suas instituições "tornam-se os produtores e legitimadores das ameaças que não conseguem controlar". ${ }^{23}$

Sob esse prisma ganha relevo a discussão atinente à responsabilidade civil da pessoa jurídica, eis que a intensa transformação de nossa realidade social apresenta como propulsor o vertiginoso desenvolvimento das técnicas de produção industrial, das atividades comerciais, bem como da tecnologia, patrocinados, em sua maioria, pela evolução da empresa e do grupo societário, em suas distintas formas de estruturação.

De início, houve aqueles que defendessem a tese de que a pessoa jurídica não poderia ser responsabilizada por danos que decorressem do exercício de suas atividades, sustentando que, em virtude da responsabilidade aquiliana fundar-se na culpa do responsável - como princípio geral -, as pessoas jurídicas seriam insuscetíveis de culpa, posto não possuírem consciência, vontade e ação própria. Desse modo, só existiria a culpa de seus órgãos e de seus agentes. ${ }^{24}$

Contra essa argumentação insurgiu-se, em peso, o pensamento doutrinário, que pode ser traduzido pelas palavras de Manoel Domingues de Andrade, ao ressalvar a autorização legal conferida à pessoa jurídica para o exercício de sua atividade, através de seus respectivos órgãos ou agentes, buscando auferir os benefícios daí decorrentes, impondo-se que deva também "suportar no seu patrimônio - na sua economia - os prejuízos que ela ocasiona a terceiros". ${ }^{25}$

Por essa razão, deve a pessoa jurídica sofrer as consequências in damnosis, se tal atividade lhe aproveita in utilibus. ${ }^{26}$

23 Ulrich Beck, A reinvenção da política: rumo a uma teoria da modernização reflexiva, in: Anthony Giddens; Scott Lash, Modernização reflexiva, tradução de Magda Lopes, São Paulo: Unesp, 1997, p. 15-16.

24 Manuel A. Domingues de Andrade, Teoria geral da relação jurídica, v. 1, Sujeito e objecto, Coimbra: Almedina, 2003, p. 132.

25 Idem, ibidem, p. 133-134.

26 Idem, p. 133-134. 
Nos dias de hoje, como é notório, encontra-se superada a discussão acerca da possibilidade de se imputar responsabilidade à pessoa jurídica, independentemente da responsabilidade de seus órgãos ou agentes, eis que a sua atividade e a consequente dinâmica laborativa constituem elementos potencialmente fixadores de risco para as pessoas envolvidas (consumidores, trabalhadores, fornecedores etc.), tornando necessária a imposição de limites para a sua atuação.

No entanto, permanece latente a discussão relativa à extensão da responsabilidade civil das pessoas jurídicas no contexto da pós-modernidade, em que a tutela do interesse da vítima e a busca da restauração da igualdade destruída pela ocorrência do dano constituem o objetivo precípuo a ser alcançado para a efetivação dos princípios da solidariedade social, da cooperação e da dignidade da pessoa humana.

O incremento do potencial danoso decorrente do avanço tecnológico característico da sociedade globalizada impõe a necessidade de se prevenirem os riscos criados pela intrincada estrutura social dos tempos de pós-modernidade, ${ }^{27}$ o que evidencia a necessidade de se buscar soluções em modelos distintos do quadro institucional tradicional. ${ }^{28}$

Nesse contexto insere-se a questão relativa à responsabilidade daqueles que prestam informações, recomendações ou advertências, posto que o conhecimento e as suas diversas formas de difusão representam um bem de inegável valor na atual sociedade de risco em que vivemos.

O presente estudo tem como objeto a análise da responsabilidade civil daqueles que prestam informações, recomendações, advertências ou, tão somente,

27 "Sob o primeiro aspecto, a evolução tecnológica assegurou aos particulares um potencial danoso que, antes, só se vislumbrava no Estado. Danos de abrangência significativa que somente podiam ser produzidos pela máquina pública derivam, cada vez mais, da atuação empresarial e também do comportamento adotado por indivíduos comuns" (Anderson Schreiber, Novos paradigmas da responsabilidade civil. Da erosão dos filtros da reparação à diluição dos danos, São Paulo: Atlas, 2007, p. 3).

28 Nesse sentido, Stefano Rodotà ressalva "a inadequação das tradicionais definições jurídicoinstitucionais diante dos novos problemas impostos pela realidade dos sistemas informativos atuais" (A vida na sociedade da vigilância. A privacidade hoje, organização, seleção e apresentação de Maria Celina Bodan de Moraes, Rio de Janeiro: Renovar, 2008, p. 25). 
conselhos, no âmbito de uma sociedade altamente informatizada e extremamente competitiva, em que os indivíduos se encontram cada vez mais cônscios de seus direitos e prerrogativas. ${ }^{29}$

Por conseguinte, aumenta-se o potencial danoso decorrente das relações intersubjetivas, ao mesmo tempo em que ocorre um considerável acréscimo no número de pleitos exigindo a reparação de danos. Em contrapartida, surge uma torrente de ações indenizatórias sem fundamento ou substrato jurídico, na esteira do que se convencionou chamar de indústria do dano.

Alertando para o perigo decorrente do desenfreado alargamento no âmbito da responsabilidade civil, Anderson Schreiber adverte para o fato de que a "ampliação excessiva da responsabilização, em seu formato atual, povoa os pensamentos de dez entre dez estudiosos, acertadamente apreensivos com o aumento da litigiosidade e da vitimização da convivência social". ${ }^{30}$

A busca pelo equilíbrio entre a necessidade de se encontrar novas soluções para os problemas decorrentes da sociedade de risco, distante do modelo institucional tradicional, e o cuidado para não se estimular uma desmesurada e não fundamentada demanda indenizatória, ${ }^{31}$ constituirão a mola mestra do presente trabalho, sem, no entanto, se descurar da nova ordem civil-constitucional, dos novos paradigmas aqui ressalvados e da evolução do instituto operada no direito civil pátrio.

Outrossim, há que se ressaltar que as informações, assim como os conselhos e as recomendações, permeiam-se por todas as relações entre particulares, seja no

29 "De outra parte, também os interesses lesados se expandiram consideravelmente. O reconhecimento da normatividade dos princípios constitucionais e a definitiva consagração da tutela de interesses existenciais e coletivos, conquistas da ciência jurídica contemporânea, ampliaram imensamente o objeto protegido pelo direito em face da atuação lesiva" (Anderson Schreiber, Novos paradigmas da responsabilidade civil. Da erosão dos filtros da reparação à diluição dos danos, cit., p. 4).

$30 \quad$ Idem, ibidem, p. 4.

31 Consoante ressalva Anderson Schreiber, "observa-se atualmente uma inundação de novos danos ressarcíveis, nada criteriosa, capaz de pôr em risco - em vez de proteger - os próprios fundamentos éticos e sociais que deram origem à extensão da responsabilização. Diante da premissa, autoexplicativa, de que nem todo dano pode ou deve ser reparado, o cerne do direito da responsabilidade civil, passou a ser o do estabelecimento do critério - ou dos critérios - que justificam a transferência a outrem do prejuízo sofrido pela vítima em virtude da lesão a um bem jurídico seu” (ibidem, p. 3). 
âmbito do contrato, seja em situações cotidianas que se encontram dissociadas de uma relação contratual.

Por essa razão, torna-se necessário proceder à análise da atual situação de nosso ordenamento jurídico no que tange às recentes alterações operadas no âmbito da responsabilidade extracontratual, especialmente com o advento do Código Civil de 2002, bem como no que pertine à responsabilidade decorrente do inadimplemento de obrigações contratuais, em que já existe uma relação jurídica entre as partes, a fim de se delimitar o campo de desenvolvimento desta tese.

Não se desconhece a controvérsia acerca da dicotomia entre responsabilidade contratual e extracontratual, eis que os monistas, adeptos da também chamada teoria unitária, repudiam a sua existência. No entanto, o ordenamento jurídico brasileiro acolheu a teoria dualista ou clássica, distinguindo a responsabilidade decorrente de uma relação jurídica contratual daquela em que o dever jurídico violado está previsto na ordem jurídica ou na lei e não no contrato.

Nos ordenamentos que adotam a teoria clássica a distinção torna-se relevante em virtude de suas consequências e do tratamento legal diferenciado dado a cada uma delas, como é o caso, por exemplo, do dolo ou da culpa presumidos, na hipótese de responsabilidade contratual, ao passo que, em regra, devam ser comprovados na extracontratual.

Neste sentido, vejamos os exemplos do sistema italiano e argentino, bastante próximos do brasileiro, a fim de evitarmos a digressão exaustiva do direito comparado, afastando-nos do cerne de nosso estudo. ${ }^{32}$

Comentando o sistema italiano, Guido Alpa observa que do ponto de vista formal é bastante fácil praticar a distinção entre responsabilidade contratual e responsabilidade extracontratual, desde o momento em que a primeira nasce do

32 Para uma análise mais aprofundada da distinção entre a responsabilidade contratual e a extracontratual no direito comparado confira-se a obra de Enéas Costa Garcia, Responsabilidade pré e pós-contratual à luz da boa-fé, São Paulo: Juarez de Oliveira, 2003, p. 264-267. 
descumprimento de uma obrigação, enquanto a segunda nasce do cometimento de um ato ilícito. No entanto, adverte para o que chama de uma distinção arbitrária, pois pode surgir uma responsabilidade de natureza contratual de relações pré-contratuais; e inexata, posto que a distinção na atualidade se esvaziou, eis que a obrigação contratual nos dias de hoje tende a ser considerada como uma estrutura complexa, que, por conseguinte, envolve obrigações acessórias. Já a responsabilidade extracontratual tende a envolver fenômenos contratuais como ocorre na responsabilidade civil por atividades negociais. $^{33}$

Não obstante, o mestre italiano elenca o que considera as principais diferenças entre ambas: a) o fato que constitui o fundamento da responsabilidade contratual é o comportamento daquele que não cumpre o contrato, enquanto na extracontratual corresponde ao do autor do ato ilícito; b) a irrelevância do fato das coisas na responsabilidade contratual e a sua relevância na aquiliana; c) a responsabilidade pelo fato de terceiros possui uma interpretação extensiva na responsabilidade contratual e uma interpretação restritiva no campo extracontratual; d) na responsabilidade contratual se responde apenas pelos danos previsíveis, o que não ocorre na delitual; e) considera-se válida a cláusula de limitação da responsabilidade contratual, o que não ocorre na extracontratual; f) os juros moratórios são legais na responsabilidade decorrente do contrato e liquidados pela via equitativa se esta não decorre de um contrato. ${ }^{34}$

Situação semelhante se verifica no sistema argentino, em que Ricardo Lorenzetti lista como principais elementos diferenciadores da responsabilidade contratual e da extracontratual: a) a antijuridicidade, que na responsabilidade aquiliana se configura pela contradição ao dever genérico de não causar dano a outrem, enquanto na contratual surge por violação a uma obrigação preexistente e de origem convencional. Como consequência da antijuridicidade, haveria que se ressaltar que o contrato é criação da autonomia privada, e, portanto, existe um critério particular para a administração dos riscos, ao passo que na responsabilidade extracontratual só ocorrem

Guido Alpa, Responsabilidad civil y daño. Lineamentos y cuestiones, tradução de Juan Espinoza Espinoza, Lima: Caceta Jurídica, 2001, p. 27.

34 Idem, ibidem, p. 28. 
valorações coletivas. Além disso, a responsabilidade contratual foi desenhada para garantir a colaboração alheia buscada através do contrato, enquanto na aquiliana se pretende evitar a invasão ilícita na esfera protegida. Outrossim, a responsabilidade contratual possui enfoque na proteção do crédito com relação às violações causadas pelo devedor, e no âmbito aquiliano também se pode proteger o crédito, mas relacionado aos ataques de terceiros e não do devedor. ${ }^{35}$

Além da antijuridicidade, Lorenzetti aponta como elementos de distinção entre as duas responsabilidades: b) a constituição em mora, pois em alguns contratos deve haver a interpelação do devedor, sem embargo de existirem hipóteses em que a constituição seja imediata, a exemplo do que ocorre no âmbito extracontratual; c) a causalidade, eis que na responsabilidade aquiliana se responde de forma plena e integral pelas consequências imediatas e mediatas previsíveis, enquanto contratualmente se responde pelas consequências imediatas e necessárias do inadimplemento; d) o dano, posto no âmbito extracontratual vigorar o princípio da reparação integral, ressarcindo-se sempre o dano moral e no campo dos contratos o juiz poderá repará-lo tendo em vista a índole do fato causador do dano; e) a prescrição, em que existem prazos diferenciados para ambas; f) a solidariedade, que nos contratos deve estar pactuada ou prevista em lei, embora extracontratualmente exista uma ampla tendência de impor a solidariedade como forma de ampliar a segurança do crédito; g) a competência, em que o local do ilícito é aquele em que devem ser propostas as ações de reparação de danos extracontratuais, e o lugar da celebração do contrato ou o eleito pelas partes é o competente na hipótese contratual; h) a capacidade contratual distinta da capacidade delitual. ${ }^{36}$

No ordenamento jurídico brasileiro a responsabilidade extracontratual está prevista expressamente nos arts. 186, 187, 188 e 927 e seguintes do Código Civil e a responsabilidade contratual está disposta nos arts. 389 e seguintes do mesmo diploma legal.

35 Ricardo Luis Lorenzetti, Tratado de los contratos: parte general, Buenos Aires: Rubinzal - Culzoni, 2004, p. 589-590.

36 Idem, ibidem, p. 589-591. 
Carlos Roberto Gonçalves elenca como diferenças entre ambos os regimes: a) o ônus da prova, pois na responsabilidade contratual o credor só precisa comprovar que a prestação não foi cumprida, enquanto na extracontratual há, em regra, a necessidade de se provar a culpa do agente; b) a fonte de que promanam, na contratual, a convenção, e na aquiliana, o dever genérico de não lesar, de não causar dano a ninguém (neminem laedere); c) a capacidade do agente causador do dano, posto a convenção exigir agentes plenamente capazes ao tempo de sua celebração, sob pena de nulidade e de não produzir efeitos indenizatórios, ao passo que na obrigação derivada de um delito o ato praticado por um incapaz pode dar origem à reparação por aqueles que legalmente são os encarregados de sua guarda e, até mesmo, pelo próprio incapaz toda vez que as pessoas por ele responsáveis não tenham a obrigação legal de fazê-lo ou não disponham de meios suficientes (art. 928 do Código Civil); d) a gradação da culpa, eis que, em regra, a responsabilidade contratual e a extracontratual fundam-se na culpa, mas a obrigação de indenizar no âmbito da responsabilidade aquiliana deflui da lei que possui eficácia erga omnes, o que acarreta certo escalonamento quando decorrente de um contrato, de conformidade com os diferentes casos em que ela se configure, ao passo que na delitual a culpa irá mais longe, alcançando a ligeiríssima falta. ${ }^{37}$

Mariana Pazzianoto Deperon, por sua vez, vê como distinções entre a responsabilidade aquiliana e a contratual: a) ônus da prova, no campo da responsabilidade delitual a vítima é obrigada a provar a culpa do agente infrator, ao passo que no âmbito contratual a comprovação do dever violado consiste na infração do avençado ou daquilo que consta previsto em lei; b) origem, na responsabilidade contratual decorre da convenção ou de uma relação obrigacional, enquanto na extracontratual possui sua origem no dever de não causar prejuízo a outrem; c) capacidade do agente gerador do dano, em que no âmbito delitual o incapaz que der origem à reparação do dano será obrigado a indenizá-lo e no campo contratual a validade do negócio jurídico depende da capacidade do agente, sob pena de nulidade; d) gradação da culpa, pois na responsabilidade aquiliana basta a culpa leve para que surja

37 Carlos Roberto Gonçalves, Responsabilidade civil, 10. ed., São Paulo: Saraiva, 2007, p. 29-30. 
o dever de indenizar e na contratual não basta a mera culpa, mas exige-se uma apuração mais rigorosa da falta. ${ }^{38}$

Como se vê, em um sistema que adota a teoria clássica, a clivagem entre a responsabilidade contratual e a extracontratual apresenta considerável relevância. Contudo, consoante restará demonstrado, essa dicotomia não é suficiente para responder a algumas questões latentes em nosso ordenamento, como é o caso, por exemplo, da responsabilidade pré-contratual, ou, por outro lado, da responsabilidade por informações, conselhos e recomendações nas relações entre particulares, exatamente o objeto de nosso trabalho.

Por essa razão, pretende-se discutir a ideia acerca da concretização de uma responsabilidade civil, fundada na boa-fé objetiva e na confiança, e na possibilidade de seu acolhimento pela ordem jurídica brasileira.

Para tanto, deve-se partir da análise do panorama da responsabilidade contratual e extracontratual em nosso sistema atual, para, posteriormente, promovermos a digressão acerca da responsabilidade pela confiança e de sua adequação ao sistema jurídico brasileiro.

\subsection{Da responsabilidade extracontratual}

Com o advento do Código Civil de 2002 e a instituição de normas atinentes à disciplina dos direitos da personalidade (arts. 11 a 21), operou-se importante reforma no direito civil legislado, no âmbito da responsabilidade civil.

Neste contexto, com a redação do art. 927 de nosso Codex, operou-se relevante mudança em nosso sistema de direito privado, evidenciada pela adoção expressa da teoria do risco, consoante disposto no parágrafo único deste dispositivo

38 Mariana Pazianotto Deperon, Responsabilidade civil pela ruptura ilegítima das tratativas, Curitiba: Juruá, 2009, p. 223-224. 
legal, em que se prevê a possibilidade de existência de responsabilidade independentemente de culpa.

Ademais, em decorrência da adoção da responsabilidade que independa de culpa, dispõe o Código de 2002, em seu art. 932, acerca da responsabilidade pelo fato de outrem, em que se afasta da ideia de culpa presumida - e da consequente inversão do ônus da prova -, adotando-se a teoria do risco para os casos em questão, estabelecendo expressamente em seu art. 933 que responderão independentemente de culpa as pessoas responsáveis pelos atos dos terceiros mencionados nos incicos I a V do art. 932. Por outro lado, reconhece-se a solidariedade entre as pessoas responsabilizadas pelos danos causados por terceiros e estes próprios, nos termos do parágrafo único do art. 942.

Além disso, outra alteração de vulto promovida pelo legislador civil decorre da previsão expressa acerca do abuso de direito, nos termos do art. 187 do Código de 2002. Sobre o tema, Teresa Ancona Lopez ressalva a "revolucionária positivação da categoria jurídica abuso do direito como cláusula geral no novo Código Civil", 39 o que evidencia a importância de seu estudo para o desenvolvimento dessa tese.

Todavia, deve ser feita a ressalva no sentido de que as alterações mencionadas não decorrem de uma inovação radical do legislador ordinário, mas são fruto de um lento, gradual e pouco pacífico processo de evolução da responsabilidade civil, que se inicia pela ideia de culpa, passando pela culpa presumida, para depois, finalmente, abraçar a teoria do risco e da responsabilidade objetiva.

O percurso para a adoção da teoria do risco em nosso ordenamento e, em especial, para o estabelecimento da responsabilidade objetiva pelo fato de outrem foi pautado por intensa controvérsia, consoante será demonstrado.

39 Teresa Ancona Lopez, Exercício abusivo do direito e suas limitações, in: Rosa Maria de Andrade Nery e Rogério Donnini (Coord.), Responsabilidade civil: estudos em homenagem ao professor Rui Geraldo Camargo Viana, São Paulo: RT, 2009, p. 540. 


\subsubsection{Culpa e risco}

A evolução da teoria da culpa para a teoria do risco constituiu um processo moroso, controvertido e marcado por obstáculos.

De fato, alicerçado no sistema clássico consagrado pelo Código Civil francês de 1804, o Código de 1916 apresentava como princípios fundamentais a autonomia privada e o individualismo jurídico, característicos do pensamento liberal e individualista predominante no século XIX e primórdios do século $\mathrm{XX}$, em uma base axiológica fundada destacadamente na proteção do patrimônio e que sofreu efetiva alteração somente com o advento da Constituição Federal de 1988.

Sob essa ordem de valores a realização da pessoa decorria da aquisição de bens e da formação de um patrimônio. O direito de propriedade apresenta inegável importância e merece tutela diferenciada na codificação civil liberal, em torno do qual gravitavam os demais interesses privados, juridicamente tutelados. ${ }^{40}$

Trata-se da lógica liberal, que tem por escopo a não interferência do Estado nas relações de direito privado, concedendo-se aos indivíduos a liberdade de regular suas próprias relações, a partir de limites previamente estabelecidos por regras pouco sujeitas a alterações.

Essa concepção do individualismo possessivo, observa Joaquim José Gomes Canotilho, influencia de maneira decisiva a teoria liberal dos direitos fundamentais, "que os considerará sempre como direitos de defesa do cidadão perante o Estado, devendo este abster-se da invasão da autonomia privada". ${ }^{41}$

Por conseguinte, pode-se concluir que o Código de 1916 fundava-se no ideal liberal e individualista do século XIX, em que a autonomia privada se encontra

40 Paulo Luiz Netto Lôbo, Constitucionalização do direito civil, Revista de Informação Legislativa, Brasília, ano 36, n. 141, jan.-mar. 1999, p. 103.

41 José Joaquim Gomes Canotilho, Direito constitucional e teoria da Constituição, 3. ed., Coimbra: Almedina, 1999, p. 360. 
essencialmente fundamentada na liberdade de contratar e no direito de propriedade, entendendo-se o homem comum como "o cidadão dotado de patrimônio". ${ }^{4}$

Cabe ressaltar que, no tocante à responsabilidade civil, o Código Civil napoleônico adotou como fundamentos a culpa efetiva e provada, ${ }^{43}$ o que acabou por influenciar o legislador brasileiro de $1916 .^{44}$

Como se vê, o legislador francês disciplinou um princípio geral de responsabilidade civil que influenciou a legislação moderna, fundado na ideia de culpa $^{45}$ a chamada responsabilidade subjetiva. ${ }^{46}$

Como consequência, a culpa ocupa lugar de destaque no Código Civil de 1916 como fundamento da responsabilidade civil, consistindo no cerne do dever de indenizar. Como regra, se não houver culpa, inexiste o dever de indenizar, mesmo que exista dano.

42 Paulo Luiz Netto Lôbo, Constitucionalização do direito civil, cit., p. 101.

43 "Los redactores del Código Civil francés quisieron adoptar en todas las esferas, tanto en materia contractual como en materia delictual, la teoría tradicional: exigir la culpa" (Henri Mazeaud; Léon Mazeaud; André Tunc, Tratado teórico y práctico de la responsabilidad civil delictual y contractual, 5. ed., tradução de Luis Alcalá-Zamora Y Castillo, Buenos Aires: Ediciones Jurídicas EuropaAmérica, 1962, t. I, v. 2, p. 24). Em tradução livre: Os redatores do Código Civil francês quiseram adotar em todas as esferas, tanto em matéria contratual como em matéria delitual, a teoria tradicional: exigir a culpa.

44 "Foi no Código Civil francês de 1804 que se inseriu a noção de culpa na estrutura da responsabilidade civil, e foi sob inspiração dos arts. 1.382 a 1.385 que o nosso Código Civil assentou a noção fundamental do ato ilícito (art. 159)" (Caio Mário da Silva Pereira, Responsabilidade civil de acordo com a Constituição de 1988, 8. ed., Rio de Janeiro: Forense, 1998, p. 64).

45 Alvino Lima, em obra clássica, sintetiza, com precisão, a evolução da responsabilidade civil extracontratual até a edição do Código Civil francês de 1804: "Eis, em traços gerais, como se operou a evolução do instituto da responsabilidade civil extra-contratual: iniciada pela vingança, ascende à composição pecuniária, sem cuidar da culpabilidade, que aparece como a expressão máxima da influência da regra moral no direito, na época clássica do direito romano, para se corporificar em lei no direito Justiniano. E a despeito dos ensinamentos do direito estatutário e da escola jusnaturalista, descambando para a responsabilidade sem culpa, o Código Francês segue a tradição do seu antigo direito: proclama a responsabilidade sob o fundamento da culpa e talha, assim, no art. 1.382 do seu grande Código Civil, a pedra angular de toda a legislação moderna sobre a responsabilidade decorrente do ato lesivo" (Da culpa ao risco, São Paulo: RT, 1938, p. 22-23).

46 "A evolução do direito francês nos tempos modernos dispensa considerações mais longas. Basta recordar que se deu através da mais extraordinária obra de jurisprudência de todos os tempos. A tarefa dos tribunais franceses, atualizando os textos e criando um direito rejuvenescido, foi tão impressionante que não há quem a desconheça, na audácia fecunda que é um dos encantos do gênio francês" (José de Aguiar Dias, Da responsabilidade civil, cit., p. 34). 
Verifica-se, assim, que o foco central da responsabilidade civil subjetiva centra-se na figura do agente causador do dano e não na primazia do interesse da vítima, que é obrigada a provar a conduta culposa daquele para ver configurado o dever de indenizar.

Isso porque resulta da ideia central da culpa a necessidade de se promover a sua prova, o que constitui ônus a ser suportado, em princípio, pela vítima, de acordo com a clássica doutrina subjetiva.

Essa prova da conduta culposa do agente, em muitos casos de difícil consecução, permitia a formação de um cenário em que muitas vítimas de danos permaneciam sem ser devidamente indenizadas.

Giovanni Pacchioni já fazia a advertência acerca da imposição do ônus da prova à vítima, afirmando que, sem dúvida, no curso dos séculos, e especialmente no século passado, com o crescimento do industrialismo e em seguida às grandes descobertas técnicas, o princípio da imputabilidade demonstrou-se insuficiente para dar satisfação às necessidades da prática, tornando muito difícil às vítimas provarem o dolo ou a culpa do agente causador do dano, nem do nexo causal entre a culpa e o dano. ${ }^{47}$

Nesse mesmo sentido, ressalva Gustavo Rene Nicolau que em inúmeros casos "a exigência de tal prova equivalia, na prática, a não indenizar a vítima, contrariando a idéia que propugnava por uma ampliação dos casos de indenização, tendo em vista o foco da vítima". ${ }^{48}$

47 No original: "È però, d'altra parte, fuori di dubbio che nel corso dei secoli, e specialmente nel secolo passato, col dilagare dell'industrialismo e in seguito alle grandi scoperte tecniche, il principio dell'imputabilità si è dimonstrato insufficiente a dare equa soddisfazione ai bisogni della pratica, rendendo assai difficile ai danneggiati di dare la prova del dolo o della colpa del danneggiante, nonchè quella del raporto causale fra la colpa e il danno." (Giovanni Pacchioni, Elementi di diritto civile, 4. ed., Milão: Giuffrè, 1944, p. 304-305).

48 Gustavo Rene Nicolau, Efetiva aplicação da teoria do risco no Código Civil de 2002, in: Mario Luiz Delgado; Jones Figueiredo Alves (Coord.), Novo Código Civil: questões controvertidas responsabilidade civil, São Paulo: Método, 2006, v. 5, p. 225. 
Assim, a teoria clássica da culpa não se demonstrava suficientemente capaz de responder à dinâmica da sociedade industrial, que clamava pelo desenvolvimento da responsabilidade civil.

Por conseguinte, o pensamento doutrinário se desenvolveu em direção à evolução do instituto da responsabilidade civil, em busca da superação da ideia da culpa como elemento essencial para a configuração do dever de indenizar.

Alvino Lima registra com acuidade que à teoria clássica da culpa estava reservado "o mais intenso dos ataques doutrinários que talvez se registra na história da evolução de um instituto jurídico". ${ }^{9}$ Mais adiante, ressalva que as prementes necessidades da vida e o surgir de novos casos concretos, cuja solução não estava prevista em lei ou não era satisfatoriamente amparada, "levaram a Jurisprudência a ampliar o conceito de culpa e acolher, embora excepcionalmente, muitas das conclusões das novas tendências doutrinárias". 50

No direito francês é notória a atuação de Raymond Saleilles, Louis Josserand e Georges Ripert como artífices desse movimento pela evolução da responsabilidade civil e do acolhimento da teoria do risco. Porém, deve ser ressaltado o relevante papel representado pelas cortes francesas na evolução desse instituto. Sobre o tema, noticia Giselda Maria Fernandes Novaes Hironaka que a decisão fundamental da Corte de Cassation no "arrêt Teffaine", em 16.06.1896, foi recebida como "um avanço significativo e sintomático em prol da teoria do risco". 51

Trinta e cinco anos depois, nova decisão de relevo da Corte de Cassation francesa, no que ficou conhecido como "l'arret Jand'Heur", em 13.02.1930, consagra a evolução rumo a uma presunção de responsabilidade independentemente de culpa. ${ }^{52}$

\footnotetext{
49 Alvino Lima, Da culpa ao risco, cit., p. 21.

50 Idem, ibidem, p. 21.

51 Giselda Maria Fernandes Novaes Hironaka, Responsabilidade pressuposta - Evolução dos fundamentos e de paradigmas da responsabilidade civil na contemporaneidade, cit., p. 213.

52 Idem, ibidem, p. 213.
} 
Os reflexos desse verdadeiro movimento em busca da teoria do risco logo ecoaram no Brasil e foram acolhidos pela doutrina pátria, consoante registram, dentre outras, as obras de Alvino Lima, Wilson Melo da Silva e de José de Aguiar Dias. ${ }^{53}$

Contudo, antes da aplicação da teoria do risco, foi necessário um processo de diluição do rigor da teoria da culpa, que passa pela noção de culpa presumida, especialmente no tocante aos casos de responsabilidade por fato de terceiros.

Dessa forma, a noção de culpa presumida, ${ }^{54}$ com a consequente inversão do ônus da prova ao agente causador do dano, representava importante alento para os partidários da doutrina subjetiva, em especial porque permitia a superação do princípio de que cada um responde por sua própria culpa (unuscuique sua culpa nocet), tornando possível a ideia de responsabilidade civil por fato alheio.

Caio Mário da Silva Pereira observa que a elaboração da noção de culpa presumida, neste caso, decorreu da intenção de não se levar tão longe a imputação de responsabilidade pelo fato de terceiro e adotar a teoria do risco. Assim, "abandonando os conceitos de culpa in vigilando ou in eligendo, vai-se então buscar suporte na presunção de culpa". 55

Não se pode negar que o estabelecimento da presunção de culpa com a inversão do ônus da prova propicia uma melhora considerável na situação da vítima e representa uma forma de aumentar o número de danos efetivamente indenizados. ${ }^{56}$

\footnotetext{
53 Alvino Lima, Da culpa ao risco, cit., 1938. Wilson Melo da Silva, Responsabilidade sem culpa, 2. ed., Saraiva: São Paulo, 1974. José de Aguiar Dias, Da responsabilidade civil, cit., 1973.

54 A evolução do entendimento jurisprudencial brasileiro, com base na noção de culpa presumida, levou à edição da Súmula 341 do Supremo Tribunal Federal, que assim dispõe: "É presumida a culpa do patrão ou comitente pelo ato culposo do empregado ou preposto".

55 Caio Mário da Silva Pereira, Responsabilidade civil de acordo com a Constituição de 1988, cit., p. 86.

56 Como bem observa Wilson Melo da Silva, "ao invés de ter de demonstrar o lesado, de conformidade com os cânones consagrados da teoria clássica, além da relação de causa e efeito entre o ato e o dano, a imputabilidade, subjetiva, do evento atribuível ao autor dele, bastava que ficasse apenas na simples relação de causa e efeito entre o ato do agente e a lesão de que se queixasse. A culpa psicológica, subjetiva, seria, então, presumida" (Wilson Melo da Silva, Responsabilidade sem culpa, cit., p. 84).
} 
Impor ao agente causador do dano a prova da inexistência da culpa ou da ocorrência de alguns dos excludentes de responsabilidade significava amparar a vítima de uma forma mais concreta e eficiente do que exigir a prova da culpa psicológica, subjetiva, daquele que causou a lesão.

Porém, esse expediente que possui natureza mais processual que substantiva, como bem relata Wilson Melo da Silva, não chegava, em verdade, a excluir a culpa, uma vez que ao agente era ressalvado o direito de demonstrar o inverso, demonstração essa que, em circunstâncias várias, não lhe era difícil. ${ }^{57}$

Dessa forma, impunha-se a adoção de uma teoria que pudesse ser capaz de superar a necessidade da culpa para a reparação do dano, exigindo-se para o dever de indenizar apenas a prova da relação de causalidade entre a conduta e o dano: a teoria do risco.

Passa-se, então, à concepção de que a pessoa que, no seu interesse, cria um risco de causar dano a outrem terá o dever de repará-lo, se este dano sobrevier. ${ }^{58}$ Assim, nas palavras de Carlos Roberto Gonçalves, "a responsabilidade deixa de resultar da culpabilidade, para derivar exclusivamente da causalidade material. Responsável é aquele que causou o dano". 59

Desse modo, afasta-se da necessária prova da culpa para se determinar que o dano deve ser reparado pelo seu causador desde que exista uma relação de causalidade entre a sua conduta e o prejuízo causado à vítima.

Pela adoção do sistema amparado na responsabilidade objetiva, parte-se da ideia de risco. Em princípio, defendeu-se a reparação integral do dano, até mesmo daquele involuntário, em uma doutrina extremada que possuía como pressuposto a eliminação do elemento pessoal. Passou-se então à teoria do ato anormal, baseada no surgimento da responsabilidade toda vez que, no uso da propriedade, a atividade do agente possa ser considerada alheia aos padrões de normalidade e conformidade. No

\footnotetext{
57 Wilson Melo da Silva, Responsabilidade sem culpa, cit., p. 84.

58 Carlos Roberto Gonçalves, Responsabilidade civil, cit., p. 536.

59 Idem, ibidem, p. 536.
} 
entanto, a teoria objetiva fundada no risco criado pelas inúmeras atividades humanas foi a que se demonstrou apta a permitir a evolução do instituto da responsabilidade civil, fixando-lhe as bases. ${ }^{60}$

Destarte, a pedra angular da responsabilidade objetiva nos dias de hoje é a ideia de risco, que apresenta uma concepção vária, representada em distintas teorias.

Pela teoria do risco-proveito ${ }^{61}$ a responsabilidade encontra fundamento no proveito retirado pelo responsável no exercício de uma atividade potencialmente danosa. Onde existirem as vantagens, também existirá o risco.

Na lição de Karl Larenz, ${ }^{62}$ essa teoria funda-se no pensamento de que aquele que obtém a vantagem há de tomar também sobre si os prejuízos que dela decorrem para outros. É possível dizer que a pessoa que empreende uma atividade permitida que possa criar ou manter uma fonte de perigos para outros carrega sobre si uma responsabilidade especial e, por consequência, há de responder pelo perigo. ${ }^{63}$

Sendo assim, o proveito decorrente do exercício de uma atividade de potencial danoso efetivo traz como consequência a responsabilidade pelos seus riscos, independentemente da prova da culpa do agente.

Importa salientar, contudo, que, mesmo em não havendo lucro, persiste a responsabilidade, pois, como bem adverte Alvino Lima, “o proveito não se determina concretamente, mas é tido como finalidade da atividade criadora de risco". ${ }^{64}$

\footnotetext{
60 Alvino Lima, Da culpa ao risco, cit., p. 89-93.
}

44 "Responsabilidade civil. Cancelamento de vôo. Empresa de transporte aéreo. Natureza objetiva. Teoria do risco. Risco-proveito. Código de Defesa do Consumidor. Princípios da vulnerabilidade e da boa-fé. Dano moral. Indenização. Pedido procedente. Fixação do valor" (TJMG, APCV 1.0024.07.444321-9/0011, Belo Horizonte, 14. ${ }^{a}$ Câm. Cív., rel. Desig. Des. Hilda Teixeira da Costa, j. 21.08.2008, DJEMG 09.09.2008).

62 Karl Larenz, Derecho de obligaciones, versão espanhola de Jaime Santos Briz, Madrid: Revista de Derecho Privado, 1959, t. II, p. 664.

63 "Lo cual se funda en el pensamiento de que el que obtiene la ventaja ha de tomar también sobre si los perjuicios que a ella van unidos para otros. Se puede decir que la persona que emprende una actividad permitida que puede crear o mantener una fuente de peligros para otros carga sobre sí por ello una responsabilidad especial y, como consecuencia, ha de responder del peligro."

64 Alvino Lima, Da culpa ao risco, cit., p. 147. 
Pela teoria do risco-criado, ${ }^{65}$ por sua vez, possuem o dever de indenizar aqueles que por sua atividade criam perigo a outrem.

Sobre a teoria do risco criado, ensina Caio Mário da Silva Pereira que se trata de ampliação do conceito de risco proveito, posto aumentar os encargos do agente e ser mais equitativa para a vítima, que "não tem de provar que o dano resultou de uma vantagem ou de um benefício obtido pelo causador do dano. Deve este assumir as consequências danosas de sua atividade". 66

A teoria do risco-profissional, ${ }^{67}$ por seu turno, não cogita da ideia de culpa para que exista a responsabilidade do empregador pela reparação do dano causado ao empregado no exercício da atividade laboral ou em razão dela.

Desse modo, pela teoria do risco profissional, o dever de indenizar deriva da atividade ou profissão da vítima, imputando-se ao empregador a reparação dos danos causados ao empregado em razão ou por ocasião do exercício do seu trabalho.

Sobre o tema, é importante salientar o disposto no art. $7 .^{\circ}$, inc. XXVIII, da Constituição Federal, ao estabelecer como direito do trabalhador "o seguro contra acidentes de trabalho, a cargo do empregador, sem excluir a indenização a que este está obrigado, quando incorrer em dolo ou culpa”, evidenciando-se a necessária prova da

65 "Acidente de trabalho. Dano estético e moral. Risco criado pela empregadora. Culpa caracterizada. A reclamada, na condição de empregadora e, portanto, responsável pelos riscos da atividade empresarial, tem a incumbência de zelar pela segurança de seus empregados. E, ao expor o reclamante a trafegar nos autos de um trio elétrico, por ruas notoriamente arborizadas e com grande quantidade de fiação elétrica, suspensa e aparente, inclusive de iluminação pública, colocou-o em situação de risco, agravada pela inexistência de qualquer medida de proteção. Culpa reconhecida que enseja a obrigação de indenizar" (TRT 8. ${ }^{\text {a }}$ Reg., RO 01770-2007-014-08-00-3, 2. ${ }^{\text {a }}$ Turma, rel. Des. Federal Odete de Almeida Alves, DJEPA 13.10.2008, p. 6).

66 Caio Mário da Silva Pereira, Responsabilidade civil de acordo com a Constituição de 1988, cit., p. 285.

67 "Processo civil. Argüição de nulidade da sentença pela inversão do ônus da prova. Possibilidade, mormente por se tratar de relação de consumo. Regra de julgamento. Nulidade não reconhecida. BANCOS. Responsabilidade objetiva. Relação de consumo. Caráter público dos serviços prestados. Poupança. Saques indevidos. Ônus decorrente da atividade. Teoria do risco profissional. Prestação de serviços inseguros e defeituosos. Privação dos direitos inerentes à propriedade. Dano moral configurado. Sentença mantida. Apelação não provida" (TJSP, APL 7238670-4, Ac. 3254441-São Paulo, 13. ${ }^{a}$ Câm. de Direito Privado D, rel. Des. Luís Eduardo Scarabelli, j. 12.09.2008, DJESP 13.10.2008). 
culpa lato sensu na hipótese de responsabilidade do empregador perante o empregado por danos decorrentes de acidentes do trabalho.

Já pela teoria do risco-administrativo, ${ }^{68}$ cabe ao Estado responder objetivamente pelos danos causados pelos agentes da Administração, sem que haja qualquer culpa ou que ocorra a falta do serviço. ${ }^{69}$

A atividade exercida pelo Estado atinge a todos sem exceção, o que faz com que a Administração Pública responda pelos danos causados por seus agentes independentemente de culpa. Por conseguinte, a coletividade suporta os prejuízos causados ao particular, posto a atividade administrativa ser exercida em favor de todos.

$\mathrm{Na}$ teoria do risco-excepcional, consoante bem observa Cavalieri Filho, "a reparação é devida sempre que o dano é consequência de um risco excepcional que escapa à atividade comum da vítima, ainda que estranho ao trabalho que normalmente exerça" ${ }^{70}$ Assim, o exercício de atividades incomuns, geradora potencial de riscos considerados excepcionais, tais como as usinas nucleares, impõe a reparação dos danos por elas causados independentemente de culpa. ${ }^{71}$

68 "Administrativo. Processual civil. Responsabilidade civil do estado. Responsabilidade objetiva. Teoria do risco administrativo. Conduta imputada a agente público. Relação entre a função pública exercida pelo agente e o fato gerador do dano. Fato de terceiro. Excludente de responsabilidade. Inexistência. Exposição de terceiros a riscos criados por ação estatal. Veículo oficial. Uso por agente público para fins particulares. Acidente. Morte dos pais da recorrida. Danos materiais. Matéria de prova. Danos morais. Quantificação. Controle pelo STJ. Critério da exorbitância ou irrisoriedade do valor. Termo inicial da correção monetária dos danos extrapatrimoniais. Data do arbitramento. Omissão, obscuridade e contradição inexistentes. Continência e sucumbência recíproca. Não ocorrência. Embargos prequestionadores. Multa afastada" (STJ, REsp 866.450, Proc. 2006/01391973-RS, 2. ${ }^{a}$ Turma, rel. Min. Herman Benjamin, j. 24.04.2007, DJE 07.03.2008) (Publicado no DVD Magister n. 21 - Repositório Autorizado do STJ n. 60/2006 e do TST n. 31/2007).

69 Ensina Sérgio Cavalieri Filho que "a Administração Pública gera risco para os administrados, entendendo-se como tal a possibilidade do dano que os membros da comunidade podem sofrer em decorrência da normal ou anormal atividade do Estado. Tendo em vista que essa atividade é exercida em favor de todos, seus ônus devem ser também suportados por todos, e não apenas por alguns. Consequentemente, deve o estado, que a todos representa, suportar os ônus da sua atividade, independentemente de culpa por seus agentes" (Programa de responsabilidade civil, 7. ed., São Paulo: Atlas, 2007, p. 223).

$70 \quad$ Sérgio Cavalieri Filho, Programa de responsabilidade civil, cit., p. 129.

71 "Vigilante. Atividade de risco. Responsabilidade objetiva. Morte em serviço. Quando a atividade desenvolvida pelo autor do dano implicar, por sua natureza, risco para os direitos de outrem (parágrafo único do art. 927 do Código Civil), torna-se desnecessária a comprovação da culpa, visto que, nesse caso, aplica-se a teoria do risco, sendo o empregador responsabilizado de forma objetiva. 
A teoria do risco-integral representa o pensamento daquela posição extremada em que o dever de indenizar existiria até mesmo na ausência do nexo de causalidade.

Cabe ressaltar que a adoção da teoria do risco pelo Código Civil de 2002 representa a evolução da necessária marcha do instituto da responsabilidade civil em direção da tutela do interesse da vítima, fundada nos ideais de solidariedade social, de eticidade, de equidade e, principalmente, de preservação da dignidade da pessoa humana, que constituem os pilares de nosso ordenamento jurídico.

Não se pretende, por óbvio, afirmar o sepultamento da teoria da culpa e o início do império da responsabilidade objetiva. Pelo contrário, não se tem por escopo sustentar a primazia do risco sobre a culpa, mas pretende-se ressalvar a importância de se buscar um sistema de pesos e contrapesos entre as teorias objetiva e subjetiva, com vistas a permitir que o interesse da vítima seja defendido com prioridade. ${ }^{72}$

Assim, o desafio consistirá no constante aperfeiçoar do sistema de responsabilidade civil, no sentido da aproximação com o fato social, que é a fonte do direito, a fim de tornar possível a inclusão, minorando-se a exclusão do indivíduo que é a vítima do ato danoso, tornando propício o terreno da pacificação social.

$\mathrm{Na}$ hipótese, verifica-se com nitidez a presença do risco criado, hábil a justificar a adoção da responsabilidade objetiva, valendo dizer que a atividade de guarda armada exercida pelo vigilante o expõe a um perigo muito maior do que aquele que a maior parte da coletividade está sujeita, abrindo espaço para uma maior probabilidade de acidentes de trabalho, implicando em risco muito mais agravado, por sua própria natureza, para o indivíduo que a desempenha e para terceiros, a exemplo do que se dá em caso de transporte de explosivos, transmissão de energia elétrica e exploração de energia nuclear, atividades que expõem a expressivo perigo quem se presta a executá-las, assim como a própria comunidade" (TRT 23. ${ }^{\mathrm{a}}$ Reg., RO 01773.2005.007.23.01-8, rel. Des. Roberto Benatar, j. 05.06.2007, DJEMT 18.06.2007) (Publicado no DVD Magister n. 18 - Repositório Autorizado do STJ n. 60/2006 e do TST n. 31/2007).

72 Nesse sentido, bem observa Teresa Ancona Lopez, "muito se tem debatido sobre a 'volta' da culpa à teoria da responsabilidade civil. Na verdade, a culpa continua sendo um de seus fundamentos. No século XX, mesmo quando a teoria do risco adquiriu força, a culpa continuou cumprindo seu papel em muitos institutos (como, por exemplo, responsabilidade dos profissionais liberais, em especial dos médicos e advogados), mas sempre foi, principalmente, o fundamento da responsabilidade contratual e pré-contratual, ocupando posição importante entre as causas exonerativas da responsabilidade civil objetiva, com as hipóteses de culpa exclusiva da vítima ou de terceiros" (Princípio da precaução e evolução da responsabilidade civil, cit., p. 131). 
Afinal, como magnificamente afirma Rabut, é incontestável que os danos causados, seja às pessoas, seja aos bens, constituem por si uma perda lastimável, não só para o indivíduo que é a vítima, mas para toda a sociedade. ${ }^{73}$

\subsection{Da responsabilidade contratual}

O contrato constitui um elemento fundamental das relações privadas, essencial para a circulação de riquezas e para o desenvolvimento dos estados nacionais em um regime capitalista como o que vivemos.

Esse instituto jurídico cada vez mais complexo possui lugar de destaque na civilização hodierna, pois permeia-se por todas as relações intersubjetivas. O homem de hoje contrata em incontáveis momentos de seu dia a dia, seja no momento de entrar em um ônibus para se dirigir ao seu local de trabalho, seja quando decide pela construção de um arranha-céu. ${ }^{74}$

Ao longo do tempo o contrato vem ganhando dimensão de relevo, inclusive como instrumento das políticas públicas de regulação do mercado, que, como bem salienta Enzo Roppo, visam a se opor "às práticas anticoncorrenciais, às assimetrias informativas e a outras "falhas do mercado", ${ }^{75}$

Essa dinâmica e multifacetada transformação produz reflexos em todo o sistema jurídico, tornando-se necessário o afastamento da concepção clássica de contrato fundada sob o império do pacta sunt servanda, como se, uma vez celebrado, o

73 "Il est incontestable que les dommages soit aux personnes soi aux biens constituent en eux-mêmes une perte regrettable non seulement pour l'individu qui en est la victime, mais pour la societè tout entière" (A. Rabut, La notion de faut en droit privè, Paris, 1949, n. 127, p. 156 apud Wilson Melo da Silva, Responsabilidade sem culpa, cit., p. VII).

74 "O liberalismo econômico, a idéia basilar de que todos são iguais perante a lei e devem ser igualmente tratados, e a concepção de que o mercado de capitais e o mercado de trabalho devem funcionar livremente em condições, todavia, que favoreçam a dominação de uma classe sobre a economia considerada em seu conjunto permitiram fazer do contrato o instrumento jurídico por excelência da vida econômica" (Orlando Gomes, Contratos, 26. ed., rev., atual. e aum. por Antonio Junqueira de Azevedo e Francisco Paulo de Crescenzo Marino, Rio de Janeiro: Forense, 2007, p. 7).

75 Enzo Roppo, O contrato, tradução de Ana Coimbra e M. Januário C. Gomes, Coimbra: Almedina, 2009 , p. 4. 
pacto se transformasse em verdadeira caixa de pandora, cerrado e inquebrantável, impossível de ser revisto em seu conteúdo, sob pena de se libertarem todos os males.

Assim, a despeito de se falar em uma crise no contrato em virtude da propalada hipertrofia da boa-fé, ${ }^{76}$ o fato é que as relações contratuais hodiernas atingiram tal grau de complexidade que ultrapassaram as fronteiras da teoria contratual clássica e passaram a demandar a construção de uma nova teoria contratual, partindo-se de novos paradigmas e fundada em uma concepção social desse instituto tão essencial para o desenvolvimento da vida em sociedade.

Em nossa opinião, não existe uma crise do contrato, mas uma necessária evolução da teoria contratual, a fim de acompanhar o impressionante desenvolvimento social impulsionado pela globalização e pela nova lex mercatoria que impera nos dias de hoje e atingiu de maneira irreversível os diversos setores da sociedade, especialmente no que se refere às relações de troca e à circulação de riquezas, tornando imperiosa uma releitura da antiga teoria contratual, em busca de uma nova concepção de contrato, mais consentânea com a realidade atual.

Impõe-se uma nova perspectiva para o contrato, voltada para as suas múltiplas possibilidades e para os seus inúmeros modelos, a fim de que o sistema possa se amoldar à nova dinâmica das relações sociais, cada vez mais volátil e fragmentada. ${ }^{77}$

76 "Foram os autores franceses, Christophe Jamin e Denis Mazeaud, que, em 2003, utilizaram essa expressão "nova crise do contrato" para denominar o atual momento de insegurança por que passa a teoria contratual, momento de grandes dúvidas dogmáticas sobre os temas básicos e o próprio futuro dos contratos. Esses autores franceses afirmavam em vários momentos que a nova crise dos contratos teria seu fundamento, na França, justamente na multiplicação criada pelo direito do consumidor de cláusulas gerais no direito privado e no que denominavam de hipertrofia da cláusula geral de boa-fé em face das decisões contraditórias dos magistrados naquele país no que se refere aos contratos" (Claudia Lima Marques (Org.), A chamada nova crise do contrato e o modelo de direito privado brasileiro: crise de confiança ou de crescimento do contrato?, A nova crise do contrato: estudos sobre a nova teoria contratual, São Paulo: RT, 2007, p. 19).

77 "De um ponto de vista sistemático registra-se a crescente fragmentação do fato jurídico, ou, pelo menos, a perda de centralidade da figura e da disciplina geral do contrato, concebida de modo unitário. Avança de modo prepotente, uma lógica anti-unitária, pluralista e multipolar, que prefere pensar no 'contrato' como numa galáxia de diferentes tipos ou classes de contratos, cada um com a sua disciplina diferenciada da dos outros” (Enzo Roppo, O contrato, cit., p. 4). 
Nesse vasto terreno pelo qual se desenvolvem as relações contratuais, poucas não são as situações potencialmente lesivas às partes contratantes ou a terceiros, o que demonstra a relevância de se proceder ao estudo da responsabilidade contratual, especialmente no que tange ao tema aqui proposto, pois a troca de informações, conselhos e recomendações é frequente no momento da execução dos contratos e pode ser fonte de dano.

No Código Civil de 2002 operou-se a consagração de princípios contratuais que alteraram radicalmente o nosso sistema jurídico, em especial no que tange à responsabilidade contratual.

Neste sentido merece destaque a previsão do art. $421^{78}$ do Código Civil, dispondo que o exercício da liberdade de contratar encontra sua razão e limites na função social do contrato; bem como o disposto em seu art. $422,{ }^{79}$ em que se consagra o princípio da boa-fé objetiva e de seus deveres anexos como obrigação dos contratantes, seja na fase de conclusão do contrato, seja em sua execução.

Além disso, operou-se a necessária revisão dos princípios contratuais clássicos, tais como o princípio da autonomia da vontade e o da obrigatoriedade das convenções, a fim de adaptá-los à nova ordem jurídica e à base de valores insculpida na Constituição Federal de 1988.

Por conseguinte, faz-se necessário proceder-se à análise de três princípios contratuais fundamentais para nosso ordenamento, iniciando-se por uma releitura do princípio da autonomia privada, para se chegar aos princípios da função social dos

78 "Art. 421. A liberdade de contratar será exercida em razão e nos limites da função social do contrato."

"Art. 422. Os contratantes são obrigados a guardar, assim na conclusão do contrato, como em sua execução, os princípios de probidade e boa-fé."

79 "Art. 421. A liberdade de contratar será exercida em razão e nos limites da função social do contrato."

"Art. 422. Os contratantes são obrigados a guardar, assim na conclusão do contrato, como em sua execução, os princípios de probidade e boa-fé." 
contratos e da boa-fé objetiva, a fim de que se possa delimitar os novos paradigmas da responsabilidade contratual essenciais ao desenvolvimento de nosso trabalho.

\subsubsection{A autonomia privada ${ }^{80}$}

A liberdade de contratar concedida pela ordem jurídica emana da faculdade dos sujeitos para criarem direitos e estabelecerem vínculos jurídicos para com outras pessoas. A liberdade para decidir pela celebração de um contrato com outrem, assim como para estabelecer o conteúdo desta avença, disciplinando-se as normas que regulamentarão essa relação, constitui característica essencial do trato social.

Sobre o tema, Menezes Cordeiro ressalva a dupla utilização da autonomia privada, ao assinalar que, em sentido amplo, equivale ao espaço de liberdade concedido a cada um na ordem jurídica, abrangendo tudo o que as pessoas podem fazer num prisma material ou jurídico. Já em um sentido estrito, corresponde ao espaço de liberdade jurígena, ou seja, àquela área reservada através da qual as pessoas podem desenvolver as atividades jurídicas que bem entenderem. ${ }^{81}$

Trata-se, por conseguinte, de princípio essencial para o desenvolvimento das relações humanas, posto consistir em alicerce básico da convivência social. Caso contrário, as pessoas estariam limitadas a praticar atos prévia e expressamente estabelecidos no ordenamento jurídico, sem qualquer espaço para a autodeterminação, o que significaria o engessamento das relações humanas e a consequente estagnação da economia, da circulação de riquezas e de capital. ${ }^{82}$

80 Neste trabalho dá-se preferência à denominação autonomia privada em detrimento de autonomia da vontade, a fim de não se reforçar a ideia do dogma da vontade, mantendo-se cautelosa distância das teorias voluntaristas, o que será fundamental para o desenvolvimento desta tese. "Sinônimo de autonomia da vontade para grande parte da doutrina contemporânea, com ela porém não se confunde, existindo entre ambas uma sensível diferença. A expressão 'autonomia da vontade' tem uma conotação subjetiva, psicológica, enquanto a autonomia privada marca o poder da vontade no direito de um modo objetivo concreto e real" (Francisco Amaral, Direito civil: introdução, 6. ed., Rio de Janeiro: Renovar, 2006, p. 346).

81 António Manuel da Rocha e Menezes Cordeiro, Tratado de direito civil português. Parte geral, Coimbra: Almedina, 2007, t. I, p. 391.

82 “O indivíduo só pode existir socialmente como personalidade quando lhe seja reconhecida, pelos demais, não só sua esfera de personalidade e da propriedade, senão quando, ademais, possa em 
Na precisa definição de José de Oliveira Ascensão, a autonomia consiste no poder de estabelecer as suas próprias regras, criando um ordenamento próprio, significando que a "ordem jurídica global admite que os particulares participem da construção da sua própria ordem jurídica, nos quadros embora da ordem jurídica global". ${ }^{83}$

No âmbito dos contratos, essa autodeterminação consubstancia-se na liberdade de contratar que se exerce e concretiza na faculdade de contratar, na liberdade de escolher com quem se pretende celebrar esse contrato e na possibilidade de determinar o conteúdo desse pacto, o que, consoante ensina Enzo Roppo, significa definir "a composição ou o arranjo recíproco que receberão os interesses das partes, coenvolvidos na operação econômica e a que o contrato é chamado a dar veste e vinculatividade jurídica". 84

Desse modo, para a convivência social, assim como para o desenvolvimento das relações humanas, é necessário garantir que as pessoas tenham liberdade para determinar as suas próprias regras, assim como aquelas que regulamentarão as suas convenções com outros sujeitos, sempre de acordo com as normas que compõem a ordem jurídica a que estão subordinados.

Por conseguinte, é possível verificar que a tutela da autonomia privada constitui um dos valores fundamentais do ordenamento jurídico, ${ }^{85}$ consoante assevera

princípio regulamentar por si mesmo suas questões pessoais e, contanto que com ele esteja afetada outra pessoa, possa regulamentar suas relações com ela, com caráter juridicamente obrigatório, mediante um acordo livremente estabelecido." No original: "El individuo sólo puede existir socialmente como personalidad cuando le sea reconocida por los demás no solo su esfera de la personalidad y de la propiedad, sino cuando, además, pueda en principio reglamentar por sí mismo sus cuestiones personales y, en tanto con ello quede afectada por otra persona, pueda reglamentar sus relaciones con ella con carácter jurídicamente obligatorio mediante un concierto libremente establecido" (Karl Larenz, Derecho de obligaciones, versão española de Jaime Santos Briz, Madrid: Revista de Derecho Privado, 1959, t. I, p. 65).

83 José de Oliveira Ascensão, Direito civil: teoria geral. Ações e fatos jurídicos, 2. ed. Coimbra: Coimbra Ed., 2003, v. 1, p. 79-80.

84 Enzo Roppo, $O$ contrato, cit., p. 26.

85 "Do ponto de vista institucional e estrutural dominante na teoria geral do direito, a autonomia privada constitui-se em um dos princípios fundamentais do sistema de direito privado num reconhecimento da existência de um âmbito particular de atuação com eficácia normativa. Trata-se de projeção, no direito, do personalismo ético, concepção axiológica da pessoa como centro e destinatário da ordem jurídica privada, sem o que a pessoa humana, embora formalmente revestida 
Guido Alpa, ${ }^{86}$ não obstante se encontre limitada pela ordem pública, pelos bons costumes e pela boa-fé.

De fato, a liberdade ilimitada para contratar e para estabelecer as regras que disciplinarão as suas relações com outras pessoas acaba resultando em situações iníquas, frequentemente representadas pela imposição de normas por parte daquele que detém o poder econômico em detrimento do outro que necessita de recursos para prover a sua subsistência.

Para os adeptos de uma ordem liberal absoluta, não haveria espaço para o Estado intervir nas relações entre particulares, eis que aí se apresenta o domínio da autonomia privada, significando que a liberdade para contratar seria irrestrita e ilimitada, subordinando-se, apenas, aos ditames de um ente superior denominado mercado.

No entanto, a experiência humana é prenhe de exemplos capazes de demonstrar que a lógica ilimitada do mercado deságua na apropriação de riquezas por parte de uns poucos privilegiados e na ampliação da miséria por parte de outros tantos, impondo-se a intervenção do poder público a fim de atingir os ideais de solidariedade e de dignidade humana, tão caros aos sistemas que se fundam em uma ordem jurídica justa. ${ }^{87}$

O desenvolvimento do capitalismo ao longo da história está caracterizado por destacada desigualdade econômica e social, em que os detentores do poder econômico demonstram uma inegável habilidade para exercê-lo, impondo sua vontade aos demais, tudo sob o pálio da igualdade formal estabelecida pelo sistema. Qualquer

de titularidade jurídica, nada mais seria do que mero instrumento a serviço da sociedade" (Francisco Amaral, Direito civil: introdução, 6. ed., cit., p. 346).

86 "Il princípio di autonomia contrattuale è considerato uno dei valori fondamentali degli ordenamenti giuridici” (Guido Alpa, Corso di diritto contrattuale, Padova: Cedam, 2006, p. 276).

87 "Há uma ordem global em que o ordenamento superior e o ordenamento autônomo se inserem. Essa ordem rege a criação autônoma; e não poderia deixar de a reger, porque o homem é por natureza propenso a subestimar os seus interesses e sacrificar os dos outros. Uma criação autônoma sem limites seria a selvageria dos mais fortes e poderosos. A isso fecha os olhos o super-liberalismo selvagem dos nossos dias, propondo uma fé sem revelação no happy end, ou reduzida ao culto do mercado" (José de Oliveira Ascensão, Direito civil: teoria geral. Ações e fatos jurídicos, cit., p. 81). 
tentativa de delimitar o âmbito das relações contratuais, com vistas à preservação do lado economicamente mais frágil e à consecução de uma avença mais equânime, era considerada uma ingerência indevida e abominável afronta à liberdade de contratar.

Neste diapasão, a igualdade de todos perante a lei significaria a presunção de que os contratos eram celebrados em uma base sólida de equilíbrio entre as partes, que, livres para decidir sobre os termos do pacto, para assumir ou não as obrigações ali estabelecidas e para escolher com quem contratar, teriam feito a opção que melhor lhes conviesse, razão pela qual não haveria lugar para a intervenção do Estado nas relações privadas.

Contudo, as distorções decorrentes do exercício abusivo dessa liberdade e os danosos reflexos sociais daí resultantes tornaram imperiosa a intervenção estatal no sentido de regulamentar as relações privadas, através da edição de leis que visavam à coibição dos abusos e à diminuição das desigualdades. ${ }^{88}$

Na verdade, a igualdade formal, preconizada pelos ferrenhos defensores do liberalismo, não se verifica na realidade da vida social, em que o desequilíbrio entre as partes contratantes é latente, caracterizado pela concentração do poder econômico e pela imposição de condições contratuais, bem como pela difusão dos contratos de massa, representados por contratos de adesão, que deixam às partes menos favorecidas apenas a opção de "aderir ou não" ao contrato, sem a possibilidade de exercício da autodeterminação. Essa mesma distorção se verifica de maneira bastante evidente nos contratos de trabalho, pois o limitado número de vagas de emprego leva o empregador à posição bastante confortável de impor suas regras àqueles que pretendam com ele laborar. O mesmo acontece em inúmeras outras situações, tais como nos contratos de

88 "Mas de tal modo se abusou dessa liberdade, sobretudo em algumas espécies contratuais, que a reação cobrou forças, inspirando medidas legislativas tendentes a limitá-las energicamente. $\mathrm{O}$ pensamento jurídico modificou-se radicalmente, convencendo-se os juristas, como se disse lapidarmente, que entre o forte e o fraco é a liberdade que escraviza e a lei que liberta" (Orlando Gomes, Contratos, cit., p. 8). 
locação de imóveis residenciais ou de mútuo feneratício, demandando a necessária intervenção do Estado para intentar equilibrar forças tão díspares. ${ }^{89}$

Assim, a ordem pública constitui bastião da limitação da autonomia da vontade, a fim evitar a concretização de situações eivadas de iniquidade e de abuso do poder econômico e, por que não dizer, jurídico, eis que o acesso ao conhecimento e à melhor técnica jurídica também pende para o lado mais forte economicamente, o que se traduz em mais uma forma de manipulação das forças contratuais, como é o caso de inúmeros contratos de massa, carregados de cláusulas leoninas e abusivas, muitas das quais sequer conhecidas pelos aderentes, que ignoram por completo a sua verdadeira amplitude e alcance.

Dessa forma, incumbe ao Estado interferir na esfera de liberdade e de autonomia da pessoa, em defesa da ordem pública ${ }^{90}$ e do bem-estar social, função esta cada vez mais premente e necessária em um sistema como o brasileiro, fundado na dignidade humana e no solidarismo social, mas que vive sob a égide do capitalismo e de seu onipotente vetor, denominado mercado.

Esse conflito entre a autonomia privada e a ordem pública, os bons costumes e, especialmente, a boa-fé objetiva constitui questão fulcral a ser discutida em nossa tese, pois a liberdade para prestar informações conselhos ou recomendações será sempre levantada por aqueles que empunham a bandeira do liberalismo, a fim de evitar

89 "Do ponto de vista moral tem-se demonstrado que os princípios da liberdade e da igualdade não se realizam harmonicamente. A igualdade perante a lei é meramente formal; no campo material, vale dizer, no campo das relações sociais e das oportunidades de progresso econômico, as desigualdades são profundas. O exercício da liberdade contratual, por exemplo, pode levar os segmentos sociais mais carentes de recursos e, por isso mesmo, desprovidos de poder econômico de confronto ou de negociação, a acentuados desníveis econômicos, do que é exemplo a miséria das classes menos favorecidas, o que leva o Estado a intervir para equilibrar o poder das partes contratantes, estabelecendo normas imperativas em matéria de ordem pública ou bons costumes" (Francisco Amaral, Direito civil: Introdução, 6. ed., cit., p. 359).

90 Tercio Sampaio Ferraz ensina que a interferência do Estado na esfera de ação do indivíduo pode ser entendida pela noção de status negativus: "Se o próprio Estado está submetido à ordem jurídica constitucional, então a subordinação do indivíduo ao Estado (soberania) deve estar limitada ao que a ordem prescreve. Ora aquilo que resta ao indivíduo, subtraídas todas as limitações juridicamente (leia-se constitucionalmente) estabelecidas para a ação individual, isso constitui a esfera de ação livre do indivíduo" (Liberdade de opinião, liberdade de informação: mídia e privacidade, Cadernos de Direito Constitucional e Ciência Política. Instituto Brasileiro de Direito Constitucional, ano 6, n. 23, p. 28, São Paulo: RT, abr.-jun. 1998). 
quaisquer ingerências nas relações entre particulares, ao passo que, neste trabalho, pretende-se promover a defesa da ideia de que existe a possibilidade de responsabilizar aquele que prestou a informação, aconselhou ou recomendou a outrem, se desses atos resultar alguma espécie de dano que possa ser imputado a uma conduta dolosa, culposa ou até mesmo à quebra de uma legítima expectativa criada no declaratário, o que não pode ser respondido pela tradicional dicotomia responsabilidade contratual e extracontratual, mas sob uma ótica que permita antever a existência de uma terceira via em nosso ordenamento fundada no valor essencial da confiança.

Esse é exatamente o cerne de nossa tese, questão que será defendida ao longo dessas próximas páginas, quando voltaremos a tratar do tema atinente à autonomia da vontade e às suas limitações.

\subsubsection{A função social do contrato}

Nos dias de hoje as pessoas são obrigadas a contratar em diversas ocasiões de seu cotidiano, independentemente de sua capacidade financeira, padrão de vida ou condição social, o que demonstra a fundamental importância desse instrumento para o desenvolvimento da vida social. ${ }^{91}$

Contudo, as transformações da sociedade fizeram com que o contrato possua uma nova concepção, em que avulta a sua função social, bastante dissociada do individualismo voluntarista de antanho, em que o primado da tutela da autonomia da vontade sobrepunha-se ao interesse social e ao Estado não cabia interferir no domínio das relações de direito privado. ${ }^{92}$

91 "O mundo moderno é o mundo do contrato. E a vida moderna o é também, e em tão alta escala que se fizesse abstração por um momento do fenômeno contratual na civilização de nosso tempo, a consequência seria a estagnação da vida social. O homo economicus estancaria suas atividades. É o contrato que proporciona a subsistência de toda a gente. Sem ele, a vida individual regrediria, a atividade do homem limitar-se-ia aos momentos primários (Caio Mário da Silva Pereira, Instituições de direito civil: contratos. Declaração unilateral de vontade. Responsabilidade civil. 13. ed., rev. e atual. por Régis Fichtner, Rio de Janeiro: Forense, 2009, p. 10). 
Neste sentido, José de Oliveira Ascensão, ressalva que toda "atribuição jurídica deve ser realizada, também, para utilidade social e o exercício do direito não se pode fazer de maneira que essa destinação básica seja violada". ${ }^{93}$

Claudia Lima Marques ensina que essa nova acepção consiste em uma concepção social do contrato, para a qual importa principalmente os efeitos desse instrumento jurídico perante a sociedade e não só o momento da manifestação da vontade, pois a lei passa a "proteger determinados interesses sociais, valorizando a confiança depositada no vínculo, as expectativas e a boa-fé das partes contratantes". ${ }^{94}$

Dessa forma, não obstante constituir princípio fundamental para a efetividade dos contratos, a autonomia da vontade não deve ser exercida em desconformidade com o interesse social, posto encontrar-se limitada pelo que o ordenamento considera relevante: a tutela da dignidade da pessoa humana, o solidarismo e a construção de uma ordem jurídica socialmente justa.

Assim, em nosso ordenamento jurídico, o exercício da liberdade de contratar deve se efetivar em razão e nos limites da função social do contrato, nos termos do art. 421 do Código Civil. Além disso, em seu art. 2.035, parágrafo único, ${ }^{95} \mathrm{o}$ mesmo diploma civil traz disposição de importância fundamental para a disciplina contratual, ao estabelecer que nenhuma convenção poderá prevalecer se contrariar qualquer preceito de ordem pública especialmente aqueles que se referem à função social dos contratos e da propriedade.

\footnotetext{
${ }^{93}$ José de Oliveira Ascensão, Direito civil: teoria geral. Relações e situações jurídicas, Coimbra: Coimbra Ed., 2002, v. 3, p. 270.

94 Claudia Lima Marques, Contratos no Código de Defesa do Consumidor, 3. ed., São Paulo: RT, 1998, p. 101).

95 “Art. 2.035. A validade dos negócios e demais atos jurídicos, constituídos antes da entrada em vigor deste Código, obedece ao disposto nas leis anteriores, referidas no art. 2.045, mas os seus efeitos, produzidos após a vigência deste Código, aos preceitos dele se subordinam, salvo se houver sido prevista pelas partes determinada forma de execução. Parágrafo único. Nenhuma convenção prevalecerá se contrariar preceitos de ordem pública, tais como os estabelecidos por este Código para assegurar a função social da propriedade e dos contratos."
} 
Deste modo, o exercício da autonomia privada passa pelo crivo da função social, justificadora do sacrifício de direitos em prol do interesse da coletividade e do solidarismo social, constituindo-se um limite intrínseco para a liberdade de contratar. ${ }^{96}$

Em belo trabalho sobre o tema, Claudio Luiz Bueno de Godoy ressalva que a relevância da função social do contrato se concentra, antes de tudo, na promoção dos objetivos do Estado Social e na eficácia dos valores básicos do ordenamento, a dignidade da pessoa humana e a justiça social. ${ }^{97}$

Destarte, a intervenção estatal no âmbito das relações privadas se justifica para a garantia da dignidade humana e do bem estar social, assim como para a efetivação dos direitos sociais.

Neste contexto, Pietro Perlingieri observa que a tutela da dignidade humana e a busca pelo bem estar social demonstram a existência de dois vetores fundamentais do ordenamento, o personalismo e o solidarismo. Por personalismo entenda-se a opção prioritária pela pessoa, compreendida como "conexão existencial de cada indivíduo da estima de si, do cuidado com o outro e da aspiração de viver em instituições justas". Mas a pessoa é inseparável da solidariedade, que em uma perspectiva constitucional exprime a cooperação e a igualdade na afirmação dos direitos fundamentais de todos. ${ }^{98}$

Portanto, a função social concede ao magistrado poder para interpretar o contrato sob o prisma da tutela prioritária da pessoa e de sua dignidade, mas também em estreita consonância com o princípio da solidariedade social, objetivos fundamentais da

96 "Não se trata de aniquilar a autonomia privada, mas sim de superar o ciclo histórico do individualismo exacerbado, substituindo-o pela coexistencialidade. Quem contrata não mais contrata apenas com que contrata, eis aí o móvel que sinaliza, sob uma ética contratual contemporânea, para a solidariedade social". (Luiz Edson Fachin, Responsabilidade por dano de cumprimento diante do desaproveitamento da função social do contrato, in: Rosa Maria de Andrade Nery e Rogério Donnini (Coord.), Responsabilidade civil: estudos em homenagem ao professor Rui Geraldo Camargo Viana, São Paulo: RT, 2009, p. 317).

97 Cláudio Luiz Bueno de Godoy, Função social do contrato, 3. ed. São Paulo: Saraiva, 2009, p. 118119.

98 Pietro Perlingieri, $O$ direito civil na legalidade constitucional, tradução de Maria Cristina De Cicco, Rio de Janeiro: Renovar, 2008, p. 461-462. 
República, nos termos do art. 1. ${ }^{\circ}$, incisos III e IV $^{99}$ e do art. 3. ${ }^{\circ}$, inc. ${ }^{100}$ da Constituição Federal. Além disso, nossa Carta Magna expressa em seu artigo 170, caput $^{101}$, que a ordem econômica encontra-se fundada pela valorização do trabalho humano e na livre iniciativa, apresentado como finalidade o asseguramento de uma vida digna a todos, sob os ditames da justiça social, o que também constitui alicerce para a função social do contrato.

Sobre a tutela da pessoa, Claudio Luiz Bueno de Godoy, salienta que a dignidade humana possui um duplo aspecto: a) o primeiro, de índole negativa, consiste no dever pacífico genérico de respeito à pessoa humana, enquanto valor que lhe dá conteúdo; b) o segundo, de caráter positivo, significa proporcionar meios e modos que permitam ao ser humano "expandir as globalidades de sua personalidade, desenvolvê-la na totalidade de seus elementos". ${ }^{102}$

Por conseguinte, é possível verificar que o princípio da função social está intrinsecamente relacionado à base axiológica de nosso ordenamento jurídico, subordinando-se à relação contratual ao sistema de valores do direito brasileiro.

Contudo, a despeito de possuir uma base alicerçada no texto constitucional, além de previsão expressa no Código Civil a ressalvar a sua finalidade e relevância, a função social do contrato ainda é objeto de intensa controvérsia no que se refere à delimitação de seu conteúdo.

99 “Art. 1. ${ }^{\circ}$ A República Federativa do Brasil, formada pela união indissolúvel dos Estados e Municípios e do Distrito Federal, constitui-se em Estado Democrático de Direito e tem como fundamentos: I - a soberania; II - a cidadania; III - a dignidade da pessoa humana; IV - os valores sociais do trabalho e da livre iniciativa; V - o pluralismo político."

100 “Art. $3^{\text {o }}$. Constituem objetivos fundamentais da República Federativa do Brasil: I - construir uma sociedade livre, justa e solidária; II - garantir o desenvolvimento nacional; III - erradicar a pobreza e a marginalização e reduzir as desigualdades sociais e regionais; IV - promover o bem de todos, sem preconceitos de origem, raça, sexo, cor, idade e quaisquer outras formas de discriminação."

101 “Art. 170. A ordem econômica, fundada na valorização do trabalho humano e na livre iniciativa, tem por fim assegurar a todos existência digna, conforme os ditames da justiça social, observados os seguintes princípios: (...)."

102 Cláudio Luiz Bueno de Godoy, Função social do contrato, cit., p. 126. 
Nesse sentido, Antonio Junqueira de Azevedo e Francisco Paulo de Crescenzo Marino, atualizando a obra do mestre Orlando Gomes, assinalam a existência de duas correntes distintas, uma a defender a proteção de interesses externos às partes contratantes como limitação ao disposto no art. 421 do Código Civil e outra a vislumbrar no princípio da função social do contrato outras aplicações práticas. Pela primeira, existiriam interesses institucionais, tais como o meio-ambiente e a defesa da concorrência, caracterizados pelos interesses de determinados grupos sociais e que seriam juridicamente distintos dos interesses individuais. O limite da função social do contrato consistiria na lesão a direitos institucionais externos ao contrato, negando-se a possibilidade de se recorrer a esse princípio para solucionar algumas das vicissitudes ligadas apenas à relação entre os contratantes. ${ }^{103}$

Pela segunda corrente, que é a defendida pelos atualizadores do grande mestre baiano, a função social pode levar à ineficácia superveniente do contrato em pelo menos três casos: a) a ofensa a interesses coletivos (meio ambiente, concorrência, etc.); b) a lesão à dignidade da pessoa humana, que estaria prevista, inclusive pelo enunciado aprovado na I Jornada de Direito Civil promovida pelo Centro de Estudos Judiciários do Conselho da Justiça Federal ${ }^{104}$; e c) a impossibilidade de obtenção do fim último do contrato, que faz com que o contrato pêra sua função social, tornando-se juridicamente ineficaz, se o seu fim último não puder ser alcançado, o que também foi reconhecido por enunciado ${ }^{105}$ aprovado na III Jornada de Direito Civil do Conselho da Justiça Federal. ${ }^{106}$

Defendendo uma eficácia inter partes do princípio em comento, Claudio Luiz Bueno de Godoy ressalva que o contrato possui uma função social que se projeta, em primeiro lugar, entre as próprias partes, ainda que se projete igualmente sobre o

\footnotetext{
103 Orlando Gomes, Contratos, cit., p.37.

104 Enunciado n. 23 da I Jornada de Direito Civil do CJF: "Art. 421: a função social do contrato, prevista no art. 421 do novo Código Civil, não elimina o princípio da autonomia contratual, mas atenua ou reduz o alcance desse princípio quando presentes interesses metaindividuais ou interesse individual relativo à dignidade da pessoa humana".

105 Enunciado n. 23 da I Jornada de Direito Civil do CJF: “A frustração do fím do contrato, como hipótese que não se confunde com a impossibilidade da prestação ou com a excessiva onerosidade, tem guarida no Direito brasileiro pela aplicação do art. 421 do Código Civil”.
}

106 Orlando Gomes, Contratos, cit., p. 37-38. 
corpo social e a bem do próprio desenvolvimento da sociedade, atendendo à promoção dos valores constitucionais que, a priori, lhe digam respeito. ${ }^{107}$

Nesse mesmo sentido, Teresa Negreiros salienta que o contrato não pode mais ser concebido através de uma leitura individualista, de acordo com a qual só existiriam limites externos, confins para além dos quais se concede aos contratantes um salvo-conduto para o exercício da liberdade contratual de forma absoluta, à maneira oitocentista. Pelo contrário, deve se reforçar a idéia de que a "funcionalização é inerente à situação jurídica, conformando-a em seus aspectos, qualificando-a em sua natureza e disciplina", o que demonstra o equívoco da concepção da função social como algo contraposto ao direito subjetivo e capaz de delimitá-lo apenas externamente. ${ }^{108}$

Esse, também, é o nosso entendimento, no sentido de que a função social não representa apenas um limite externo ao contrato, muito embora sua atuação no âmbito dos interesses metaindividuais seja de extrema relevância e absolutamente necessária.

Em nossa opinião, a atuação da função social também se projeta para a relação entre as partes, intrínseca ao contrato, como instrumento limitador da autonomia da vontade, com vistas à concretização dos valores que constituem a base axiológica de nosso ordenamento.

Assim, consoante ressalva Gérson Luiz Carlos Branco, o grande desafio enfrentado pela aplicação do disposto no art. 421 do Código Civil consiste em se coadunar o contrato enquanto instrumento para a realização dos interesses das partes, respeitando-se ao mesmo tempo os valores determinados por imperativos sociais. ${ }^{109}$

\footnotetext{
107 Cláudio Luiz Bueno de Godoy, Função social do contrato, cit., p. 134.

108 Teresa Negreiros, Teoria do contrato: novos paradigmas, 2. ed., Rio de Janeiro: Renovar, 2006, p. 210-211.

109 Gerson Luiz Carlos Branco, Função social dos contratos: interpretação a luz do Código Civil, São Paulo: Saraiva, 2009, p. 304.
} 
Por conseguinte, a função social possui um âmbito de projeção intrínseco ao contrato, também conhecido por eficácia interna, que conforma e qualifica os limites da relação contratual. Porém, também se projeta para além do contrato, em sua eficácia externa, constituindo uma limitação aos interesses individuais e à autonomia da vontade toda vez em que se fizer necessária a tutela dos interesses metaindividuais.

\subsubsection{A boa-fé objetiva}

O princípio da boa-fé objetiva permeia-se por todas as relações jurídicas da sociedade, apresentando importância fundamental para o desenvolvimento das relações entre particulares em nosso sistema de direito privado, assim como para a construção de uma ordem jurídica justa e solidária.

O estudo de referido princípio, bem como de base axiológica fundada na confiança, apresenta destacada relevância para o deslinde de nossa tese, razão pela qual o tema será tratado no próximo capítulo. 


\section{2}

\section{A TEORIA DA CONFIANÇA E O PRINCÍPIO DA BOA-FÉ OBJETIVA COMO BASE FUNDAMENTAL PARA O DESENVOLVIMENTO DAS RELAÇÕES ENTRE PARTICULARES EM NOSSO SISTEMA DE DIREITO PRIVADO}

\subsection{A teoria da confiança e o seu fundamento ético-jurídico}

No que concerne ao tema objeto do presente estudo, a preservação da confiança demanda cuidadosa e apurada análise da situação concreta e das expectativas criadas pelos responsáveis por informações, conselhos e recomendações, assim como pelas representações que seus interlocutores apresentem por efetivas. Dessa investigação pode-se chegar à necessidade de se impor a alguém que assegure a expectativa criada por outrem, ou, por outro lado, indenize-o pelos danos causados em virtude de sua frustração. Será possível, ainda, verificar-se que da relação intersubjetiva não se caracterizou a quebra da confiança, hipótese em que inexistiria violação a dever jurídico.

Como se vê, a tutela da confiança apresenta um destacado fundamento ético, ${ }^{110}$ enquanto valor fundamental das relações privadas, cristalizado na forma de proteção das expectativas, o que se manifesta, por exemplo, na proibição do

110 Para Karl Larenz, “o princípio da confiança apresenta um elemento componente de ética jurídica e outro que se orienta através da segurança no tráfego jurídico. Um e outro não podem se separar. O componente de ética jurídica ressoa somente na medida em que a criação da aparência jurídica tenha que ser imputada àquele em cuja desvantagem se produz a proteção do que confiou. Em troca, o componente ético-jurídico está em primeiro plano no princípio da boa-fé. Dito princípio consagra que uma confiança despertada de um modo imputável deve ser mantida quando efetivamente nela acreditaram. A suscitação da confiança é 'imputável' quando aquele que a suscita sabia ou teria que saber que o outro iria confiar". No original: "El principio de la confianza tiene un elemento componente de Ética jurídica y otro que se orienta hacia la seguridad del trafico. Uno y otro no se pueden separar. El componente de Ética jurídica resuena sólo en la medida en que la creación de la apariencia tiene que ser imputable a aquel en cuya desventaja se produce la protección del que confió. En cambio, el componente ético-jurídico está en primer plano en el principio de buena fe. Dicho principio consagra que una confianza despertada de un modo imputable debe ser mantenida cuando efectivamente se ha creído en ella. La suscitación de la confianza es 'imputable' cuando el que la suscita sabía o tenía de saber que el otro iba a confiar" (Derecho justo. Fundamentos de etica jurídica, tradução de Luiz Díez-Picazo, Madrid: Civitas, 2001, p. 95-96). 
comportamento contraditório (venire contra factum proprium) ou nas hipóteses de neutralização do direito ${ }^{111}$ - a supressio.

Na visão de Claus-Wilhelm Canaris há que se falar em uma tutela das expectativas por necessidade ético-jurídica, pois a ordem jurídica não poderia deixar de conferir relevância às expectativas, ainda que se trate de hipóteses que não correspondam a um regime jurídico preciso e objetivo, a fim de se promover condições essenciais para uma justa composição das posições e dos interesses dos sujeitos de uma relação jurídica. $^{112}$

Assim, ressalta-se a base ético-jurídica ${ }^{113}$ da confiança, posto a complexidade e dinâmica das relações intersubjetivas não serem acompanhadas pelo ordenamento positivo em sua plenitude, tornando imperiosa a proteção das expectativas e permitindo que a convivência social se desenvolva em um terreno pautado pela eticidade, pelo solidarismo e pela tutela da pessoa.

Não se pode, porém, dissociar a proteção confiança da ideia de segurança no tráfego jurídico, evidenciando-se a espinhosa tarefa de se chegar a um bom termo que

111 É de Manuel Antonio de Castro Portugal Carneiro da Frada a ressalva para que se considere a locução "neutralização do direito", pois "a expressão escapa a algumas objeções de que padecem certas alternativas e é também menos comprometida que supressio ao não apontar, ao invés desta última, para a extinção do direito, apresentando-se compatível com uma simples paralisação do seu exercício" (Teoria da confiança e responsabilidade civil, Coimbra: Almedina, 2004, p. 63 - em nota de rodapé).

112 Claus-Wilhelm Canaris, Die Vertrauenshaftung im deutschen Privatrecht, München: Beck Verlag, 1971 (reimpr. Nendeln, 1981), p. 266 ss. e 528 e ss., apud Manuel Antonio de Castro Portugal Carneiro da Frada, Teoria da confiança e responsabilidade civil, cit., p. 62-63.

113 "O qualificativo ético-jurídico significa que este tipo de responsabilidade pela confiança se situa para além das formas que as regras do ius strictum permitem, assumindo uma intencionalidade mais profunda e material, a tocar de fato os fundamentos e implicações últimas da juridicidade. Trata-se portanto de uma proteção que se pode dizer imposta por indeclináveis exigências da convivência humana e de sua ordenação pelo Direito, requerida por um princípio jurídico (ou ético-jurídico) fundamental que transcende, pela sua própria natureza, as decisões e a oportunidade de positivação por parte do legislador. No domínio da proteção das expectativas a ética é sem dúvida uma realidade particularmente próxima, dada a compenetração daquelas com virtudes pessoais como a veracidade e a fiabilidade. Mas isso não afasta que estejamos perante uma realidade especificamente jurídica. Deverá é não esquecer-se a inaceitabilidade da separação radical entre Direito e Moral, levada, a cabo por vários positivismos e "normativismos"” (Manuel Antonio de Castro Portugal Carneiro da Frada, Teoria da confiança e responsabilidade civil, cit., p. 62-63). 
signifique "a revalorização da confiança como valor preferencialmente tutelável no trânsito jurídico", ${ }^{114}$ sem que isso represente uma disjunção com o sistema.

De fato, quando as ações humanas ou suas atividades criam justas expectativas em outrem, levando à tomada de posições ou à realização de investimentos, torna-se necessária a tutela de referida expectação, a fim de se garantir a segurança no tráfego interindividual, tarefa essencial do Direito, na prevenção e solução de conflitos.

Isso porque, como bem ensina Antonio Junqueira de Azevedo, o Direito não significa apenas a norma, mas é, antes de tudo, sistema. E de segunda ordem, enquanto instrumento da sociedade para dirimir e prevenir conflitos. Dessa forma, incorpora-se a vida social, o sistema maior - de primeira ordem -, passando a se justificar via interpretação, e não somente pela lei do maior número, mas por "todo um processo de argumentação "sensível à verdade"" no dizer de Habermas - que preferimos dizer "processo de argumentação sensível ao que é socialmente útil" -, "dando mais legitimidade à própria Constituição e às leis em geral". ${ }^{115}$

Como valor essencial para a vida em sociedade a confiança representa, também, a segurança necessária para o desenvolvimento das relações humanas. ${ }^{116}$ Assentadas neste patamar de fidúcia e segurança é que as pessoas se relacionam, tomam decisões, assumem posições jurídicas, investem, enfim, realizam a experiência da vida.

Consoante bem adverte Karl Larenz, a ideia de uma segurança garantida pelo Direito é fundamental para a vida social, posto que o desaparecimento da

114 Luiz Edson Fachin, O aggiornamento do direito civil brasileiro e a confiança negocial, Repensando fundamentos do direito civil brasileiro contemporâneo, Rio de Janeiro: Renovar, 1998, p. 115.

115 Antonio Junqueira de Azevedo, Novos estudos e pareceres de direito privado. "O direito ontem $\mathrm{e}$ hoje. Crítica ao neopositivismo constitucional e insuficiência dos direitos humanos", São Paulo: Saraiva, 2009, p. 11.

116 Neste sentido, Roberto Senise Lisboa observa que "a confiança pode ser encontrada no sistema jurídico como valor fundamental consecutivo da segurança" (Da confiança como valor fundamental e princípio geral do negócio jurídico, 2009, Tese (Concurso de Professor Titular de Direito Civil da Faculdade de Direito da Universidade de São Paulo), p. 124). 
confiança, enquanto um modo geral de comportamento, acarreta a insegurança em todo o tráfego interindividual, o que seria altamente prejudicial para o convívio social. ${ }^{117}$

Por outro lado, ressalvada sua base ético-jurídica e a sua estreita correlação com a segurança no tráfego, faz-se necessário salientar que a proteção positiva da confiança, consubstanciada pela preservação da posição do confiante, apresenta correspondência direta com a teoria do negócio jurídico, o que se demonstrará no item seguinte.

\subsection{A confiança e as teorias fundamentadoras do negócio jurídico}

O reconhecimento do princípio da confiança representa uma ruptura com a teoria voluntarista tradicional, em que se privilegia a vontade do sujeito e a sua intenção, protegendo-se os interesses do declarante em detrimento das expectativas que possam ter sido criadas no destinatário ou das repercussões decorrentes da declaração junto aos interesses das diversas pessoas que, porventura, sofram os seus reflexos. ${ }^{118}$

Dessa forma, ganha relevo o prisma social do negócio jurídico, caracterizando-se o afastamento da vetusta concepção voluntarista, altamente subjetiva e fundada na busca da real intenção do declarante, para se afirmar o necessário interesse da sociedade no que tange aos efeitos decorrentes dessa declaração de vontade. ${ }^{119}$

117 No original: "Quien defrauda la confianza que ha producido o aquella a la que ha dado ocasión a otro, especialmente a la otra parte en un negocio jurídico, contraviene una exigencia del Derecho con independencia de cualquier mandamiento moral - tiene que ponerse a sí mismo porque la desaparición de la confianza, pensada como un modo general de comportamiento, tiene que impedir y privar de seguridad al tráfico interindividual. Aquí entra en juego la idea de una seguridad garantizada por el Derecho, que en el derecho positivo se concretiza de diferentes maneras" (Karl Larenz, Derecho justo. Fundamentos de etica jurídica, cit., p. 91).

118 Nesse sentido, ressalva Anderson Schreiber que "o reconhecimento da necessidade de tutela da confiança desloca a atenção do direito, que deixa de se centrar exclusivamente sobre a fonte das condutas para observar também os efeitos práticos da sua adoção. Passa-se da obsessão pelo sujeito e pela sua vontade individual, como fonte primordial das obrigações, para uma visão que, solidária, se faz atenta à repercussão externa dos atos individuais sobre os diversos centros de interesses, atribuindo-lhes eficácia obrigacional independentemente da vontade ou da intenção do sujeito que os praticou" (A proibição de comportamento contraditório. Tutela da confiança e venire contra factum proprium, 2. ed., Rio de Janeiro: Renovar, 2007, p. 94).

119 Ao definir o negócio jurídico através de sua estrutura, Antonio Junqueira de Azevedo assinala o afastamento das concepções voluntaristas, para afirmar a perspectiva social e não psicológica do 
O tema é particularmente importante para o desenvolvimento da presente tese, eis que a difusão da informação através da linguagem e a produção de efeitos jurídicos, dela decorrentes, trazem consigo toda a controvérsia relativa às teorias da vontade e da declaração, assim como àquelas relacionadas à teoria da responsabilidade, da aparência e da confiança.

Essencialmente subjetiva, a teoria voluntarista (Willenstheorie) imperou no século XIX, fundando seus alicerces na ideia de que a vontade real, ou vontade verdadeira, ${ }^{120}$ deve prevalecer sobre a vontade declarada, pois só a primeira deve produzir efeitos de direito, em nítido privilégio à figura do declarante e consequente prejuízo ao declaratário, obrigado a perquirir sobre a real intenção do responsável pela manifestação volitiva. ${ }^{121}$

$\mathrm{Na}$ França, a teoria da vontade ganhou importância e relevo, fazendo com que seus doutrinadores propalassem a ideia de que, entre a vontade e a declaração, a lei francesa preferiu a primeira. ${ }^{122}$ Fruto do individualismo levado a extremos através dos ideais liberais trazidos pela Revolução Francesa de 1789, o voluntarismo recebe a primazia no tratamento por parte do legislador, justificando-se na vontade do declarante o efeito jurídico a ser produzido pelo negócio. ${ }^{123}$

negócio: "Quer-nos parecer que uma concepção estrutural do negócio jurídico, sem repudiar inteiramente as concepções voluntaristas, dela se afasta, porque não se trata mais de entender por negócio um ato de vontade do agente, mas, sim um ato que socialmente é visto como ato de vontade destinado a produzir efeitos jurídicos. A perspectiva muda inteiramente, já que de psicológica passa a social. O negócio não é o que o agente quer, mas sim o que a sociedade vê como a declaração de vontade do agente. Deixa-se, pois, de examinar o negócio através da ótica estreita de seu autor e, alargando-se extraordinariamente o campo de visão, passa-se a fazer o exame pelo prisma social e mais propriamente jurídico" (Negócio jurídico: existência, validade e eficácia, 4. ed., São Paulo: Saraiva, 2002, p. 21).

120 Antonio Junqueira de Azevedo, em comentários acerca da teoria subjetivista, ressalva que o seu sistema, "colocado em relevo sobretudo por Savigny, faz prevalecer, em todos os casos, a vontade verdadeira do declarante, de vez que é somente essa vontade que deve produzir os efeitos de direito que estão em causa, sistema designado pelo nome de teoria da vontade, ou seja, da predominância da vontade como dogma absoluto" (Negócio jurídico: existência, validade e eficácia, cit., p. 74).

121 "Para a primeira, subjetiva, voluntarista, de Savigny e seus imediatos seguidores (Windscheid, Dernburg, Oetermann, Ennecerus), o negócio jurídico é essencialmente vontade, a que deve corresponder exatamente a sua forma de declaração, que é simples instrumento de manifestação dessa vontade. Essa teoria protege naturalmente os interesses do declarante. Por isso, todas as questões acerca da formação ou do conteúdo do ato levam à pesquisa da real intenção do agente" (Francisco Amaral, Direito civil: Introdução, 7. ed., Rio de Janeiro: Renovar, 2008, p. 393). Antonio Junqueira de Azevedo, Negócio jurídico: existência, validade e eficácia, cit., p. 76.

123 "A mesma concepção individualista, que inspira o dogma da vontade, leva, inconscientemente (como acontecia no direito justinianeu), a procurar a justificação do efeito jurídico a obter, na 
Assim, o negócio jurídico seria conceituado como uma manifestação de vontade destinada a produzir determinados efeitos jurídicos, definição que se tornou clássica e foi largamente difundida ao longo dos tempos, mas não ficou alheia às críticas, eis que privilegia o aspecto interno da vontade e não a sua exteriorização. ${ }^{124}$

$\mathrm{Na}$ Alemanha, por sua vez, questionava-se a importância concedida à vontade negocial, ainda nos finais do século XIX, pois, passados quase cem anos do Código Civil francês de 1804, já era possível vislumbrar as vicissitudes da teoria voluntarista. Surge, então, em contraponto ao dogma da vontade, a teoria da declaração (Erklärungstheorie), em que se passa a proteger a posição do destinatário da manifestação volitiva, independentemente de existir uma correspondência com a vontade real do declarante. ${ }^{125}$

Nesses casos, a declaração pode apresentar um sentido diverso daquele pretendido pelas partes, e, mesmo assim, prevalecer, posto ser o seu sentido, e não a vontade real do declarante, a razão determinante para a produção de efeitos jurídicos. ${ }^{126}$

vontade daquela pessoa a cargo ou em proveito da qual se produz, ou de cuja atividade ele irradia, e dessa maneira, leva a exagerar o contributo que a vontade individual dá à produção daquele efeito, fazendo descobrir ou procurar nela a sua razão exclusiva precípua" (Emilio Betti, Teoria geral do negócio jurídico, tradução de Fernando de Miranda, Coimbra: Coimbra Ed., 1969, t. I, p. 116).

124 Em crítica ao conceito de negócio jurídico enquanto manifestação de vontade destinada à produção de efeitos jurídicos Emilio Betti afirma que "esta qualificação formal, frágil e incolor, inspirada no 'dogma da vontade', não lhe apreende a essência, a qual está na autonomia, no auto-regulamento de interesses nas relações privadas como fato social: auto-regulamento, portanto, que o particular não deve limitar-se a desejar, a 'querer', na esfera interna da consciência, mas antes a preparar, ou seja, a realizar objetivamente" (Teoria geral do negócio jurídico, cit., p. 112).

125 “A grande importância que a ciência do Direito no final do século XIX concedeu à vontade negocial foi questionada, no entanto, ainda durante os trabalhos legislativos do BGB. Já em 1875, Bähr exigiu que, no caso de um erro do declarante, este precisaria manter sua declaração, pois o destinatário da declaração deveria ser protegido por sua confiança na permanência da declaração. Ao se concordar com esta concepção, aceita-se que existem, aparentemente, negócios jurídicos onde não a vontade, que neste caso, devido ao erro, está ausente, mas sim, que apenas o suporte fático externo da declaração origina a conseqüência. O ponto de vista de Bähr foi, logo a seguir, designado como 'teoria da declaração' ('Erklärungstheorie')" (Jan Schapp, Introdução ao direito civil, tradução de Maria da Glória Lacerda Rurack e Klaus-Peter Rurack, Porto Alegre: Sergio Antonio Fabris, 2006, p. 228).

126 Antonio Junqueira de Azevedo ressalva que o sistema fundado na teoria da declaração "faz prevalecer a vontade, mesmo fictícia, que se infere da declaração, sobre a vontade verdadeira, seja porque o sentido normal da vontade somente existe, do ponto de vista do direito, por sua expressão externa e somente há lugar para se aplicarem, às disposições da vontade privada, as regras de interpretação admitidas para as normas legais e disposições de lei (cf. Danz, 'Auslegung der Rechtgeschafte', pág. 48), seja porque quem emite uma declaração jurídica aceita se prender, em face de quem ele se dirige, pelo sentido normal das expressões que emprega" (Negócio jurídico: existência, validade e eficácia, cit., p. 76). 
Por conseguinte, importa a declaração da vontade, prevalecendo o aspecto volitivo exteriormente declarado ao aspecto psicológico caracterizado pela real intenção do declarante.

Contudo, não se deve chegar à singela conclusão de que o sistema francês é eminentemente voluntarista, ao passo que o germânico privilegia a declaração volitiva em detrimento da vontade real do declarante. Nesse sentido, ensina Antonio Junqueira de Azevedo que as diferenças entre os direitos dos dois países não são tão grandes, posto inexistir, a priori, uma tomada de posição em favor de uma ou de outra teoria. ${ }^{127}$

Com efeito, é possível verificar na legislação francesa, assim como na alemã, dispositivos que ora privilegiam a vontade real e interna do declarante, ora tutelam a vontade externada. Além disso, poucos não são os doutrinadores germânicos partidários da doutrina voluntarista, como é o caso de Windscheid, bem como os franceses a abraçar a teoria objetiva, como Saleilles. O mesmo se diga da interpretação jurisprudencial dos dois países. ${ }^{128}$

O fato é que ambas as teorias não se demonstram as mais adequadas para lograr uma correta definição do negócio jurídico, apresentando, cada qual, suas devidas limitações e lacunas, por vezes intransponíveis. ${ }^{129}$

Nesse contexto, Emilio Betti, em crítica aberta à teoria voluntarista, salienta que, enquanto fato psicológico meramente interno, a vontade pertence unicamente ao foro íntimo da consciência individual, como uma coisa em si mesma incompreensível e incontrolável. Desse modo, somente quando se tornar reconhecível no ambiente social,

127 Antonio Junqueira de Azevedo, Negócio jurídico: existência, validade e eficácia, cit. p. 77.

128 Sobre o tema, ver, por todos, Antonio Junqueira de Azevedo, Negócio jurídico: existência, validade e eficácia, cit., p. 74-87.

129 “As diferenças entre a vontade psicológica e a vontade exteriorizada são sempre possíveis de ocorrer. E, parece claro, não se pode, simplesmente, estabelecer aprioristicamente, o que deve prevalecer: se a vontade ou se a sua declaração. Sobre esse problema as duas principais correntes doutrinárias que procuram explicar o negócio jurídico (especialmente) não têm posições uniformes: a) para a teoria da vontade (teoria subjetiva), na configuração do negócio jurídico o que importa é a vontade em si, portanto, o conteúdo da vontade, aquilo que, psicologicamente, se quis; b) os seguidores da teoria da declaração (teoria objetiva) entendem, diferentemente, que a prevalência deve ser da vontade tal qual exteriorizada, sem levar-se em conta a vontade real" (Marcos Bernardes de Mello, Teoria do fato jurídico: plano da existência, 15. ed., São Paulo: Saraiva, 2008, p. 149). 
seja através de comportamentos, seja por intermédio de declarações, passará a ser um fato social e, por essa razão, capaz de poder constituir um objeto de valoração e de interpretação ou um instrumento de autonomia privada. ${ }^{130}$

Essa exigência de recognoscibilidade no âmbito da vida social é fundamental para que o negócio possa produzir os seus devidos efeitos jurídicos, posto que o direito exerce uma função ordenadora das relações intersubjetivas essencial ao desenvolvimento do organismo social e da qual não pode estar dissociado. Exigir que o destinatário da declaração tenha ciência da verdadeira intenção do declarante seria obrigar o declaratário a conhecer aspectos psicológicos do declarante que jamais foram exteriorizados, o que, obviamente, comprometeria toda a dinâmica da vida social e das relações interpessoais.

O ato volitivo que importa para a definição do negócio jurídico não se limita a representar mera manifestação da vontade psicológica do declarante, mas representa uma forma de conduta em que a pessoa ordena suas relações com outrem, cuja possibilidade de ser reconhecida é essencial para a vida social, de modo que sua exteriorização permita ao destinatário verificar quais canais jurídicos são pretendidos em razão dessa vontade que está sendo externada. ${ }^{131}$

Como contraponto ao dogma da vontade, a teoria da declaração fundamenta-se no primado da vontade declarada em detrimento da vontade interna do declarante. Como consequência, a divergência entre a vontade exteriorizada e aquela efetivamente desejada não apresenta importância, pois aquilo que foi declarado é o que deve prevalecer para a tutela dos interesses do destinatário, bem como para a preservação da segurança do tráfego jurídico.

Levada a extremo, a teoria objetivista também pode ser fonte de incongruências e de lacunas, da mesma forma com o que ocorre com a teoria

\footnotetext{
130 Emilio Betti, Teoria geral do negócio jurídico, cit., p. 109.

131 Como bem assevera Antonio Junqueira de Azevedo, "a declaração, uma vez feita, desprende-se do iter volitivo; adquire autonomia, como a obra se solta de seu autor. É da declaração e não da vontade que surgem os efeitos. Tanto é assim que, mesmo quando uma das partes, em um contrato, muda de idéia, persistem os efeitos deste" (Negócio jurídico: existência, validade e eficácia, cit., p. 85).
} 
subjetivista, o que resta evidenciado, por exemplo, na hipótese de regulamentação do erro. Em uma leitura extremada da teoria da vontade o negócio eivado de erro seria nulo, posto encontrar-se em situação dissonante com a vontade real do declarante, pouco importando a posição do destinatário ou a existência de terceiros de boa-fé.

De outro modo, aplicando-se radicalmente a teoria da declaração, o negócio seria de todo válido - se de boa-fé o declaratário -, posto importar apenas a vontade exteriorizada e a garantia de segurança nas relações jurídicas. ${ }^{132}$

Como se vê, ambas as teorias firmam suas bases na vontade como elemento do negócio jurídico, opondo-se no fato de ser a vontade interior que deve prevalecer, caso da teoria voluntarista, ou no primado da vontade exteriorizada, hipótese da teoria declarativa.

Nos dois casos, no entanto, não apresentam soluções plenamente satisfatórias para a conceituação do negócio jurídico, abrindo espaço para o surgimento de teorias intermediárias, como é o caso da teoria da responsabilidade, da teoria da aparência e da teoria da confiança.

Pela teoria da responsabilidade ${ }^{133}$ reconhece-se que a declaração pode ter efeito obrigatório, ainda que dissociada da vontade, se a divergência entre a vontade declarada e a real decorre da culpa do declarante, hipótese em que ficará responsável pelo desacordo entre a vontade e a declaração.

132 Para Francisco Amaral "ambas as teorias são inaceitáveis em suas posições extremas, que seriam, quanto à eventual divergência entre a vontade e a declaração, no caso da teoria subjetiva, a nulidade do negócio, e no caso da objetiva, a validade, desde que de boa-fé o destinatário" (Direito civil: introdução, 7. ed., cit., 2008, p. 393).

133 "O princípio da responsabilidade foi introduzido por Scialoja, em comentário ao Direito Romano, depois aperfeiçoado por outros autores e aplicado ao Direito atual. Em regra, a declaração deve exprimir uma vontade efetiva, sem o que não possui validade; mas o declarante não poderá prevalecer-se do dissídio todas as vezes que lhe seja imputável, provindo de culpa sua. Se o sujeito intencionalmente disse o que não queria, ou se podia evitar o desacordo usando de maior diligência, o contrato será válido, em vista de sua responsabilidade. Não basta porém essa condição positiva; é necessária outra mista; deve haver culpa por parte do declarante e ausência de culpa da parte do declaratário" (Inocêncio Galvão Telles, Manual dos contratos em geral, 4. ed., Coimbra: Coimbra Ed., 2002, p. 160). 
Assim, consoante ensina Silvio Rodrigues, o declarante que erra, devido a sua própria culpa ou dolo, fica responsável com relação àqueles que confiaram na legitimidade de seu ato. ${ }^{134}$

Já a teoria da aparência, como bem assinala Roberto Senise Lisboa, "pode ser sintetizada no fenômeno do parecer sem ser". Com o seu gérmen idealizado para situações jurídicas relacionadas à posse e à propriedade, com o tempo a aparência passou a ser utilizada em prol da segurança e da agilidade no tráfego jurídico. Apresenta como requisitos para a proteção do terceiro através da aparência $i$ ) uma relação de causalidade entre a conduta esperada e a expectativa frustrada; ii) o conhecimento de um Tatbestand de aparência e iii) o desconhecimento da situação real. ${ }^{135}$

A teoria da aparência demanda a existência de uma previsão normativa, a fim de que o sujeito que desconhece a situação real pudesse ser colocado em uma posição que seria tutelável caso esse fato aparente correspondesse à realidade, tutelando-se, por conseguinte, a credibilidade decorrente de um fato aparente e a sua inserção no sistema como forma necessária de garantir a segurança no tráfego jurídico.

Neste sentido, Carneiro da Frada ressalva a maior objetivação do regime da aparência, em que se transcende das diversas particularidades do caso concreto em direção "a ponderações mais gerais ligadas às condições de funcionamento e às exigências do comércio jurídico como um todo". ${ }^{136}$

A teoria da confiança, por sua vez, apresenta uma menor objetivação do que a teoria da aparência e expande os seus fundamentos para além dos limites da vontade interior (teoria subjetiva) ou da vontade declarada (teoria objetiva), posto fundar as suas bases na confiança despertada pela declaração de vontade.

\footnotetext{
134 Silvio Rodrigues, Dos vícios do consentimento, 3. ed., São Paulo: Saraiva, 1989, p. 34.

135 Roberto Senise Lisboa, Da confiança como valor fundamental e princípio geral do negócio jurídico, cit., p. 70-71.

136 Manuel Antonio de Castro Portugal Carneiro da Frada, Teoria da confiança e responsabilidade civil, cit., p. 47.
} 
No entanto, a confiança permeia-se nas relações intersubjetivas de forma mais dinâmica do que a aparência, eis que a segunda demanda a existência de uma situação objetivamente prevista pela norma, suscetível de conceder proteção àquela posição assumida pelo sujeito que desconhece a situação real e pauta-se por aquela que está aparente, enquanto a primeira não está ligada necessariamente a uma previsão normativa específica, mas, antes de tudo, às relações pessoais e individualizadas que podem apresentar-se afastadas de um tipo jurídico previamente identificado.

$\mathrm{Na}$ verdade, a teoria da confiança consistiria em uma solução intermediária entre as teorias subjetiva e objetiva, eis que fundamentada pela ideia de que o destinatário deposita a sua confiança na vontade declarada enquanto manifestação de uma vontade interior. ${ }^{137}$ Essa legítima crença na vontade declarada ${ }^{138}$ como manifestação de uma vontade real seria fundamental para a tomada de posição do declaratário, incutindo-lhe uma confiança que seria merecedora de tutela e consistiria na base do negócio jurídico.

Em nossa opinião, contudo, nenhuma das teorias supracitadas é capaz de definir conceitualmente o negócio jurídico, pois, partilhando do ensinamento de Antonio Junqueira de Azevedo, entendemos que o cerne do problema encontra-se na premissa equivocada de que a vontade consistiria em elemento do negócio jurídico, enquanto o negócio consiste apenas na declaração da vontade. De fato, o processo volitivo interno não faz parte do negócio, ainda que tenha importância para a emissão da declaração, pois é essa última que apresenta relevância para que o primeiro venha a existir no plano jurídico. A vontade interna, consistente nas representações psicológicas

137 "O destinatário da declaração confia na declaração, não como uma ocorrência sensorialmente perceptível, e sim, vê nela, ao contrário, a expressão manifesta de uma vontade interior, que é o ponto de referência de sua confiança. Visto desta forma, o princípio da vontade e o princípio da declaração podem referir-se mutuamente. Não parece apropriada uma disputa excludente entre os dois princípios" (Jan Schapp, Introdução ao direito civil, cit., p. 231).

138 Em comentários acerca da teoria da confiança, Vicente Ráo assevera que a vontade declarada "só prevalece, em caso de conflito com a vontade real, ou só substitui a vontade inexistente quando no destinatário houver suscitado um grau tal de confiança que ele, com razão e levando em conta as circunstâncias objetivas do caso, tenha acreditado na normalidade da declaração, procedendo, em conseqüência, de acordo com essa crença legítima. É um fundamento social que, na hipótese, confere predominância à declaração" (Ato jurídico, 4. ed., São Paulo: RT, 1997, p. 172). 
do declarante, pode ter influência na validade ou eficácia do negócio, mas não para sua existência. $^{139}$

Por essa razão, a teoria da confiança não será abordada na presente tese como fundamento para a conceituação do negócio jurídico ou como solução para a secular controvérsia acerca da predominância da vontade ou da declaração, mas como alicerce necessário para o desenvolvimento das relações entre particulares.

Com efeito, o tema da confiança possui inegável importância para o trabalho, enquanto valor fundamental para o incremento das relações humanas, especialmente no que tange às trocas de informações entre sujeitos. Trata-se de valor essencial para a convivência social, bem como para o desenvolvimento das interações entre sujeitos, além de manifestação emblemática do solidarismo social.

Por conseguinte, a proteção da confiança apresenta estreita correlação com um sistema que respeite seus valores fundamentais, tutele as justas expectativas decorrentes das relações jurídicas materiais e em que impere um padrão de conduta ético e probo. Trata-se dos vetores essenciais à projeção do princípio da boa-fé objetiva, consoante restará evidenciado nos itens seguintes.

\subsection{O princípio da boa-fé objetiva}

Hodiernamente, consagrou-se no ordenamento jurídico pátrio o princípio normativo da boa-fé objetiva, muito embora, em tempos mais remotos, imperasse a tutela do estado psicológico da pessoa, consubstanciada pela prevalência da boa-fé subjetiva, a chamada "boa-fé crença", em que se perquiria acerca do estado anímico do sujeito e da ciência do fato de que sua conduta seria lesiva ou contrária ao direito. ${ }^{140}$

\footnotetext{
139 Antonio Junqueira de Azevedo, Negócio jurídico: existência, validade e eficácia, cit., p. 82-87.

140 Neste sentido, ressalva Judith Martins-Costa que: "Conquanto o princípio da boa-fé objetiva tenha chegado tarde ao ambiente juscultural brasileiro, o certo é que, ao menos desde a década de 1990, vem sendo sedimentado numa prática jurisprudencial expansiva. Assim ocorre em julgados referentes às relações civis de 'direito comum', mais abundantemente de direito do consumidor (em que adquire contornos próprios ligados à presunção de vulnerabilidade do consumidor no mercado
} 
Com o advento da Constituição de 1988 e a mudança de um paradigma centrado na proteção do patrimônio, essencialmente, para outro em que se privilegia a tutela da pessoa humana, sua existência, dignidade e o pleno desenvolvimento de sua personalidade, operou-se vultosa reforma em nosso ordenamento jurídico, através da inserção de uma base axiológica humanista e destacadamente solidária, pela qual as ações humanas devem pautar-se por um ideal de honradez, eticidade e probidade, como contraponto ao exagerado individualismo de antanho.

Como corolário dessa nova ordem de valores insculpida pela Constituição Federal de 1988, os efeitos sociais da conduta humana recebem a primazia do legislador, bem como do julgador, em detrimento da busca pela real intenção do sujeito ou da proteção de sua vontade interior. ${ }^{141}$

Por essa razão, importa o estabelecimento de um padrão ético de conduta, capaz de servir de parâmetro e de alicerce às relações intersubjetivas, em geral, e, em especial, às relações jurídicas, a fim de se distanciar da inglória busca acerca da real intenção da pessoa, aproximando-se, por conseguinte, do elemento ético essencial ao seu comportamento, trazendo-se para a ordem jurídica "um elemento de Direito Natural, que passa a integrar a norma de direito". ${ }^{142}$

Em um mundo pautado pela ótica do consumo, em que a apreensão de bens materiais e a apropriação de riquezas parece se sobrepor ao solidarismo social, o extremado individualismo acaba por sobrepujar a ética, a igualdade e a dignidade, sem

de consumo), e, também, nas relações de direito administrativo e de direito empresarial" (Os avatares do abuso de direito e o rumo indicado pela boa-fé objetiva, in: Gustavo Tepedino (Org.), Direito civil contemporâneo: novos problemas à luz da legalidade constitucional, São Paulo: Atlas, 2008, p. 80).

141 Como bem observa Teresa Negreiros, "ao direito, como regra, é irrelevante o que as pessoas sentem. Interessam, ao invés, o aspecto objetivo e exterior da conduta humana, e também os seus reflexos sociais" (O princípio da boa-fé contratual, in: Maria Celina Bodin de Moraes (Org.), Princípios do direito civil contemporâneo, Rio de Janeiro: Renovar, 2006, p. 222).

142 Álvaro Villaça Azevedo, O novo Código Civil Brasileiro: tramitação; função social do contrato; boafé objetiva; teoria da imprevisão e, em especial, onerosidade excessiva (laesio enormis), in: Arruda Alvim; Joaquim Pontes de Cerqueira César; Roberto Rosas (Coord.), Aspectos controvertidos do novo Código Civil: escritos em homenagem ao Ministro José Carlos Moreira Alves, São Paulo: RT, 2003, p. 34. 
pejo e sem limites, tudo para alcançar o ideal colimado, caracterizado pela busca incessante do "ter", em detrimento do "ser". ${ }^{143}$

Na verdade, a sociedade de hoje está baseada em uma indiferença extrema e no culto do particular, ${ }^{144}$ em que quase não existe espaço para o imperativo ético, o que acaba por tornar a conduta leal, honesta e correta, cada vez mais escassa, ressaltando-se a importância da consagração do princípio da boa-fé objetiva em nosso ordenamento, por tratar-se de um valor em extinção, tornando "imprescindível um aparato coercitivo capaz de induzir, pela ameaça de sanção, os desonestos, desleais e mentirosos a agirem como se não o fossem". ${ }^{145}$

Lamentavelmente, diversas ações humanas pautam-se exclusivamente pela tutela dos próprios interesses, envidando para que eles sejam alcançados a qualquer custo, mesmo que, para isso, tenham que ser ultrapassados os limites da solidariedade e do respeito aos direitos alheios.

Neste contexto, frequentes são as ofensas a direitos, consubstanciadas pelas mais diversas formas de ilícitos, sejam penais, sejam civis.

Ademais, poucas não são as ocasiões em que se extravasam os limites da ética, para a consecução do fim desejado, ainda que a conduta humana esteja amparada pelo suposto exercício regular de um direito reconhecido, caracterizando-se o exercício inadmissível de posições jurídicas - o denominado abuso de direito.

Em situações como estas, a boa-fé subjetiva mostra-se insuficiente por exigir a prova da ciência da antijuridicidade ou do potencial ofensivo das ações

143 Sobre o tema, Diogo Leite de Campos defende a rejeição da onipotência "da vontade do eu: tudo, agora, para sempre. Dinheiro, aplausos, corpos, poder... Tudo em quantidades desmesuradas, rejeitando (desconhecendo) as limitações, a dor, a morte que fazem parte essencial da condição humana. Cada um o maior, o que 'vale' mais, o ídolo, a estrela. Não dando nada, recebendo tudo, esgotando os que o cercam. Individualismo levado ao extremo em termos de predação, de ausência de limites, de negação de valores, de negação do tu, do vós e portanto do nós" (Nós. Estudos sobre os direitos da pessoa, Coimbra: Almedina, 2004, p. 11).

144 Pietro Barcellona, O egoísmo maduro e a insensatez do capital, cit., p. 17.

145 Teresa Negreiros, O princípio da boa-fé contratual, cit., p. 222. 
perpetradas pelo sujeito, eis que a conduta humana pode estar pautada pela ignorância do ilícito e, mesmo nessa hipótese, estar despida de lealdade e honradez, ferindo de morte os padrões éticos tão caros ao tráfego jurídico e ao convívio social. ${ }^{146}$

Nesse sentido, a boa-fé objetiva consiste, em sua essência, em dever geral de conduta ética, ressalvando-se, destarte, a correção e a lealdade daquele que praticou o ato jurídico, de modo que a ignorância de vício capaz de invalidá-lo ou até mesmo a intenção de prejudicar terceiro não afastam a necessidade de se perquirir sobre o comportamento adotado antes, durante e depois da celebração do contrato ou da prática de determinado ato. ${ }^{147}$

Trata-se, portanto, de princípio normativo cogente, eis que alicerçado no bem comum e nos princípios da solidariedade e da justiça social, expressos nos arts. 3. ${ }^{\circ}$, inciso I, e 170 da Constituição Federal de 1988, devendo prevalecer sobre as convenções, posto integrar a ordem jurídica brasileira como dever geral de conduta indissociável do ato ou do negócio jurídico. ${ }^{148}$

146 "Em diversos termos, alguém pode perfeitamente ignorar o indevido de sua conduta, portanto obrando de boa-fé (subjetiva) e, ainda assim, ostentar comportamento despido de boa-fé objetiva, que significa um padrão de conduta leal, pressuposto da tutela da legítima expectativa daquele com quem se contrata" (Cláudio Luiz Bueno de Godoy, Função social do contrato, 3. ed., São Paulo: Saraiva, 2009, p. 73).

147 Alípio Silveira define a boa-fé objetiva como o "comportamento inspirado no senso da probidade, quer no exercício leal e não caviloso dos direitos e das obrigações que dele derivam, quer no modo de fazê-los valer e de observá-los, respeitando em qualquer caso o escopo visado pelo ato jurídico, a harmonia dos interesses das partes e as exigências do bem comum" ( A boa-fé no Código Civil, São Paulo: Universitária de Direito, 1973, 2. ${ }^{\circ}$ vol., p. 8). António Manuel da Rocha e Menezes Cordeiro, por sua vez, adverte para a dificuldade de se conceituar o instituto: "Sendo uma criação do Direito, a boa-fé não opera como um conceito comum. Em vão se procuraria uma definição lapidar do instituto: evitadas, pela metodologia jurídica tentativas desse gênero seriam inaptas face ao alcance e riqueza reais da noção. A boa-fé traduz um estádio juscultural, manifesta uma Ciência do Direito e exprime um modo de decidir próprio de certa ordem sócio-jurídica" (Da boa-fé no direito civil, cit., p. 18).

148 "Haurida ou pelo menos difundida a partir da dicção do $§ 242$ do Código Civil alemão (BGB), segundo a qual 'o devedor está obrigado a executar a prestação como exige a boa-fé, com referência aos usos do tráfico', encerrando princípio implícito e inferido do solidarismo imposto pela Constituição Federal brasileira (arts. 3. ${ }^{\circ}$, I e 170, caput), muito embora levado ao texto positivo e expresso do Código de Defesa do Consumidor (art. 4. ${ }^{\circ}$, III), e mesmo do novo Código Civil, a boa-fé objetiva significa um standard, um padrão de comportamento reto, leal, veraz, de colaboração mesmo, que se espera dos contratantes" (Cláudio Luiz Bueno de Godoy, Função social do contrato, cit., p. 71-72). 
De fato, o princípio da boa-fé objetiva apresenta-se como expressão do princípio geral da solidariedade social, possuindo aplicação imediata e espraiando-se pelos diversos ramos do direito privado, como dever de cooperação e de lealdade recíprocas em qualquer tipo de relação jurídica. ${ }^{149}$

E foi em decorrência dessa ordem de valores trazidas a lume pela Constituição Federal de 1988 que se operou a expressa consagração do princípio da boa-fé objetiva em nosso direito positivado, o que se verifica pela letra dos arts. 4 . $^{\circ}$, inc. III, e 51, inc. IV, do Código de Defesa do Consumidor, bem como pelo disposto pelo Código Civil de 2002, em seus arts. 113, 187 e 422, ${ }^{150}$ cumprindo o legislador infraconstitucional com sua missão de estabelecer a eticidade e a solidariedade como princípios de nosso ordenamento, instilando nos particulares o dever de conduta probo e leal, a fim de preservar valores essenciais à convivência social. ${ }^{151}$

Neste contexto, deve-se ressaltar que, assim como a confiança, a boa-fé objetiva possui fundamental importância para a presente tese, eis que intimamente ligadas, posto a segunda conferir o amparo legal à primeira. ${ }^{152}$

149 "Embora a construção inicial da boa-fé objetiva - como um princípio geral de cooperação e lealdade recíproca entre as partes - tenha prescindido de fundamentações axiológicas precisas, não há, hoje, dúvida de que ela representa expressão da solidariedade social no campo das relações privadas" (Anderson Schreiber, A proibição de comportamento contraditório. Tutela da confiança e venire contra factum proprium, cit., p. 84).

150 "O princípio da boa-fé nos parece um destes instrumentos jurídicos capazes de conformar o direito civil à hierarquia de valores e de interesses prevista constitucionalmente. Trata-se, antes de mais nada, de reconhecer que o contrato - como, em geral, as relações obrigacionais - deve ser valorado em seus meios e fins segundo a ordem jurídico-econômica desenhada na Constituição" (Teresa Negreiros, Fundamentos para uma interpretação constitucional do princípio da boa-fé, cit., p. 269).

151 O princípio da boa-fé objetiva insere-se num processo de retomada da consciência ética no Direito Civil, sobretudo no direito das obrigações, libertando-se do cunho estritamente voluntarista e patrimonialista, objetivando a realização dos valores supremos inseridos no texto constitucional, com destaque para o valor relativo à dignidade da pessoa humana (Marília de Ávila e Silva Sampaio, Aplicação dos direitos fundamentais nas relações entre particulares e a boa-fé objetiva, Rio de Janeiro: Lumen Juris, 2006, p. 140.

152 'Nas suas manifestações subjectiva e objectiva, a boa-fé está ligada à confiança: a primeira dá, desta, o momento essencial; a segunda confere-lhe a base juspositiva necessária quando, para tanto, falte uma disposição legal específica. Ambas, por fim, carreiam as razões sistemáticas que se realizam na confiança e justificam, explicando, a sua dignidade jurídica e cuja projecção transcende o campo civil” (António Manuel da Rocha e Menezes Cordeiro. Da boa-fé no direito civil, cit., p. 1.250). 
Por conseguinte, tanto confiança como boa-fé conferem ao presente trabalho mecanismos indispensáveis para a apreciação da responsabilidade por informações, conselhos e recomendações nas relações entre particulares.

Assim, é cediço que a boa-fé e a confiança possuem inequívoca importância na fase pré-contratual em que as tratativas negociais pautam-se nas expectativas criadas pelas informações prestadas pelas partes, gerando ou não o dever de indenizar, em decorrência de sua frustração, e, até mesmo, a possibilidade de se manter as posições representadas como efetivas pelos contratantes.

O mesmo se diga pelas expectativas criadas por conselhos ou recomendações potencialmente lesivos aos sujeitos da relação privada, mas que, por outro lado, podem ter sido prestados sem nenhum potencial danoso, o que é característico de muitas situações do convívio social, em que as pessoas trocam experiências sem criarem um vínculo efetivo entre elas e sem gerar justas expectativas em seus interlocutores.

Por outro lado, a troca de informações também é essencial no momento da conclusão e execução do contrato, em que se evidenciam os deveres de cooperação e de informação, dentre outros, ensejando a colaboração mútua das partes, expressão dos princípios da função social, da boa-fé objetiva e da solidariedade social.

É nessa fase, em regra, que as expectativas dos contratantes se efetivam, impondo-se que a sua conduta seja transparente, evidenciando-se a sua lealdade e garantindo-se a celebração de acordos pautados pela ética e probidade, repugnando-se as condutas lesivas e a imposição de cláusulas abusivas.

Pretende-se que parte e contraparte não envidem esforços para que o objeto do contrato seja alcançado de maneira a propiciar a ambos a satisfação de suas pretensões, fazendo com que atuem conjuntamente e em sintonia para a consecução desse objetivo comum. 
Dessa forma, seria possível firmar um contrato sociável, destacadamente marcado pela lealdade entre as partes, que reprove condutas desleais e esteja alicerçado sobre o espírito cívico, além de solidário, apresentando como característica marcante a cooperação e a colaboração entre as partes, sinal de solidariedade e fraternidade nas avenças. $^{153}$

E a exigência de um padrão de conduta ético não se esvai com a extinção do contrato, mas estende-se para além de sua execução, eis que, até mesmo na fase póscontratual, exige-se que parte e contraparte ajam de forma proba e leal, em estreita consonância com o princípio da boa-fé objetiva.

Deste modo, verifica-se que a boa-fé objetiva impõe aos sujeitos de relações jurídicas um determinado padrão de conduta fundada no solidarismo social e na confiança. Outrossim, cabe ressaltar que a boa-fé objetiva possui uma tríplice função que merece ser analisada de maneira mais aprofundada a fim de se lograr alcançar o objeto da presente tese.

\subsubsection{A tríplice função da boa-fé objetiva}

Ao discorrer sobre a boa-fé objetiva, a doutrina tradicionalmente tem apontado uma tríplice função do instituto, ${ }^{154}$ consubstanciada na interpretação dos negócios jurídicos em geral de acordo com os seus ditames, pela criação dos denominados deveres anexos de conduta, assim como pela imposição de limites ao exercício dos direitos subjetivos.

Neste sentido, observa Judith Martins-Costa que à boa-fé objetiva são imputadas três funções distintas: a) a de cânone hermenêutico-integrativo do contrato;

153 Cláudio Luiz Bueno de Godoy, Função social do contrato, cit., p. 75.

154 Antonio Junqueira de Azevedo, Insuficiências, deficiências e desatualização do Projeto de Código Civil na questão da boa-fé objetiva nos contratos, $R T$, v. 775, p. 14, São Paulo: RT, maio de 2000. 
b) a de norma de criação de deveres jurídicos; e c) a de norma de limitação ao exercício dos direitos subjetivos. ${ }^{155}$

Antonio Junqueira de Azevedo e Francisco Paulo de Crescenzo Marino, em revisão à monumental obra de Orlando Gomes, apontam a existência de uma classificação tripartite das funções da boa-fé objetiva, que seriam a função interpretativa, a função supletiva e a função corretiva. ${ }^{156}$

Essa classificação será adotada em nosso trabalho, por julgarmos a mais adequada para o desenvolvimento do tema em questão.

\subsubsection{A função interpretativa da boa-fé}

Em sua função interpretativa busca-se apreender o alcance do consenso de ambas as partes, os objetivos comuns desejados no momento da entabulação do negócio. ${ }^{157}$

Em revisão à obra de Orlando Gomes, Antonio Junqueira de Azevedo e Francisco Paulo de Crescenzo Marino observam que a função interpretativa da boa-fé encontra-se disposta pelo art. $113^{158}$ do Código Civil e consiste em uma segunda fase da interpretação contratual que tem por objeto eliminar as falhas da declaração negocial. Assim, interpretar de acordo com a boa-fé significa substituir o ponto de vista relevante, para posicionar no contexto do contrato um modelo de pessoa normal, razoável,

55 Judith Martins-Costa, A boa-fé no direito privado, São Paulo: RT, 1999, p. 427-428.

156 Orlando Gomes, Contratos, 26. ed. atual. por Antonio Junqueira de Azevedo e Francisco de Paulo de Crescenzo Marino, Rio de Janeiro: Forense, 2007, p. 44.

157 Como bem assevera Cláudio Luiz Bueno de Godoy, “o intérprete pode valer-se de elementos do próprio contrato (lugar de entabulação, qualificação das partes, dentre outros dados) ou de elementos chamados extracontratuais, de que é exemplo o comportamento das partes, no direito italiano previsto no art. 11.362 do Código Civil como comportamento complessivo delle parti, a que, no direito pátrio corresponde à assim denominada interpretação autêntica, inclusive disposta no art. 131, n. 3, do antigo Código Comercial, haurida a conduta ostentada pelas partes em relação ao objeto do ajuste" (Função social do contrato, cit., p. 76).

158 “Art. 113. Os negócios jurídicos devem ser interpretados conforme a boa-fé e os usos do lugar de sua celebração." 
averiguando-se "o sentido que essa pessoa atribuiria à declaração negocial caso houvesse percebido a deficiência". ${ }^{159}$

Para Clóvis do Couto e Silva não se deve negar a existência de uma relação entre a hermenêutica integradora e o princípio da boa-fé, consubstanciada por um processo hermenêutico em que se cuida de conferir justa medida à vontade objeto da interpretação, evitando-se o psicologismo e o subjetivismo. Ademais, o princípio da boa-fé delineia o campo a ser preenchido pela interpretação integradora, pois, ao se perquirir acerca dos propósitos e intenções das partes contratantes, é possível que se verifique a contrariedade do ato à boa-fé e aos bons costumes. ${ }^{160}$

Por sua vez, Ricardo Luis Lorenzetti assinala que a boa-fé objetiva é regra de interpretação, ajudando a decifrar o sentido daquilo que foi acordado. Trata-se de regra hermenêutica objetiva, posto que o standard não se refere ao que as partes efetivamente entenderam, mas ao que poderiam entender conforme seria ordinário que entendessem. Esse standard objetivo pelo qual as partes puderam entender deve ser construído tomando por base os costumes negociais existentes no momento de contratar e na seara negocial que o contrato se desenvolve. Esses costumes são os bons costumes, já que o juiz está autorizado a prescindir dos maus costumes como regra hermenêutica. $^{161}$

Deste modo, é possível verificar a importância da boa-fé objetiva como elemento de integração, estabelecendo um padrão de interpretação que não quer significar a busca pela verdadeira compreensão das partes no momento da efetivação do negócio - o estado mental subjetivo do agente -, mas sim perquirir por um

159 Orlando Gomes, Contratos, cit., p. 44.

160 Clóvis do Couto e Silva, A obrigação como processo, Reimpressão, Rio de Janeiro: FGV, 2007, p. 35-36.

161 No original: "La buena fe es regla de interpretación, y, por lo tanto, ayuda a desentrañar el sentido de lo acordado. Como regla hermenéutica es objetiva, puesto que el standard no se refiere a lo que las partes entendieron efectivamente, sino a lo que pudieron entender conforme a lo que es ordinario que entiendan. El standard objetivo referido a lo que las partes pudieron entender se debe construir en base a las costumbres negociales existentes al momento de contratar en el sector de negocios en que el contrato se desenvuelve. Estas costumbres son las buenas costumbres, ya que el juez está autorizado a prescindir de las 'malas costumbres' como regla hermenéutica" (Ricardo Luis Lorenzetti, Tratado de los contratos: parte general, cit., p. 149). 
comportamento ético e pela representação que uma pessoa leal e proba tivesse por efetiva.

Em suma, busca-se uma valoração do comportamento das partes a partir de um padrão ético de conduta, essencial para o desenvolvimento da vida em sociedade, fundamentado na base axiológica de nosso ordenamento, mas também em normas sociais e nos bons costumes. ${ }^{162}$

Assim, o sistema jurídico dimana diretivas axiológicas que são concretizadas pela boa-fé, funcionando como parâmetros fundamentais para a interpretação do negócio jurídico. Isso significa dizer que devem ser preservadas as expectativas que as partes tenham por efetivas, bem como a confiança depositada no momento da efetivação do negócio. ${ }^{163}$

Esse modelo de interpretação que finca seus alicerces na boa-fé objetiva apresenta especial relevância para o presente trabalho, posto distanciar-se da intenção do indivíduo para aproximar-se do elemento ético essencial à sua conduta, o que será de fundamental importância para se proceder à análise da extensão da responsabilidade decorrente da informação, do conselho e da recomendação nas relações entre particulares, consoante restará demonstrado nos capítulos posteriores.

\subsubsection{A função supletiva da boa-fé}

A função supletiva da boa-fé objetiva cria os chamados deveres jurídicos anexos - que também podem ser denominados de secundários ou instrumentais ${ }^{164}-\mathrm{e}$

162 "A aplicação da boa-fé refere-se aos valores subjacentes ao ordenamento, mas também externos a ele." No original: "L'applicazione della buona fede fa riferimento dunque ai valori sottostanti l'ordinamento ma anche esterni ad esso" (Guido Alpa, Corso di diritto contrattuale, cit., p. 102).

163 "O contrato deve ser interpretado de forma a preservar a confiança, a justa expectativa dos contratantes. Destarte, as cláusulas contratuais devem ser entendidas de acordo com seu sentido objetivo e aparente, interpretando-se-as sempre em função de um significado que o standard de conduta leal aponte ser o mais razoável. Ou seja, as declarações de vontade, no contrato, devem ser interpretadas de acordo com o que seria o razoavelmente esperado de um contratante leal" (Cláudio Luiz Bueno de Godoy, Função social do contrato, cit., p. 77).

164 Clóvis do Couto e Silva, A obrigação como processo, cit., p. 35-36. 
está positivada pela redação do art. 422 do Código Civil, ao estabelecer que "os contratantes são obrigados a guardar, assim na conclusão do contrato, como em sua execução, os princípios de probidade e boa-fé".

Não obstante a redação do mencionado dispositivo legal, é fato que o padrão de conduta que dimana da boa-fé objetiva, assim como os deveres anexos que dela decorrem, não se limita à conclusão e execução do contrato, mas estende-se para o período posterior ao fim da relação contratual e também se impõe na fase das tratativas negociais que antecede a celebração da avença.

Com efeito, a adoção de um padrão ético de conduta constitui diretriz de nosso ordenamento para todas as relações intersubjetivas e não só aquelas que estejam amparadas por um contrato já celebrado. Por conseguinte, na fase das negociações preliminares impõe-se aos negociantes que ajam de acordo com os ditames da boa-fé e dos bons costumes, assim como se exige uma conduta leal e honesta daqueles que foram parte em um negócio jurídico já extinto, o que demonstra a timidez e imprecisão da redação do art. 422 do Código Civil. ${ }^{165}$

É notório que no período que antecede a celebração do contrato existem questões potencialmente causadoras de danos, como aquela decorrente da retirada abrupta e imotivada das negociações preliminares, impondo-se deveres éticos de conduta aos negociantes, ainda que o contrato não chegue a ser celebrado, para que se atinja o ideal colimado por uma ordem jurídica fundada na confiança e na boa-fé.

165 Álvaro Villaça de Azevedo ressalta o fato de nosso Código Civil não haver cuidado convenientemente da boa-fé objetiva, pois, "além das tratativas iniciais (contratações preliminares de viabilidade negocial, minutas etc.), da conclusão do contrato (formação) e de sua execução, em que ela deve estar presente, deve, também, ser observada após sua extinção, em que há segredos das partes contratantes, por exemplo, que se conhecidos durante a contratação, devem ser preservados e não difundidos; além de outros valores éticos" (O novo Código Civil brasileiro: tramitação; função social do contrato; boa-fé objetiva; teoria da imprevisão e, em especial, onerosidade excessiva (laesio enormis), cit., p. 35). Neste mesmo sentido é a ressalva de Cláudio Luiz Bueno de Godoy: "Importante notar, porém, que esses deveres anexos - de resto como a boa-fé em si -, quaisquer que sejam suas classificações, sempre de índole meramente exemplificativa, nascem antes e perduram até depois do contrato. Em diversos momentos, a boa-fé objetiva impõe deveres que antecedem a obrigação e persistem até depois dela, revelando-a um verdadeiro processo que não mais se limita apenas à visualização da prestação ou prestações assim ditas principais, constatação, aliás, que faltou na redação do art. 422 do novo Código Civil, inclusive já objeto de proposta de alteração" (Função social do contrato, cit., p. 81). 
O mesmo se diga da conduta das partes contratantes em um momento posterior à conclusão e execução do contrato, eis que o dever de lealdade e segurança não cessa com a extinção do contrato, mas se projeta para o período posterior ao fim da avença, como corolário da base valorativa de nosso ordenamento e do princípio da boafé objetiva.

Deste modo, é possível verificar que os deveres anexos se protraem para a fase posterior à execução do contrato no que se convencionou chamar de eficácia post factum finitum.

Neste sentido, salienta Rogerio Ferraz Donnini que os deveres anexos continuam a existir para os contraentes ainda que a prestação contratual tenha se efetivado, com a consequente extinção do contrato, em virtude de esses deveres serem inerentes à avença, estando vinculados ao acordado, mesmo após seu término decorrente do adimplemento das obrigações ali assumidas. ${ }^{166}$

Sobre o tema, Menezes Cordeiro assinala que, uma vez extinta a obrigação, podem subsistir, a cargo das antigas partes, os deveres de lealdade de proteção e de informação, o que significa que as partes ficam vinculadas a não adotar atitudes que possam frustrar o objetivo perseguido pelo contrato ou possam implicar diminuição das vantagens decorrentes do acordo celebrado, além de significar que os contratantes permanecem vinculados a não provocarem danos mútuos e de prestarem informações que sejam relevantes para o ato antes efetivado. ${ }^{167}$

$\mathrm{Na}$ verdade, consoante restará demonstrado no capítulo terceiro de nossa tese, entendemos que esse dever de conduta ético, leal e de colaboração não se limita apenas às relações negociais, mas estende-se por todo o nosso ordenamento, em decorrência da base valorativa de nosso sistema.

\footnotetext{
166 Rogério Ferraz Donnini, Responsabilidade civil pós-contratual, 2. ed., São Paulo: Saraiva, 2007, p. 157.

167 António Manuel da Rocha e Menezes Cordeiro, Da boa-fé no direito civil, cit., p. 628-629.
} 
Dessa forma, a ordem jurídica nacional impõe a todos um parâmetro de comportamento assentado na confiança, na boa-fé e no respeito à dignidade humana e ao solidarismo social, o que resulta no surgimento de deveres de conduta, dentre os quais aqueles que ora são objeto de nossa análise.

Entretanto, por se estar procedendo à análise dos chamados deveres anexos ao contrato, nossa investigação, neste tópico, limitar-se-á à relação contratual, entendendo-se como tal todo o processo obrigacional que a envolve, de acordo com a ampla concepção elaborada por Clóvis do Couto e Silva, ${ }^{168}$ o que abrange, além da fase contratual propriamente dita, aquela que se refere às tratativas negociais (précontratual), assim como a que se estende para um momento posterior a sua extinção (pós-contratual).

Neste contexto, ao discorrer sobre o tema, Caio Mário da Silva Pereira observa que o princípio da boa-fé objetiva possui o condão de criar deveres jurídicos anexos, como, por exemplo, os "deveres de correção, cuidado, cooperação, sigilo, prestação de contas". ${ }^{169}$

Karl Larenz salientava a existência de deveres de conduta que se referem à preparação da prestação propriamente dita, à forma de sua execução, à cooperação eventualmente necessária de ambas as partes e à consideração que segundo a equidade cada parte pode esperar da outra em relação semelhante. ${ }^{170}$

Sobre o que denomina de deveres acessórios, Menezes Cordeiro verifica a possibilidade de uma tripartição entre deveres de proteção, de esclarecimento e lealdade. Por deveres de proteção devem ser entendidos aqueles que se encontram

168 Clóvis do Couto e Silva, A obrigação como processo, cit.

169 Caio Mário da Silva Pereira, Instituições de direito civil. Introdução ao direito civil: teoria geral do direito civil, 23. ed., rev. e atual. por Maria Celina Bodin de Moraes, Rio de Janeiro: Forense, 2009, v. 1, p. 431.

170 No original: "De las exigencias de la buena fe derivan para todos los participantes en una relación obligatoria determinados deberes de conducta que hacen referencia a la preparación de la prestación propiamente dicha, a la forma de su ejecución, a la consideración que según la equidad puede cada parte esperar de la otra en semejante relación" (Karl Larenz, Derecho de obligaciones, cit., t. I, p. 151. 
ligados a evitar que sejam infligidos danos mútuos nas partes contratantes ou em seu patrimônio, enquanto perdure o fenômeno contratual. Já os deveres de esclarecimento obrigam as partes a informarem-se mutuamente acerca de todos os aspectos atinentes ao vínculo contratual, desde as ocorrências que possuam relação com a avença, até os efeitos que possam advir de sua execução. Os deveres de lealdade, por sua vez, impõem aos sujeitos da relação contratual que se abstenham de condutas que possam falsear o objetivo do negócio ou desequilibrar as prestações consignadas pelas partes. ${ }^{171}$

Não obstante a classificação que se pretenda adotar, todas elas de cunho exemplificativo, é possível verificar que esses deveres decorrentes da boa-fé objetiva presumem uma conduta idônea, impondo um comportamento leal e a cooperação das partes para que os fins colimados pela relação contratual sejam atingidos, tutelando-se de forma equânime os recíprocos interesses dos contratantes.

Portanto, inúmeros são os deveres que podem decorrer desse padrão de conduta, tais como os deveres de informação e esclarecimento, essencial para a presente tese, de cooperação e de colaboração, de proteção, de segurança, de sigilo etc.

Para Judith Martins-Costa, entre esses deveres encontram-se, por exemplo: a) os deveres de cuidado, previdência e segurança, como é o caso daquele imposto ao depositário, de bem acondicionar o objeto depositado e não somente guardá-lo; b) os deveres de aviso e esclarecimento, como o do advogado que deve aconselhar o seu cliente sobre o que é melhor para o seu caso; c) os deveres de informação, que possuem importância exponencial nas relações de consumo; d) o dever de prestar contas, que incumbe a mandatários e gestores; e) os deveres de colaboração e de cooperação, como o de colaborar para o perfeito adimplemento da prestação principal; f) os deveres de proteção e cuidado com a pessoa e o patrimônio da contraparte; e g) os deveres de omissão e de segredo, tal como o dever de guardar sigilo sobre fatos ou atos dos quais se teve conhecimento em razão do contrato ou das tratativas. ${ }^{172}$

\footnotetext{
171 António Manuel da Rocha e Menezes Cordeiro, Da boa-fé no direito civil, cit., p. 603-607.

172 Judith Martins-Costa, A boa-fé no direito privado, cit., p. 439.
} 
Karina Nunes Fritz, por sua vez, também faz detalhado elenco do que julga serem os principais desses deveres, que, em sua opinião, devem ser denominados deveres de consideração: a) deveres de executar a prestação com lealdade, que significa a execução da prestação de acordo com o espírito da relação obrigacional, levando em consideração os legítimos interesses do parceiro contratual e não só o sentido literal do texto contratual; b) deveres de consideração, implicando o dever das partes de agirem ponderando e respeitando os interesses do outro em todo o processo obrigacional; c) deveres de colaboração, a exigir que as partes colaborem vivamente para o alcance do êxito contratual, omitindo-se de quaisquer ações capazes de pôr em perigo ou frustrar o fim essencial da relação contratual; d) deveres de atuação conjunta, em que se exige uma atuação concorrente das partes para que a finalidade da relação obrigacional possa ser alcançada satisfatoriamente; e) deveres de informação $e$ esclarecimento, em que cada uma das partes deve informar e esclarecer a outra acerca do negócio jurídico, bem como sobre o que tange à existência e extensão de suas obrigações e o que for necessário para a execução e satisfação do fim do contrato; f) deveres de proteção, pelos quais se protegem os bens jurídicos da contraparte que podem eventualmente ser atingidos durante a execução da prestação; g) deveres de guarda e manutenção, que recaem sobre o objeto do contrato e perduram da conclusão até a tradição, incluindo-se o embalo e envio ao credor; e h) deveres de sigilo, que recaem, de modo geral, sobre todas as informações potencialmente lesivas para as partes. $^{173}$

Respeitadas todas as formas de classificação elencadas e sem pretender desmerecer qualquer uma delas, concordamos com a opinião de Menezes Cordeiro no sentido de poder classificar os deveres anexos de forma tripartite: a) deveres de proteção, b) deveres de lealdade e c) deveres de esclarecimento e informação. ${ }^{174}$

\footnotetext{
173 Karina Nunes Fritz, Boa-fé objetiva na fase pré-contratual. A responsabilidade pré-contratual por ruptura das negociações, Curitiba: Juruá, 2009, p. 207-212.

174 Neste mesmo sentido, confira-se a lição de Jorge Cesa Ferreira da Silva, que também parte dos ensinamentos de Menezes Cordeiro para chegar a três grandes grupos de deveres: "os deveres de proteção, os de lealdade e cooperação e os de esclarecimento e informação" ( $A$ boa-fé e a violação positiva do contrato, Rio de Janeiro: Renovar, 2002, p. 108-119).
} 
Por deveres de proteção devem ser entendidos aqueles que visam à proteção da pessoa e do patrimônio das partes em todo o processo obrigacional, iniciando-se pela fase das tratativas negociais, passando-se pela conclusão e execução do contrato e indo até o momento posterior à extinção do pacto. Compreendem-se neste grupo de deveres, por exemplo, o dever de cuidado, de previdência e de segurança citados por Judith Martins-Costa, assim como os deveres de guarda e de manutenção elencados por Karina Nunes Fritz.

Já os deveres de lealdade impõem às partes que procedam durante todo o fenômeno contratual com vistas a alcançar os objetivos pretendidos pela relação contratual, em constante cooperação e consideração, abstendo-se de praticar atos que possam acarretar a frustração do fim do contrato ou a quebra de seu equilíbrio. Sob o pálio dos deveres de lealdade encontram-se, exemplificativamente, os deveres de cooperação, colaboração e atuação conjunta, todos eles a ensejar o mútuo comprometimento de parte e contraparte para a consecução do fim almejado pelo contrato.

Por deveres de esclarecimento e de informação compreendem-se aqueles que obrigam as partes a prestarem todas as informações necessárias para atingir o fim contratual almejado, de forma recíproca, desde o momento em que se iniciam as negociações até depois da extinção do contrato. Neles estão compreendidos os deveres de prestação de contas, de aviso e de sigilo.

Todavia, deve-se ressaltar que os deveres anexos não constituem compartimentos estanques, sem qualquer comunicação, eis que relacionam de forma bastante dinâmica, pois aquele que, por exemplo, deixa de prestar à contraparte uma informação essencial para a celebração do contrato está faltando com o dever de esclarecimento e de informação, mas também não age de forma leal, em afronta ao dever de lealdade, e, dependendo da informação sonegada, pode estar violando também o dever de proteção.

Como se vê, a boa-fé objetiva não cria apenas deveres negativos - como é o caso da boa-fé subjetiva ao impor apenas um dever de não prejudicar -, mas também 
deveres positivos, exigindo-se que as partes envidem todos os seus esforços para que o objeto do contrato seja atingido em sua plenitude, fazendo com que todos consigam obter o proveito almejado quando de sua celebração e impondo-se que mantenham uma atitude leal e proba, mesmo após a sua extinção.

Como consequência, ao impor deveres positivos alarga-se a amplitude da boa-fé objetiva, permitindo-se, inclusive, a recepção pelo sistema de um direito a indenização por danos decorrentes da violação positiva dos contratos, que decorre do descumprimento dos deveres acessórios de conduta. ${ }^{175}$

Como bem define Jorge Cesa Ferreira da Silva, a violação positiva do contrato no Brasil pode ser entendida como todo inadimplemento que decorre do descumprimento culposo de algum dever anexo, quando este dever não tiver vinculação direta com os interesses do credor na prestação. ${ }^{176}$

Destarte, é possível verificar mais um ponto a ressaltar a inegável importância da função supletiva da boa-fé como criadora de deveres anexos de conduta.

Importa, portanto, a conduta ética e leal daquele que praticou o ato jurídico, de modo que a ignorância de eventual vício capaz de invalidar o contrato ou a intenção de prejudicar terceiro não afasta a necessidade de perquirir sobre o comportamento adotado antes, durante e depois da celebração do contrato ou da prática do ato jurídico.

\subsubsection{A função corretiva da boa-fé}

Em sua função corretiva a boa-fé objetiva atua essencialmente no controle das cláusulas abusivas e principalmente como limitação ao exercício inadmissível de posições jurídicas.

\footnotetext{
175 "Num prisma dogmático atual, a violação positiva do contrato, sendo de modo predominante, um conceito descritivo a obter pela negativa, compreende um âmbito não coincidente com os deveres acessórios" (António Manuel da Rocha e Menezes Cordeiro, Da boa-fé no direito civil, cit., p. 602).

176 Jorge Cesa Ferreira da Silva, A boa-fé e a violação positiva do contrato, cit., p. 273.
} 
Consoante ensina Claudio Luiz Bueno de Godoy, cláusula abusiva é aquela que está marcada pela unilateralidade, constituindo resultado de uma posição de força e de superioridade de uma das partes, impondo um desequilíbrio contratual de riscos e vantagens que a ordem jurídica impede ou corrige. ${ }^{177}$

Dessa forma, a unilateralidade dos direitos expressos em referida cláusula, aliada à falta de reciprocidade, acaba por caracterizar o desequilíbrio contratual, em favor daquele que impôs as condições contratuais e em detrimento do que foi compelido a aceitá-las.

Deste modo, a imposição de referidas cláusulas por uma das partes contratantes, além de ferir o equilíbrio do contrato, vai de encontro aos ditames da boafé objetiva, tornando imperiosa a sua função corretiva, a fim de sanar os danosos efeitos que delas decorram.

Além da função de coibir a imposição de cláusulas abusivas em uma relação contratual, outro vetor extremamente relevante da função corretiva da boa-fé objetiva consiste na limitação ao exercício inadmissível de posições jurídicas, consolidada pela redação do art. $187^{178}$ do Código Civil de 2002, enquanto critério de determinação do abuso de direito, tema que apresenta especial relevância para esta tese e merece um estudo mais aprofundado.

\subsubsection{Do abuso de direito}

Para o eficiente desenvolvimento de nosso trabalho faz-se imperioso analisar as questões relativas ao abuso de direito, eis que, em diversas ocasiões, a troca de informações entre sujeitos representa o exercício da autonomia privada, tão essencial às relações particulares.

177 Cláudio Luiz Bueno de Godoy, Função social do contrato, cit., p. 49.

178 “Art. 187. Também comete ato ilícito o titular de um direito que, ao exercê-lo, excede manifestamente os limites impostos pelo seu fim econômico ou social, pela boa-fé ou pelos bons costumes." 
Nestes casos, ao prestar uma informação, aconselhar ou recomendar a prática de um ato, as pessoas estão realizando ações características do convívio em sociedade, as quais, em regra, não geram danos aos seus destinatários e apenas representam o exercício do direito à liberdade de opinião, expressão e pensamento.

Entretanto, pode ocorrer que o responsável por uma informação, conselho ou recomendação exceda manifestamente os limites impostos pela boa-fé e pelos bons costumes, agindo de forma desleal e desonesta e causando danos a outrem, o que consubstancia o exercício abusivo do direito, caracterizado pela afronta aos limites impostos pela boa-fé e pelos bons costumes, assim como àqueles fixados pela finalidade social ou econômica dos direitos. ${ }^{179}$

A expressão "abuso de direito" foi cunhada pelo belga Laurent e, consoante assinala Menezes Cordeiro, foi criada para denominar uma série de situações jurídicas ocorridas na França, em que o tribunal, muito embora tenha reconhecido o seu direito, acabou por condenar o réu em virtude das irregularidades cometidas no seu exercício. ${ }^{180}$

Não se trata de expressão livre de críticas, fundadas, especialmente, na ideia de que o exercício de um direito deve ser conforme ao Direito, caso contrário transformar-se-ia em um ilícito, o que evidenciaria a aparente contradição dessa denominação. ${ }^{181}$

179 "O fulcro principal na caracterização do abuso do direito é o respeito aos direitos alheios e aos valores basilares do sistema, como a boa-fé e os bons costumes, que trazem a presença da Ética, assim com a finalidade e função social e econômica no exercício dos direitos e que têm como fundamento último a solidariedade constitucional" (Teresa Ancona Lopez, Exercício abusivo do direito e suas limitações, cit., p. 540).

180 António Manuel da Rocha e Menezes Cordeiro, Da boa-fé objetiva no direito civil, cit., p. 661 e ss.

181 Neste sentido confira-se a crítica de Planiol à teoria do abuso do direito: "Esta nova doutrina assenta inteiramente numa linguagem insuficientemente estudada; a sua fórmula, uso abusivo dos direitos, é uma logomaquia porque, se eu exerço o próprio direito, o meu ato é lícito, e quando é ilícito é porque excedo o meu direito e atuo sem direito. É preciso não nos deixarmos enganar pelas palavras; o direito cessa onde o abuso começa, e não pode haver uso abusivo dum direito, pela razão irrefutável que um só e mesmo ato não pode ser, ao mesmo tempo, conforme ao direito e contrário ao direito" (Marcel Planiol, Traité élémentaire de droit civil, 11. ed., França: F. Pinchon Successeur, 1902, t. II, p. 329, apud Georges Ripert, A regra moral nas obrigações civis, tradução de Osório de Oliveira, São Paulo: Livraria Acadêmica, 1937, p. 166). 
Contudo, é essa a expressão que ganhou larga dimensão no âmbito jurídico e melhor representa as limitações ao exercício abusivo e potencialmente lesivo dos direitos, razão pela qual será adotada em nosso trabalho.

Ao compreender o abuso de direito como o exercício inadmissível de relações jurídicas, Menezes Cordeiro ressalva que existem limites ao exercício dos direitos impostos pela boa-fé e pelos bons costumes. Além disso, os direitos possuem um fim social e econômico que também limita ou pode limitar o seu exercício. ${ }^{182}$

Mafalda Miranda Barbosa, por sua vez, ressalta que o abuso de direito "configura-se como uma contradição entre os dois pólos que entretecem o direito subjetivo", pois a sua estrutura formal, reconhecida pelo ordenamento jurídico, e o fundamento normativo integrante desse mesmo direito, e que lhe confere materialidade, devem estar em conformidade, caso contrário ocorrerá o anunciado abuso. ${ }^{183}$

Para José de Oliveira Ascensão é possível enunciar o princípio de que o exercício do direito encontra seu limite quando ficar caracterizada "uma grave desproporção entre o benefício recebido e o prejuízo imposto a outrem". ${ }^{184}$

Como se vê, ao reconhecer a categoria do abuso de direito, a ordem jurídica acaba por estatuir os limites para o exercício dos direitos subjetivos e da autonomia privada no tráfego jurídico, consubstanciados pela boa-fé, pelos bons costumes e pelos fins sociais e econômicos do ordenamento.

Decorrente da concretização da boa-fé objetiva, em sua função corretiva, o abuso de direito possui relação com os seculares mandamentos honeste agere e alterum non laedere. Por honeste agere pode-se entender o sentido de se exercer o direito honestamente, como seria exercido por uma pessoa de bem. Já por alterum non laedere

\footnotetext{
182 António Manuel da Rocha e Menezes Cordeiro, Da boa-fé objetiva no direito civil, cit., p. 670-671.

183 Mafalda Miranda Barbosa, Liberdade vs. responsabilidade. A precaução como fundamento da imputação delitual?, Coimbra: Almedina, 2006, p. 310.

184 José de Oliveira Ascensão, Direito civil: teoria geral. Relações e situações jurídicas, cit., v. 3, p. 288.
} 
verifica-se a máxima de que o direito não pode ser exercido de modo danoso, não se permitindo ao titular do direito causar danos a outrem quando de seu exercício. ${ }^{185}$

Os bons costumes caracterizam-se por um destacado fundamento ético e moral, referindo-se a critérios éticos supralegais, bem como para as coordenadas éticas regentes na ordem social, em referência extrassistemática, pela qual o Direito busca encontrar "fora dos quadros reguladores formais, critérios de decisão e de valor que o transcendem e nessa medida o dominam". ${ }^{186}$

Por outro lado, o direito possui relevante função social e econômica, que não pode estar dissociada de seu exercício e é fundamental para a realização da justiça distributiva.

Cabe ressaltar, contudo, que a função corretiva da boa-fé que se refere diretamente ao abuso de direito não se restringe à limitação aos direitos subjetivos nem, exclusivamente, ao campo dos atos ilícitos, disseminando-se por todo o ordenamento.

De fato, em nosso entendimento, a norma insculpida no art. 187 do Código Civil é aplicável em toda a ordem jurídica e não apenas aos atos ilícitos, posto consistir uma limitação ao exercício dos direitos.

Assim, podemos citar o exemplo do proprietário que exerce o seu direito de propriedade sem qualquer utilidade ou comodidade, mas apenas para praticar atos emulativos ${ }^{187}$ contra seu vizinho e desafeto.

Nesse sentido, ensina Teresa Ancona Lopez que a consideração dessa autonomia torna possível que o exercício abusivo do direito constitua cláusula geral

185 Pedro Paes de Vasconcelos, Teoria geral do direito civil, 4. ed., Coimbra: Almedina, 2007, p. 267.

186 Idem, ibidem, p. 269.

187 José de Oliveira Ascensão, com propriedade, distingue os atos emulativos daqueles que denomina chicaneiros: "É ilegítimo o exercício formal, quando na realidade não há interesse: temos os atos ditos chicaneiros. Por maioria de razão, é ilegítimo o exercício quando o fim for prejudicar outrem: temos os atos ditos emulativos. Porque se afasta da função para que o direito foi concedido, o ato emulativo consubstancia um exercício disfuncional e como tal ilegítimo" (Direito civil: teoria geral. Relações e situações jurídicas, cit., v. 3, p. 269). 
para todos os casos em que o exercício do direito não possa ser admitido pelo sistema jurídico, não apenas no que se refere aos direitos subjetivos, mas também às outras prerrogativas deles desvinculadas. ${ }^{188}$

Por essa razão afirmamos que, além da limitação a esses direitos, há limites para o exercício inadmissível de posições jurídicas, eis que inúmeras situações podem caracterizá-lo e não só aquelas que estejam sob o pálio do direito subjetivo. Assim não se deve ater à fórmula dos direitos subjetivos, pois o abuso de direito pode se caracterizar no exercício de uma mera faculdade ou liberdade. O que se visa é o controle do exercício de um direito que formalmente exista, na medida em que seja uma manifestação da liberdade pessoal, o que leva a considerar que o exercício de uma mera liberdade, não conformada com o direito subjetivo, possa ser considerado abusivo. ${ }^{189}$

Esse também é o entendimento de Jorge Manuel Coutinho de Abreu ao discorrer sobre o abuso de direito e afirmar que o vocábulo direito, neste caso, deve ser entendido em sentido mais amplo, envolvendo todas as prerrogativas jurídicas subjetivas, os poderes, as faculdades e as liberdades, pois a razão do sancionamento para o comportamento considerado abusivo vale tanto para os direitos como para as outras prerrogativas privadas. ${ }^{190}$

$\mathrm{Na}$ verdade, essa autonomia decorre da adstrição do abuso de direito à boafé objetiva e à confiança, assim como sua estreita vinculação à base valorativa de nosso ordenamento.

Por conseguinte, o exercício inadmissível de posições jurídicas caracterizase de acordo com critérios objetivos estabelecidos em razão da ordem de valores de nosso sistema, fundado na socialidade e na ética.

\footnotetext{
188 Teresa Ancona Lopez, Exercício abusivo do direito e suas limitações, cit., p. 540.

189 Mafalda Miranda Barbosa, Liberdade vs. responsabilidade. A precaução como fundamento da imputação delitual?, cit., p. 320-321.

190 Jorge Manuel Coutinho de Abreu, Do abuso de direito. Ensaio de um critério em direito civil e nas deliberações sociais, Coimbra: Almedina, 2006, p. 67-68.
} 
Dessa forma, para que se consubstancie o abuso de direito não é necessária a comprovação da intenção do agente em exceder manifestamente os limites impostos pela boa-fé, pelos bons costumes ou pelos fins sociais e econômicos de nosso ordenamento. Sequer se exige sua ciência acerca desses limites, posto que sua conduta deva estar pautada pela ética, lealdade e honestidade, constituindo-se o exercício inadmissível de uma posição jurídica na hipótese de afronta a esses valores, o que caracteriza a sua antijuridicidade. ${ }^{191}$

Por fim, há que se ressaltar que o tratamento do abuso de direito enseja uma série de regulações típicas de comportamentos abusivos, tais como a exceptio doli, o venire contra factum proprium, a supressio, a surrectio e o tuo quoque.

A exceptio doli constitui o mais antigo dos tipos de reação contra a má-fé, consoante ensina Pedro Paes de Vasconcelos, derivando do direito romano, das legis actiones e dos juditia bonae fidei, quando o demandado se defendia através de uma exceptio, em que invocava um comportamento fraudulento por parte do titular do direito. Possui como fonte o dever de honeste agere e corresponde à máxima fraus omnia corrumpit. ${ }^{192}$

Portanto, a exceptio doli consiste na prerrogativa de quem está sendo demandado de suscitar em sua defesa a ocorrência de dolo por parte daquele que é responsável pela demanda.

Contudo, deve-se ressaltar que, historicamente, o uso da exceptio doli tem se efetivado de maneira ampla e generalizada, o que fez com que merecesse um uso decrescente na jurisprudência e certo desinteresse doutrinário, posto caracterizar um tipo muito fluido e de compreensão escassa, que acabaram por dar lugar a outros tipos

191 "O abuso é objetivo e não subjetivo. O ato é ilegítimo desde que desconforme a padrões objetivos de comportamento, não se exigindo a consciência do agente de prosseguir um exercício contra o direito. Isso não significa que, havendo intenção contrária ao direito, esta não deva ser também relevante" (José de Oliveira Ascensão, Direito civil: teoria geral. Relações e situações jurídicas, cit., v. 3, p. 277).

192 Pedro Paes de Vasconcelos, Teoria geral do direito civil, cit., p. 272. 
mais compreensivos e menos extensos recepcionados pelo princípio da boa-fé objetiva. $^{193}$

No entanto, ainda pode ser útil se for compreendida em um sentido mais restrito. Cite-se como exemplo particularmente relacionado ao nosso tema a hipótese do empreiteiro que informa ao dono da obra que fez todos os reparos a ele prometidos, para depois escusar-se à reparação alegando o decurso do prazo de garantia dos defeitos decorrentes da obra. ${ }^{194}$

A proibição do comportamento contraditório, por sua vez, estriba-se no brocardo nemo potest venire contra factum proprium, compreendendo uma ideia de repressão contra a incoerência, quando a contradição a atos próprios possa violar expectativas despertadas em outrem e assim causar-lhes prejuízos. ${ }^{195}$

Tutela-se, pois, a confiança, enquanto valor fundamental da ordem jurídica, proscrevendo-se as condutas eticamente reprováveis, contrárias à boa-fé e aos bons costumes, para o fim de se evitar que alguém exerça determinada posição jurídica para, posteriormente, apresentar um comportamento contrário a essa posição, antes assumida. $^{196}$

Menezes Cordeiro ordena a casuística decorrente do venire contra factum proprium em três grupos. No primeiro, o titular do direito potestativo manifesta a intenção de não exercê-lo, mas exerce-o. Como exemplo, cita o caso em que um senhorio concedeu ao inquilino a possibilidade de permanecer no local arrendado até certa data, mas, antes de seu advento, rescindiu o contrato. Em um segundo grupo, o titular de um direito subjetivo indica que não vai exercê-lo, mas exerce-o, como

\footnotetext{
193 António Manuel da Rocha e Menezes Cordeiro, Da boa-fé objetiva no direito civil, cit., p. 741.

194 José de Oliveira Ascensão, Direito civil: teoria geral. Relações e situações jurídicas, cit., v. 3, p. 289.

195 Anderson Schreiber, A proibição de comportamento contraditório. Tutela da confiança e venire contra factum proprium, cit., 2007, p. 96.

196 "Duplicata. Nulidade. Venire contra factum proprium. Atento à vedação de venire contra factum proprium, não há como se acolher a nulidade, por falta de lastro, de duplicata endossada e posta em circulação sem aceite, enquanto a emitente e a sacada, não obstante serem pessoas jurídicas diversas, são administradas por um mesmo sócio cotista, responsável tanto pela emissão quanto pelo aceite. Precedente citado: REsp 296.064-RJ, DJ 29/3/2004" (STJ, REsp 957.769-PE, rel. Min. João Otávio de Noronha, 4. ${ }^{a}$ Turma, v.u., j. 16.09.2008).
} 
acontece no caso de um agente que obtém um mandato exclusivo, mas em sua assinatura declara que a exclusividade é mera formalidade não exigível, para, ao depois, exigir a respectiva indenização por sua violação. E no terceiro grupo, a pessoa age ao abrigo de uma permissão genérica de atuação e não de um direito subjetivo, potestativo ou comum, declarando que não tomará determinada atitude, para posteriormente assumi-la. $^{197}$

A supressio e a surrectio correspondem ao comportamento contraditório do titular do direito, que deixa de exercê-lo durante um longo período para começar a exercê-lo depois dessa prolongada abstenção. Como bem salienta Pedro Paes de Vasconcelos, a abstenção prolongada no exercício de um direito pode suscitar, em certas circunstâncias, uma expectativa legítima e razoável de que o seu titular não irá exercê-lo ou que tenha renunciado ao próprio direito, ao exercício de alguns poderes que o integram ou a certo modo de seu exercício. ${ }^{198}$

A supressio significaria o desaparecimento do direito que não foi exercido durante um prolongado período de abstenção, ao passo que a surrectio consistiria no surgimento de um novo direito, antes não existente, em decorrência do decurso do tempo. $^{199}$

197 António Manuel da Rocha e Menezes Cordeiro, Da boa-fé objetiva no direito civil, cit., p. 747-749.

198 Pedro Paes de Vasconcelos, Teoria geral do direito civil, cit., p. 274.

199 "Direito civil. Vizinhança. Condomínio comercial que admite utilização mista de suas unidades autônomas. Instalação de equipamento por condômino que causa ruído. Indenização devida. Dano moral fixado em quantum razoável. 1. O exercício de posições jurídicas encontra-se limitado pela boa-fé objetiva. Assim, o condômino não pode exercer suas pretensões de forma anormal ou exagerada com a finalidade de prejudicar seu vizinho. Mais especificamente não se pode impor ao vizinho uma convenção condominial que jamais foi observada na prática e que se encontra completamente desconexa da realidade vivenciada no condomínio. 2. A 'supressio', regra que se desdobra do princípio da boa-fé objetiva, reconhece a perda da eficácia de um direito quando este longamente não é exercido ou observado. 3. Não age no exercício regular de direito a sociedade empresária que se estabelece em edifício cuja destinação mista é aceita, de fato, pela coletividade dos condôminos e pelo próprio Condomínio, pretendendo justificar o excesso de ruído por si causado com a imposição de regra constante da convenção condominial, que impõe o uso exclusivamente comercial, mas que é letra morta desde sua origem. 4. A modificação do quantum fixado a título de compensação por danos morais só deve ser feita em recurso especial quando aquele seja irrisório ou exagerado. Recurso especial não conhecido" (STJ, REsp 1096639-DF, Min. Nancy Andrighi, 3. ${ }^{a}$ Turma, v.u., j. 09.12.2008, DJ 03.02.2009). 
A fórmula tu quoque, por seu turno, consiste em uma regra pela qual a pessoa que viole determinada norma jurídica não pode, sem abuso, exercer a situação jurídica que essa mesma norma lhe atribuiria. Como ensina Menezes Cordeiro, fere a sensibilidade ética e jurídica que uma pessoa desrespeite o comando de uma norma e depois venha a exigir de outrem o seu acatamento. ${ }^{200}$

Assim, um sujeito que viole determinada norma jurídica e, depois, afirme a violação da mesma norma pela contrapart, afronta a boa-fé, abusando do direito.

Na lição de José de Oliveira Ascensão o tu quoque serve para "paralisar os efeitos de uma violação (objetiva) da relação em detrimento da parte que, por violação anterior, alterou o equilíbrio substancial prosseguido". ${ }^{201}$

Por fim, cabe ressaltar que todas essas funções da boa-fé possuem importância fundamental para as conclusões a que se pretende chegar em nossa tese, consoante restará demonstrado nos capítulos seguintes.

200 António Manuel da Rocha e Menezes Cordeiro, Da boa-fé objetiva no direito civil, cit., p. 838.

201 José de Oliveira Ascensão, Direito civil: teoria geral. Relações e situações jurídicas, cit., v. 3, p. 290. 


\section{3}

\section{A CONFIANÇA COMO UM DOS VALORES FUNDANTES DA RESPONSABILIDADE CIVIL NO SISTEMA JURÍDICO BRASILEIRO. FUNDAMENTOS DE UMA RESPONSABILIDADE PELA CONFIANÇA}

No presente capítulo pretende-se discorrer sobre o valor fundamental da confiança como um dos alicerces da responsabilidade civil em nosso sistema, a fim de construir os fundamentos de uma responsabilidade pela confiança, o que será fundamental para a digressão acerca da responsabilidade por conselhos, informações e recomendações.

Entretanto, para apresentar a fundamentação da responsabilidade pela confiança, faz-se necessário discorrer a respeito da ordem de valores estabelecida pela norma constitucional e da forma como se irradia por nosso ordenamento, especialmente no que se refere às relações de direito privado, área de concentração de nossa tese.

A questão relacionada à eficácia dos direitos fundamentais no âmbito das relações privadas constitui o centro de intenso e controvertido debate, merecendo ser objeto de nosso estudo. Isso porque pretendemos que os fundamentos da responsabilidade pela confiança sejam apresentados em consonância com a ordem de nosso sistema jurídico e não de uma maneira perfunctória, representada por um genérico recurso à boa-fé objetiva e aos seus efeitos.

Para tanto, faz-se imperiosa a análise das características essenciais de nosso sistema, antes de promover a discussão sobre os fundamentos da responsabilidade pela confiança.

Assim, o presente capítulo inicia-se pela apresentação da ordem de valores trazida a lume pela Constituição de 1988, para posteriormente analisar a forma de sua irradiação em nosso ordenamento e as características de nosso sistema, construindo-se o instrumental necessário para a apresentação e defesa da responsabilidade pela confiança. 


\subsection{O direito civil e a Constituição Federal de 1988}

Com o advento da Constituição Federal de 1988, a cláusula geral de tutela e promoção da dignidade da pessoa humana deve ser tomada como valor máximo de nosso ordenamento jurídico. ${ }^{202}$ Assim, a sua defesa e promoção, bem como a consequente proteção aos direitos da personalidade, constitui a base axiológica de nosso ordenamento e deve pautar o universo das relações jurídicas, seja de direito público ou de direito privado. ${ }^{203}$

Dessa forma, cabe ao Estado promover a tutela da pessoa humana, visando à garantia de acesso a uma vida digna, propiciando sua real proteção, no sentido de tornar efetivas as condições que permitam o desenvolvimento das relações pessoais, através de uma convivência livre de preconceitos e de restrições legais, a fim de que se torne possível o fortalecimento dos vínculos de solidariedade, igualdade e cooperação.

Neste sentido, a dignidade da pessoa humana constitui um imperativo jurídico categórico quando impõe o dever de reconhecer a intangibilidade da vida humana. No entanto, ao prescrever o respeito à integridade física e psíquica, às condições mínimas de vida e aos pressupostos mínimos de liberdade e de igualdade, representa imperativos jurídicos relativos. ${ }^{204}$

Em ambos os casos, contudo, a dignidade humana aparece como fundamento de toda a ordem jurídica, consoante dispõe o art. $1^{\circ}{ }^{\circ}$, inc. III, da Constituição Federal, consagrando-se como valor supremo da República Federativa do

202 Antonio Junqueira de Azevedo ensina que o conceito de dignidade da pessoa humana, "além de normativo, é axiológico, porque a dignidade humana é valor - a dignidade é a expressão do valor da pessoa humana. Todo 'valor' é projeção de um bem para alguém; no caso, a pessoa humana é o bem e a dignidade, o seu valor, isto é, a sua projeção" (Caracterização jurídica da dignidade da pessoa humana. Estudos e pareceres de direito privado, São Paulo: Saraiva, 2004, p. 3).

"A escolha da dignidade da pessoa humana como fundamento da República, associada ao objetivo fundamental de erradicação da pobreza e da marginalização, e de redução das desigualdades sociais, juntamente com a previsão do $\S 2 .^{\circ}$ do art. 5. $^{\circ}$, no sentido da não exclusão de quaisquer direitos e garantias, mesmo que não expressos, desde que decorrentes dos princípios adotados pelo texto maior, configuram uma verdadeira cláusula geral de tutela e promoção da pessoa humana, tomada como valor máximo pelo nosso ordenamento" (Gustavo Tepedino, A tutela da personalidade no ordenamento civil-constitucional brasileiro, Temas de direito civil, Rio de Janeiro: Renovar, 1999, p. 48).

204 Antonio Junqueira de Azevedo, Caracterização jurídica da dignidade da pessoa humana, cit., p. 3. 
Brasil, garantindo ao ser humano a liberdade para moldar seu próprio caráter e para poder escolher a forma de convivência social que melhor corresponde às suas expectativas e anseios, bem como preservando a sua incolumidade física.

Na verdade, como bem ressalva Gomes Canotilho, a consolidação da ideia da "necessidade de garantir o homem no plano econômico, social e cultural, de forma a alcançar um fundamento existencial-material, humanamente digno, passou a fazer parte do patrimônio da humanidade ${ }^{205 "}$ e não só do ordenamento jurídico brasileiro.

Por conseguinte, torna-se necessária a intervenção estatal no âmbito das relações privadas, com vistas a garantir o bem-estar social, a dignidade humana e a efetivação dos direitos sociais, no que se convencionou chamar de Estado Social (welfarestate), cuja concepção é bastante diferente daquela característica do Estado Liberal, ${ }^{206}$ pois o desenvolvimento e a amplitude da tutela dos direitos fundamentais impõem "a harmonização entre direitos de liberdade e direitos econômicos, sociais e culturais". 207

Em consonância com o seu comprometimento com o Estado Social, a ordem constitucional reconhece, expressamente, a tutela dos direitos sociais, assim como garante a proteção dos direitos dos trabalhadores, além de garantir a proteção dos "direitos inatos ao homem, anteriores e limitativos da ação do Estado (teoria naturalista dos direitos fundamentais)". ${ }^{208}$

\footnotetext{
205 José Joaquim Gomes Canotilho, Direito constitucional e teoria da Constituição, cit., p. 361.

206 “À compreensão do Estado atual, que descobriu a historicidade de seu objeto (e de sua própria historicidade), a 'invasão do tempo', a qual deixa converter aquela em 'categoria da estrutura interna do Estado e direito', está proibido o recurso a semelhantes idéias de Estado como uma unidade situada do outro lado das forças históricas reais, determinada, substancial-imutável; isso tanto mais que o desenvolvimento industrial moderno e as alterações, que ele produziu, não mais admitem descuidar o problema da formação da unidade política e isolar o Estado de seu substrato sociológico" (Konrad Hesse, Elementos de direito constitucional da República Federal da Alemanha, tradução de Luís Afonso Beck, Porto Alegre: Sergio Antonio Fabris, 1998, p. 31).

207 Jorge Miranda, Manual de direito constitucional, t. IV: Direitos fundamentais, 3. ed., Coimbra: Coimbra Ed., 2000, p. 27.
}

208 Carlos Alberto Bittar, O direito civil na Constituição de 1988, 2. ed., São Paulo: RT, 1990, p. 27. 
Trata-se da proteção dos direitos da personalidade, consagrada pela norma constitucional em seu art. 5. ${ }^{\circ}$, incisos X, XXVII e XVIII, assegurando-se o direito à vida, à segurança, à intimidade, à vida privada, à imagem, à proteção dos direitos autorais, incluídas as participações individuais em obras coletivas e a reprodução da voz e da imagem.

Entretanto, os dispositivos constitucionais não se limitam, apenas, a regular a relação Estado-indivíduo, mas também se estendem às relações entre particulares, ${ }^{209}$ na denominada eficácia horizontal dos direitos fundamentais, que consiste na irradiação das normas ou valores constitucionais aos diversos ramos do direito e cujo principal aspecto "revela-se na vinculação das relações entre particulares a direitos fundamentais". 210

Deve-se ressalvar, contudo, que a intervenção do constituinte não significa "uma absorção do direito civil por parte do direito constitucional, daí resultando numa drástica e autoritária redução nos espaços de liberdade garantidos à sociedade civil". ${ }^{211}$ Não se pretende aqui defender a tese de que o direito civil foi suprimido pelo direito constitucional, propalando-se o fim da dicotomia entre o direito público e o direito privado.

Pelo contrário, o que se pretende é a interpretação das normas de direito privado a partir da Constituição Federal, explorando-se ao máximo a compatibilidade do texto constitucional com as normas infraconstitucionais. ${ }^{212}$

209 "Nesse sentido, embora consagre também os direitos fundamentais que a Constituição alemã e a grande maioria das constituições ocidentais consagram no âmbito dos chamados direitos de defesa ou das chamadas liberdades públicas, muitos dispositivos da Constituição brasileira já dão a entender que eles não têm efeitos apenas na relação indivíduo-Estado, mas também nas relações dos indivíduos entre si" (Virgílio Afonso da Silva, A constitucionalização do direito. Os direitos fundamentais nas relações entre particulares, São Paulo: Malheiros, 2005, p. 22).

210 Virgílio Afonso da Silva, ibidem, p. 18.

211 Gustavo Tepedino, Normas constitucionais e relações de direito civil na experiência brasileira, Temas de direito civil, Rio de Janeiro: Renovar, 2006, t. II, p. 41.

212 Segundo Pietro Perlingieri, faz-se necessário "reconstruir o Direito Civil não como uma redução ou um aumento de tutela das situações patrimoniais, mas como uma tutela quantitativamente diversa", posto que, assim, seria possível se evitar "comprimir o livre e digno desenvolvimento da pessoa mediante esquemas inadequados e superados; permitir-se-ia o funcionamento de um sistema 
De fato, no presente trabalho não se defende a ideia de uma Constituiçãototal capaz de, além de dirigir a atividade estatal como um todo, regular todas as relações entre particulares, nos seus mais distintos pormenores, suprimindo-se a autonomia do legislador infraconstitucional, do próprio Poder Judiciário e, em especial, a autonomia privada, para afirmar a supremacia do direito público sobre todos os demais ramos do direito. ${ }^{213}$

Sob esse prisma, que não nos parece o mais adequado, a abrangência da norma constitucional expandir-se-ia por todas as relações entre particulares, de forma absoluta, exigindo-se a necessária interpretação da Constituição para a análise de quaisquer fatos que porventura sejam trazidos ao exame dos operadores do direito, desde os mais comezinhos até os mais complexos, o que acarretaria o verdadeiro sepultamento da autonomia privada e a absorção do direito civil por parte do direito constitucional, com riscos ao próprio princípio democrático. ${ }^{214}$

Como já dito, não é esse o propósito do presente trabalho nem se intenta esvaziar a importância do estudo do direito privado, mas propõe-se que se proceda a uma leitura diferente daquela clássica e inquebrantável divisão entre direito constitucional e direito civil como compartimentos estanques e incomunicáveis, para defender a tese de que os valores constitucionais irradiam-se nas relações entre

econômico misto, privado e público, inclinado a produzir modernamente e a distribuir com mais justiça"” (Perfis do direito civil: introdução ao direito civil constitucional, cit., p. 34).

213 Nesse sentido, Virgílio Afonso da Silva lança a advertência sobre a ideia de uma constitucionalização desproporcional, baseada em uma concepção totalizante de Constituição, ao analisar os fundamentos da denominada Constituição-total, ressalvando que a simples ideia de constitucionalização do direito ou de produção de efeitos constitucionais nas relações entre particulares não significa a tendência a "absolutizar a constituição e mitigar a importância do direito infraconstitucional e da autonomia privada" (A constitucionalização do direito. Os direitos fundamentais nas relações entre particulares, cit., p. 125).

214 "Com efeito, quem defende que tudo ou quase tudo já está decidido pela Constituição, e que o legislador é um mero executor das medidas já impostas pelo constituinte, nega, por conseqüência, a autonomia política ao povo para, em cada momento da sua história, realizar as próprias escolhas. Neste sentido, o excesso de constitucionalização do direito assume um viés antidemocrático" (Daniel Sarmento, O Neoconstitucionalismo no Brasil, in: George Salomão Leite; Ingo Wolfgang Sarlet (Cood.), Direitos fundamentais e Estado constitucional, São Paulo: RT/Coimbra: Coimbra Ed., 2009, p. 46). Nesse mesmo sentido é o entendimento de Virgílio Afonso da Silva ao afirmar que "em uma ordem jurídica constitucionalizada, o princípio democrático tenderia, sem dúvida, a definhar se, não houvesse nenhuma força contrária que pudesse garantir algumas competências decisórias ao legislador no âmbito dos direitos fundamentais" (A constitucionalização do direito. Os direitos fundamentais nas relações entre particulares, cit., p. 152). 
particulares, sem, contudo, suprimir a autonomia da vontade, fundamental para o seu desenvolvimento.

Portanto, reclama-se por uma leitura das normas de direito privado em conformidade com a ordem constitucional e sua base axiológica, não através de uma Constituição-total, mas por uma Constituição-moldura, "em que nem tudo está predefinido, que não pretende ser o estatuto total da vida em sociedade ou o fundamento material de todo e qualquer ato estatal ou privado". Segundo essa concepção, as relações entre particulares podem se desenvolver com base na autonomia privada, sem uma ordem de valores totalizante, mas fundada em princípios, enquanto mandamentos de otimização capazes de alicerçar a ideia de direitos fundamentais. ${ }^{215}$

Assim, reconhece-se que a Constituição Federal é a lei fundamental, a base de nosso ordenamento jurídico e o alicerce de normas e princípios fundamentais extensivos ao direito privado - afastando-se da concepção individualista tradicional da época das codificações -, mas sem que se sacrifique a autonomia privada e a liberdade existencial da pessoa, que também constituem princípios fundamentais de nossa ordem jurídica.

Destarte, evidencia-se uma transformação qualitativa dos institutos de direito civil sob a égide de nossa Lei Maior, sem que com isso se pretenda, como bem ressalva Gustavo Tepedino, "subtrair da autonomia privada seus poderes, titularidades e responsabilidades, na construção de uma sociedade (que o constituinte quis) justa e solidária". 216

No âmbito da responsabilidade civil, isso significa dizer que, ao intérprete, cabe afastar-se do caminho fácil que leva à conclusão acerca da existência de um rol taxativo de direitos da personalidade e da limitação da responsabilidade à reparação do dano consubstanciado pelo dolo ou culpa, para, por outro lado, buscar a ampliação da tutela da pessoa humana, através da preservação do interesse da vítima, fundada nos

\footnotetext{
215 Virgílio Afonso da Silva, ibidem, p. 18.

216 Gustavo Tepedino, Normas constitucionais e relações de direito civil na experiência brasileira, cit., p. 42.
} 
ideais de solidariedade e de cooperação e bastante distante dos rígidos moldes formulados pelo legislador de antanho para a hipótese de reparação de danos. ${ }^{217}$

De fato, consoante já afirmado, a cláusula geral de tutela e promoção da dignidade da pessoa humana e a consequente proteção aos direitos da personalidade devem ser tomadas como valor máximo e como base axiológica de nosso ordenamento jurídico. ${ }^{218}$ A partir dessa base pretende-se buscar soluções para a aparente antinomia entre o exercício da liberdade de informação e de opinião e o respeito à dignidade da pessoa humana, bem como a necessária reparação dos danos sofridos em virtude da atuação de outrem.

Nesse sentido, cabe ressaltar que os princípios fundamentais estabelecidos pela Constituição e a sua inflexão sobre o direito privado constituem tema essencial para a compreensão de nosso sistema jurídico, bem como para a busca de soluções para quaisquer problemas que se apresentem ao operador do direito nos dias de hoje, posto ser imperiosa a análise acerca da garantia e proteção dos direitos fundamentais e do modo como se irradiam nas relações entre particulares sob pena de se combalir os alicerces da própria cidadania.

A análise desses princípios e da forma como se permeiam no direito privado é o que se pretende no presente capítulo, para se afirmar que a clivagem "público e privado" deve ser analisada sob um novo enfoque e através de uma ordem de valores distinta daquela em que se assentava o ideal liberal, mas sem que isso signifique a absorção do direito privado pelo direito público.

Por essa razão, deve-se ressalvar a importância do direito civil enquanto sistema regulador das relações entre particulares, hoje revigorado e destinado a exercer a tutela dos direitos "civis" em uma nova síntese entre as relações civis e aquelas

217 Nesse sentido, ensina Pietro Perlingieri, é necessário que "a questão moral, entendida como efetivo respeito à dignidade da vida de cada homem e, portanto, como superioridade deste valor em relação a qualquer razão política da organização da vida em comum, seja resposta ao centro do debate na doutrina e no Foro, como única indicação idônea a impedir a vitória de um direito sem justiça" (Perfis do direito civil: introdução ao direito civil constitucional, cit., p. 23).

218 Gustavo Tepedino, A tutela da personalidade no ordenamento civil-constitucional brasileiro, cit., p. 48. 
econômicas e políticas, ${ }^{219}$ a fim de que tudo não seja reduzido à eficácia da norma constitucional e à tutela da dignidade da pessoa humana.

Não nos parece correto afirmar que a norma constitucional seja capaz de regular todos os pormenores das relações de direito privado, da construção de uma usina hidrelétrica à compra de um palito de fósforo; da contratação de uma prestadora de serviços de limpeza à locação de uma casa na praia. ${ }^{220}$

Da mesma forma, também nos parece equivocado o estudo das relações entre particulares apenas com base na incidência dos princípios constitucionais, a fim de se evitar uma axiologia meramente formal e generalizante, que pode ser usada retoricamente para a defesa de qualquer tese. ${ }^{221}$

Com efeito, é necessário apreender a noção acerca da diferença entre princípios e regras, sua importância e a forma com que ambos os institutos coexistem no ordenamento jurídico, sob pena de se reduzir a análise das relações entre particulares à tutela do princípio da dignidade da pessoa humana e seus desdobramentos, descurandose do fato de que as relações intersubjetivas envolvem situações de incomensurável diversidade, fonte de efeitos jurídicos verdadeiramente dinâmicos e complexos.

A consciência da complexidade dessas relações e das múltiplas faces do direito privado deve excluir a ideia de uma resposta final e única, que se resuma, apenas, a perquirir sobre a forma de incidência dos princípios constitucionais nos casos

219 Pietro Perlingieri, Perfis do direito civil: introdução ao direito civil constitucional, cit., p. 34.

220 Ao discorrer sobre um modelo de Constituição total, Virgílio Afonso da Silva ressalva a "pena irônica de Forsthoff, em que tudo seria definido pela constituição, até mesmo a produção de termômetros para a febre" (A constitucionalização do direito. Os direitos fundamentais nas relações entre particulares, cit., p. 113).

221 "O Direito do século XXI não se contenta com os conceitos axiológicos formais que podem ser usados retoricamente para qualquer tese. Mal o século XX se livrou do vazio do bando dos quatro os quatro conceitos jurídicos indeterminados: função social, ordem pública, boa-fé, interesse público -, preenchendo-se, pela lei, doutrina e jurisprudência, com alguma diretriz material, que surge agora no século XXI, problema idêntico com a expressão "dignidade da pessoa humana" (Antonio Junqueira de Azevedo, Caracterização jurídica da dignidade da pessoa humana, cit., p. 3). 
concretos, o que afinal pode redundar na própria banalização da Constituição e na perda de sua força normativa. ${ }^{222}$

Deste modo, verifica-se que a eficácia dos direitos fundamentais e dos princípios constitucionais no âmbito das relações entre particulares envolve questões que devem ser analisadas de maneira mais aprofundada para que se possa desenvolver o tema objeto da presente tese, posto envolver, em sua essência, a liberdade de informar e a de manter-se informado, assim como as consequências jurídicas dessa troca de informações, conselhos e recomendações.

\subsection{A eficácia dos princípios constitucionais no âmbito das relações de direito privado}

Apesar da verdadeira revolução levada a efeito em nosso ordenamento jurídico com o advento da Constituição de 1988, caracterizada pela superação da antiga concepção liberal ancorada essencialmente em normas dirigidas à proteção patrimonial, para a adoção de um novo paradigma existencialista que apresenta como valor fundamental a tutela da pessoa humana, a ordem constitucional ainda suscita inúmeras controvérsias, especialmente no que tange à eficácia dos direitos fundamentais no âmbito das relações de direito privado.

Na opinião de Claus-Wilhelm Canaris, os direitos fundamentais devem ser levados ao nível de "direito imediatamente vigente" e não de "meras asserções programáticas", inclusive para o legislador de direito privado. Além disso, as normas de direito privado podem servir para a concretização de imperativos de tutela de direitos fundamentais, consoante bem salienta o catedrático da Universidade de Munique. ${ }^{223}$

Outrossim, ressalva Canaris que "o direito privado é apenas direito ‘ordinário', e está, enquanto tal, na estrutura hierárquica da ordem jurídica, num plano

\footnotetext{
222 Jorge Reis Novais, Direitos fundamentais: trunfos contra a maioria, Coimbra: Coimbra Ed., 2006, p. 113.

223 Claus-Wilhelm Canaris, Direitos fundamentais e direito privado, Coimbra: Almedina, 2006, p. 2324.
} 
sob a Constituição”. Por conseguinte, segundo o princípio da primazia da Lex superior, a legislação de direito privado está vinculada à tutela dos direitos fundamentais e aos princípios constitucionais que compõem a ordem de valores trazida pela Lei Maior. ${ }^{224}$

Neste contexto, deve-se ressaltar que os princípios constitucionais trazem consigo valores fundamentais do ordenamento jurídico, impondo-se a interpretação e aplicação da norma sob a sua égide. ${ }^{225}$

Esse entendimento, no entanto, não é livre de críticas. Pelo contrário, diversas são as teorias que pretendem estabelecer critérios acerca da irradiação dos direitos fundamentais nas relações entre particulares, em especial por levarem em consideração a função clássica desses direitos, caracterizada pela necessidade de proteção do cidadão contra violações perpetradas pelo Estado.

De fato, fundamento básico do liberalismo consiste na estreita separação entre o público e o privado e na tutela da autonomia da vontade e da liberdade contratual enquanto princípios fundamentais, a serem protegidos contra toda e qualquer interferência do Estado. ${ }^{226}$

224 Claus-Wilhelm Canaris, Direitos fundamentais e direito privado, Coimbra: Almedina, 2006, p. 2728.

225 "Os princípios constitucionais, assegurada a hierarquia das normas, são os mais relevantes e contêm os valores que devem estar presentes em cada interpretação-aplicação de regras ou de princípios setoriais. Se uma regra pode ser referida a pelo menos um princípio, há quase uma pluralidade e princípios que precisam ser confrontados quando da realização do procedimento de interpretação. Esta análise, comumentemente chamada de ponderação ou balanceamento, é devida ao fato de que os princípios, ao contrário das regras, constituem uma pluralidade e jamais se excluem mutuamente, havendo, como resultado da interpretação, apenas uma ordenação de preferência (ou uma eventual compatibilização entre eles), instaurando-se, em relação ao caso concreto, uma 'hierarquização axiológica"" (Maria Celina Bodin de Moraes, Apresentação à obra: Princípios do direito civil contemporâneo (Coord. Maria Celina Bodin de Moraes), Rio de Janeiro: Renovar, 2006. p. IX).

226 Juan María Bilbao Ubillos observa que, em um regime liberal, a serviço dos interesses da burguesia, as liberdades só se protegem diante do que se percebe como sua maior ameaça, as possíveis interferências do poder político. Dessa forma, são os poderes públicos e a Administração, em primeiro lugar, os inimigos potenciais das recém-conquistadas liberdades. "En ese marco, un régimen liberal al servicio de los intereses de la burguesía, las libertades sólo se protegen frente a lo que se percibe como su principal amenaza, las posibles interferencias del poder político. Son los poderes públicos, y la Administración en primer lugar, los enemigos potenciales de las recién conquistadas libertades” (¿En qué medida vinculan a los particulares los derechos fundamentales?, in: Ingo Wolfgang Sarlet [Org.], Constituição, direitos fundamentais e direito privado, 2. ed., Porto Alegre: Livraria do Advogado, 2006, p. 302). 
Neste sentido, Juan María Bilbao Ubillos salienta a marcante separação entre o Estado e a sociedade como um dos postulados básicos do liberalismo, observando caber ao Código Civil o papel de verdadeira carta constitucional dessa sociedade liberal e autossuficiente, em que se sancionam os princípios da autonomia da vontade e da liberdade contratual como eixo da regulação das relações jurídicas entre particulares. Neste modelo, careceria de sentido estender a eficácia dos direitos individuais às relações entre particulares, posto estabelecerem-se, por princípio, entre iguais. $^{227}$

Por conseguinte, os direitos fundamentais, em sua origem histórica, eram exercidos contra o Estado, como garantia da liberdade individual e em reação à excessiva intervenção estatal característica do absolutismo - no que se convencionou chamar de primeira geração ou de primeira dimensão -, reservando-se um espaço livre da ingerência do poder público, capaz de permitir o desenvolvimento das relações entre particulares e consagrar a autonomia privada.

No entanto, a redução do papel do Estado, decorrente da reação da burguesia contra os excessos do estado absolutista, e a consequente distensão do liberalismo, fundada na ideia de que as relações entre particulares não devem sofrer a intervenção estatal nem ser objeto de quaisquer limitações, acabaram por se transformar em fonte de iniquidades e em objeto a serviço de uma classe dominante para a perpetuação de seu status quo.

A transformação das relações sociais e comerciais e o avanço tecnológico propiciaram a acumulação de riquezas nas mãos de alguns, permitindo a exploração da mão de obra de um sem-número de pessoas e demonstrando que a ideia de uma mão invisível capaz de trazer o equilíbrio nas relações entre particulares não passava de ideal

227 "El Código Civil se erige entonces en la verdadera carta constitucional de esa sociedad autosuficiente, sancionando los principios de la autonomía de la voluntad e de la libertad contractual como ejes de la regulación de las relaciones jurídicas inter privados. Carece de sentido extender a este tipo de relaciones la eficacia de los derechos individuales se éstas se establecen, por principio, entre iguales, porque entre iguales las relaciones no pueden ser sino libres" (Juan María Bilbao Ubillos, “¿En qué medida vinculan a los particulares los derechos fundamentales?”, cit., p. 302). 
bastante dissociado da realidade. ${ }^{228}$ A igualdade formal, pedra fundamental do liberalismo, não se concretizava no plano fático.

Surge, então a necessidade de revisão desse modelo, para um novo, em que o significado da ordem jurídico-estatal não se esgote "no asseguramento de princípios do direito e na mera restrição do poder estatal em favor da liberdade do particular". 229 Torna-se necessário que o Estado exerça sua atividade com vistas a reconhecer e garantir o exercício dos direitos fundamentais por parte dos cidadãos, através de prestações sociais capazes de garantir a todos o acesso a uma vida digna, permitindo à comunidade alcançar um elevado grau de solidariedade.

Nesse diapasão, amplia-se a função do Estado, para consagrar sua necessária intervenção na economia - que passa a integrar a esfera da política -, bem como nas relações intersubjetivas, em busca do cumprimento de tarefas sociais impostas pela atual dinâmica das relações comerciais, bem como pelos reflexos de um avanço tecnológico outrora inimaginável.

Mais do que uma administração intervencionista, impôs-se a efetivação de uma administração prestacionista, em que o Estado deve exercer tarefas de configuração, assistência social e previsão planificadora ampla, tudo a serviço de um objetivo maior: o asseguramento da existência digna do ser humano. ${ }^{230}$

Essa transformação torna imperiosa a tutela dos direitos fundamentais, não só no âmbito da relação Estado-indivíduo, como reflexo apenas da proteção da autonomia privada contra uma ordem jurídica estatizante e absolutista, mas também no

228 "A vida mostraria não corresponder à realidade a velha tese liberal de que a economia e a sociedade, confiadas à mão invisível (às leis naturais do mercado), proporcionam a todos os indivíduos, em condições de liberdade igual para todos, as melhores condições de vida, para além do justo e do injusto. Este pressuposto liberal - que justificava a tese de que o estado deveria estar separado da sociedade e da economia - falhou em virtude de vários factores: o progresso técnico, aumento da dimensão das empresas, concentração do capital, fortalecimento de movimento operário (no plano sindical e no plano político) e agravamento da luta de classes; aparecimento de ideologias negadoras do capitalismo" (Antonio José Avelãs Nunes, O Estado capitalista. Mudar para permanecer igual a si próprio, in: Francisco José Rodrigues de Oliveira Neto et al. (Org.), Constituição e Estado Social: os obstáculos à concretização da Constituição, São Paulo: RT/Coimbra: Ed. Coimbra, 2008, p. 49). 
eixo das relações privadas, a fim de garantir a construção de uma sociedade mais justa, equânime e solidária.

Dessa forma, busca-se a concretização do solidarismo social e da justiça distributiva, bem como a tutela da dignidade humana, ressaltando-se a função promocional do direito.

Neste sentido, Norberto Bobbio observa que "a passagem do Estado Liberal para o Estado Social é assinalada pela passagem de um direito com função predominantemente protetora-repressiva para um direito cada vez mais promocional". 231

Assim, os direitos fundamentais adquirem, também, natureza prestacional, em que a efetiva extensão e amplitude de sua tutela deve atingir a todos os ramos do ordenamento jurídico, notadamente no que tange às relações entre particulares.

Sob esse prisma, o direito privado não constitui um universo autônomo infenso à projeção das normas constitucionais e de sua base axiológica, para o qual as diretrizes constitucionais não passariam de meras asserções programáticas e não vinculativas.

Contudo, a irradiação dos direitos fundamentais sobre as relações de direito privado se efetiva através de um processo altamente complexo e dinâmico, fonte de intenso debate doutrinário, que acaba por repercutir em nossos tribunais, e possui relevância para o desenvolvimento de nossa tese, que versará sobre diversos princípios de nosso ordenamento, para que torne possível demonstrar os fundamentos de uma responsabilidade pela confiança em nosso sistema jurídico.

Sobre o tema, Virgílio Afonso da Silva faz acurada análise, cingindo a questão, em síntese, aos seguintes modelos básicos: um primeiro que consistiria na recusa de quaisquer efeitos dos direitos fundamentais fora do âmbito das relações entre

231 Norberto Bobbio, O futuro da democracia, tradução de Marco Aurélio Nogueira, São Paulo: Paz e Terra, 2000, p. 126. 
Estado-cidadãos; outro que se sustenta na eficácia indireta dos direitos fundamentais nas relações entre particulares; e um terceiro, fundamentado na produção de efeitos diretos dos direitos fundamentais nas relações entre cidadãos. Além desses três modelos, o autor ressalta a existência de uma quarta possibilidade, que consistiria na "imputação das ações particulares ao estado ou a equiparação dessas ações estatais". ${ }^{232}$

Pelo modelo que nega a possibilidade de produção de efeitos dos direitos fundamentais nas relações entre particulares, a norma constitucional encontra-se em posição hierarquicamente superior em relação ao direito privado, mas isso não significa necessariamente a supremacia de sua base axiológica sobre os demais ramos do direito. Segundo esse entendimento, os valores constitucionais não adquirem status superior pelo simples fato de estarem previstos na Constituição, mas devem ser aplicados em concorrência com as disposições de direito privado. ${ }^{233}$

Por outro lado, o modelo dos efeitos indiretos dos direitos fundamentais nas relações entre particulares funda-se no reconhecimento de um direito geral de liberdade que impediria um efeito absoluto nas relações privadas, capaz de significar o domínio total do direito constitucional sobre o direito privado. Assim, os sujeitos de uma relação jurídica de direito civil devem ser livres para relativizar a aplicação de direitos fundamentais, levando-se em consideração a autonomia privada e a responsabilidade individual. Não se trata, todavia, de uma liberdade absoluta, que ensejaria uma clivagem incontornável entre o direito público e o direito privado, voltando-se ao primeiro modelo antes exposto, mas sim de uma forma capaz de promover a conciliação entre ambos, sem que haja o domínio de um pelo outro. A solução se daria pelo próprio material normativo do direito privado, a base dos efeitos indiretos, em que se "pressupõe a ligação de uma concepção de direitos fundamentais como um sistema de valores com a existência de portas de entrada desses valores no próprio direito privado, que seriam as cláusulas gerais". 234

\footnotetext{
232 Virgílio Afonso da Silva, A constitucionalização do direito. Os direitos fundamentais nas relações entre particulares, cit., p. 66-106.

233 Idem, ibidem, p. 71-72.

234 Idem, p. 75-76.
} 
Outrossim, há o modelo da aplicabilidade direta dos direitos fundamentais nas relações entre particulares, cuja base se alicerça na ideia de não ser necessária nenhuma ação intermediária do legislador ordinário para que sejam aplicados nas relações de direito privado, bastando que se desse o mesmo tratamento destinado às relações entre o Estado e os cidadãos. Isso porque os diretos fundamentais possuem efeitos absolutos, conferindo direitos subjetivos diretamente aos particulares e tornando desnecessária qualquer intermediação legislativa para que pudessem ser aplicados no âmbito das relações privadas. ${ }^{235}$

Jorge Reis Novaes, por sua vez, aponta a existência, em síntese, de três teses que se destinam a solucionar a questão acerca da eventual eficácia dos direitos fundamentais "quando não há lei ordinária que regule especificamente a situação controvertida ou quando o problema não é adequadamente resolúvel através da interpretação jusfundamentalmente conforme das cláusulas gerais": eficácia mediata, deveres de proteção e eficácia imediata. ${ }^{236}$

De acordo com seu entendimento, as teses da eficácia mediata e da eficácia imediata "são peremptórias e claramente opostas", posto que a primeira recusa qualquer efeito suplementar produzido pelos direitos fundamentais com apoio nas normas constitucionais, ao passo que na segunda aplicar-se-ão os direitos fundamentais consagrados constitucionalmente na qualidade de direito subjetivo oponível a outros particulares, o que significa "sua dimensão de vinculatividade jurídica mais ambiciosa". ${ }^{237}$

Já a tese dos deveres de proteção apresenta maior complexidade, eis que recusa a aplicação direta dos direitos fundamentais, como a doutrina da eficácia mediata, mas sustenta algum outro tipo de eficácia dos direitos fundamentais nas relações privadas, convergindo com a tese da eficácia imediata. Em sua acepção, os direitos fundamentais projetam efeitos jurídicos sobre as relações privadas através do

\footnotetext{
235 Virgílio Afonso da Silva, A constitucionalização do direito. Os direitos fundamentais nas relações entre particulares, cit., p. 87-89.

236 Jorge Reis Novais, Direitos fundamentais: trunfos contra a maioria, cit., p. 74.

237 Idem, ibidem, p. 75.
} 
reconhecimento de sua dimensão objetiva, de onde decorrem especiais deveres de proteção, dirigidos a todos os poderes do Estado - inclusive o Judiciário -, tornando possível ao juiz recorrer à norma constitucional para resolver conflitos entre particulares, toda vez que o legislador não tenha cumprido adequadamente com os seus deveres e que a proteção dos direitos fundamentais assim o exija. ${ }^{238}$

Daniel Sarmento faz esmerado estudo sobre as diversas teorias acerca da eficácia dos direitos fundamentais nas relações privadas, dividindo-as em quatro grupos: a) teorias negativas; b) teoria da eficácia indireta e mediata; c) teoria da eficácia direta e imediata; e d) teorias alternativas e mistas. ${ }^{239}$

Segundo Sarmento, a tese que nega vinculação dos particulares aos direitos fundamentais previstos pela norma constitucional teve sua maior difusão nos Estados Unidos, constituindo "praticamente um axioma do Direito Constitucional norteamericano, quase universalmente aceito tanto pela doutrina como pela jurisprudência" como paradigma da defesa da liberdade individual, difundindo-se a ideia que no Bill of Rights da Carta americana os direitos fundamentais "impõem limitações apenas para os Poderes Públicos e não atribuem para os particulares direitos frente a outros particulares, com exceção apenas da $13 .{ }^{\text {a }}$ Emenda, que proibiu a escravidão". ${ }^{240}$

De acordo com o autor, a denominada doutrina da state action, associada de maneira profunda ao radical individualismo característico da Constituição norteamericana e a cultura geral dos Estados Unidos, deixa de proporcionar "um tratamento adequado aos direitos fundamentais, diante do fato de que os maiores perigos e ameaças não provêm do Estado", apesar dos "erráticos temperamentos que a jurisprudência lhe introduziu". 241

238 Jorge Reis Novais, Direitos fundamentais: trunfos contra a maioria, cit., p. 74.

239 Daniel Sarmento, Direitos fundamentais e relações privadas, 2. ed. (2. tir.), Rio de Janeiro: Lumen Juris, 2008, p. 187.

240 Idem, ibidem, p. 189.

241 Idem, p. 196-197. Em opinião contrária, Virgílio Afonso da Silva sustenta que o entendimento jurisprudencial norte-americano acaba por acolher alguma forma de vinculação dos direitos fundamentais sobre as relações privadas: "Parece-me aconselhável, portanto, distinguir aquilo que a doutrina norte-americana em parte sustenta e aquilo que é coerente com a jurisprudência da Suprema 
Ao discorrer sobre a teoria da eficácia indireta ou mediata, por seu turno, Daniel Sarmento explica que seus defensores sustentam a proteção dos direitos fundamentais no campo das relações privadas através de mecanismos típicos do direito Privado e não dos instrumentos do direito constitucional, posto negar-se a possibilidade de sua aplicação direta nas relações entre particulares porque "esta incidência acabaria exterminando a autonomia da vontade". Dessa forma, caberia ao legislador privado mediar a aplicação dos direitos fundamentais na esfera privada, "mas sem descurar-se da tutela da autonomia da vontade", restando ao Poder Judiciário o papel de preencher as cláusulas indeterminadas criadas pela legislação ordinária, bem como "rejeitar, por inconstitucionalidade, a aplicação das normas privadas incompatíveis com tais direitos". 242

Sobre a eficácia direta e imediata dos direitos fundamentais, observa que seus adeptos não defendem uma teoria radical nem pregam que a liberdade individual seja desconsiderada no tráfego jurídico privado, posto não negarem a existência de especificidades nessa incidência, nem a necessidade de promover uma ponderação desses direitos com a autonomia privada. ${ }^{243}$ Declarado adepto dessa teoria, Sarmento ressalva expressamente que "o reconhecimento da vinculação direta dos particulares aos direitos fundamentais não significa que tais direitos possam ser aplicados nas relações privadas da mesma forma que vigoram nas relações entre cidadãos e Estado", impondose uma série de adaptações para que essa incidência se efetive no campo privado. ${ }^{244}$

Por outro lado, na sequência de sua explanação, o autor ressalta a existência da teoria dos deveres de proteção, observando tratar-se de uma variação da teoria da eficácia indireta, que, fundamentalmente, sustenta-se na ideia de que cabe ao Estado a proteção dos direitos fundamentais dos particulares ameaçados pela conduta de outros

Corte. Por isso, ainda que se insista que, nos Estados Unidos, os direitos fundamentais somente vinculam as autoridades estatais, a prática jurisprudencial tem mostrado uma outra realidade, ainda que encoberta: a de que os direitos fundamentais vinculam, de alguma forma, os indivíduos nas suas relações entre si" (A constitucionalização do direito. Os direitos fundamentais nas relações entre particulares, cit., p. 87-89.

242 Daniel Sarmento, Direitos fundamentais e relações privadas, cit., p. 197-204.

243 Idem, ibidem, p. 205.

244 Idem, p. 259. 
particulares. Tal tese, no entanto, pecaria pela contradição, pois só faria sentido obrigar o Estado a impedir uma lesão a um direito fundamental causada por particular se também pudesse ser aceito o fato de que ao particular não seria lícito causar referida lesão, o que significa dizer que ele também está vinculado a respeitar o direito fundamental. $^{245}$

Por fim, em análise às diversas teorias alternativas, Daniel Sarmento salienta a existência da designada "teoria da convergência estatista", pela qual o Estado seria sempre o responsável último pelas lesões a direitos fundamentais originários das relações entre particulares. Ressalva ainda a posição sustentada por Robert Alexy em sua Teoria dos direitos fundamentais, pela qual pretende a conciliação de três correntes aparentemente divergentes: a teoria da eficácia direta e imediata, a teoria da eficácia indireta e imediata e a doutrina dos deveres de proteção do Estado. ${ }^{246}$

De fato, Robert Alexy constrói um modelo em três níveis para os efeitos perante terceiros, afirmando ser falsa a ideia de que uma corrente tivesse que ser necessariamente correta, pois somente uma teoria que abarque todos os aspectos seria capaz de oferecer uma solução completa e adequada para a questão. Por essa razão, cria um modelo composto por três níveis: $i$ ) o nível do dever estatal; ii) o nível dos direitos em face do Estado; e iii) o nível das relações jurídicas entre sujeitos privados. ${ }^{247}$

Pelo modelo construído pelo mestre da Universidade de Kiel, no nível do dever estatal situa-se a teoria dos efeitos indiretos, pois o fato de as normas de direitos fundamentais valerem como princípios objetivos, ou seja, uma ordem objetiva de valores para todos os ramos do direito, leva ao dever do Estado de levar referidas normas em consideração tanto na jurisprudência como na legislação civil. Já para o nível dos direitos em face do Estado aplicar-se-ia a teoria dos deveres de proteção, enquanto uma construção explicitamente referida à jurisdição, no sentido de conferir ao cidadão um direito em face da jurisdição civil, que deve considerar o princípio de

245 Daniel Sarmento, Direitos fundamentais e relações privadas, cit., p. 216-220.

246 Idem, ibidem, p. 220-224.

247 Robert Alexy, Teoria dos direitos fundamentais, tradução de Virgílio Afonso da Silva, São Paulo: Malheiros, 2008, p. 533. 
direito fundamental favorável à posição alegada pelo cidadão, na medida do exigível. ${ }^{248}$ O terceiro nível do modelo, por sua vez, refere-se aos efeitos dos direitos fundamentais nas relações jurídicas entre particulares, em que se aplica a teoria da eficácia imediata. $^{249}$

Em nossa opinião, no âmbito das relações privadas existe vinculação direta dos particulares aos direitos fundamentais, aplicando-se a teoria da eficácia imediata, o que autoriza o magistrado a recorrer à norma constitucional para a solução do conflito, sempre que houver violação a referidos direitos.

Contudo, esse recurso à norma constitucional por parte do magistrado não pode ser realizado de maneira completamente apartada de nosso sistema, que se encontra fundado em princípios e regras, razão pela qual se faz necessário proceder à análise dos fundamentos do sistema jurídico brasileiro, e da opção do legislador por um sistema aberto, em que princípios e regras coexistem e se integram.

Isso porque o tema atinente ao princípio da boa-fé objetiva e à teoria da confiança apresenta especial importância para a conclusão desta tese, mas não se deve proceder ao seu estudo através de uma perspectiva generalizante e sem nenhuma preocupação metodológica.

Com efeito, sempre que perquiridos acerca do tema escolhido para a nossa tese de doutoramento, ouvia-se do interlocutor um comentário genérico de que tudo terminaria em uma conclusão relacionada à boa-fé. Esse fato, reiterado, acabou por causar um incômodo considerável, pois foi possível verificar que o princípio da boa-fé objetiva vem sendo tratado de forma completamente abstrata e abrangente, como se fosse uma verdadeira panaceia para todos os males.

248 Sobre o tema, Robert Alexy faz a seguinte ressalva: "A construção referida à jurisdição não pode ser acusada de uma subjetivação não justificada dos deveres do Judiciário. Ela não confere ao indivíduo um direito a todos os resultados da atividade jurisdicional sejam, em todos os aspectos, conformes aos direitos fundamentais, nem um direito a que eles sejam pura e simplesmente corretos; ela confere tão somente um direito a que os princípios de direitos fundamentais favoráveis à sua posição sejam levados em consideração na medida do exigível" (Teoria dos direitos fundamentais, cit., p. 538).

249 Idem, ibidem, p. 533-542. 
De fato, no meio jurídico de hoje é possível verificar uma anódina unissonância em torno do princípio da boa-fé objetiva, alçado ao panteão das soluções para todos os problemas, posto que qualquer fato seria capaz de significar afronta aos seus ditames. ${ }^{250}$

O que se vê na verdade é uma discussão estéril e desprovida de método e de fundamento, em que a palavra princípio é utilizada de maneira pouco apegada à técnica $^{251}$ e os seus efeitos são manipulados de acordo com a tese momentaneamente defendida.

Por essa razão, impõe-se tecer considerações acerca do sistema jurídico brasileiro, para se consolidar o alicerce mínimo necessário à conclusão do presente trabalho, a fim de se efetivar uma adequada aplicação do princípio da boa-fé objetiva aos problemas decorrentes da troca de informações, conselhos e recomendações entre particulares, sempre em consonância com a base valorativa de nosso ordenamento, tornando possível a construção dos fundamentos de uma responsabilidade pela confiança, cerne de nossa tese.

\subsection{A base valorativa do sistema brasileiro e os mecanismos para a sua abertura: princípios, conceitos legais indeterminados e cláusulas gerais}

A presente tese, que se funda eminentemente na base teleológica e axiológica de nossa ordem jurídica e apoia-se em um método jurídico-dogmático, não busca uma única resposta para a questão decorrente da responsabilidade pelas informações, conselhos e recomendações, mas a solução mais adequada ao nosso sistema.

250 “A boa-fé objetiva aparece hoje, não obstante os propósitos meritórios de sua aplicação, como fundamento de soluções a que se chegaria, de forma mais eficaz e mais adequada à luz do próprio sistema jurídico, pela aplicação direta de princípios constitucionais, ou até regras específicas do direito privado" (Anderson Schreiber, A proibição de comportamento contraditório. Tutela da confiança e venire contra factum proprium, cit., p. 121).

251 Neste sentido, Anderson Schreiber atenta para o que denomina de superutilização da boa-fé objetiva, expressão que deve ser entendida para "designar um processo de invocação arbitrária da boa-fé como justificativa ética de uma série de decisões judiciais e arbitrais, que nada dizem tecnicamente com seu conteúdo e suas funções" (ibidem, p. 121). 
Por essa razão, a solução aqui apresentada parte da base valorativa de nosso ordenamento, sem se descurar do direito positivo pátrio, a fim de encontrar uma solução que se adapte coerentemente ao sistema jurídico atual.

Isso porque o fenômeno jurídico não deve ser estudado apenas como norma, relação ou instituição, aspectos que lhe são fundamentais, mas que apenas fragmentam o entendimento se estudados de forma unilateral, pois o direito deve ser apreciado com uma visão global e compreensiva da totalidade formada com as normas, as relações, as instituições, todas elas integradas por um conjunto coerente, unitário e dinâmico, processado sob a égide de valores e de princípios fundamentais. ${ }^{252}$

Existe uma base moral em todo sistema jurídico que não pode ser ignorada nem relevada a um plano secundário. ${ }^{253}$ Neste sentido, ensina Jürgen Habermas que os discursos jurídicos não podem movimentar-se apenas em um universo fechado de regras jurídicas inequivocamente fixadas, em virtude da estratificação do direito moderno em regras e princípios, e devido ao fato de muitos desses princípios possuírem, simultaneamente, uma natureza jurídica e moral, o que se deduz facilmente no direito constitucional. Assim, os princípios morais do direito natural tornaram-se direito positivo no Estado constitucional. ${ }^{254}$

Essa base moral do sistema serve de norte para as ações do legislador, do magistrado e da doutrina, assim como de vetor fundamental para as relações entre particulares e não pode estar dissociada de seu alicerce histórico-cultural. ${ }^{255}$

252 Francisco Amaral, Direito civil: introdução, 7. ed., cit., p. 40.

253 “A Moral, apesar de todo o relativismo que nela se queira introduzir, existe e condiciona a vida que o Direito legitima. Além disso, sublinha-se hoje que alguns dos seus princípios são objetivamente demonstráveis, com ganhos evidentes para uma interpenetração com certos níveis jurídicos de decisão" (António Manuel da Rocha e Menezes Cordeiro, Introdução à edição portuguesa da obra de Claus-Wilhelm Canaris, Pensamento sistemático e conceito de sistema na ciência do direito, 4. ed., tradução de António Menezes Cordeiro, Lisboa: Fundação Calouste Gulbenkian, 2008, p. XXXIII).

254 Jürgen Habermas, Direito e moral, tradução de Sandra Lippert. Lisboa: Instituto Piaget, 1999, p. 33.

255 "É a regra moral - variável de acordo com as épocas ou as sociedades - que vai guiar os homens primeiro interagindo em sociedade, mas igualmente o legislador, o juiz e a doutrina." No original: “C'est la régle morale - variable selon lês époques ou lês sociétés - qui va guider les hommes pris en tant qu'acteurs du groupe, ma également le législateur, le juge et la doctrine" (Stéphane Darmaisin, Le contrat moral, Paris: Librairie Générale de Droit et de Jurisprudence, p. 30). 
Assim, não se deve dissociar o estudo do direito privado da base valorativa de nosso ordenamento nem de seus princípios fundamentais, mas proceder à sua análise através do sistema jurídico posto e de sua relação com os diversos outros sistemas que compõem a vida social, tais como o político, o econômico e o cultural.

Dessa forma, o magistrado e o legislador devem retomar os valores fundamentais do sistema, procedendo com adequação e agindo de acordo com as exigências ético-jurídicas que radicam na própria ideia de direito. ${ }^{256}$

Não se está aqui a defender uma abordagem completamente apartada do direito positivo, desprovida de método e que intente se sustentar em um alicerce eminentemente valorativo, fundando sua argumentação apenas em princípios e na forma como se efetivam em nosso ordenamento.

Pelo contrário, em momentos anteriores já criticamos as concepções generalizantes, por meio das quais tudo se resolve apenas pelos princípios constitucionais, em que a ideia de valores, o seu conceito e extensão são manipulados de acordo com as conclusões a priori pretendidas, partindo-se de uma frágil base científica, dissociada da técnica e de todo o processo secular de construção da ciência do direito.

De fato, é cediço que o direito possui uma natureza cultural ${ }^{257}$ indissociável da natureza humana e que vai se formando ao longo dos tempos, de acordo com o quadro de valores característico de cada civilização, em um contínuo processo de construção de patamares axiológicos no curso da história. ${ }^{258}$

256 Claus-Wilhelm Canaris, Pensamento sistemático e conceito de sistema na ciência do direito, 4. ed., tradução de António Menezes Cordeiro, Lisboa: Fundação Calouste Gulbenkian, 2008, p. 18.

257 “A natureza cultural do Direito, herança irrepudiável da escola histórica, coloca a ordem jurídica na categoria das criações humanas, configuradas por evolução paulatina e por uma complexidade causal que as torna imprevisíveis e insubsumíveis em modelos rígidos de lógica formal. Nesta dimensão, o Direito é um fenômeno pré-dado: o jurista deve apreendê-lo, do exterior, tal com ele se encontra, de acordo com coordenadas históricas e geográficas" (António Menezes Cordeiro, Introdução à edição portuguesa da obra de Claus-Wilhelm Canaris, Pensamento sistemático e conceito de sistema na ciência do direito, cit., p. LXI).

258 Miguel Reale, Nova fase do direito moderno, São Paulo: Saraiva, 1990, p. 45. 
No entanto, esse processo de construção dos chamados patamares axiológicos demanda uma apurada análise científica, a fim de verificar se obedecem a uma lei evolutiva, ou se surgem e se constituem sem qualquer elo entre eles - ou até mesmo por acaso -, o que ressalva a importância da ciência do Direito e de uma estruturação científica das decisões. ${ }^{259}$

É exatamente na ponderação entre a natureza histórico-cultural do Direito e a estruturação científica de suas decisões que residirá toda a harmonia do sistema, que não pode estar pautado apenas por uma concepção valorativa generalizante, sem um alicerce formado por regras capazes de permitir a concretização de seus princípios gerais.

Esse contraponto entre princípios e regras possui relevância fundamental para o equilíbrio do sistema, assim como representa um importante mecanismo para a solução de problemas centrais decorrentes da forma como os valores fundamentais de nosso ordenamento permeiam-se nas relações privadas. Todavia, não se trata de questão alheia a controvérsias, relacionadas ao seu conceito e extensão, o que demanda sua análise mais pormenorizada.

De início, deve-se alertar para o fato de não haver um conceito único de princípio ou uma definição geral, ${ }^{260}$ posto tratar-se de um vocábulo polissêmico que ora pode significar o início de algo, ora pode ter o sentido de valor e até mesmo aparecer como diretriz ética ou jurídica, como acontece com a boa-fé. ${ }^{261}$

Entretanto, interessa ao presente estudo a concepção normativa dos princípios e a sua particular constituição, capaz de diferenciá-los das regras, tornando-

259 Miguel Reale, Nova fase do direito moderno, cit., p. 45.

260 "O conceito de princípio jurídico, assim como o de direito é demasiadamente complexo para admitir, de início, uma definição unitária. É assim, conceito que admite várias acepções, por exemplo, como norma programática ou diretriz (CR, art. 5. $\left.{ }^{\circ}, \mathrm{XXXII}\right)$, como expressão de valores supremos de uma ordem jurídica, por exemplo, a igualdade (CR, Preâmbulo), como regra jurídica que serve de fundamento à sistematização de um determinado setor de direito, por exemplo, o princípio da dignidade da pessoa humana (CR, art. 1. ', III)" (Francisco Amaral, Direito civil: introdução, 7. ed., cit., p. 61).

261 Teresa Ancona Lopez, Princípio da precaução e evolução da responsabilidade civil, cit., p. 78. 
os, "uma vez constitucionalizados, a chave de todo o sistema normativo", consoante bem ressalva Paulo Bonavides. ${ }^{262}$

Sobre o tema, Robert Alexy adverte para o fato de a distinção entre princípios e regras não ser nova, além de ser fonte de polêmica e de falta de clareza, em virtude de uma desconcertante pluralidade de critérios distintivos e de uma terminologia vacilante e obscura. Segundo seus ensinamentos, tanto os princípios como as regras são normas, posto estabelecerem "o que deve ser", podendo ser formulados por meio de expressões deônticas básicas do dever, da permissão e da proibição. Contudo, consistem em duas espécies distintas de normas: a) os princípios são normas que ordenam a realização de algo na maior medida possível dentro das possibilidades fáticas e jurídicas existentes, constituindo mandamentos de otimização, caracterizados em razão da possibilidade de serem satisfeitos em graus variados, além de a medida devida de sua satisfação não depender somente das possibilidades fáticas, mas também das possibilidades jurídicas; b) as regras, por sua vez, consistem em normas que são sempre satisfeitas ou não satisfeitas, impondo que se faça exatamente o que ela exige, nem mais nem menos, posto conterem determinações no âmbito daquilo que é jurídica e faticamente possível. Por conseguinte, a distinção entre regras e princípios é qualitativa e não uma distinção de graus, em que toda norma ou é um princípio ou é uma regra. ${ }^{263}$

Muito embora existam abalizados entendimentos ${ }^{264}$ contrários, seguiremos a lição Robert Alexy, por julgarmos a opção metodológica mais adequada para o desenvolvimento de nossa tese.

Paulo Bonavides, Curso de direito constitucional, 24. ed., São Paulo: Malheiros, 2009, p. 258.

263

Robert Alexy, Teoria dos direitos fundamentais, cit., p. 86-91.

264 Confira-se, por exemplo, as opiniões de Ronald Dworkin (Levando os direitos a sério, 2. ed., Tradução de Nelson Boeira, São Paulo: Martins Fontes, 2007, p. 39) ou de Friedrich Müller (Teoria estruturante do direito, Tradução de Peter Naumann e Eurides Avance de Souza, São Paulo: RT, 2008). 
Desse modo, pode-se perceber que os princípios constituem diretrizes básicas e gerais do ordenamento, não obstante apresentarem um maior grau de concretização do que os valores. ${ }^{265}$

Na precisa lição de Karl Larenz os princípios são os pensamentos diretores de uma regulamentação jurídica existente ou possível. ${ }^{266}$

Neste sentido, observa Francisco Amaral que os princípios contêm um pensamento jurídico diretor ou condutor, orientando o intérprete no processo de criação da norma jurídica, servindo, assim, de garantia e de certeza a um conjunto de juízos, bem como para fundamentar e dar unidade a uma instituição ou a um sistema. ${ }^{267}$

De acordo com seus ensinamentos, os princípios podem ser classificados como suprapositivos, quando transcendentais e estruturantes dos diversos domínios do ordenamento jurídico, ou positivos, que são aqueles enunciados expressamente pelo direito vigente. Os princípios suprapositivos são os grandes princípios, expressões jurídicas dos valores fundamentais, que consistem em valores não expressos em lei, orientando o intérprete no caso de omissão do texto legal e traduzindo o último recurso quando o ordenamento jurídico é lacunoso e incompleto. Já os princípios positivos compreendem os a) princípios fundamentais (constitucionais ou superiores), base essencial para a construção da ordem jurídica e que possuem força normativa, com aplicação preferencial sobre qualquer norma ordinária; e b) princípios institucionais, que fundamentam os variegados institutos jurídicos que compõem o sistema, tais como

265 "A passagem do valor para o princípio é extraordinariamente fluida; poder-se-ia dizer, quando se quisesse introduzir uma diferenciação de algum modo praticável, que o princípio está já num grau maior de concretização do que o valor: ao contrário deste, ele já compreende a bipartição, característica da proposição de Direito em previsão e consequiência jurídica. Assim, por exemplo, por detrás do princípio da auto-determinação negocial, está o valor da liberdade; mas enquanto este só por si, ainda não compreende qualquer indicação sobre as consequiências jurídicas daí derivadas, aquele já exprime algo de relativamente concreto e designadamente que a proteção da liberdade é garantida através da legitimidade, conferida a cada um, para a regulação autônoma e privada das suas relações com os outros" (Claus-Wilhelm Canaris, Pensamento sistemático e conceito de sistema na ciência do direito, cit., p. 86-87).

266 No original: "Los principios jurídicos son los pensamientos directores de una regulación jurídica existente o posible" (Karl Larenz, Derecho justo, Fundamentos de etica jurídica, cit., p. 32).

267 Francisco Amaral, Direito civil: introdução, 7. ed., cit., p. 62-62. 
a igualdade dos cônjuges, a função social da propriedade ou a função social do contrato. $^{268}$

As regras, por sua vez, contêm determinações exigindo que seja feito exatamente aquilo que ordenam, o que demonstra a amplitude e generalidade dos princípios, se confrontados com as regras, mas, especialmente, as suas distintas orientações.

Dessa forma, as regras consistem em uma exigência prescrita de forma imperativa pela norma, que será ou não cumprida. Diante de duas regras em conflito, que não possa ser eliminado por uma cláusula de exceção, uma delas deverá ser declarada inválida. Isso significa dizer que as regras devem se realizar por completo, se válidas. Por outro lado, se dois princípios entrarem em colisão, um deverá prevalecer sobre o outro, o que será alcançado através do sopesamento, sem que isso signifique que um deles deva ser declarado inválido. ${ }^{269}$

Como se vê, um sistema não pode prescindir de suas regras nem de princípios que representem a sua base axiológica, o que torna imperiosa a existência de mecanismos que possibilitem a sua coexistência em busca da harmonia sistêmica. ${ }^{270}$

Nesse sentido, deve-se ressalvar a forma com que os princípios se concretizam, e a sua intrínseca relação com as categorias formadas pelos valores, pelas cláusulas gerais e pelos padrões.

268 Francisco Amaral, Direito civil: introdução, 7. ed., cit., p. 65.

269 Robert Alexy, Teoria dos direitos fundamentais, cit., p. 92-94.

270 "A aspiração de um extremado racionalismo, que pretendesse deduzir exclusivamente de puros princípios a concreta multiplicidade das regras de direito seria indubitavelmente rechaçada por qualquer jurista; mas igualmente errônea seria a pretensão de um exagerado empirismo que presumisse construir a posteriori, utilizando as normas particulares, os princípios que constituem sua premissa e sua base." No original: "La aspiración de un extremado racionalismo, que pretendiera deducir exclusivamente de puros principios la concreta multiplicidad de las reglas de derecho, sería indudablemente rechazada por cualquier jurista; pero igualmente errónea sería la pretensión de un exagerado empirismo que presumiera de construir a posteriori, utilizando las normas particulares, los principios que constituyen su premisa y su base" (Giorgio Del Vecchio, Los principios generales del derecho, 3. ed., tradução de Juan Ossorio Morales, Barcelona: Bosch, 1971, p. 66). 
Sobre o tema, ensina Rosa Maria de Andrade Nery, afirmando que os princípios não consistem em regras gerais passíveis de serem invocadas, imediatamente, em situações muito genéricas, para solução de algum caso particular, eis que, para cumprirem o seu papel, devem ser, antes de tudo, concretizados em vários graus. Por essa razão, outros fatores merecem o interesse de análise do cientista do direito, tais como os aspectos metajurídicos e históricos da fenomenologia jurídica, os quais, no âmbito das relações de direito privado, predispõem os seus tradicionais elementos (os sujeitos, os bens e os atos) a um novo enfrentamento, cercado de categorias denominadas de valores, princípios, cláusulas gerais e padrões. ${ }^{271}$

Partindo da lição de Giorgio Oppo, ressalva a desembargadora paulista que as categorias formadas pelos valores, princípios, cláusulas gerais e padrões contêm uma ligação funcional entre elas, além de uma hierárquica instrumentalidade entre si, que pode ser vista a partir dos valores funcionando como idealidades civis que inspiram a ordem jurídica, enquanto os princípios constituem a assunção desses valores em forma de preceitos e as cláusulas gerais consubstanciam a identificação de critérios preliminares de conduta, ao passo que os padrões valorativos consistem na medida social da aplicação daqueles critérios. Assim, os valores fundamentais possuem prioridade absoluta, bem como os princípios que os refletem, obrigando os juristas a adequar sua avaliação a elas. ${ }^{272}$

Deste modo, para que se torne possível encontrar a solução almejada através dessa tese, faz-se imperioso alicerçar o objeto do trabalho na base valorativa do ordenamento jurídico brasileiro, bem como em seus princípios, cláusulas gerais, regras e padrões. Porém, a análise deve, sempre, partir do sistema, a fim de "traduzir e realizar a adequação valorativa e a unidade interior da ordem jurídica". ${ }^{273}$

\footnotetext{
271 Rosa Maria de Andrade Nery, Introdução ao pensamento jurídico e à teoria geral do direito privado, São Paulo: RT, 2008, p. 231.

272 Idem, ibidem, p. 231.

273 Claus-Wilhelm Canaris, Pensamento sistemático e conceito de sistema na ciência do direito, cit., p. 23.
} 
Outrossim, é necessário ressalvar que o ordenamento jurídico brasileiro está assentado em um sistema aberto, eis que marcado pela incompletude e, por essa razão, pela necessária criação de mecanismos capazes de permitir a sua transformação a partir das demandas exigidas pela evolução da vida social.

Trata-se de um sistema dinâmico, capaz de se amoldar à natureza históricocultural do direito, seja por meio de um contínuo desenvolvimento do entendimento jurisprudencial, seja pela intervenção do próprio legislador.

Isso porque a convivência humana, fonte geradora de conflitos, impõe ao sistema um modelo que se transforme e acolha as constantes renovações dos problemas decorrentes do trato social, em uma dinâmica, contínua e rica mutação, que não prejudica a sua ordenação sistemática.

De fato, a estrutura do sistema não deve se fundar no apego extremado e incondicional às regras, característico dos sistemas fechados, amparados em uma pretensão de completude, em um positivismo exagerado, incapaz de responder a questões como aquelas referentes às contradições de princípios, à existência das chamadas normas injustas, à ocorrência de lacunas legais ou à realização dos conceitos indeterminados.

Um sistema aberto aceita a contribuição do jurista na construção de uma ordem jurídica que se encontre em consonância com a evolução social, além de permitir ao juiz que preencha o conteúdo valorativo dos conceitos indeterminados e das cláusulas gerais de acordo com os fundamentos axiológicos de seu tempo.

Como mecanismos para essa transformação do sistema aberto apresentamse, essencialmente, os princípios gerais do direito, os conceitos legais indeterminados, os conceitos determinados pela função e as cláusulas gerais. Na feliz definição de Rosa Maria de Andrade Nery os princípios gerais do direito correspondem a regras de conduta que não estão positivadas no sistema normativo e carecem de concreção, para nortear o juiz na interpretação da norma, do ato ou negócio jurídico. Os conceitos legais 
indeterminados, por sua vez, consistem em palavras ou expressões de conteúdo e extensão extremamente vagos, inçadas na lei, que lhes enuncia o conceito e fornece as consequências deles advindas. Os conceitos determinados pela função correspondem ao resultado da valoração efetivada pelo juiz dos conceitos legais indeterminados, que os torna concretos, determinando-os pela função. Já as cláusulas gerais consistem em normas orientadoras, dirigidas precipuamente ao juiz, sob forma de diretrizes, vinculando o julgador ao mesmo tempo em que lhe dão liberdade para decidir. Possuem caráter genérico e abstrato, cujos valores demandam o preenchimento de seu conteúdo por parte do juiz, decorrente de sua própria formulação legal que possui natureza de diretriz. $^{274}$

Entretanto, não se deve confundir as cláusulas gerais com os denominados standards, pois as primeiras consistem em normas jurídicas abertas que permitem a subsunção dos mais distintos comportamentos, constituindo normas dúcteis e flexíveis. Seu conteúdo surgirá, apenas, quando da aplicação dessa hipótese aberta ao caso concreto. Aqueles, por seu turno, podem aparecer como conteúdo da cláusula geral, como conceito flexível do princípio e ainda podem se igualar aos conceitos legais indeterminados, posto tratar-se de uma "norma em branco". 275

Em nosso Código Civil estão dispostos diversos conceitos legais indeterminados, tais como a ordem pública e os bons costumes, previstas em seu art.

274 Rosa Maria de Andrade Nery, Introdução ao pensamento jurídico e à teoria geral do direito privado, cit., p. 210-212.

275 Teresa Ancona Lopez, Princípio da precaução e evolução da responsabilidade civil, cit., p. 83. 
$122,{ }^{276}$ o caso de urgência do art. $251,{ }^{277}$ parágrafo único, ou a justa causa disposta no art. $1.848 .^{278}$

O mesmo acontece com as cláusulas gerais, como, por exemplo, a função social do contrato disposta no art. $421,{ }^{279}$ a boa-fé objetiva e a probidade do art. $422^{280}$ ou a função social da propriedade prevista pelo art. $1.228, \S 1 .{ }^{\circ}{ }^{281}$

Dessa forma, é possível verificar que nosso ordenamento está alicerçado em um sistema aberto, capaz de se amoldar às transformações da vida social, preservandose sua ordem de valores fundamentais.

Neste contexto de proteção do arcabouço valorativo de nosso sistema, há que se salientar que o ordenamento pátrio apresenta como valor-fonte a pessoa humana e sua dignidade, "pedra de toque da aferição da legitimidade da ordem jurídica positiva". ${ }^{282}$

276 “Art. 122. São lícitas, em geral, todas as condições não contrárias à lei, à ordem pública ou aos bons costumes; entre as condições defesas se incluem as que privarem de todo efeito o negócio jurídico, ou o sujeitarem ao puro arbítrio de uma das partes."

277 "Art. 251. Praticado pelo devedor o ato, a cuja abstenção se obrigara, o credor pode exigir dele que o desfaça, sob pena de se desfazer à sua custa, ressarcindo o culpado perdas e danos. Parágrafo único. Em caso de urgência, poderá o credor desfazer ou mandar desfazer, independentemente de autorização judicial, sem prejuízo do ressarcimento devido."

278 "Art. 1.848. Salvo se houver justa causa, declarada no testamento, não pode o testador estabelecer cláusula de inalienabilidade, impenhorabilidade, e de incomunicabilidade, sobre os bens da legítima. $\S 1 .^{\circ}$ Não é permitido ao testador estabelecer a conversão dos bens da legítima em outros de espécie diversa. $\S 2 .^{\circ}$ Mediante autorização judicial e havendo justa causa, podem ser alienados os bens gravados, convertendo-se o produto em outros bens, que ficarão sub-rogados nos ônus dos primeiros."

279 "Art. 421. A liberdade de contratar será exercida em razão e nos limites da função social do contrato."

280 “Art. 422. Os contratantes são obrigados a guardar, assim na conclusão do contrato, como em sua execução, os princípios de probidade e boa-fé."

281 "Art. 1.228. O proprietário tem a faculdade de usar, gozar e dispor da coisa, e o direito de reavê-la do poder de quem quer que injustamente a possua ou detenha. $\S 1$ o $O$ direito de propriedade deve ser exercido em consonância com as suas finalidades econômicas e sociais e de modo que sejam preservados, de conformidade com o estabelecido em lei especial, a flora, a fauna, as belezas naturais, o equilíbrio ecológico e o patrimônio histórico e artístico, bem como evitada a poluição do ar e das águas."

282 Miguel Reale, Nova fase do direito moderno, cit., p. 63. 
Partindo-se dessa premissa, deve-se ressaltar que os princípios da dignidade humana, da solidariedade social e da justiça distributiva constituem objetivos fundamentais de nosso ordenamento e a base axiológica sobre a qual está assentado todo o sistema jurídico brasileiro.

Essa é a base valorativa fundamental de nosso sistema e que servirá como norte para a conclusão desta tese, consoante restará demonstrado no item seguinte.

\section{a) A confiança como um dos valores fundantes da responsabilidade civil no sistema jurídico brasileiro. Fundamentos de uma responsabilidade pela confiança}

Feita a distinção entre princípios e regras e a análise acerca dos mecanismos que tornam possível a abertura de nosso sistema, viabiliza-se que sejam alcançadas conclusões concretas para nosso trabalho, posto existirem dispositivos legais que impõem o dever de informar, mas também situações intersubjetivas em que inexiste um dever legal de informação, embora constituam fontes de dano em potencial.

Nessas hipóteses, são insuficientes as alegações genéricas acerca de afrontas a princípios constitucionais ou fundadas em suposta violação à boa-fé objetiva, como se fossem solução para todos os litígios decorrentes das relações privadas.

$\mathrm{Na}$ verdade, o objetivo da presente tese consiste no levantamento de alguns critérios para sopesar os princípios e as regras de nosso ordenamento, a fim de apresentar soluções para a questão atinente à responsabilidade pelas informações, conselhos e recomendações, afastando-se da confortável conclusão retórica em que se afirma que tudo se resolve pela dignidade humana e pela boa-fé objetiva.

Neste diapasão, já restou demonstrado que a República Federativa do Brasil apresenta como objetivos precípuos a construção de uma ordem jurídica justa e solidária, impondo deveres primários que devem ser observados por todos aqueles que estejam subordinados ao nosso ordenamento. 
Por conseguinte, a pessoa, sujeito de direitos e titular de relações jurídicas reguladas pelas normas do ordenamento brasileiro, deve agir de acordo com o nosso sistema, em observância aos deveres impostos pela ordem jurídica.

No que se refere particularmente ao nosso tema, deve-se ressaltar que o sistema jurídico pátrio apresenta como fonte da responsabilidade civil a violação de um dever jurídico originário, que dá origem ao dever jurídico secundário de reparar os danos daí decorrentes.

Isso significa dizer que a responsabilidade civil demanda necessariamente a violação de um dever jurídico e a ocorrência de dano. Deste modo, "toda conduta humana que, violando dever jurídico originário cause prejuízo a outrem é fonte geradora de responsabilidade civil". 283

Outrossim, vale ressalvar que, a partir do advento da Constituição Federal de 1988, ampliaram-se sobremaneira as fronteiras da responsabilidade civil na ordem jurídica brasileira, como decorrência necessária da proteção da pessoa humana, bem como da preservação da solidariedade social e da busca por uma justiça distributiva.

Assim, verifica-se no texto constitucional, v.g., o princípio da indenizabilidade do dano moral em caso de sua violação, consoante se infere da leitura dos incs. V e X do citado art. 5. ${ }^{\circ}$.

Sobre o tema, ressalva Carlos Alberto Bittar que, "pelo princípio da indenizabilidade do dano moral, protegem-se os valores éticos em toda a sua extensão, com reflexos positivos na teoria da responsabilidade civil, no plano dos direitos da personalidade, no dos direitos autorais e em outros em que interfira". ${ }^{284}$

Mas não é só. Eis que a Constituição Federal de 1988 também instituiu a objetivação da responsabilidade civil, através da adoção de inúmeras regras que

\footnotetext{
283 Sérgio Cavalieri Filho, Programa de responsabilidade civil, cit., p. 2.

284 Carlos Alberto Bittar, O direito civil na Constituição de 1988, cit., p. 27.
} 
representam a diretriz da responsabilidade sem culpa, consagrando-se, por conseguinte, a teoria do risco, como é o caso da responsabilidade do Estado ou daquela decorrente de atividades nucleares. ${ }^{285}$

Dessa forma, demonstra-se de forma inequívoca a inserção de normas de cunho privado no texto constitucional brasileiro, especialmente no tocante à responsabilidade civil, objeto do presente trabalho.

Surge então a necessidade de se proceder a uma nova leitura do direito privado, partindo-se da base axiológica insculpida pela Constituição Federal de 1988 e que permeia de forma indelével o âmbito das relações entre particulares. ${ }^{286}$

A inobservância desses preceitos e a consequente violação aos deveres impostos pelas diretrizes fundamentais de nossa Carta Magna constituem fonte primeira da responsabilidade civil.

O mesmo se diga da violação aos demais deveres insertos em nosso direito positivo, que, fonte potencial de danos, gera o dever subsidiário de repará-los.

285 Antonio Junqueira de Azevedo ressalta que a sede constitucional do dever de segurança se encontra no art. 5. ${ }^{\circ}$ da Constituição de 1988 , como decorrência do princípio da dignidade da pessoa humana, no preceito relacionado ao respeito à integridade física e psíquica, afirmando que: "A obrigação de segurança existe sempre; os danos à pessoa devem ser indenizados. É importante dizer, em matéria de danos à pessoa, a regra é hoje a responsabilidade objetiva. A responsabilidade subjetiva, nesse campo, é a exceção. A responsabilidade objetiva, na obrigação de segurança, surge agora diretamente da Constituição (não é da lei ou da jurisprudência); somente haverá responsabilidade subjetiva quando houver lei expressa (p. ex., na responsabilidade médica - na qual, assim mesmo, há inversão do ônus da prova, porque a prova deve ser feita por quem tem melhores condições para fazê-la). A admissão da responsabilidade subjetiva como exceção à responsabilidade objetiva constitucional é admissível, porque os preceitos decorrentes dos princípios jurídicos não são absolutos" (Caracterização jurídica da dignidade da pessoa humana, cit., p. 3).

286 Sobre o tema, Luiz Edson Fachin comenta o desafio representado pela nova leitura do direito privado sob a égide de um sistema de normas constitucionais abertas e de princípios fundamentais que se estendem a todos os ramos de nosso ordenamento: "Não obstante, o desafio é apreender extrasistematicamente o sentido da possibilidade da constitucionalização como ação permanente, viabilizada na força criativa dos fatos sociais que se projetam para o Direito, na doutrina, na legislação e na jurisprudência, por meio da qual os significados se constroem e refundam de modo incessante, sem juízos apriorísticos de exclusão. Nessa toada, emerge o mais relevante desses horizontes que é a dimensão prospectiva dessa travessia. O compromisso se firma com essa constante travessia que capta os sentidos histórico-culturais dos Códigos e reescreve, por intermédio da ressignificação dessas balizas lingüísticas, os limites e as possibilidades emancipatórias do próprio Direito" (Questões de direito civil contemporâneo, Rio de Janeiro: Renovar, 2008, p. 18). 
Essa a razão de ser da responsabilidade civil, que decorre de qualquer violação aos deveres impostos por nosso ordenamento capaz de causar alguma espécie de dano, ainda que eminentemente moral, transformando-se em mecanismo que torne possível o exercício pleno da dignidade humana.

Nesse sentido, ressalva Teresa Ancona Lopez que a responsabilidade civil é hoje "o Direito de Danos", eis que, em sua evolução, colocou a vítima dos danos em seu centro, tornando imperioso repará-la, "custe o que custar, seja quem for o seu ofensor". 287

Como se vê, a responsabilidade civil é una e surge da ideia de que aquele que viola direito alheio e cause dano a outrem tem o dever de promover a sua reparação.

Por conseguinte, não nos parece correta a assertiva no sentido de existirem duas espécies de responsabilidade civil, uma decorrente da violação do contrato, possuindo uma base eminentemente negocial, e a outra de natureza extracontratual, fundada em um alicerce delitual, como dois compartimentos estanques e expressamente delimitados por fronteiras claras e inequívocas.

Isso porque, consoante já dito, a responsabilidade civil decorre da violação de um dever primário imposto pela ordem jurídica, que, causando dano a outrem, dá origem a um dever subsidiário de repará-lo, independentemente de sua fonte estar fundada em um contrato, no delito ou em qualquer outro gênero.

Afirmar que existem duas espécies distintas de responsabilidade, uma dita contratual e outra denominada extracontratual, representa, em nossa opinião, uma impropriedade, posto que essa dicotomia não se refere a "espécies distintas de responsabilidade", mas apenas à dualidade de regimes pré-ordenados por um determinado sistema jurídico.

287 Teresa Ancona Lopez, Princípio da precaução e evolução da responsabilidade civil, cit., p. 65. 
De fato, a existência de regimes distintos de responsabilidade representa uma opção do legislador para ordenar um determinado sistema jurídico, estabelecendo diretrizes para a reparação dos danos decorrentes da violação dos chamados deveres primários.

Conceituar a responsabilidade civil através dos regimes impostos pelo sistema, limitando-a a eles, significa reverter de maneira não apropriada a base da pesquisa e estudar o instituto não por sua natureza, mas de acordo com o regime escolhido pelo legislador em momento e local determinados.

Dessa forma, eventual alteração na opção legislativa faria com que toda a teoria fundada eminentemente nos regimes legais anteriores ruísse, posto que não alicerçada no fundamento da responsabilidade.

Por essa razão, a construção de uma teoria para a responsabilidade civil deve partir de seus fundamentos essenciais e não de regimes impostos pelo legislador em tempo e espaço determinados.

Não se deve, por óbvio, descurar do sistema jurídico que é objeto da análise, sob pena de chegar a conclusões completamente afastadas da realidade. No entanto, partindo-se dos fundamentos da responsabilidade é possível chegar à discussão acerca da escolha dos regimes impostos pelo legislador e, até mesmo, verificar a existência de outras possibilidades previstas pelo ordenamento.

Neste sentido, ensina Carneiro da Frada que "o fundamento da responsabilidade corresponde ao critério de validade (jurídica) da obrigação de indenizar". 288

Ora, a responsabilidade civil no Brasil não se limita à dicotomia "responsabilidade contratual - responsabilidade extracontratual", o que pode ser comprovado pela opção efetuada pelo legislador consumerista ao afastar-se da secular

288 Manuel Antonio de Castro Portugal Carneiro da Frada, Teoria da confiança e responsabilidade civil, cit., p. 351. 
discussão acerca da origem decorrente do contrato ou do delito e optar por um regime diferenciado de responsabilidade em que se impõe um dever geral de segurança, capaz de tutelar inclusive as vítimas de acidentes de consumo que não tenham sequer celebrado um contrato com o fornecedor de produtos ou de serviços, nos termos do art. 17 do Código de Defesa do Consumidor.

Deste modo, pode-se afirmar que nosso sistema apresenta como diretriz fundamental da responsabilidade civil a reparação de danos decorrentes da violação de um dever primário através dos mais distintos regimes escolhidos pelo legislador, o que corresponde ao critério jurídico genérico da obrigação de indenizar, fundamento da responsabilidade.

Nesse contexto, e em especial no que concerne ao tema de nossa tese, faz-se imperioso ressaltar a existência de um dever geral de conduta ética, proba e leal na ordem jurídica brasileira, que não se limita apenas às atividades negociais, mas permeiase por todo o ordenamento em razão da base valorativa inserta em nossa Magna Carta e dos objetivos fundamentais da República.

Como consequência, a violação a esse dever de conduta pautado pela honestidade, lealdade e eticidade constitui fonte de responsabilidade civil, desde que existam danos, independentemente de sua origem fundar-se em um negócio jurídico ou em um ato ilícito, eis que violada a relação de confiança indispensável ao trato social e que se concretiza em nosso ordenamento através do princípio da boa-fé objetiva.

Afirmar que a boa-fé objetiva está limitada aos atos negociais significa reduzir sobremaneira a sua amplitude, para concluir que as relações intersubjetivas alheias a um contrato não estariam subordinadas a um dever geral de conduta pautado pela ética, honestidade e lealdade.

Ora, a extensão da área de atuação da boa-fé não se restringe aos limites do contrato nem às situações extracontratuais, mas atinge todas as relações intersubjetivas de maneira ampla e difusa, disseminando-se através do valor fundamental 
consubstanciado pela confiança, essencial para a estabilização da complexidade da vida em sociedade. ${ }^{289}$

Em nossa opinião, a limitação da amplitude da boa-fé objetiva aos atos negociais contraria frontalmente a base de valores que hoje impera em nosso ordenamento, além de autorizar, de maneira temerária, que uma gama incomensurável de relações entre particulares possa se pautar por atitudes contrárias à ética, à boa-fé e aos bons costumes.

Isso porque as relações intersubjetivas não se resumem aos contratos e apresentam uma ampla diversidade, catapultada pelos avanços tecnológicos característicos da sociedade atual e fonte potencial de danos. Esse relacionamento entre sujeitos de direito deve ser pautado pela ordem de valores impostos pelas diversas normas que integram o nosso ordenamento.

Neste diapasão, insta salientar que a base axiológica do Código Civil de 2002, em consonância com a ordem constitucional, encontra-se alicerçada na eticidade e na socialidade.

Sobre o tema, ressalva Miguel Reale que, uma vez estabelecidos os dois princípios como diretrizes fundamentais do Código Civil, a fruição dos próprios direitos não pode mais ser considerada sem limites, posto que os direitos devem ser exercidos

289 “O mundo está se dissipando em uma complexidade incontrolável; tanto que a qualquer tempo as pessoas podem eleger livremente entre ações muito diferentes. Sem embargo tenho que atuar aqui e agora. Existe somente um breve momento em que é possível ver o que os outros fazem e adaptar-me conscientemente a isto. Nesse preciso momento somente algo da complexidade se pode considerar e processar, o que faz com que seja possível ganhar apenas um pouco de racionalidade. (...) Se confio no fato de que outros estão atuando - ou não o estão fazendo - em harmonia comigo, posso conseguir meus próprios interesses mais racionalmente, conduzir mais sereno no tráfego." No original: "El mundo se está malgastando en una complejidad incontrolable; tanto que en cualquier tiempo dado las personas pueden elegir libremente entre acciones muy diferentes. Sin embargo, tengo que actuar aquí y ahora. Existe solamente un breve momento del tiempo en que me es posible ver lo que otros hacen, y adaptarme conscientemente a ello. (...) Si confío en el hecho de que otros están actuando - o no lo están haciendo - en armonía conmigo, puedo conseguir mis propios intereses más racionalmente, conducir más sereno en el tráfico" (Niklas Luhmann, Confianza, tradução de Amada Flores, Barcelona: Antrophos; México: Universidad Iberoamericana, 1996, p. 39-40). 
em benefício da pessoa, mas respeitados os fins ético-sociais da comunidade a que pertence o seu titular. ${ }^{290}$

Além disso, o princípio da socialidade representa o triunfo dos valores coletivos sobre os individuais, sem perder o valor fundante da pessoa humana, ao passo que a eticidade torna possível o recurso a critérios ético-jurídicos que permitam chegar à "concreção jurídica", conferindo-se maior poder ao juiz a fim de se encontrar a solução mais justa ou equitativa. ${ }^{291}$

Em termos de responsabilidade civil essa diretriz consiste em não causar dano a outrem, adotando-se um padrão de conduta ético essencial para a vida em sociedade, nos seus mais diferentes matizes, independentemente de sua origem estar pautada ou não por um negócio jurídico.

De fato, esse padrão de conduta estende-se por todos os ramos do direito privado em decorrência da base valorativa de nosso ordenamento. Além disso, diversos são os dispositivos do Código Civil a impor referido padrão e que não se limitam à disciplina dos atos negociais, tais como, por exemplo, a proibição da prática de atos meramente emulativos que não tragam ao proprietário nenhuma utilidade ou comodidade quando do exercício de seu direito de propriedade (art. 1.228, § 2. $\left.{ }^{\circ}\right)^{292}$ ou o dever de lealdade dos companheiros (art. 1.724). ${ }^{293}$

Por conseguinte, o que se pretende demonstrar é a existência de um determinado padrão ético de conduta ${ }^{294}$ imposto a todos os sujeitos que atuem em nosso

290 Miguel Reale, Estudos preliminares do Código Civil, São Paulo: RT, 2006, p. 36.

291 Miguel Reale, O projeto do novo Código Civil, 2. ed., São Paulo: Saraiva, 1999, p. 7-8.

292 “Art. 1.228. O proprietário tem a faculdade de usar, gozar e dispor da coisa, e o direito de reavê-la do poder de quem quer que injustamente a possua ou detenha. $\S 1 .^{\circ} \mathrm{O}$ direito de propriedade deve ser exercido em consonância com as suas finalidades econômicas e sociais e de modo que sejam preservados, de conformidade com o estabelecido em lei especial, a flora, a fauna, as belezas naturais, o equilíbrio ecológico e o patrimônio histórico e artístico, bem como evitada a poluição do ar e das águas. $§ 2 .^{\circ}$ São defesos os atos que não trazem ao proprietário qualquer comodidade, ou utilidade, e sejam animados pela intenção de prejudicar outrem."

293 “Art. 1.724. As relações pessoais entre os companheiros obedecerão aos deveres de lealdade, respeito e assistência, e de guarda, sustento e educação dos filhos.”

294 Ao comentar a emergente relevância da responsabilidade civil no âmbito da ciência jurídica Paulo César Manduca assim observa: "Como o Direito é uma ciência intrinsecamente ligada à realidade, 
ordenamento que, ao ser violado, causando dano a outrem, gera o dever de repará-lo, estando ou não sob a égide do contrato.

Assim, nosso sistema dá guarida a uma responsabilidade civil decorrente da quebra do dever de conduta ética, proba e leal, ou seja, da ruptura do valor fundamental da confiança, essencial às relações intersubjetivas.

É exatamente essa a tese que se defende em nosso trabalho, consistente na existência de uma responsabilidade pela confiança, já amparada em nosso ordenamento e que decorre da violação do dever primário de conduta ética, impondo o dever de reparar os danos por ela causados.

Não se trata de uma terceira via da responsabilidade civil - que seria somada à responsabilidade contratual e à extracontratual -, mas de um valor fundamental de nosso sistema, fonte de um dever de conduta que se permeia por todas as relações de direito privado e que, uma vez violado, gera o dever subsidiário de reparar os danos decorrentes dessa violação, a fim de evitar que suas vítimas permaneçam irressarcidas.

Nestes casos, a fonte da obrigação de reparar os danos consiste na valoração jurídica da confiança que gera um dever de conduta decorrente de uma imputação normativa, entendendo-se como norma jurídica "um modelo de comportamento ou de organização que representa valores ou fins a atingir". 295

pode-se completar essa idéia mostrando a importância de tal instituto para a realização da cidadania moderna, uma vez que a Responsabilidade insere-se fortemente na corrida por um padrão ético que se contraponha ao despotismo e à corrupção tanto na esfera do Estado quanto nas demais esferas da vida social. A Responsabilidade Civil, assim, é entendida como um mecanismo de imposição de um padrão ético ao comportamento dos atores sociais em uma esfera na qual as leis ou os outros institutos consagrados não alcançam, uma vez que os problemas em questão sobre o qual se aplica o instituto da responsabilidade civil são direitos ou noção de direitos que geralmente estão na fronteira do novo no tocante às relações sociais" (Responsabilidade civil e responsabilidade social: a construção da sociabilidade no Brasil de hoje e de amanhã, in: José Luiz Gavião de Almeida [Org.], Temas atuais de responsabilidade civil, São Paulo: Atlas, 2007, p. 105).

295 Francisco Amaral, Direito civil: introdução, 7. ed., cit., p. 99. 
Ora, o ordenamento jurídico brasileiro prescreve um padrão de conduta ético, que representa o modelo de comportamento e os valores que pretende atingir, consubstanciando-se a imputação normativa que prescreve um dever ser pautado pelo ethos da confiança. A violação desse dever acarreta a consequente obrigação de reparar os danos decorrentes da conduta contrária à valoração jurídica da confiança.

Sobre o tema, é importante salientar que os princípios são normas jurídicas $^{296}$ e a sua violação pode dar origem à reparação de danos, o que é especialmente importante para a fundamentação de uma responsabilidade pela confiança, eis que sua concreção se verifica através do princípio da boa-fé objetiva.

Assim, como postulado jurídico dessa obrigação de reparar os danos, encontra-se a ampla proteção do ethos da confiança, enquanto valor jurídico fundamental de nosso ordenamento, fonte de um dever de conduta decorrente de imputação normativa expressa de nosso sistema, seja através de princípios, seja através de regras dispostas na ordem jurídica.

Com efeito, existe um dever de conduta pautado pelo valor fundamental da confiança e que possui como fundamento a dignidade humana e o solidarismo social, objetivos da República, impostos a todos aqueles que atuem em nosso sistema.

Esse ethos da confiança significa resgatar as disposições morais das relações humanas, estimulando o comportamento ético e probo, a lealdade de tratamento e o respeito à esfera jurídica de outrem, para prevenir que as pessoas sejam vítimas de danos. Assim a antijuridicidade se caracteriza pela violação a esse dever de conduta.

Com se vê, a confiança apresenta destacada importância para o presente estudo, eis que a troca de informações se encontra firmada em uma relação de fidúcia

\footnotetext{
296 "Porque os princípios, apesar de sua generalidade e indeterminação linguística, atendem aos pressupostos formais e materiais exigidos para a caracterização das normas jurídicas, parece indiscutível que não se lhes pode negar seu caráter normativo. Além disso, é preciso ter em mente que a grande maioria das normas integrantes dos ordenamentos jurídicos são tão-somente especificações dos princípios que os norteiam; vale dizer: a generalidade do conteúdo normativo do princípio é minudenciada por meio de normas específicas" (Marcos Bernardes de Mello, Teoria do fato jurídico: plano da existência, 15. ed., São Paulo: Saraiva, 2008, p. 23).
} 
entre sujeitos de direito, assim como a expectativa criada por quem recebe um conselho ou uma recomendação pode tornar-se merecedora de tutela jurídica, especialmente se a sua infirmação resultar em dano a ser imputado àquele que aconselhou ou recomendou.

Não se trata, todavia, de tema alheio a controvérsias, nem de fácil sistematização, posto a indeterminação de seu conceito e o seu variegado significado aliados à ausência de uma definição legal a seu respeito - contribuírem para tornar o campo de investigação em terreno fluido e tormentoso. ${ }^{297}$

De fato, em uma sociedade altamente complexa e marcada pela impessoalidade, inúmeras são as relações intersubjetivas calcadas na confiança, transformando-a em elemento indissociável das relações entre sujeitos, seja em virtude das expectativas originadas pelo comportamento de outrem, seja em virtude das representações que a pessoa tenha por efetivas.

As relações humanas demandam necessariamente a confiança para que possam se desenvolver, firmando os seus vínculos, formando e mantendo condições para o convívio social, para o exercício das práticas comerciais e da consequente circulação de riquezas, o que a torna um elemento central para a vida em sociedade. ${ }^{298}$

297 “A confiança não é em direito, um tema fácil. As dificuldades que ela coloca transcendem em muito a necessidade de delimitação do seu âmbito, já de si problemática. Não existe nenhuma definição legal de confiança a que possa socorrer-se e escasseiam referências normativas explícitas a propósito. O seu conceito apresenta-se fortemente indeterminado pela pluralidade ou vaguidade de empregos comuns que alberga, tornando difícil traçar com ele as fronteiras de uma investigação jurídica. Tanto mais que transporta uma certa ambigüidade de princípio por se poder referir, tanto à causa, como aos efeitos de uma regulação jurídica. É a falta de consciência dessa realidade que está na raiz de uma certa evanescência da confiança no discurso jurídico e se apresenta - antecipe-se responsável pelas dificuldades que se não logrou ainda hoje desembaraçar-se a reflexão dogmática a seu respeito" (Manuel Antonio de Castro Portugal Carneiro da Frada, Teoria da confiança e responsabilidade civil, cit., p. 17).

298 Na clássica observação de Niklas Luhmann, "o homem pode, em certos aspectos, decidir se outorga ou não confiança. Porém, uma ausência completa de confiança o impediria sequer de levantar-se em uma manhã. Seria vítima de um medo indefinido e de temores paralisantes. Nem sequer poderia formular uma desconfiança definida e torná-la base de medidas preventivas, porque isso implicaria confiança em outras direções. Qualquer coisa e tudo seria possível. Uma confrontação abrupta com a complexidade do mundo, em seu grau máximo, é mais do que suporta o ser humano". No original: "Por supuesto que en muchas situaciones, el hombre puede en ciertos aspectos decidir si otorga confianza o no. Pero una completa ausencia de confianza le impediría incluso levantarse en la mañana. Sería víctima de un sentido vago de miedo y temores paralizantes. Incluso no sería capaz de formular una desconfianza definitiva y hacer de ello un fundamento para medidas preventivas, ya que esto presupondría confianza en otras direcciones. Cualquier cosa y todo sería posible. Tal 
Dos relacionamentos sociais mais simples até as estruturas contratuais mais complexas, a atuação dos sujeitos funda-se em uma relação de confiança, enquanto base fundamental para o seu desenvolvimento. O comportamento das pessoas está pautado nesse alicerce, em que se criam expectativas e se operam as formas de cooperação humana.

Por outro lado, o alto grau de complexidade característico das atuais relações intersubjetivas, catapultadas pelo outrora inimaginável avanço da tecnologia capaz de permitir a conexão de sujeitos nos mais distintos rincões do planeta, cria novos níveis de confiança, alteando a importância de se proceder à sua tutela.

Com efeito, a quebra da fidúcia pode significar a ocorrência de danos e ser altamente nociva ao tráfego interindividual, especialmente porque os limites morais da sociedade atual parecem ser cada vez mais tênues e a desconfiança, generalizada, impondo-se ao direito promover a proteção da confiança a fim de preservar os parâmetros éticos tão caros ao desenvolvimento da vida em comunidade e do solidarismo social.

Entretanto, é certo também que a intensidade das relações pautadas na confiança é vária, o que leva a perquirir sobre os modos de se proceder à sua proteção, bem como sobre as formas pelas quais se irradia no âmbito jurídico e os diversos efeitos por ela produzidos.

No que tange ao tema da presente tese, é possível verificar que, em incontáveis ocasiões, os sujeitos depositam plena convicção nas informações apresentadas por seus interlocutores ou creem firmemente nos conselhos e nas recomendações que lhes são prestados.

Em outros casos, contudo, a expectação criada por um aconselhamento não está dissociada de certa incerteza quanto ao seu resultado nem a crença em uma recomendação demonstra-se suficientemente capaz de firmar o convencimento de seu 
destinatário. Além disso, frequentes são as situações em que informações são prestadas sem a intenção de persuadir quem as recebe.

Verifica-se, assim, que a relação de confiança apresenta diferentes matizes, além de uma destacada base moral a ressaltar a sua importância sociológica. Essa base, todavia, nem sempre interessa ao direito, posto não constituir, por vezes, uma relação merecedora de regulação jurídica. ${ }^{299}$

Por conseguinte, demonstra-se a necessidade de se discorrer acerca de seu tratamento jurídico, pois pretender encontrar fórmulas concretas de compor litígios a partir de uma base eminentemente sociológica da confiança não parece ser o caminho mais adequado.

Neste sentido, como bem adverte Menezes Cordeiro, “a importância sociológica assumida pela confiança não deve levar, no seu alcance como na sua construção, a uma transposição mecânica para o Direito". 300

De fato, notória é a importância da confiança para o desenvolvimento das relações humanas, ${ }^{301}$ a demonstrar a sua relevância para a Ciência Jurídica, que é extremamente fértil quando se trata da busca de sua sede legal, da tentativa de

299 Nesse sentido, Karl Larenz recorda o exemplo de uma pessoa que comunica a outra a sua intenção de, no dia seguinte, dar um passeio por determinado lugar e o outro responde que também irá para lá. Esse fato pode resultar em uma obrigação moral de o primeiro informar ao segundo a sua mudança de propósitos, mas o exemplo pertence a uma esfera de relações interindividuais que não requerem especial regulação jurídica - o espaço livre do direito. No original: "Recordemos el ejemplo de uno que comunica a otro que mañana se propone dar un paseo por un lugar determinado y el otro contesta que el irá allí también. Decíamos que ello puede resultar para el primero una obligación moral de informar al segundo su cambio de propósitos, pero que el ejemplo pertenece a una esfera de relaciones interindividuales que no requieren especial regulación jurídica - el espacio de lo libre de Derecho" (Derecho justo. Fundamentos de etica jurídica, cit., p. 91).

300 António Manuel da Rocha e Menezes Cordeiro, Da boa-fé objetiva no direito civil, Coimbra: Almedina, 2001, p. 1.241-1.242.

301 Nesse sentido, ressalva Karl Larenz que "a confiança forma a base indispensável de todas as relações humanas". No original: "El principio de la 'buena fe' significa que cada uno debe guardar 'fidelidad' a la palabra dada y no defraudar la confianza o abusar de ella, ya que ésta forma la base indispensable de todas las relaciones humanas (...)" (Derecho justo. Fundamentos de etica jurídica, cit., p. 91). 
construção de teorias relacionadas ao tema e dirigidas à sua tutela, ${ }^{302}$ e do estudo de situações concretas pautadas pela fidúcia e seus respectivos efeitos.

Por outro lado, a fim de ressalvar a sua importância jurídica, não se deve olvidar que o direito, enquanto sistema, atua como poderoso fator de redução da complexidade social e surge como fonte primordial da confiança, como se percebe nas relações contratuais, em que as representações que os contratantes tomam por efetivas não decorrem tanto da expectativa de um determinado comportamento da outra parte, mas, principalmente, da segurança revelada pela inserção deste pacto em canais jurídicos que apresentem um percurso predeterminado. ${ }^{303}$

Assim, releva-se a importância de tutelar juridicamente a confiança, seja atribuindo-se efeitos jurídicos equivalentes àqueles que eram objeto da representação do sujeito no momento em que praticou o ato ou celebrou o negócio, seja reparando danos decorrentes da frustração de expectativas.

Nestes casos, consoante bem ressalva Carneiro da Frada, é possível verificar uma proteção positiva e uma proteção negativa da confiança: a primeira consubstanciase na preocupação de assegurar ao sujeito a sua expectativa, enquanto na segunda negase àquele que confiou o direito de ser colocado na posição esperada em razão da representação que havia por efetiva, para, ao invés, assegurar-lhe um direito indenizatório. ${ }^{304}$

Deste modo, a tutela da confiança pode consistir na preservação da posição nela alicerçada, ou, de outra forma, em um dever de indenizar. $\mathrm{Na}$ hipótese de manutenção da situação representada pelo confiante, contudo, deve-se ressaltar o fato de que o mesmo dispositivo autorizador da tutela da confiança atua também contra a

302 Anderson Schreiber observa que "o reconhecimento da necessidade de tutela da confiança desloca a atenção do direito, que deixa de se centrar exclusivamente sobre a fonte das condutas para observar também os efeitos fáticos da sua adoção" (A proibição de comportamento contraditório. Tutela da confiança e venire contra factum proprium, cit., p. 94).

303 António Manuel da Rocha e Menezes Cordeiro, Da boa-fé objetiva no direito civil, cit., p. 1.2411.243.

304 Manuel Antonio de Castro Portugal Carneiro da Frada, Teoria da confiança e responsabilidade civil, cit., p. 42 . 
confiança daquele que é beneficiário da regulação material. Isso significa dizer, nas palavras de Menezes Cordeiro, que "a pessoa que veja o seu direito postergado a favor de quem tenha uma mera aparência, vê preterida a confiança na própria posição que, face ao sistema, apresenta sempre uma legitimidade máxima". 305

Neste mesmo sentido, assinala Carneiro da Frada que a intervenção da ordem jurídica em defesa da confiança pode resultar na "adstrição de alguém a corresponder à situação de confiança de outrem", 306 o que demonstra a necessidade de ponderar a situação concreta, através da análise aprofundada de todos os interesses envolvidos, sopesando-se as expectativas geradas pela relação intersubjetiva.

Por essa razão, há que se atentar para as tentativas de ampliação desmesurada do âmbito da tutela da confiança, a fim de evitar tendências generalizantes, que acabem por estender a sua aplicação sem nenhuma preocupação dogmática e metodológica, através de uma concepção de extensão despropositada, supostamente fundada em princípios gerais e completamente apartada do sistema. ${ }^{307}$

De fato, a proteção prioritária à vítima de danos deve ser efetivada com a devida ponderação, a fim de evitar que o excesso de proteção ao lesado seja também fonte de danos e de decisões iníquas que acabem por apenar injustamente aquele que foi considerado responsável pela reparação do dano. ${ }^{308}$

\footnotetext{
305 António Manuel da Rocha e Menezes Cordeiro, Da boa-fé objetiva no direito civil, cit., p. 1.2411.243.

306 Manuel Antonio de Castro Portugal Carneiro da Frada, Teoria da confiança e responsabilidade civil, cit., p. 42.

307 Neste sentido, Menezes Cordeiro adverte para a arraigada tendência "no modo atual de pensar o Direito, de, em permanência, procurar em metadiscursos as saídas para os temas figurativos, em vez de, numa atitude prudencial, o fazer a nível da matéria retratada, exprimindo mais uma seqüela do irrealismo metodológico" (Da boa-fé objetiva no direito civil, cit., p. 1.241).

308 "Propiciar que todos os lesados tenham seus direitos reparados é medida que merece aplausos. Mas, como costuma acontecer, a proteção excessiva a um dos integrantes da relação jurídica acaba por causar injustiça. $\mathrm{O}$ exagero com que se tem procurado a reparação dos danos, com que se tem tentado evitar que o lesado suporte a perda de seu direito, vem mostrando, de outra sorte, injustificado alcance sobre os bens de alguns que foram eleitos como responsáveis" (José Luiz Gavião de Almeida, Novos rumos da responsabilidade civil por ato ilícito, in: José Luiz Gavião de Almeida (Org.), Temas atuais de responsabilidade civil, São Paulo: Atlas, 2007, p. 63).
} 
Deste modo, impõe-se a acurada análise dos interesses em conflito no caso concreto, assim como o necessário sopesamento entre os princípios e regras de nosso sistema jurídico, em busca de soluções equilibradas, para que se possa proceder com adequação e agir de acordo com as exigências ético-jurídicas do ordenamento, logrando-se chegar à correta aplicação da responsabilidade pela confiança, sem que seus fundamentos possam constituir pressupostos para o incremento de uma desmesurada e indesejável banalização da reparação de danos.

No que tange ao tema de nossa tese, deve-se frisar que as relações intersubjetivas decorrem de um processo cognitivo em que a difusão das informações é sua pedra fundamental. Por conseguinte, a liberdade de opinião e de expressão deve ser preservada para que os diversos interlocutores possam fazer as suas escolhas.

Neste contexto, evidencia-se a importância do princípio da liberdade na formação de referido processo para permitir que os sujeitos de direito tenham a opção de seguir ou não um conselho, recomendação ou informação.

Esse princípio, contudo, pode sofrer limitações, baseadas na própria autonomia da vontade ou em razão de disposições legais expressas neste sentido. De fato, é possível que contratantes limitem a liberdade de opinião e de expressão acerca de condições do contrato por eles celebrado através de uma cláusula de sigilo. Por outro lado, é possível que o legislador infraconstitucional estabeleça sanções para um determinado prestador de serviços que se recuse a prestar informações essenciais ao exercício de sua atividade, como no caso do advogado que se recusa a informar seu cliente sobre o curso de um determinado processo.

A ponderação entre a autonomia da vontade e a expectativa gerada pela confiança será fundamental para a aferição da responsabilidade pelas informações, conselhos e recomendações, em busca de um modelo ideal no qual "cada homem possa 
alcançar o máximo de preservação de sua subjetividade com o máximo de participação aos valores comunitários. ${ }^{309}$

309 Miguel Reale, Nova fase do direito moderno, cit., p. 63. 


\section{A RESPONSABILIDADE POR INFORMAÇÕES, CONSELHOS E RECOMENDAÇÕES NO DIREITO BRASILEIRO CONTEMPORÂNEO}

\subsection{Delimitação do tema: o conceito de informação, conselho e recomendação}

\section{"Muitas coisas sabe a raposa; mas o ouriço uma grande."}

Ao discorrer sobre esse verso do poeta grego Arquíloco, Celso Lafer ${ }^{310}$ ensina que "os ouriços seriam aqueles que tudo referem a uma visão unitária e coerente, a qual opera como um projeto organizador fundamental de tudo o que pensam. Tendem, portanto, a uma perspectiva centrípeta e monista da realidade”.

As raposas, por sua vez, "seriam aqueles que se interessam por coisas várias, perseguem múltiplos fins e objetivos, cuja interconexão, ademais, não é nem óbvia e nem explícita. A tendência que aí se manifesta é centrífuga e pluralista". ${ }^{311}$

A despeito de a classificação dicotômica correr o risco da simplificação, conforme adverte o próprio Celso Lafer, ${ }^{312}$ o fato é que tanto ouriços como raposas necessitam de informações para formarem as suas respectivas convicções, sejam monistas ou pluralistas, centrípetas ou centrífugas.

No curso de seu processo cognitivo, ouriços e raposas recebem e transmitem informações, comunicam-se, seduzem-se por opiniões e ensinamentos de outrem, deixam-se persuadir por conselhos e recomendações, repelem discursos e ideias, inventam verdades, adotam o ponto de vista do outro, em um procedimento

\footnotetext{
310 Celso Lafer, Hannah Arendt. Pensamento, persuasão e poder, 2. ed., São Paulo: Paz e Terra, 2003, p. 109.

311 Idem, ibidem, p. 109.

312 Idem, p. 109.
} 
argumentativo incessante e determinante para a formação de sua personalidade e para o exercício de suas escolhas.

Essa prática argumentativa, essencial para o desenvolvimento das relações humanas, demanda a constante troca de informações em um contínuo processo de conhecimento, que se inicia com o nascimento e encontra o seu fim apenas com a morte.

Nesse processo de persuasão racional o ser humano forma as suas convicções, suas crenças ${ }^{313}$ e seus desejos, firma seus valores e princípios, assume posições refletidas e deliberadas; toma as suas decisões, escolhe os seus caminhos.

Como se vê, a pessoa humana passa por diversos procedimentos suasórios ao longo de sua existência, partindo de princípios objetivos e subjetivos, bem como de juízos de valor - motivados ou não por critérios de racionalidade -, formando assim o seu conhecimento, capaz de possibilitar a tomada de decisões a respeito de sua vida social ou particular.

Ensina Jürgen Habermas que o conhecimento resulta de três processos simultâneos, que se corrigem entre si: a) a atitude de resolver problemas diante dos riscos impostos por um ambiente complexo; b) a justificação das alegações de validade diante de argumentos opostos; e c) um aprendizado cumulativo que depende do reexame dos próprios erros. ${ }^{314}$

313 Conforme os ensinamentos de Immanuel Kant, "a crença (das Fürwahrhalten) é um fato do nosso entendimento suscetível de se estabelecer sobre princípios objetivos, mas que exige também causas subjetivas no espírito daquele que julga. Se o juízo for válido para todos, desde que pelo menos tenha razão, o seu princípio é objetivamente suficiente e a crença é denominada convicção. Se ela tem seu fundamento unicamente na natureza particular do indivíduo, ela é denominada persuasão" (Crítica da razão pura, tradução de Lucimar A. Coghi Anselmi e Fulvio Lubisco, São Paulo: Ícone, 2007, p. 515).

314 Jürgen Habermas, A ética da discussão e a questão da verdade, tradução de Marcelo Brandão Cipolla, São Paulo: Martins Fontes, 2007, p. 57. 
Partindo-se dessa premissa, ${ }^{315}$ infere-se que a formação do conhecimento envolve a manipulação de informações que permitam à pessoa, em um ambiente complexo, resolver os problemas e encontrar soluções para os riscos a que esteja sendo submetida.

Também para conseguir justificar as alegações de validade diante de argumentos opostos, é necessário que o indivíduo ou os indivíduos que participem desse processo cognitivo estejam munidos de dados e informações capazes de fazer frente à argumentação contrária.

Outrossim, ao aprender com os próprios erros, o sujeito municia-se de informações que lhes serão úteis em momentos posteriores, mas que poderão ser transmitidas a outrem, na forma de conselhos, recomendações ou advertências.

A formação dessa autoridade epistêmica do indivíduo permitirá que diga "sim" ou "não" às questões que lhe são apresentadas. ${ }^{316}$ Essa tomada de decisões em muito poderá influir no seu destino, fazendo com que tenha benefícios ou prejuízos, dependendo da forma com que foi efetuada.

De fato, a complexidade da vida moderna e a consequente redução da significância da natureza humana em detrimento da produção da atividade do labor ${ }^{317}$ empurram a pessoa humana para uma vida cotidiana cada vez mais automatizada, demandando uma gama cada vez maior de informações para que as atitudes típicas do homo faber possam ser concretizadas.

315 "Existem tipos diversos de teorias que empregam métodos diferentes e gozam de diferentes vantagens e desvantagens. Por isso, a escolha de um tipo não implica necessariamente um desprezo pelos demais" (Jürgen Habermas, A ética da discussão e a questão da verdade, cit., p. 32).

316 Jürgen Habermas, A ética da discussão e a questão da verdade, cit., p. 16.

317 Contra o que chamou de instrumentalização do mundo Hannah Arendt relata a derrota do que chamou de homo faber, cujas ações ficaram reduzidas ao princípio da utilidade, fazendo com que todas as coisas sejam vistas como matéria-prima e toda a natureza seja vista "como um imenso tecido do qual podemos cortar qualquer pedaço e tornar a coser como quisermos" (A condição humana, 10. ed., tradução de Roberto Raposo, Rio de Janeiro: Forense Universitária, 2008, p. 318). 
Deliberar, decidir, prever, optar são atitudes exigidas a cada instante da pessoa que vive nos dias de hoje, o que faz com que se encontre, em diversas ocasiões, sob a premente necessidade de fazer escolhas acerca de assuntos para os quais não possui preparo suficiente ou sequer se apresente munida de informações adequadas para tanto. $^{318}$

Como consequência, inúmeras são as ocasiões em que profissionais são consultados, formalmente ou não, para apresentarem os seus pareceres, ou apenas para darem conselhos ou recomendações sobre a melhor escolha ou decisão, a que trará maiores ganhos ou benefícios ou aquela que evitará prejuízos ou perdas consideráveis.

Nessas situações, em que existe o dever jurídico de informar, aconselhar ou recomendar, impera a confiança depositada no profissional e cria-se uma expectativa acerca de seu resultado final, que nem sempre se concretiza na prática.

Seria a frustração dessa simples expectativa capaz de gerar a responsabilidade do profissional responsável pelo conselho, recomendação ou informação? Certamente que, à míngua de maiores elementos esclarecedores, fica difícil a obtenção de uma resposta conclusiva, o que só seria possível através da perquirição sobre a existência de diversos fatores, tais como a forma pela qual a informação foi transmitida - se por meio de uma simples opinião ou por um parecer técnico fundamentado; se de uma justa expectativa decorreu um dano indenizável ou não; se houve dolo ou culpa do profissional; se é possível estabelecer uma relação de

318 Confira-se, v.g., o exemplo daqueles que se dirigem a uma instituição financeira apenas para conseguir decifrar os extratos bancários demonstrativos de seus débitos: "Execução de cédula de crédito comercial. Demonstrativo de débito. Execução de valor maior do que o constante no título. Demonstrativo incompleto. Alegação de erro na apreciação da prova. 1. Tratando-se de cédula de crédito comercial, pagável em doze prestações mensais, destinado o valor ao pagamento de dívidas anteriores, decorrentes de saldo devedor em contratos de cheque-ouro, sendo a execução em valor superior ao constante do título, o demonstrativo do débito é essencial. 2. É de comum sabença que as instituições financeiras apresentam extratos indecifráveis pelo homem médio, gerando, até mesmo, dificuldades para aqueles que habituados estão ao sistema. Se o Acórdão recorrido considera que os extratos, no caso, não são suficientes para demonstrar o débito e o especial vem fundamentado, exclusivamente, no erro do Acórdão, em apreciar esses demonstrativos, a esse fundamento amarrando todas as indicações de artigos de lei federal que teriam sido violados, torna-se forte a presença da Súmula n. 7 da Corte. 3. Recurso especial não conhecido" (REsp 234.284-SP, Min. Carlos Alberto Menezes Direito, j. 02.05.2000, DJ 26.06.2000, p. 164 - destaques do autor). 
causalidade entre o dano supostamente ocorrido e a informação defeituosa; enfim, uma miríade de fatos deveriam ser considerados em um caso concreto.

Como se vê, discutir a responsabilidade por conselhos, recomendações ou informações não representa uma fácil empreitada, pois a pluralidade de empregos comuns que podem ser aplicados a esses termos dificulta a investigação e torna imperiosa uma delimitação do âmbito de incidência do presente trabalho.

Por essa razão, torna-se necessário proceder-se à análise do significado dos vocábulos informação, conselho e recomendação, buscando-se o seu conceito etimológico, a fim de delimitar o campo de incidência de nossa pesquisa.

Para Alcides Tomasetti Jr., a informação consiste na "conformação aplicada a um certo dado, o qual, por força dessa conformação, torna-se passível de ser conhecido e, por cnseqüência, comunicável”. Segundo seus ensinamentos, informação é uma palavra "que se refere tanto ao processo de formulação e transmissão de dados cognoscíveis, como também a esses últimos, na exata medida em que estão no conteúdo e na resultante daquele processo". 319

Por outro lado, pela leitura do Dicionário Latino-Português, organizado pelo Pe. H. Koehler S. J., é possível verificar que o sentido etimológico da palavra informação ${ }^{320}$ descende do vocábulo latino informatio, que então significava definição,

319 Alcides Tomasetti Jr., O objetivo da transparência e o regime jurídico dos deveres e riscos de informação nas declarações negociais para consumo, Revista de Direito do Consumidor, n. 4 (Número especial), São Paulo: RT, 1992, p. 54.

320 De acordo com o Dicionário Houaiss da Língua Portuguesa, o verbete informação apresenta os seguintes significados: "Informação (s. f.) ato ou efeito de informar (-se) 1. comunicação ou recepção de um conhecimento ou juízo 2. o conhecimento obtido por meio de investigação ou instrução; esclarecimento, explicação, indicação, comunicação, informe 3. acontecimento ou fato de interesse geral tornado do conhecimento público ao ser divulgado pelos meios de comunicação; notícia 4. em âmbito burocrático, esclarecimento processual dado ger. por funcionário de apoio à autoridade competente na solução ou despacho de requerimento, comunicação etc. 5. informe escrito; relatório 6. conjunto de atividades que têm por objetivo a coleta, o tratamento e a difusão de notícias junto ao público Ex.: liberdade de i. 7. conjunto de conhecimentos reunidos sobre determinado assunto Ex.: a i. existente sobre a nova doença é insuficiente 8. elemento ou sistema capaz de ser transmitido por um sinal ou combinação de sinais pertencentes a um repertório finito 9. Rubrica: comércio. opinião ou parecer que contém dados sobre uma pessoa física ou sobre a evolução de uma pessoa jurídica Ex.: revelaram-se boas as i. sobre o fornecedor 10. Rubrica: comunicação. quantidade numérica que mede a incerteza do resultado de um experimento a realizarse; medida quantitativa do conteúdo da informação 11. Rubrica: informática. mensagem suscetível 
instrução, formação moral e intelectual, ideia; e que provém do verbo informo, no sentido de formar, dar certo feitio ou forma a alguma coisa, imaginar, organizar, instruir, educar, descrever. ${ }^{321}$

Como se vê, ressalta-se do conceito etimológico da palavra informação a ideia de instrução, bem como de formação, seja moral ou intelectual, o que salienta a importância da ação informativa no âmbito das relações intersubjetivas.

Por outro lado, em seu sentido etimológico o vocábulo conselho ${ }^{322}$ provém

do latino concilium e exprime a ideia de aconselhar-se, deliberação, plano, propósito,

de ser tratada pelos meios informáticos; conteúdo dessa mensagem 12. Rubrica: informática. interpretação ou significado dos dados 13. Rubrica: informática. produto do processamento de dados 14. Rubrica: termo militar. Regionalismo: Brasil. conjunto de informes (documentos ou observações) já analisados, integrados e interpretados, que habilita um comandante a tomar decisões seguras relativas a uma linha de ação e à conduta da manobra (mais us. no pl.) 15. Rubrica: direito falimentar. fase inicial do processo falimentar onde são apurados os bens, direitos e obrigações do falido 16. Rubrica: direito administrativo. ato pelo qual órgão da administração pública faz esclarecimentos sobre o processo administrativo 17. Rubrica: direito processual. conjunto de dados fornecidos pela autoridade impetrada no habeas corpus sobre o fato que se quer qualificar como abusivo 18. Rubrica: termo de garimpo. sinal de possível existência de diamantes nas adjacências, dado pela presença de satélites ('minerais')" (Dicionário Houaiss da Língua Portuguesa, Elaborado no Instituto Antonio Houaiss de Lexicografia e Banco de Dados da Língua Portuguesa Ltda. [Org. Antonio Houaiss e Mauro de Salles Villar], Rio de Janeiro: Objetiva, 2003, p. 1.615).

321 Dicionário Escolar Latino-Português, Org. Pe. H. Koehler S. J., 5. ed., Porto Alegre: Globo, 1953, p. 408.

322 “Conselho (s. m.) 1. opinião, ensino ou aviso quanto ao que cabe fazer; opinião, parecer Ex.: [dar, pedir, seguir um c.] [c. de amigo] 2. bom senso; sabedoria; prudência Ex.: [um homem digno e de c.] [opinião cheia de c.] 3. opinião refletida ou resolução maduramente tomada Ex.: só aja com c. 4. Derivação: por metonímia. grupo de pessoas apontado ou eleito como corpo consultivo e/ou deliberativo e/ou administrativo, seja de atividades públicas, seja de atividades privadas Ex.: [C. Nacional de Cultura] [c. de gestão] [c. de redação] 5. Derivação: por extensão de sentido. Rubrica: termo jurídico. organismo público destinado ao assessoramento de alto nível e de orientação e, às vezes, de deliberação, em vários campos da atuação do governo 5.1. corpo executivo cujos membros têm, todos, poder e autoridade igual 5.2 assembléia ou reunião de ministros Ex.: C. de Estado 5.3. tribunal, esp. militar Ex.: c. de guerra 5.4. reunião de pessoas para deliberarem sobre assuntos particulares Ex.: c. de família 5.5. assembléia ou reunião de professores universitários, de escolas superiores ou de escolas secundárias, para analisar e deliberar, sob a presidência de um reitor ou diretor, acerca de assuntos de ensino e administração 5.6. grupo de diretores de uma empresa, presididos pelo diretor-geral ou pelo presidente 6. Derivação: por metonímia. deliberação em conselho 7. Derivação: por metonímia. local onde se reúne um conselho Ex.: nosso c. é um prédio de linhas avançadas 8. Derivação: por metonímia. sessão de um conselho Ex.: hoje não houve c. 9. Rubrica: maçonaria. design. que se dá a algumas lojas maçônicas nos graus capitulares, filosóficos e administrativos 9.1. Rubrica: maçonaria. agremiação maçônica de rito escocês cuja atividade é do grau $30^{\circ}$ (filosófico, dos Cavaleiros Kadosch) 10. Rubrica: religião. desígnio (de Deus, da Providência) em relação à conduta dos homens 11. Rubrica: religião. aquilo que é recomendado para a consecução do aperfeiçoamento moral e espiritual [É deixado por conta do arbítrio humano, ao contrário dos preceitos e mandamentos.] Ex.: c. evangélicos 12. Rubrica: religião. um dos dons do Espírito Santo, que capacita o homem a ajuizar, sem reflexão e como que por intuição, o que é certo fazer em cada caso" (Dicionário Houaiss da Língua Portuguesa, cit., p. 807). 
projeto, prudência, além da ideia de um colégio de conselheiros; descendendo do verbo consilior - aconselhar-se com alguém, deliberar em conselho. ${ }^{323}$

E da leitura do Dicionário Latino-Português é possível verificar que o vocábulo commendatio significa recomendação, ${ }^{324}$ louvor, enquanto o verbo commendo apresenta o sentido de confiar, entregar alguma coisa a alguém, mas também possui o significado de recomendar ou de recomendar alguém a outro com muito empenho. ${ }^{325}$

Em sua clássica obra, Jorge Ferreira Sinde Monteiro define a informação como "a exposição de uma dada situação de fato, verse ela sobre pessoas, coisas, ou qualquer outra relação". Diferentemente do conselho e da recomendação, a pura informação esgota-se na comunicação de fatos objetivos, estando ausente uma (expressa ou tácita) proposta de conduta. ${ }^{326}$

Segundo sua lição, “o conselho significa dar a conhecer a uma outra pessoa o que, na sua situação, se considera melhor ou mais vantajoso e o próprio faria se estivesse no seu lugar"; enquanto a recomendação seria uma subespécie de conselho, traduzindo-se pela "comunicação de boas qualidades acerca de uma pessoa ou de uma coisa, com a intenção de, com isso, determinar aquele a quem é feita a algo".327

No presente trabalho partiremos da premissa oferecida por Sinde Monteiro, por julgarmos a mais adequada para o desenvolvimento de nossa pesquisa, não sem antes discorrer acerca da dificuldade de distinguir o conselho e a recomendação da simples opinião.

\footnotetext{
323 Dicionário Escolar Latino-Português, cit., p. 178.

324 "Recomendação (s. f.) 1. ato ou efeito de recomendar 2. Derivação: por metonímia. aquilo que adverte; conselho, advertência, aviso Ex.: esquecia com freqüência as $r$. da mãe 3. qualidade de recomendável Ex.: a grande clientela é sua melhor r. *recomendações (s.f.p.) 4. ação ou modo de dar provas de cortesia; cumprimentos, saudações, lembranças" (Dicionário Houaiss da Língua Portuguesa, cit., p. 2.402).

325 Dicionário Escolar Latino-Português, cit., p. 151.

326 Jorge Ferreira Sinde Monteiro, Responsabilidade por conselhos, recomendações ou informações, Coimbra: Almedina, 1989, p. 14-15.

327 Idem, ibidem, p. 15.
} 
Kant ressalva que uma simples opinião "nada mais é que um jogo da imaginação sem a menor relação com a verdade", ${ }^{328}$ o que levaria à conclusão de que não haveria como se responsabilizar aquele que a transmitiu.

Para o filósofo alemão a opinião, a fé e a ciência seriam graus da crença. Assim, "a opinião é uma crença que tem consciência de ser insuficiente tanto subjetiva quanto objetivamente". A fé, por sua vez, subjetivamente suficiente, mas, ao mesmo tempo, considerada como objetivamente insuficiente. Por fim, "a crença suficiente tanto subjetiva como objetivamente, é chamada de ciência". 329

Partindo-se desses conceitos, apenas a informação transmitida enquanto ciência teria relação com a verdade, o que faz com que os conselhos e as recomendações sejam simples opiniões, quando desprovidos de qualquer intenção de transmissão de conhecimento.

Caso contrário, se apresentados com algum conhecimento de causa, baseados em princípios de experiência ou em manifestações de atividades profissionais, poderiam gerar responsabilidade para quem os deu.

Perquirir acerca da natureza da informação, do conselho e da recomendação e do momento em que podem gerar responsabilidade consiste na essência do presente trabalho.

Trata-se de questão fundamental para o desenvolvimento desta tese, eis que a dificuldade de estabelecer a relação de causalidade entre a informação, o conselho ou a recomendação e o dano constitui óbice considerável para a imputação de responsabilidade ao agente.

Difícil é proceder à delimitação das relações contratuais, dissociando-as das atividades que não geram obrigações, das puras obsequiosidades, tornando-se

\footnotetext{
328 Immanuel Kant, Crítica da razão pura, cit., p. 516.

329 Idem, ibidem, p. 516.
} 
necessário, consoante ressalva Sinde Monteiro, “apreciar globalmente o comportamento das partes, tendo em conta as circunstâncias concretas". 330

Por outro lado, importa também proceder à análise da responsabilidade pelas informações, conselhos ou recomendações prestados no momento da formação do contrato, a chamada responsabilidade pré-contratual. ${ }^{331}$

É notória a questão acerca do fundamento da responsabilidade précontratual, que "nem parece ser contratual, porque ainda não há contrato, nem parece ser conveniente qualificá-lo como extracontratual, eis que estando os candidatos a contraentes em negociações, têm eles entre si, deveres específicos”, conforme ensina Antonio Junqueira de Azevedo. ${ }^{332}$

Além da controvérsia acerca do fundamento da responsabilidade précontratual, no presente trabalho existe uma questão essencial a ser discutida, que consiste na busca de um parâmetro para estabelecer quais as informações, conselhos e recomendações vinculam o contratante, apresentando um potencial danoso efetivo e, por conseguinte, o dever de indenizar o ofendido.

Da mesma forma, faz-se mister discorrer acerca da responsabilidade pelas informações, conselhos ou recomendações dados durante o processo contratual,

330 Jorge Ferreira Sinde Monteiro, Responsabilidade por conselhos, recomendações ou informações, cit., p. 462.

331 "Responsabilidade civil. Contrato. Princípio da boa-fé objetiva. Dever de informação. Direito à indenização. Recurso conhecido e não provido. I - Os contratantes devem observar, tanto na fase pré-contratual, como também na execução e conclusão do negócio jurídico, parâmetro de conduta pautada pela probidade e boa-fé, a fim de que o contrato atinja sua função social, e, ao mesmo tempo, atenda às legítimas expectativas das partes. II - $\mathrm{O}$ fornecedor deve assegurar ao consumidor informações corretas, claras e precisas acerca dos serviços oferecidos, notadamente sobre os riscos envolvidos na prestação. III - Não se verifica ofensa ao princípio da boa-fé objetiva, nem descumprimento do dever de informação, quando a empresa prestadora do serviço de fertilização in vitro informa a paciente acerca dos riscos e probabilidades de insucesso da gravidez decorrente do procedimento. IV - Ausente a comprovação da existência de defeito na prestação do serviço, descumprimento das obrigações contratuais, tampouco a prática de ato ilícito, não há falar-se em direito à indenização" (TJMG, APCV 1.0027.05.078388-8/0011, Betim, 15. ${ }^{a}$ Câm. Cív., rel. Des. Bitencourt Marcondes, j. 13.03.2008, DJEMG 04.04.2008).

332 Antonio Junqueira de Azevedo, Responsabilidade pré-contratual no Código de Defesa do Consumidor: Estudo Comparativo com a responsabilidade pré-contratual no direito comum, Revista de Direito do Consumidor, n. 18, São Paulo: RT, 1996, p. 23. 
partindo-se da conclusão do contrato, passando-se pela análise de sua eficácia, para ao final abordar a fase de execução e do adimplemento contratual.

Desse modo, serão analisados os fundamentos do inadimplemento contratual, os termos e limites da obrigação de informar, prestar conselhos ou dar recomendações, posto que a responsabilidade decorrerá do espontâneo descumprimento de uma obrigação, de seu cumprimento inadequado ou da violação de deveres anexos à boa-fé objetiva.

Deve-se, ainda, proceder ao estudo da responsabilidade decorrente dos contratos celebrados entre particulares em que a informação, o conselho e a recomendação são essenciais para a formação da convicção dos contratantes, bem como para o implemento das obrigações estipuladas no instrumento contratual. Nessas hipóteses, torna-se necessário analisar a responsabilidade do profissional que exerce uma atividade em que o aconselhamento, a recomendação e a informação são essenciais ao seu mister, tais como o médico, o advogado, o psicólogo ou o contador.

Mas não é só. Eis que a responsabilidade pelas informações, conselhos ou recomendações prestados na fase pós-contratual ${ }^{333}$ também apresenta destacada importância para o presente estudo.

Isso porque, havendo violação dos denominados deveres anexos ou acessórios (informação, proteção ou lealdade), mesmo após a extinção do contrato, exsurge a responsabilidade pós-contratual. ${ }^{334}$

333 "Indenização por danos materiais e morais. Informações contendo erro material quanto ao período trabalhado prestadas pela empresa ré a respeito de antiga empregada. Competência da justiça comum, em razão da sentença de primeiro grau ter sido proferida antes da EC 45/2004. Responsabilidade pós- contratual e violação de deveres laterais com origem na boa-fé objetiva" (TJSP, AC 361.396.4/4, Ac. 3352670, Barueri, 4. ${ }^{a}$ Câm. de Dir. Privado, rel. Des. Francisco Eduardo Loureiro, j. 13.11.2008, DJESP 15.12.2008).

334 Rogério Ferraz Donnini, Responsabilidade civil pós-contratual, 2. ed., São Paulo: Saraiva, 2007, p. 106. 
Assim, os deveres de conduta que possuem sua causa no contrato, mas que se projetam no tempo, até depois de sua extinção, tais como o dever de sigilo empresarial ou dever de prestar referências pelo empregador, justificam o estudo detalhado no presente capítulo.

Por outro lado, há que se ressaltar o fato de existirem situações em que a troca de informações, conselhos e recomendações não se encontra amparada por uma relação contratual, mas, mesmo assim, é capaz de gerar responsabilidade.

De fato, é possível a ocorrência de dano que não decorra de qualquer avença, mas apenas de um aconselhamento que tenha criado uma justa expectativa em seu destinatário. Da mesma forma, pode acontecer que um simples recomendar demonstre-se, posteriormente, absolutamente despropositado, fazendo com que a representação tida por efetiva pela pessoa que recebeu a recomendação acabe por não se concretizar no plano fático e seja fonte de prejuízo indenizável. O mesmo acontece com informações prestadas a esmo, dissociadas de qualquer vínculo contratual, mas que constituem fonte de danos em potencial.

Como se vê, inúmeras são as hipóteses potencialmente geradoras de responsabilidade, em decorrência da troca de informações entre particulares, assim como de aconselhamentos e recomendações, razão pela qual se torna necessário proceder ao seu estudo, nos itens que se seguem.

No entanto, a busca por soluções equilibradas para o problema da responsabilidade civil pelas informações, conselhos e recomendações passa, necessariamente, pela análise do tema relacionado à responsabilidade pré-contratual, fonte de intensa controvérsia, especialmente relacionada à sua natureza jurídica, que, acreditamos, pode ser resolvida através da tese aqui proposta, acerca da existência de uma responsabilidade pela confiança. 
Por essa razão, faz-se necessário proceder ao estudo da responsabilidade pré-contratual, assim como de sua natureza jurídica, sob a perspectiva da atual base valorativa de nosso ordenamento.

\subsection{A responsabilidade pela informação, o conselho e a recomendação, na fase pré-contratual}

A questão atinente à responsabilidade pelas informações, conselhos e recomendações na fase pré-contratual constitui ponto fulcral de nossa tese, devido à possibilidade de ocorrência de incomensurável gama de situações potencialmente causadoras de danos no momento das tratativas negociais, aliada às controvérsias acerca da própria responsabilidade pré-contratual e de sua natureza jurídica.

De fato, é cediço que à conclusão do contrato precede, normalmente, uma fase de negociações - comumente denominada de negociações preliminares ou de fase das tratativas -, em que parte e contraparte se aproximam, buscando uma forma de compor os seus interesses, discutindo as condições do negócio e procurando alcançar uma posição satisfatória para todos, a fim de tornar possível a celebração do acordo.

Nessa fase, anterior à conclusão do contrato, ainda não existe uma proposta efetiva, certa e determinada, capaz de vincular o proponente.

Porém, é, em regra, por intermédio dessas negociações que as partes intentam formular termos e condições do futuro pacto que permitam conjugar os distintos e contrapostos interesses e viabilizem a conclusão da avença.

Contudo, existe acirrada controvérsia acerca da natureza da responsabilidade pré-contratual, que merece ser analisada antes de se chegar a qualquer conclusão acerca da responsabilidade por informações, conselhos ou recomendações decorrentes das tratativas. 


\subsubsection{A responsabilidade pré-contratual}

Rudolph von Jhering, no ano de 1861, defendeu a tese de que nos momentos que antecedem a conclusão do contrato constitui-se entre as partes negociantes uma relação obrigacional integrada por deveres de conduta cuja violação impõe ao infrator o dever de reparar os danos causados à outra parte. ${ }^{335}$

Como mostram Henri Mazeaud, Léon Mazeaud e André Tunc, Jhering foi o primeiro a examinar o problema a fundo, partindo do direito romano para chegar à conclusão de uma responsabilidade contratual em decorrência da "culpa in contrahendo". 336

Após colocar a culpa in contrahendo no rol das descobertas jurídicas mais significativas da época contemporânea, Menezes Cordeiro salienta que Jhering logrou demonstrar a possibilidade de ocorrência de danos no momento da formação do contrato, decorrentes de anomalias que acarretassem sua nulidade, cujo não ressarcimento seria injusto. Diante disso, caberia ao responsável pela invalidade do contrato indenizar pelo interesse contratual negativo, trazendo o prejudicado à situação em que se encontraria caso nunca tivesse negociado e não houvesse um contrato nulo. ${ }^{337}$

Recorrendo a exemplos e a casos práticos, Jhering demonstra que o erro cometido na fase de conclusão de contrato e que acarretaria a sua nulidade deveria, para evitar situações de injustiça, ensejar o dever de ressarcir a parte prejudicada. Assim, ao analisar textos do Digesto, verificou a possibilidade de se imputar ao contratante o dever

335 Rudolph von Jhering, Culpa in contraendo oder Schadensersatz bei nichtigen oder nicht zur Perfektion gelangten Verträgen, Ihering Jarbücher für die Dogmatik des bürgerlichen Rechts, 1861.

336 No original: "Jhering fue el primero que examinó a fondo el problema. Partiendo del derecho romano, llegó a la conclusión de la responsabilidad contractual” (Henri Mazeaud; Léon Mazeaud; André Tunc, Tratado teórico y práctico de la responsabilidad civil delictual y contractual, 5. ed., tradução de Luis Alcalá-Zamora Y Castillo, Buenos Aires: Ediciones Jurídicas Europa-América, 1957, t. I, v. 1, p. 166).

337 António Manuel da Rocha e Menezes Cordeiro. Tratado de direito civil português. Parte geral, cit., p. 498-499. 
de reparar à contraparte o dano decorrente da nulidade do contrato em virtude de um comportamento culposo praticado no momento de sua formação. ${ }^{338}$

Com o mérito de ser o pioneiro a fazer um aprofundado estudo sobre o tema, Jhering centrou sua análise na culpa decorrente da celebração de um contrato inválido. Deste modo, aquele que, ao negociar com outrem, adote uma conduta desleal ou não diligente, de forma que o contrato esteja eivado de nulidade, deverá reparar os danos que porventura decorram desta atitude.

Antônio Chaves afirma que a teoria de Jhering poderia ser resumida em uma sentença: aquele que entra em relações contratuais com outra pessoa por este fato está obrigado a proporcionar-lhe um contrato que seja válido e deve, por conseguinte, indenizar o trabalho e as despesas havidas pela contraparte na certeza de que alcançaria o resultado almejado pela avença. ${ }^{339}$

Assim, de acordo com essa teoria, também conhecida por teoria da base contratual pura, é contratual a responsabilidade decorrente do ato culposo que acarretou a invalidade do pacto, não obstante o fato de o contrato ainda não ter sido celebrado, pois a origem da culpa se verifica no momento em que as partes pretendem a celebração da avença.

Em belo trabalho, Mariana Pazianotto Deperon ressalta que a teoria proposta por Jhering apresenta quatro elementos essenciais: a) o dever de indenizar surge no momento da conclusão aparente do contrato, quando uma das partes, culposamente, pratica um ato que provoca a sua nulidade (culpa in contrahendo); b) devem as partes conservar certo nível de diligência em toda a relação contratual; c) somente os contratantes podem ser sujeitos da reparação ou do dever de reparar, conforme o caso, não sendo possível que referido direito ou dever seja imputado a terceiros alheios à relação contratual; e d) o dever de indenizar decorrente da responsabilidade in contrahendo não implicaria o dever de dar à parte prejudicada

\footnotetext{
338 Mariana Pazianotto Deperon, Responsabilidade civil pela ruptura ilegítima das tratativas, cit., p. 2122.

339 Antônio Chaves, Responsabilidade pré-contratual, Rio de Janeiro: Forense, 1959, p. 112.
} 
prestação equivalente à prestação objeto do contrato, o que significa que um contrato nulo não ensejaria o nascimento de qualquer dever de execução, mas apenas acarretaria o dever de trazer a parte prejudicada para uma situação patrimonial idêntica àquela em que se encontraria se não tivesse intentado concluir o negócio declarado inválido em razão da culpa da outra parte. ${ }^{340}$

Como se vê, a teoria do mestre alemão concentra a sua base na hipótese de um dos contratantes ter levado a contraparte a celebrar um contrato inválido, em virtude de uma atitude culposa, daí decorrendo o dever de indenizar resultante da responsabilidade contratual, muito embora o dano tenha ocorrido em um momento posterior à conclusão do negócio.

Como bem ressalva Inocêncio Galvão Telles, "a idéia de culpa in contrahendo foi uma genial 'descoberta jurídica' do insigne Jhering” e representa a pedra fundamental de toda a discussão atinente à responsabilidade pré-contratual.

No entanto, isso não significa dizer que esteja alheia a críticas e a intensa controvérsia, o que pode ser sintetizado pelas palavras de Henri Mazeaud, Léon Mazeaud e André Tunc, ao afirmarem que, para fundamentar a responsabilidade contratual em um momento anterior à celebração do pacto, Jhering pretende descobrir um acordo de vontades por pura ficção, pois se não existe contrato, não há, por conseguinte, responsabilidade contratual. ${ }^{341}$

Além disso, na opinião dos doutrinadores franceses a falha na teoria do mestre germânico origina-se justamente do fato de buscar no direito romano embasamento para a sua tese, posto que, diferentemente do direito francês, os romanos não conheciam um princípio geral de responsabilidade delitual suscetível de ser

340 Mariana Pazianotto Deperon, Responsabilidade civil pela ruptura ilegítima das tratativas, cit., p. 2728.

341 Henri Mazeaud; Léon Mazeaud; André Tunc, Tratado teórico y práctico de la responsabilidad civil delictual y contractual, cit., 1957, t. I, v. 1, p. 166-167. 
aplicado em qualquer situação, o que só permitiria que buscassem uma solução na responsabilidade contratual. ${ }^{342}$

Outrossim, a teoria da culpa in contrahendo de Rudolph von Jhering limitase aos casos de ocorrência de dano decorrente da invalidade do contrato celebrado entre as partes, mas não se estende às hipóteses de ruptura injustificada das tratativas, também potencialmente lesivas àquele que alimentava justa expectativa pela celebração do pacto.

Coube ao jurista italiano Gabrielle Fagella "o mérito da extensão da responsabilidade pré-contratual aos casos de ruptura injustificada das negociações preliminares", ao ressalvar o fato de que a responsabilidade in contrahendo não se limita ao campo da invalidade dos contratos conforme sustentava Rudolph von Jhering, mas compreende também os casos de interrupção injusta das tratativas por uma das partes, causando danos à outra, pois o dever de reparar encontraria a sua origem no abrupto recesso das negociações preliminares por um dos futuros contratantes, sem que houvesse a necessidade de caracterizar o dolo ou a negligência do responsável pela ruptura das tratativas. ${ }^{343}$

Mas essa não é a única ressalva feita à teoria de Jhering, posto que, além das ideias esposadas pelo jurista italiano, inúmeras são as teorias que visam a explicar o fundamento da responsabilidade pré-contratual ou a negar a sua existência. ${ }^{344}$

342 Henri Mazeaud; Léon Mazeaud; André Tunc, Tratado teórico y práctico de la responsabilidad civil delictual y contractual, cit., 1957, t. I, v. 1, p. 167.

343 Mariana Pazianotto Deperon, Responsabilidade civil pela ruptura ilegítima das tratativas, cit., p. 3132, em comentários à obra de Gabrielle Fagella: Dei periodi precontrattuali e della loro vera ed esatta costruzione scientifica, Studi Giuridici in onore di Carlo Fadda, Napoli, [s.n.], 1960, p. 300. "No espaço latino, a apresentação de soluções legais para o tema da culpa in contrahendo deve-se a FAGGELA. Esse autor veio defender, no essencial, e em termos que, de algum modo, representam uma transição, a possibilidade de responsabilizar as partes nos períodos pré-contratuais, com base na conjunção entre a assunção livre de uma situação de negociações preliminares e o infligir de um dano patrimonial à contraparte" (António Manuel da Rocha e Menezes Cordeiro, Da boa-fé objetiva no direito civil, cit., p. 540).

344 Para um estudo das inúmeras teorias que visam à fundamentação da responsabilidade pré-contratual, confira-se a obra de Antônio Chaves, Responsabilidade pré-contratual, cit. Ver também o trabalho de Mariana Pazianotto Deperon, Responsabilidade civil pela ruptura ilegítima das tratativas, cit. 
Existem ainda aqueles que refutam a existência de responsabilidade précontratual, baseando seus argumentos no fato de ser facultado às partes o mais amplo debate sobre todos os termos do contrato, capaz de permitir a formulação de propostas e de contrapropostas, o que obrigaria o contratante a ser diligente e a não se comportar de maneira desidiosa quando da conclusão do contrato.

Esse é o entendimento básico dos sistemas de common law ${ }^{345}$, embora seja possível se verificar uma mudança no entendimento dos tribunais tanto na Inglaterra, como nos Estados Unidos. ${ }^{346}$

Ademais, a ideia de qualquer responsabilidade pré-contratual implicaria uma contradição, em virtude de importar em cerceamento da liberdade dos contratantes, que, muitas vezes, seriam forçados à celebração da avença, contra sua vontade, apenas para evitar uma possível indenização devida pela hipótese de não prosseguirem nas negociações preliminares, o que iria de encontro ao fato de ser o contrato um ato em que se exige o concurso do mútuo consentimento livre para sua formação. Reconhecer a possibilidade de existência de uma responsabilidade pré-contratual significaria tolher os contratantes de uma liberdade fundamental caracterizada pelo direito de retirar-se das negociações. ${ }^{347}$

345 "Nos sistemas de common law, por exemplo, rejeita-se a existência de qualquer vínculo obrigacional entre aqueles que negociam com vista à conclusão de um contrato, apenas se admitindo a imputação de danos causados in contrahendo nos termos da responsabilidade extracontratual" (Dario Moura Vicente, A responsabilidade pré-contratual no Código Civil Brasileiro de 2002. Texto que serviu de base às conferências proferidas pelo autor no Recife, em Brasília e em Porto Alegre, no âmbito da II Jornada de Direito Civil promovida pelo Conselho da Justiça Federal do Brasil entre 17 e 25 de Novembro de 2003. Disponível em: <http://www.fd.ul.pt/Portals/0/Docs/Institutos/ICJ/ LusCommune/VicenteDario4.pdf), acesso em: 20 nov. 2009.

346 "Embora o "tudo ou nada" esteja ainda muito vivo no que respeita na fase das negocial de uma transação, os tribunais dos Estados Unidos estão mais propensos a imposição da responsabilidade pré-contratual do que as cortes inglesas. A existência de uma carta de intenções intensifica as obrigações existentes na lei e, em algumas circunstâncias, pode causar a imputação de responsabilidade" (tradução livre). No original: "Although the "all or nothing" approach is still very much alive with respect to the negotiation phase of a transaction, U.S. courts are more willing to impose precontractual liability in general than are in English courts. The existence of a letter of intent intensifies obligations that exist in the law, and in some circumstances may cause the imposition of liability" (Ugo Draetta; Ralph Lake, Letters of intent and precontractual liability, International Business Law Journal, n. 7, 1993, p. 839).

347 Antônio Chaves, Responsabilidade pré-contratual, cit, p. 99-105. 
Todavia, esse direito de retirar-se das negociações não é absoluto nem autoriza uma das partes a causar dano à outra em virtude do inesperado e abrupto recesso das tratativas, evidenciando-se o abuso de direito do retirante em detrimento da legítima expectativa da contraparte.

Essa retirada abrupta das negociações, de forma desleal e afrontando os fins impostos pela boa-fé, gerando danos a outrem, caracteriza uma conduta lesiva ao direito e é repudiada por uma ordem jurídica fundada em valores éticos e no solidarismo social. $^{348}$

Não se pretende, com isso, afirmar que a ninguém seria dado o direito de retirar-se das negociações, mas apenas assinalar que o direito de recesso não pode ser exercido de forma excessiva e desmesurada, capaz de causar dano a outrem.

É exatamente na ponderação dos interesses envolvidos nas tratativas e no sopesamento do conflito entre os princípios da autonomia da vontade e da boa-fé objetiva que reside toda a complexidade da questão relacionada às chamadas negociações preliminares.

Neste contexto, deve-se evitar que uma retirada injustificada e abrupta das negociações cause dano à contraparte, preservando-se o padrão de conduta ético e leal que, espera-se, seja a base de todas as relações privadas, estejam elas amparadas por um contrato ou não, sem que isso signifique afronta letal à autonomia da vontade, também essencial para a vida em sociedade. ${ }^{349}$

\footnotetext{
348 "A pessoa é inseparável da solidariedade: ter cuidado com o outro faz parte do conceito de pessoa" (Pietro Perlingieri, O direito civil na legalidade constitucional, tradução de Maria Cristina De Cicco, Rio de Janeiro: Renovar, 2008, p. 461).

349 "A liberdade da tratativa, em outros termos, deve ser exercida de modo leal: se é criada uma confiança justificada e se retira, sem bom motivo, da negociação, incorre-se em responsabilidade." No original: "La libertà della tratativa, in altri termini, deve esser esercitata in modo leal: se si è creato un affidamento giustificato, e si recede senza buon motivo della tratativa, si incorre in responsabilità" (Guido Alpa, Corso di diritto contratuale, cit., p. 21-22).
} 
Por conseguinte, torna-se imperioso indagar acerca do papel da culpa in contrahendo, perquirindo sobre a natureza do instituto e dos interesses a serem tutelados.

\subsubsection{A natureza jurídica da responsabilidade pré-contratual}

De início, cabe ressaltar que nosso Código Civil se encontra assentado na clivagem entre os regimes de responsabilidade decorrente do ato ilícito e aquela que decorre de uma relação contratual, o que representa fonte de discussão sobre a natureza da responsabilidade pela ruptura das tratativas negociais, fazendo com que o tema seja origem de intenso debate doutrinário.

Por essa razão, a controvérsia acerca da natureza da responsabilidade précontratual ainda se mostra bastante latente, com diversos doutrinadores entendendo tratar-se de responsabilidade contratual e outros tantos defendendo sua natureza delitual. Há, ainda, aqueles que defendem a existência de um tertium genus, que se enquadraria entre o contrato e o ato ilícito, como uma terceira via de responsabilidade.

Neste contexto, defendendo a ideia de que o contrato é um processo, decorrente, como o próprio negócio jurídico, de uma "sucessão de tempos", que vai da fase pré-contratual à fase pós-contratual, passando pela fase contratual, que se distribui em três fases menores (conclusão do contrato, eficácia do contrato e execução/adimplemento do contrato), todas elas subordinadas à boa-fé objetiva, Antonio Junqueira de Azevedo entende que a responsabilidade pré-contratual deve se submeter ao tratamento da responsabilidade contratual. ${ }^{350}$

Este também é o entendimento de Carlyle Popp, para quem, em virtude da existência de um vínculo entre os negociantes, que decorre do conteúdo das tratativas e da conduta das partes e visa à celebração do contrato, a questão leva à conclusão no

\footnotetext{
350 Antonio Junqueira de Azevedo, Responsabilidade pré-contratual no Código de Defesa do Consumidor: Estudo comparativo com a responsabilidade pré-contratual no direito comum, cit., p. 23.
} 
sentido de que a "responsabilidade pré-negocial, de qualquer espécie, tem natureza contratual e, portanto, submeter-se-á a idêntico disciplinamento jurídico".351

Como se vê, os doutrinadores mencionados acabam por regressar às origens da teoria da culpa in contrahendo e, ainda que por motivos bastante diversos daqueles sustentados por Jhering, concluem pela natureza contratual da responsabilidade pela ruptura das tratativas.

Entretanto, vários são os autores que divergem desse entendimento e defendem a natureza aquiliana da responsabilidade pré-contratual, em especial por se tratar de dano ocorrido em momento anterior à celebração do pacto. ${ }^{352}$

Neste diapasão, comentando o sistema brasileiro, Mariana Pazianotto Deperon elenca os pontos que, em sua opinião, confirmam o acerto da tese pela natureza extracontratual: i) a fonte de onde provém o dever de ressarcir seria o diferenciador entre a responsabilidade contratual, que decorre do descumprimento de uma obrigação, legal ou avençada pelas partes, e a extracontratual, derivada do ato ilícito; ii) pela sistemática do Código Civil de 2002 a responsabilidade contratual verifica-se nos casos de inadimplemento contratual ou de um dever oriundo de uma relação obrigacional; iii) a boa-fé não cria entre as partes uma relação obrigacional, que decorre somente da lei ou do negócio jurídico, ainda que tenha imposto limites à liberdade de contratar, por meio de deveres específicos (art. 422) ou por meio da limitação aos exercícios dos

351 Carlyle Popp, Responsabilidade civil pré-negocial: o rompimento das tratativas, Curitiba: Juruá, 2001, p. 150.

352 Nesse sentido, confira-se a opinião de Henri Mazeaud, Léon Mazeaud e André Tunc: "Assim, enquanto não exista um contrato e desde o instante em que não exista esse contrato, os problemas de responsabilidade que possam surgir, inclusive por ocasião de um contrato futuro ou pretérito, seguem sendo problemas de responsabilidade delitual". No original: "Así, mientras que no exista contrato y desde el instante en que ya no haya contrato, los problemas de responsabilidad que puedan surgir, incluso con ocasión de un contrato futuro o pasado, siguen siendo problemas de responsabilidad delictual" (Henri Mazeaud; Léon Mazeaud; André Tunc, Tratado teórico y práctico de la responsabilidad civil delictual y contractual, cit., p. 171). Esse é o entendimento de Caio Mário da Silva Pereira, ao afirmar que, "não obstante faltar-lhe obrigatoriedade, pode surgir responsabilidade civil para os que participam das negociações preliminares, não no campo da culpa contratual, porém da aquiliana, somente no caso de um deles induzir no outro a crença de que o contrato será celebrado, levando-o a despesas ou a não contratar com terceiros etc. e depois recuar, causando-lhe dano. O fundamento do dever de reparação é o ilícito genérico" (Instituições de direito civil: contratos. Declaração unilateral de vontade. Responsabilidade civil, 13. ed., rev. e atual. por Régis Fichtner, Rio de Janeiro: Forense, 2009, v. 3, p. 32). 
direitos (art. 187); iv) na fase das tratativas a função da boa-fé consiste em proteger a confiança legítima despertada entre as partes; e $v$ ) as tratativas não geram entre as partes nenhum efeito vinculativo, posto que este efeito só nasce com a oferta, que vincula o policitante, ou com o contrato preliminar. ${ }^{353}$

Trata-se, como informa a própria autora, da tese majoritária em nosso direito, em virtude de ainda não existir um vínculo contratual ou obrigacional entre as partes na fase das tratativas. ${ }^{354}$

No entanto, as razões apresentadas em defesa da responsabilidade aquiliana no período de tratativas demonstram algumas lacunas, posto que em nosso sistema existe expressa previsão acerca da indenização decorrente de ato lícito, como, por exemplo, decorre do disposto no art. 188, inc. II, ${ }^{355}$ conjugado com os arts. $929^{356}$ e $930,{ }^{357}$ todos do Código Civil, eis que o primeiro dispositivo afasta a ilicitude do ato praticado em estado de necessidade, ao passo que os outros estabelecem o dever do autor do dano de indenizar a vítima, para depois exercer o direito de regresso contra o terceiro culpado por sua ocorrência.

Nestes casos, em que existe o dever de indenizar, não obstante a prática de um ato considerado lícito, evidencia-se a primazia do interesse da vítima e o

353 Mariana Pazianotto Deperon, Responsabilidade civil pela ruptura ilegítima das tratativas, cit., p. 228-229.

354 Idem, ibidem, p. 228.

355 “Art. 188. Não constituem atos ilícitos: I - os praticados em legítima defesa ou no exercício regular de um direito reconhecido; II - a deterioração ou destruição da coisa alheia, ou a lesão a pessoa, a fim de remover perigo iminente. Parágrafo único. No caso do inciso II, o ato será legítimo somente quando as circunstâncias o tornarem absolutamente necessário, não excedendo os limites do indispensável para a remoção do perigo."

356 “Art. 929. Se a pessoa lesada, ou o dono da coisa, no caso do inciso II do art. 188, não forem culpados do perigo, assistir-lhes-á direito à indenização do prejuízo que sofreram."

357 “Art. 930. No caso do inciso II do art. 188, se o perigo ocorrer por culpa de terceiro, contra este terá o autor do dano ação regressiva para haver a importância que tiver ressarcido ao lesado. Parágrafo único. A mesma ação competirá contra aquele em defesa de quem se causou o dano (art. 188, inciso I)." 
fundamento segundo o qual não se deve permitir que seja injustamente sacrificada, suportando um dano sem a devida reparação. ${ }^{358}$

Sobre o tema, Carlos Alberto da Mota Pinto salienta que, muito embora possa parecer um paradoxo o fato de o direito considerar um determinado ato como lícito e, mesmo assim, impor ao seu autor a obrigação de indenizar outrem, este fato não constitui uma contradição, pois o que se pretende em tais casos "é compensar o sacrifício de um interesse menos valorado na composição de um conflito teleológico, porque uma prevalência absoluta e total do interesse oposto seria injusta". Por conseguinte, nestas hipóteses expressamente reconhecidas pela lei como de responsabilidade por atos lícitos, os danos não são causados por uma atividade contrária ao sentido em que o direito resolveu o conflito de interesses. Isso porque a atividade do agente ocorre secundum jus, ao contrário do que acontece nas hipóteses de ato ilícito em que um comportamento rebelde do agente lesa o interesse que o direito quer fazer prevalecer. Assim, apesar de o sujeito agir conforme o direito, pareceu excessivo não dar à pessoa sacrificada uma reparação. ${ }^{359}$

Como se vê, é possível que alguém seja condenado a reparar o dano causado a outrem, ainda que não tenha cometido um ato lícito, o que vai de encontro ao argumento de que a fonte de onde provém o dever de ressarcir na responsabilidade extracontratual seja sempre proveniente da ilicitude.

Por outro lado, a assertiva no sentido de que, pela atual sistemática do Código Civil, a responsabilidade contratual se verifica apenas nos casos de inadimplemento contratual ou de um dever oriundo de uma relação obrigacional, ${ }^{360}$ não

358 Neste sentido, observa António Manuel da Rocha e Menezes Cordeiro que "a imputação por fato lícito ou pelo sacrifício postula o cometimento voluntário de um dano, mas em termos tais que sua prática não possa ser considerada como ilícita. Não obstante, o Direito, tendo em conta que o autor do dano pode dele retirar vantagens, considera como injusto uma sua suportação, apenas, pelo titular da vantagem frustrada. Estabelece uma imputação dos danos verificados ao autor do comportamento ainda lícito" (Tratado de direito civil português. Parte geral, cit., p. 42).

359 Carlos Alberto da Mota Pinto, Teoria geral do direito civil, 3. ed., Coimbra: Coimbra Ed., 1996, p. 122.

360 Mariana Pazianotto Deperon, Responsabilidade civil pela ruptura ilegítima das tratativas, cit., p. 229. 
está livre de críticas, eis que a fronteira entre a responsabilidade derivada do contrato e aquela que exsurge da ilicitude é cada vez mais tênue.

Ora, em nosso ordenamento jurídico a fluidez da fronteira entre a responsabilidade contratual e a responsabilidade aquiliana pode ser demonstrada, por exemplo, pelo recorrente recurso ao art. $402^{361}$ do Código Civil para fundamentar a reparação dos danos emergentes e dos lucros cessantes resultantes do ato ilícito ou pelo constante uso dos arts. $406^{362}$ e $407^{363}$ do Código Civil para fixar os juros decorrentes da prática de um ilícito.

Essa linha tênue entre a responsabilidade contratual e a extracontratual tem sido assinalada também em outros ordenamentos jurídicos, consoante bem observa Ricardo Luis Lorenzetti ao afirmar que, não obstante a responsabilidade civil apresentar dois âmbitos, a rigidez da fronteira tem sido flexibilizada por uma interpretação doutrinária e jurisprudencial orientada em direção à unificação. ${ }^{364}$

No direito francês, Patrice Jourdain ressalva a perda da importância da distinção entre os dois regimes de responsabilidade, ressalvando que essa clivagem responsabilidade contratual e aquiliana constitui fonte maior de dificuldades. ${ }^{365}$

Destarte, a discussão acerca da natureza da responsabilidade pré-contratual esbarra em diversas lacunas, seja para aqueles que entendem tratar-se de uma relação contratual, seja para os que defendem sua natureza extracontratual, o que abre espaço

361 “Art. 402. Salvo as exceções expressamente previstas em lei, as perdas e danos devidas ao credor abrangem, além do que ele efetivamente perdeu, o que razoavelmente deixou de lucrar."

362 “Art. 406. Quando os juros moratórios não forem convencionados, ou o forem sem taxa estipulada, ou quando provierem de determinação da lei, serão fixados segundo a taxa que estiver em vigor para a mora do pagamento de impostos devidos à Fazenda Nacional."

363 “Art. 406. Quando os juros moratórios não forem convencionados, ou o forem sem taxa estipulada, ou quando provierem de determinação da lei, serão fixados segundo a taxa que estiver em vigor para a mora do pagamento de impostos devidos à Fazenda Nacional."

364 No original: "La responsabilidad civil tiene, en el Derecho vigente, dos ámbitos, pero la rigidez de la frontera ha sido flexibilizada por una interpretación doctrinaria y jurisprudencial orientada hacia la unificación” (Ricardo Luis Lorenzetti, Tratado de los contratos: parte general, cit., p. 589).

365 No original: "Bien qu'elle air perdu de son importance, cette distinction traditionnelle entre deux ordres de responsabilitè est une autre source majeure - et trés actuelle - de difficultés" (Patrice Jourdain, Les principes de la responsabilité civile, 2. ed., Paris: Dalloz, 1994, p. 31). 
para a construção de uma via alternativa, baseada na ideia de que as negociações preliminares ensejariam uma terceira via de responsabilidade - um tertium genus.

No Brasil, Régis Fichtner Pereira defende a existência dessa terceira via ao afirmar que, tanto do sistema de responsabilidade civil contratual como do sistema de responsabilidade civil delitual, não podem ser obtidas soluções satisfatórias para as mais diversas questões surgidas na fase das negociações preliminares, o que torna necessária a criação de um sistema próprio de responsabilidade pré-contratual. ${ }^{366}$

Nesse sentido, Karina Nunez Fritz observa que durante a fase de preparação do negócio, através do contato negocial, surge uma gama de deveres que caracteriza uma relação jurídica especial e uma vinculação especial, denominada de Sonderverbindung, pelos alemães, que consiste em uma relação obrigacional distinta da relação obrigacional típica e marcada pela presença do dever de prestação. Assim, segundo suas palavras, em virtude da especificidade dessa vinculação, presente no período pré-contratual, tem fundamento a tese de que a responsabilidade pré-contratual consistiria em um terceiro gênero de responsabilidade civil, distinto da contratual e da extracontratual. $^{367}$

Em nosso entendimento, contudo, tanto a responsabilidade contratual como a responsabilidade extracontratual pertencem ao gênero responsabilidade civil, constituindo apenas regimes distintos e não diferentes espécies de responsabilidade, posto não vislumbrarmos a existência de uma diferença entre a natureza da obrigação decorrente do contrato e do delito, o que já afirmamos anteriormente.

Neste sentido, Guido Alpa adverte para o fato de que não existiria uma diferença de natureza entre as obrigações contratuais e as extracontratuais, mas apenas

\footnotetext{
366 Régis Fichtner Pereira, A responsabilidade pré-contratual, Rio de Janeiro: Renovar, 2001, p. 257.

367 Karina Nunes Fritz, Boa-fé objetiva na fase pré-contratual. A responsabilidade pré-contratual por ruptura das negociações, cit., p. 274.
} 
diferentes regimes. Essa a razão da crítica contemporânea à distinção, fundamentada no método comparativo entre esses dois regimes e tratando de atenuar suas diferenças. ${ }^{368}$

Ora, o princípio da boa-fé objetiva permeia-se por todas as relações intersubjetivas, independentemente de estarem amparadas por um contrato ou não, ${ }^{369}$ estabelecendo um padrão de conduta ético que, violado, gera responsabilidade, até mesmo tratando-se de atos lícitos, como já visto anteriormente. Esses fatos contribuem para obnubilar ainda mais a já tênue distinção entre a responsabilidade contratual e a extracontratual.

Assim, em nossa opinião, a dicotomia responsabilidade contratualextracontratual não é suficiente para resolver o problema em questão, que envolve fatores muito mais complexos e abrange inúmeras possibilidades, as quais não podem ser resumidas pela existência ou não de um vínculo contratual.

Por essas razões, importa ao presente trabalho analisar essa nova perspectiva do direito civil, a responsabilidade pela confiança, sopesando-se a irradiação dos princípios constitucionais e da proteção dos direitos fundamentais com as regras de direito privado, a fim de buscar um critério para a apuração da responsabilidade pelas informações, conselhos e recomendações nas relações entre particulares.

Não obstante, nossa análise não pode estar apartada do sistema jurídico brasileiro, que reconhece a clivagem entre responsabilidade contratual e extracontratual, estabelecendo distintos efeitos para ambas, razão pela qual a conclusão de nossa tese deverá levar em conta, necessariamente, esse regime dicotômico.

368 No original: "En otros términos, no existiría una diferencia por 'naturaleza' entre las dos obligaciones, sino sólo una diferencia de régimen. En la critica contemporánea a la distinción, se sigue el método comparativo entre los dos regímenes, tratando de atenuar sus diferencias" (Guido Alpa, Responsabilidad civil y daño. Lineamentos y cuestiones, cit., p. 28).

"A boa-fé objetiva permeia-se por todo o direito positivo, e não apenas no campo contratual, independentemente de sua expressa menção em determinado dispositivo legal (art. 422 do Código Civil). No direito brasileiro, como demonstra o art. 187 do novo Código Civil, o exercício de todo direito subjetivo está condicionado à observância da boa-fé objetiva, que, assim, protege outras posições jurídicas que não as contratuais" (Cristiano de Souza Zanetti, Responsabilidade pela ruptura das negociações, cit., p. 55). 
Será, todavia, a partir de uma base fundada eminentemente pela confiança depositada na pessoa que prestou informações, aconselhou ou recomendou ao destinatário que se desencadeará a discussão acerca dos efeitos produzidos pela respectiva informação, conselho ou recomendação.

De fato, como se verá a seguir, entendemos que a determinação da responsabilidade por conselhos, informações ou recomendações prestados na fase précontratual dependerá dos fatos que lhe deram origem, assim como das relações entre os negociantes e dos negociantes com terceiros, podendo ensejar a imputação da responsabilidade contratual ou da extracontratual, o que não significa a exclusão da base valorativa formada pela confiança e pela boa-fé, consoante restará demonstrado

\subsubsection{A responsabilidade pela informação, o conselho e a recomendação, na fase pré- contratual}

No momento de aproximação das partes e de tentativa de regulamentação de seus interesses torna-se imperiosa a troca de informações, que pode levar ou não à concretização do negócio. Sabe-se que, em outras ocasiões, referidas negociações não chegam a ocorrer, posto tratar-se de contratos de pequeno valor e de execução imediata, como a compra e venda de uma barra de chocolate em uma padaria ou de contratos de adesão, quando as condições contratuais são impostas por apenas uma das partes, hipóteses em que o aderente não tem como negociar os seus termos, cabendo-lhe, apenas, submeter-se às imposições da contraparte, como ocorre, essencialmente, nas relações de consumo, em que os detentores do poder econômico impõem a sua vontade através dos chamados "contratos standard".370

\footnotetext{
370 "Muitas vezes a conclusão do contrato não representa o êxito de negociações verdadeiras e próprias, de uma discussão livre e paritária entre os contraentes sobre cada uma das cláusulas, mas é antes o fruto de uma imposição unilateral de um contrato pré-fixado antecipadamente por uma parte geralmente sob a forma de modelo impresso - à outra parte, que se limita a aceitá-lo, sem o discutir e até mesmo sem conhecer bem o seu conteúdo. Isto acontece, sobretudo, nas relações entre empresas e consumidores, tendo por objecto a prestação de bens e de serviços 'de massa', e dá o lugar ao fenômeno do "contratos standards"” (Enzo Roppo, O contrato, cit., p. 105-106).
} 
No entanto, mesmo nessas hipóteses em que uma das partes não possui condições de discutir os termos e condições do negócio, ${ }^{371}$ restando-lhe apenas aderir ou não ao modelo que lhe está sendo imposto, persiste a importância da informação para a celebração do acordo. O mesmo se pode dizer acerca da relevância de uma recomendação ou de um conselho prestados no momento em que o aderente está para celebrar o contrato e que podem ser vitais para a confirmação de sua vontade ou para uma alteração de planos que faça com que o negócio não seja concluído.

Deste modo, seja nos contratos paritários, seja nos contratos de adesão, releva-se a importância do aconselhar, recomendar e informar na fase pré-contratual, o que leva a perquirir sobre as consequências de uma abrupta ruptura das negociações que resulte em frustração daquela expectativa criada pelo conselho ou pela recomendação, ou pela inexatidão de uma informação essencial para a conclusão do pacto.

Como exemplo, pensemos na hipótese de um vendedor de automóveis que recomenda vivamente a aquisição de um veículo seminovo para um interessado que reside em cidade bastante distante, convencendo-o a se deslocar até a sua loja, para lá verificar que as informações prestadas no momento das negociações eram inverídicas e que o estado do bem em questão é diametralmente oposto daquele informado anteriormente. Seria possível pleitear uma indenização do dono da loja para cobrir as despesas referentes ao custeio da viagem, bem como pelo tempo perdido pelo interessado na aquisição do automóvel? $?^{372}$

371 Cristiano de Sousa Zanetti lembra também de outro pacto em que há menor margem para negociação, o chamado contrato compulsório, "caracterizado pela supressão da liberdade de uma das partes em celebrar o negócio jurídico. No direito brasileiro, a figura encontra expressa previsão no art. 73 da Lei n. 9.472/97 e na Resolução Conjunta n. 1/99 da Agência Nacional de Telecomunicações - Anatel, da Agência Nacional de Energia Elétrica - Aneel - e da Agência Nacional de Petróleo - ANP, que obrigam o titular de infra-estrutura de telecomunicações, energia elétrica ou petróleo a dividi-lo com outra empresa que seja concessionária de serviço público e pretenda utilizá-lo, com o objetivo de minimizar o impacto decorrente das instalações necessárias à satisfação das necessidades da comunidade" (Responsabilidade pela ruptura das negociações, São Paulo: Juarez de Oliveira, 2005, p. 7).

372 "Reparação de danos materiais e morais. Princípio da boa fé objetiva dos contratos. Negociações preliminares a induzir os autores a deslocarem-se até o Rio de Janeiro para a aquisição de veículo 'semi-novo' da ré, na companhia de seu filho ainda bebê, gerando despesas. Deslealdade nas informações prestadas, pois oferecido como 'uma jóia de carro', 'impecável', gerando falsas expectativas, pois na verdade o veículo apresentava pintura mal feita, a revelar envolvimento em acidente de trânsito. Omissão no fornecimento do histórico do veículo que poderia confirmar as 
Ou o caso de um gerente de banco que aconselha a sua cliente, uma octogenária aposentada, sem nenhuma intimidade com o mercado financeiro, a retirar as suas economias da poupança e aplicá-las em um investimento de altíssimo risco, sem alertá-la dos perigos que envolvem essa operação, mas visando a apenas atingir a meta mensal imposta por seus superiores. Haveria, neste caso, a possibilidade de se pleitear uma indenização da instituição bancária, em virtude das ações praticadas por seu empregado em momento anterior à conclusão do contrato?

Nestas hipóteses, ganha relevo a discussão acerca da conduta desleal e antiética do responsável pela informação, conselho ou recomendação, em um momento anterior à conclusão do contrato, e, especialmente, sobre a possibilidade de responsabilizá-lo pelos danos decorrentes de suas ações ou omissões.

Todavia, mesmo nas situações em que o conselho, a recomendação ou a informação não estejam eivados pelo dolo daquele que os transmitiu é possível que causem dano ao seu destinatário, decorrente da frustração de uma justa expectativa, o que poderá gerar o dever de repará-lo.

Imagine-se, por exemplo, uma pessoa que, negociando com um agente de investimentos, desiste de contratá-lo quando recebe uma informação equivocada acerca da alíquota do imposto incidente sobre determinado investimento, para, meses depois, descobrir que sobre referida aplicação não incidiria nenhuma espécie de tributo. Poderia pleitear uma indenização em decorrência da ruptura indevida da negociação e da perda da chance de lucrar com os juros decorrentes da aplicação em questão?

Em todos os exemplos supramencionados encontra-se latente a questão atinente à responsabilidade pré-contratual decorrente da conduta de quaisquer das partes ou de terceiros, em um momento que antecede a conclusão do contrato. Trata-se da

suspeitas de tratar-se de veículo batido. Danos materiais, relativos às passagens aéreas e estadia e danos morais decorrentes do sentimento de desamparo, frustração e revolta diante da proposta enganosa formulada. Sentença confirmada por seus próprios fundamentos" (TJRS, RInom 71000531376, Porto Alegre, 2. ${ }^{a}$ Turma Recursal Cível, rel. Des. Ricardo Torres Hermann, j. 08.09.2004). 
responsabilidade por ações ou omissões ocorridas em período anterior à celebração da avença e que acabam por causar danos à outra parte.

Nesses casos deve-se perquirir sobre a possibilidade de se reparar o dano decorrente da informação, conselho ou recomendação antes da conclusão do acordo de vontades, ainda que não tenha havido dolo de seu responsável, o que ressalta a importância de se analisar o tema atinente à responsabilidade pré-contratual.

Na busca pelo equilíbrio entre a liberdade de contratar e, por conseguinte, de retirar-se das negociações sem ser forçado à celebração do acordo, e a tutela da justa expectativa de um dos negociantes, lesado em virtude da brusca e injustificada retirada da contraparte, é onde reside a complexidade da responsabilidade pré-contratual.

Para Enzo Roppo esse ponto de equilíbrio deve ser encontrado na regra segundo a qual "a ruptura das negociações gera responsabilidade apenas quando é injustificada e arbitrária e não já quando é apoiada em uma justa causa que a torne legítimo exercício de uma liberdade econômica". 373

Partilhamos desse entendimento, que demonstra a relevância da confiança e da boa-fé objetiva para a solução das questões decorrentes da responsabilidade précontratual. $^{374}$

Entretanto, como ressalvamos em diversos momentos de nosso trabalho, não se deve simplesmente afirmar que às negociações preliminares aplica-se o princípio da boa-fé objetiva, de forma generalizante e sem nenhuma preocupação metodológica, a fim de evitar um alargamento incontrolado de sua amplitude, em virtude do extenso rol de situações em que se pode apreciar a responsabilidade pré-contratual.

\footnotetext{
373 Enzo Roppo, O contrato, cit., p. 107.

374 Assim ensina Antonio Junqueira de Azevedo: "É preciso que, na fase pré-contratual, os candidatos a contratantes ajam, nas negociações preliminares e na declaração da oferta, com lealdade recíproca, dando as informações necessárias, evitando criar expectativas que sabem destinadas ao fracasso, impedindo a revelação de dados obtidos em confiança, não realizando rupturas abruptas e inesperadas das conversações etc.” (Responsabilidade pré-contratual no Código de Defesa do Consumidor: estudo comparativo com a responsabilidade pré-contratual no direito comum, cit., p. 25-26).
} 
Neste sentido, Menezes Cordeiro adverte para o perigo de se afirmar que, na fase pré-contratual, as partes deveriam "usar de correção ou de boa-fé sem que tais conceitos indeterminados sejam dotados de bases mínimas para sua concretização". ${ }^{375}$

Porém, até mesmo na hipótese de uma das partes não ter se retirado das negociações e, por conseguinte, de o contrato ter sido celebrado, é possível que haja dano decorrente das ações de um dos sujeitos na fase de tratativas, em virtude da extensa amplitude da responsabilidade pré-contratual.

Com efeito, diversas são as vertentes decorrentes das negociações preliminares, desde uma simples troca de informações incapaz de levar o negócio adiante por absoluta falta de interesse dos negociantes até um amplo debate envolvendo os riscos do negócio e os seus efeitos patrimoniais e pessoais, por exemplo. ${ }^{376}$

Além disso, é possível que os danos resultantes das negociações decorram de ações de terceiros ${ }^{377}$ em um alargamento da ideia de confiança nas relações précontratuais.

Neste diapasão, observa Carneiro da Frada que a relação pré-contratual, originariamente vista como uma ligação adstrita aos sujeitos da relação contratual,

375 António Manuel da Rocha e Menezes Cordeiro, Tratado de direito civil português. Parte geral, cit., p. 504.

376 "É de reconhecer à culpa in contrahendo uma multiplicidade de desempenhos. Eles vão desde a controversa proteção das pessoas e patrimônio das partes envolvidas contra ingerências danosas mútuas até finalidades mais pacíficas do instituto, como a de possibilitar uma adequada circulação da informação entre os sujeitos com vista a uma contratação mais consciente ou segura; respondem igualmente, desde à necessidade de ordenar adequadamente os riscos patrimoniais específicos que a atividade negociatória implica, designadamente perante a possibilidade de um fracasso do processo negocial, até a conveniência da tutela da parte mais fraca, prevenindo e sancionando um iter negocial potencialmente gerador de desequilíbrios e injustiças" (Manuel Antonio de Castro Portugal Carneiro da Frada, Teoria da confiança e responsabilidade civil, cit., p. 113).

377 Para distinguir parte e terceiro servimo-nos dos ensinamentos de Enzo Roppo, para quem "o conceito de parte no contrato não coincide com o conceito de pessoa (física ou jurídica). Parte significa centro de interesses objetivamente homogêneos, e uma parte contratual pode consistir em uma, como em duas, três ou mais pessoas (que relativamente àquele contrato exprimem uma posição de interesse comum)". Mais adiante, explica o emérito jurista italiano que "à noção de parte do contrato, contrapõe-se à de terceiro: são terceiros em relação ao contrato, todos os sujeitos que não são partes e que, no entanto, nele podem estar de qualquer forma interessados ou são atingidos indiretamente pelos seus efeitos" ( $O$ contrato, cit., p. 81-82). 
estende-se para abranger outras pessoas que, de alguma forma, estejam envolvidas na “teia de negociações" ou sejam próximas de alguma das partes. ${ }^{378}$

Segundo seus ensinamentos, duas são as linhas de argumentação que visam à fundamentação da responsabilidade de terceiros por danos causados na fase précontratual: uma primeira, em que o terceiro "introduzido nas negociações por uma das partes, influenciou de modo determinante a conclusão do contrato ao concitar a confiança da outra". 379

Como exemplo, particularmente voltado ao tema objeto deste trabalho, imagine-se um arquiteto que aconselha o dono da obra a adquirir um determinado piso de madeira para instalar em sua cozinha, somente para auxiliar a outra parte contratante - seu amigo e dono da loja de pisos de madeira -, quando sabidamente não seria o mais adequado para o cômodo em questão. Seria possível ao dono da obra pretender que o arquiteto reparasse os danos decorrentes dessa danosa escolha?

Cremos que sim, eis que a decisão do dono da obra foi tomada em razão de acreditar firmemente no conselho do arquiteto, em virtude da confiança que lhe foi inculcada pelo profissional responsável por sua realização.

De outro modo, uma segunda linha de argumentação consistiria em uma relação de proximidade entre o terceiro e o negócio em formação e discussão, de forma que se pudesse afirmar que estivesse economicamente interessado na conclusão do contrato ou procurasse através do pacto a obtenção de um proveito próprio. ${ }^{380}$

Como exemplo, pensemos em uma pessoa que pretende investir parte de suas economias na bolsa de valores e recebe a proposta de dois corretores interessados em administrar seu capital. Premida pela dúvida sobre qual profissional deve ser

\footnotetext{
378 Manuel Antonio de Castro Portugal Carneiro da Frada, Teoria da confiança e responsabilidade civil, cit., p. 113.

379 Idem, ibidem, p. 118.

380 Manuel Antonio de Castro Portugal Carneiro da Frada, Teoria da confiança e responsabilidade civil, cit., p. 118.
} 
contratado, essa pessoa pede ajuda a um amigo que trabalha na mesma área, a fim de ouvir uma opinião mais abalizada sobre o assunto. No entanto, esse amigo recomenda a contratação de um dos profissionais em virtude da possibilidade de receber uma comissão considerável, prometida em razão da indicação, não obstante ter ciência do fato de que a corretora em que esse profissional trabalha se encontra à beira da insolvência. Como consequência, o profissional indicado pelo amigo foi contratado devido a sua entusiasmada recomendação. Neste caso, haveria como responsabilizar o amigo que agiu dolosamente, posto que a insolvência da corretora se concretizou tão logo o investidor celebrou o contrato com o corretor indicado, fazendo com que perdesse todas as suas economias?

Em nossa opinião, a resposta pode ser positiva, desde que comprovada a atitude dolosa perpetrada pelo amigo do investidor, decorrente de seu interesse econômico na contratação do profissional, além do nexo de causalidade entre a escolha do corretor por ele indicado e a recomendação recebida.

Em ambos os exemplos apresentados é possível verificar que a confiança constituiu o fundamento básico para levar uma das partes à contratação potencialmente danosa, aliada ao interesse econômico do terceiro, no segundo caso, o que reforça a tese aqui defendida acerca da existência de uma responsabilidade pela confiança.

Nessa última situação, em que existe uma terceira pessoa diretamente envolvida no processo negocial, muito embora não seja um dos contratantes, faz-se necessária a apuração de seus interesses, pois o terceiro que agiu em razão de suas próprias conveniências e acabou por prejudicar uma das partes, apenas para levá-la à celebração do contrato e tirar algum proveito dessa avença, deve responder pelos danos dolosamente causados.

Por outro lado, ainda que o terceiro tenha agido sem interesse algum, é possível que seja responsabilizado pelo dano causado a qualquer dos contratantes, a fim de não se permitir que a vítima permaneça indene, desde que fique comprovada a culpa no momento da transmissão da informação, do conselho ou da recomendação. Em 
ambos os casos, contudo, faz-se imperioso ponderar os interesses envolvidos na relação negocial, bem como a sua titularidade.

Todavia, afirmar que a responsabilidade do terceiro, alheio à relação contratual, decorre da culpa in contrahendo, significa vinculá-lo ao contrato e sujeitá-lo a uma convenção da qual não fez e não fará parte, o que leva a perquirir se é possível sujeitar alguém a responder por um dano decorrente de um vínculo contratual cujos direitos e deveres ali estabelecidos não lhe atingem. ${ }^{381}$

Com efeito, a responsabilidade do terceiro nos casos supracitados decorre de infração aos deveres de conduta ética e leal que compõem a base do ordenamento jurídico brasileiro hoje. ${ }^{382}$ Mas como fundamentá-la na responsabilidade contratual se não é parte contratante e, com relação a esse terceiro, não existe sequer um contrato?

Em algumas situações, terceiros possuem interesse nas tratativas, participando ativamente da relação negocial, como é o caso de peritos ou consultores que tenham atuado em momento anterior à celebração do contrato. Nestes casos é possível verificar a existência de um liame que vincule o terceiro ao contato principal, hipótese em que a sua responsabilidade poderia estar atrelada ao negócio a ser celebrado entre as partes ou até mesmo derivar de sua responsabilidade profissional.

Em outros casos, contudo, a solução passaria necessariamente pelo padrão de conduta adotado pelo terceiro, posto que inexistente qualquer vínculo contratual com as partes. Será nessas situações em que a responsabilidade pela confiança poderia

\footnotetext{
381 "Problemático é no entanto aceitar e justificar que a titularidade do interesse econômico prosseguido através de um contrato celebrado por outrem legitime por si a sujeição de alguém a um estatuto de deveres perante a outra parte no negócio como se ela própria fosse parte nesse mesmo contrato e estivesse vinculada por essa via aos direitos e deveres dela emergentes" (Manuel Antonio de Castro Portugal Carneiro da Frada, Teoria da confiança e responsabilidade civil, cit., p. 123).

382 "Embora o terceiro que não participe ou seja beneficiário da relação contratual a se formar, não possa ser confundido com a parte, que emite a declaração de vontade no momento da formação do contrato, é de se lembrar que, em virtude do princípio da relatividade, da cláusula geral de boa-fé e da função social do contrato, os conceitos de parte e terceiro também foram afetados, não estando mais unicamente atrelados ao consentimento; os terceiros não podem se comportar como se o contrato não existisse ou, ainda, de forma a prejudicar o inadimplemento do contrato, agindo, portanto, em desacordo com os deveres que emanam da boa-fé" (Mariana Pazianotto Deperon, Responsabilidade civil pela ruptura ilegítima das tratativas, cit., p. 27-28).
} 
constituir a solução adequada para o caso concreto desde que restasse caracterizada a violação ao dever de conduta ético imposto por nosso ordenamento com a consequente ocorrência de dano decorrente dos atos praticados por esse terceiro.

Como se vê, a partir da análise da atuação de terceiros em momento anterior à celebração do contrato ampliam-se as possibilidades de ocorrência de danos no momento da formação do pacto, multiplicando-se os inúmeros vetores da responsabilidade pré-contratual.

$\mathrm{Na}$ verdade, no período que antecede a celebração do contrato, das mais diversas são as questões potencialmente causadoras de danos, o que ultrapassa em muito o âmbito da negociação, fazendo com que os deveres das partes e de terceiros não se restrinjam aos limites do contrato a ser celebrado, para atingir dimensão muito mais ampla fundada na confiança e na boa-fé.

Essa expansão da responsabilidade pré-contratual torna latente o consequente alargamento de seu campo de incidência.

Sobre o tema, Ricardo Luís Lorenzetti salienta a expansão da responsabilidade pré-contratual nos tempos de hoje, ressalvando que o seu campo de abrangência abarca as hipóteses de defeitos na negociação, consistentes em enganos, erros, ocultação de informação que levam a um defeito na formação do contrato; retratação da oferta, quando se trata de uma declaração unilateral de vontade (oferta irrevogável ou submetida a prazo) e quando seja simples, mas tenha gerado uma expectativa na base pela qual a outra parte realizou gastos; encerramento arbitrário $e$ intempestivo das tratativas; descumprimento dos deveres pré-contratuais do empresário nos contratos de consumo; e danos a pessoas derivados de prestações précontratuais. ${ }^{383}$

383 No original: "La perspectiva se expandió notablemente en los tiempos actuales, abarcando los siguientes supuestos: Defectos en la negociación: se trata de engaños, errores, ocultamiento de información que llevan a un defecto en la formación del contrato (...). Retractación de la oferta cuando es una declaración unilateral de voluntad (oferta irrevocable o sometida a plazo) y cuando es simples pero ha generado una expectativa en base a la cual la otra parte realizó gastos. Apartamiento intempestivo y arbitrario de las tratativas. Incumplimiento de los deberes precontractuales del 
Neste contexto, António Menezes Cordeiro assinala as múltiplas possibilidades decorrentes da ruptura das tratativas. Assim, partindo de uma análise das decisões em que a culpa in contrahendo foi concretizada, separadas em distintos grupos de casos, chega à conclusão no sentido de prevalecer, em alguns casos, o dever de segurança, a ser providenciado pelas partes, a fim de que ninguém sofra danos decorrentes das negociações, sejam à saúde, à integridade física ou ao patrimônio. Por outro lado, também resulta da culpa in contrahendo o dever de informação précontratual capaz de tornar possível a circulação, entre as partes, de todas as informações necessárias à contratação. Além disso, sobressai o dever de lealdade, que se diferencia do dever de informação por não se resumir apenas a uma questão de comunicação, mas, antes de tudo, a um problema de atuação. ${ }^{384}$

Dessa forma, é possível verificar a importância da tutela da confiança no âmbito das tratativas negociais, em especial por se tratar de um momento em que ainda não existe um vínculo contratual, e que, por essa razão, permite a qualquer das partes exercer o seu direito de retirar-se das negociações.

Contudo, para chegar a uma solução acerca da responsabilidade pelos conselhos, informações e recomendações na fase pré-contratual, deve-se efetuar a devida ponderação entre a necessidade de tutelar a confiança e a de garantir a autonomia da vontade, preservando-se a liberdade individual, sem premiar condutas inidôneas e iníquas.

Tudo isso deve ser realizado de acordo com as regulações específicas de nosso sistema jurídico, mantendo-se, destarte, estreita correlação com o conteúdo normativo do ordenamento pátrio e remetendo-se a solução para os seus valores, princípios, regras e padrões, assim como para os regimes relacionados à responsabilidade extracontratual e contratual dispostos pelo Código Civil.

empresario en los contratos de consumo. Daños a la persona derivados de prestaciones precontractuales (Ricardo Luis Lorenzetti, Tratado de los contratos: parte general, cit., p. 309).

384 António Manuel da Rocha e Menezes Cordeiro, Tratado de direito civil português. Parte geral, cit., p. 504-507. 
Feita essa premissa, entendemos que, havendo danos à pessoa na fase précontratual, a solução será a aplicação do regime atinente à responsabilidade extracontratual, de acordo com o art. $927^{385}$ e seguintes de nosso Código Civil. Nesses casos existe um claro dever de segurança imposto às partes, no sentido de evitar que das tratativas resultem danos aos negociantes.

No entanto, se os danos causados na fase pré-contratual decorrerem de uma relação de consumo, aplicar-se-á o Código de Defesa do Consumidor, cujo regime não está assentado na dicotomia entre a responsabilidade contratual e a extracontratual, mas primordialmente na existência de um dever de proteção e de segurança para o consumidor e fundado no princípio da boa-fé objetiva, expressamente previsto pelos arts. $4^{\circ}$, inc. III, ${ }^{386}$ e 51 , inc. IV ${ }^{387}$ da Lei 8.078/90.

Além disso, frequentes são as situações em que existe dolo de um dos negociantes ou de ambos. Nessas hipóteses, a solução não pode decorrer de uma análise perfunctória dos fatos, mas demanda um estudo mais aprofundado do caso concreto.

De fato, se a atitude dolosa teve por intuito a celebração do negócio e acabou por lograr o seu intento, para, posteriormente, verificar-se a sua anulação, entendemos existir responsabilidade por parte daquele que agiu com dolo e causou dano à contraparte.

385 “Art. 927. Aquele que, por ato ilícito (arts. 186 e 187), causar dano a outrem, fica obrigado a reparálo. Parágrafo único. Haverá obrigação de reparar o dano, independentemente de culpa, nos casos especificados em lei, ou quando a atividade normalmente desenvolvida pelo autor do dano implicar, por sua natureza, risco para os direitos de outrem."

386 “Art. 4. ${ }^{\circ}$ A Política Nacional das Relações de Consumo tem por objetivo o atendimento das necessidades dos consumidores, o respeito à sua dignidade, saúde e segurança, a proteção de seus interesses econômicos, a melhoria da sua qualidade de vida, bem como a transparência e harmonia das relações de consumo, atendidos os seguintes princípios: (...) III - harmonização dos interesses dos participantes das relações de consumo e compatibilização da proteção do consumidor com a necessidade de desenvolvimento econômico e tecnológico, de modo a viabilizar os princípios nos quais se funda a ordem econômica (artigo 170, da Constituição Federal), sempre com base na boa-fé e equilíbrio nas relações entre consumidores e fornecedores."

387 “Art. 51. São nulas de pleno direito, entre outras, as cláusulas contratuais relativas ao fornecimento de produtos e serviços que: (...) IV - estabeleçam obrigações consideradas iníquas, abusivas, que coloquem o consumidor em desvantagem exagerada, ou sejam incompatíveis com a boa-fé ou a eqüidade." 
Isso porque o agente doloso incutiu na contraparte a confiança de que o negócio celebrado seria válido, devendo responder por sua conduta desleal e pela consequente quebra dessa relação de confiança. Neste caso, o culpado deveria responder pela violação do dever de lealdade e, em razão de o vínculo contratual ter se efetivado, o regime contratual do Código Civil seria o adequado para preservar os interesses da parte lesada.

Assim, entendemos que, embora a violação da confiança tenha ocorrido no curso do processo obrigacional que deu origem à conclusão do contrato, é certo que o vínculo contratual se efetivou, razão pela qual o agente doloso possui o dever de reparar os danos causados pela violação das expectativas do lesado, fundamento da responsabilidade pela confiança, que se concretizará, nessa hipótese, pelo regime contratual disposto nos arts. $389^{388}$ e seguintes do Código Civil.

Como exemplo, cite-se a hipótese de o proprietário de um apartamento destinado à locação informar dolosamente ao pretenso inquilino que reparou toda a parte hidráulica do imóvel apenas para lograr a celebração do contrato, levando a contraparte a assinar o instrumento unicamente em razão dessa informação. Passados trinta dias da imissão na posse do locatário ocorre uma ruptura da coluna de esgoto do referido apartamento, em decorrência da falta de manutenção, exclusivamente, tornando o imóvel inabitável. Esse fato, além de permitir a anulação do contrato por dolo, autoriza uma pretensão indenizatória por parte do locatário em razão da violação do dever de lealdade e de informação pelo locador.

Cabe ressaltar que a sanção imposta ao locador não decorre da intenção de lesar o locatário nem do erro provocado ao inquilino, mas da violação do dever de lealdade e de informação, assim como das justas expectativas do lesado, o que afronta a boa-fé objetiva, caracterizando-se a antijuridicidade e dando ensejo à reparação do dano através da responsabilidade pela confiança, mas no regime contratual dos arts. 389 e seguintes do Código Civil.

\footnotetext{
388 “Art. 389. Não cumprida a obrigação, responde o devedor por perdas e danos, mais juros e atualização monetária segundo índices oficiais regularmente estabelecidos, e honorários de advogado."
} 
Em outra hipótese, todavia, a ação dolosa decorre da retirada abrupta e intempestiva das negociações, que venha a causar dano ao outro negociante. Nesse caso, uma vez caracterizada a violação ao dever de lealdade negocial, resta caracterizada a antijuridicidade no exercício do direito de recesso, o que impõe o dever de reparar os danos daí decorrentes.

Mais uma vez, está-se diante do fundamento da responsabilidade pela confiança. Porém, há que se ressaltar que o julgador deve ser bastante criterioso na análise da conduta da parte que se retirou das tratativas, a fim de buscar a comprovação inequívoca do dolo do retirante, levando-se em consideração a autonomia da vontade e a tutela da liberdade que, neste caso, consistiria na liberdade de escolha para contratar ou não.

De fato, já dissemos que não se pretende com a presente tese aniquilar a autonomia da vontade nem a liberdade, posto tratarem-se de expressão máxima da individualidade e a sua tutela constituir diretriz fundamental de uma ordem jurídica justa.

No entanto, o exercício do direito de liberdade, assim como da autonomia da vontade, não é absoluto e deve se efetivar em respeito às normas da convivência social, à boa-fé e aos bons costumes, essenciais para a vida em sociedade.

Este é o ensinamento de Menezes Cordeiro ao analisar a aproximação feita entre a culpa in contrahendo e a boa-fé, revelando dois vetores da segunda que se destacam quando se trata das negociações preliminares: a tutela da confiança e a primazia da materialidade subjacente. Assim, não devem as partes, na fase de preparação dos contratos, suscitar situações de confiança que venham a frustrar posteriormente. De outro modo, por primazia da materialidade subjacente, deve-se entender que a autonomia privada faculta às partes negociar seus contratos livremente $\mathrm{e}$ interromper essas negociações quando bem entenderem, o que significa um valor a se aproveitar com esse sentido material de busca por um livre consenso, e não apenas de uma conformidade exterior com o direito, fazendo com que as negociações emulativas, 
chicaneiras, dilatórias ou de qualquer outro título sejam estranhas à autonomia privada e à boa-fé. ${ }^{389}$

Por conseguinte, faz-se imperiosa a ponderação entre os interesses daquele que se retirou das negociações preliminares e os da pessoa que se julga lesada por essa retirada, a fim de não se deixar uma vítima de dano sem a sua devida reparação, mas também não se permitir que uma pessoa acabe por suportar injustamente o ônus de uma indenização apenas para que se privilegiem os interesses da vítima.

É nesse momento que entra a confiança e a sua concretização no sistema através da boa-fé objetiva, como parâmetros de conduta a servir de alicerce necessário para as decisões do julgador, imputando deveres de lealdade, de informação e esclarecimento, bem como de proteção.

Neste sentido ressalva Pedro Paes de Vasconcelos que os deveres de boa-fé na fase das negociações são tipificados em deveres de proteção, deveres de esclarecimento e deveres de lealdade. Por deveres de proteção se entende aqueles que vinculam as pessoas que se encontram em tratativas a fazer o que estiver ao seu alcance, razoavelmente, para evitar ou reduzir danos ou custos da outra parte. Já os deveres de esclarecimento vinculam as partes em negociação a partilhar dados e informações relevantes para a correta apreciação das circunstâncias do contrato, assim como acerca da qualidade das pessoas envolvidas, para que se possibilite a adequada avaliação dos bens que possuam relevância na equação econômica do contrato. Por deveres de lealdade deve-se entender aqueles que vinculam as partes em tratativas a comportar-se na interação contratual com honestidade e correção. Esses últimos deveres, de lealdade, possuem grande amplitude, compreendendo até mesmo os deveres de proteção e esclarecimento, que não deixam de ser típicas concretizações de lealdade. ${ }^{390}$

389 António Manuel da Rocha e Menezes Cordeiro, Tratado de direito civil português. Parte geral, cit., p. 507.

390 Pedro Paes de Vasconcelos, Teoria geral do direito civil, cit., p. 491-492. 
Destarte, o valor atinente à confiança é fundamental para a solução dos problemas decorrentes da ruptura das tratativas, concretizado pela boa-fé que normativiza os fatos que constituirão a fonte de referidos deveres de conduta. ${ }^{391}$

Assim, em virtude da incomensurável amplitude de fatos que podem dar origem à violação dos deveres de conduta na fase pré-contratual e da já citada diversidade de vetores que podem ensejar a necessária reparação de danos ocorridos em fase anterior à celebração do contrato, evidencia-se que a divisão da responsabilidade em dois regimes, um contratual e outro delitual, demonstra-se insuficiente para solucionar a plêiade de questões daí decorrentes, o que reforça a ideia de que a fronteira entre os dois regimes se encontra cada vez mais diluída, tornando imperiosa a necessidade de se recorrer ao fundamento da responsabilidade civil para a solução dos inúmeros problemas que possam ocorrer na fase das tratativas negociais.

De fato, nos dias de hoje as relações entre sujeitos alcançam tamanha complexidade e dimensão que fica difícil reduzi-las a um campo estritamente delimitado pelo terreno do contrato e o do delito, de forma que a linha fronteiriça entre essas duas áreas se demonstra cada vez mais etérea, às vezes até mesmo inexistente, como na hipótese de atuação de terceiros no período pré-contratual.

391 “A boa-fé apenas normativiza certos fatos que, esses sim, são fonte: mantenha-se o paralelo com a fenomenologia da eficácia negocial: a sua fonte reside não só na norma que mande respeitar os negócios, mas no próprio negócio em si. A enumeração dos fatos-fonte dos deveres de atuar de boafé resulta dos estudos efetuados: o início de negociações preliminares, a existência de um contrato, ou da sua aparência, a conexão de terceiro com uma obrigação ou o desaparecimento de um negócio. Todos eles têm em comum a verificação de um relacionar entre duas ou mais pessoas, através de uma dinâmica que pressupõe uma conjugação de esforços que transcende o estrito âmbito individual. O Direito obriga, então, a que, nessas circunstâncias, as pessoas não se desviem dos propósitos que, em ponderação social, emerjam da situação em que se achem colocadas: não devem assumir comportamentos que a contradigam - deveres de lealdade - nem calar ou falsear a atividade intelectual externa que informa a convivência humana - deveres de informação. Embora as estruturas e teleologia básicas sejam as mesmas, adivinha-se a presença de concretizações diversas, consoante os fatos que lhes dêem origem. Na constância de um contrato, o dever de informação poderá ser mais intenso do que in contrahendo ou post pactum finitum. Mas nesta base, não se alcança a materialidade desta fenomenologia. O contrato é fonte efetiva dos deveres contratuais; no entanto, para efeitos de aplicação da boa-fé - art. 762.\%/2 - ele funciona como mero fato jurídico em sentido estrito. Daí que, por hipótese em negociações delicadas, os deveres de lealdade e informação possam ser bem mais intensos do que na vigência de um contrato comum. Os critérios para a determinação material dos deveres de comportamento devem ser procurados noutras latitudes" (António Manuel da Rocha e Menezes Cordeiro, Da boa-fé objetiva no direito civil, cit., p. 650-651). 
Essa complexidade das relações privadas demanda a existência de alguns mecanismos capazes de fomentar a sua redução, a fim de permitir que as pessoas encontrem uma base minimamente segura capaz de permitir que se relacionem ou até mesmo que saiam de casa ao raiar do dia.

Nesse contexto exsurge a confiança como valor fundamental e mecanismo de redução dessa complexidade característica da ordem social e enquanto fonte da obrigação de reparar os danos decorrentes da violação do dever ético de conduta imposto por nosso ordenamento. Isso porque, consoante já dito anteriormente, impõe-se ao direito a sua tutela como um dos fundamentos éticos e morais essenciais ao convívio social. $^{392}$

Como consequência, pode-se afirmar que até mesmo a retirada culposa das negociações pode gerar o dever de indenizar, desde que caracterizada a antijuridicidade da conduta do retirante, através da violação da confiança da contraparte, analisada não em razão de critérios subjetivos, mas através de critérios objetivos determinados pelos deveres de conduta supramencionados.

Tanto nos casos de ocorrência de dolo daquele que se retira abruptamente da negociação como nos casos que decorrem de uma conduta culposa de sua parte, verifica-se a hipótese de cabimento da responsabilidade subjetiva, eis que necessária a prova da culpa (lato sensu) do agente causador do dano.

Nestes casos, de ruptura ilegítima das tratativas, entendemos que o regime a ser aplicado será o da responsabilidade extracontratual, nos termos do art. 927 e seguintes do Código Civil, eis que não se concretizou o vínculo contratual.

Pode parecer um contrassenso a defesa da tese de que a anulação de um contrato por ação dolosa de uma das partes, na fase das negociações preliminares, leve à

\footnotetext{
392 Nesse diapasão, ressalva Anderson Schreiber que a inserção da confiança no amplo movimento de solidarização do direito "vem justamente valorizar a dimensão social do exercício dos direitos, ou seja, o reflexo das condutas individuais sobre terceiros" (A proibição de comportamento contraditório. Tutela da confiança e venire contra factum proprium, cit., p. 94).
} 
reparação do dano pelo regime da responsabilidade contratual, ao passo que a responsabilidade pela ruptura indevida das tratativas é considerada extracontratual.

Justificamos o nosso entendimento na existência do vínculo contratual no primeiro caso, o que demonstra a consolidação do processo obrigacional de formação e conclusão do contrato. Deste modo, verifica-se que este se iniciou através das negociações, mas logrou chegar à celebração do negócio e à formação do vínculo, para, posteriormente ser anulado.

Há que se fixar um parâmetro para que o regime contratual se inicie e entendemos que ele se constitui com a formação do vínculo contratual, lembrando que a proposta já vincula o proponente nos termos do art. $427^{393}$ do Código Civil.

Destarte, faz-se necessário a aplicação do regime contratual, até para que se possa proteger a parte lesada, a fim de se evitar, inclusive, o decurso do prazo prescricional de três anos para a reparação do dano extracontratual, enquanto que o prazo decadencial para a ação anulatória do contrato por dolo é de quatro anos.

Assim, seria possível chegar a uma situação iníqua e dissociada do sistema se a ação anulatória fosse ajuizada, por exemplo, após três anos e meio do fato, ainda dentro do prazo decadencial do art. $171,{ }^{394}$ mas já decorrido o prazo prescricional para a propositura da ação de reparação de danos do art. 205, § 3. ${ }^{\circ}, \mathrm{V},{ }^{395}$ ambos do Código Civil. Sendo contratual o regime adotado, o dano estaria caracterizado pelos efeitos lesivos da anulação do contrato, momento em que passaria a fluir o prazo prescricional.

Além disso, deve-se ressaltar que o ato anulável produz efeitos até a sua anulação, fazendo com que o contrato em questão produza eficácia até o momento em

\footnotetext{
393 "Art. 427. A proposta de contrato obriga o proponente, se o contrário não resultar dos termos dela, da natureza do negócio, ou das circunstâncias do caso."

394 “Art. 178. É de quatro anos o prazo de decadência para pleitear-se a anulação do negócio jurídico, contado: I - no caso de coação, do dia em que ela cessar; II - no de erro, dolo, fraude contra credores, estado de perigo ou lesão, do dia em que se realizou o negócio jurídico; III - no de atos de incapazes, do dia em que cessar a incapacidade."

395 “Art. 206. Prescreve: (...) $§ 3 .^{\circ}$ Em três anos: (...) V - a pretensão de reparação civil.”
} 
que for anulado, reforçando-se a tese de aplicação do regime contratual de responsabilidade.

Ademais, nessa hipótese existe um vínculo contratual que recebe proteção diferenciada do legislador em razão do regime dicotômico instituído em nosso Código Civil, o que faz com que o peso da relação contratual seja superior ao das negociações preliminares para o legislador. ${ }^{396}$

Quid iuris se a atitude dolosa levasse à nulidade do contrato? Nesse caso, o vínculo contratual não chega a se concretizar, eis que o nulo não convalesce nem é passível de ratificação pelas partes.

Assim, não havendo vínculo contratual, a responsabilidade será aquiliana. Contudo, o dano decorre dos efeitos lesivos da declaração da nulidade e não do ato doloso, pois não se pretende a anulação do contrato por vício do consentimento, mas sim a declaração de sua nulidade por algum outro motivo que acarrete a invalidação do negócio. O prazo prescricional de três anos passará a fluir desse momento, portanto.

Outrossim, há que se ressaltar que a responsabilidade pela ruptura das negociações poderá ser objetiva, uma vez caracterizado o abuso de direito por parte de qualquer um dos negociantes.

Assim ensina Sergio Cavalieri Filho ao afirmar que a concepção adotada pelo art. 187 do Código Civil é a objetiva, posto não ser necessária a consciência de se

396 Neste sentido é o entendimento de Caio Mário da Silva Pereira, para quem "a violação pela ruptura das negociações, a mais polêmica, surge quando um dos contraentes viola o dever de lealdade e correção e, após incutir no outro a confiança de que o contrato será celebrado rompe injustificadamente as negociações, vindo a lhe causar danos. Esta responsabilidade tem caráter excepcional (Serpa Lopes, Carrara), e não pode ser transposta para fora dos limites razoáveis de sua caracterização, sob pena de chegar-se ao absurdo jurídico de equiparar em força obrigatória o contrato e as negociações preliminares, e a admitir a existência de uma obrigação de celebrar o contrato em razão da existência pura e simples de negociações" (Instituições de direito civil: Contratos. Declaração unilateral de vontade. Responsabilidade civil, cit., p. 33). 
estar excedendo os limites impostos pela boa-fé, pelos bons costumes ou pelos fins econômicos e sociais do ordenamento, quando do exercício do direito. ${ }^{397}$

Por conseguinte, é possível concluir que o exercício do direito de recesso é garantido ao negociante, a qualquer tempo, desde que respeitada a confiança da contraparte e realizado de forma leal.

Entretanto, aquele que exceder manifestamente esse direito responderá pela conduta abusiva, independentemente da prova da culpa, nos termos do art. 187 de nosso Código Civil e a responsabilidade será aquiliana, em virtude da inexistência do vínculo contratual.

Por outro lado, também se faz necessário perquirir acerca da participação direta ou indireta de terceiros nas negociações preliminares e as consequências dos efeitos danosos daí decorrentes.

De fato, é cediço que em algumas negociações, muito complexas, terceiros são contratados para assistir os negociantes nesse processo, seja na qualidade de peritos ou de auditores, ou até mesmo para avalizar a seriedade e honradez de uma das partes.

Como exemplo, podemos citar o trabalho de diversos escritórios de advocacia, conhecidos como due diligences, que prestam serviços de auditoria fiscal, empresarial e trabalhista a seus clientes, sociedades empresárias envolvidas em processos de aquisição, fusão ou incorporação de outras empresas.

Nestes casos existe uma incessante troca de informações, enquanto transmissão de simples fatos, sem o objetivo de convencimento ou o conteúdo de um parecer propriamente dito, envolvendo um conselho ou recomendação.

397 Sérgio Cavalieri Filho, Programa de responsabilidade civil, cit., p. 143. Neste mesmo sentido é o Enunciado n. 37 da Primeira Jornada de Direito Civil promovida pelo Centro de Estudos do Conselho da Justiça Federal (Brasília/2002): "A responsabilidade civil decorrente do abuso do direito independe de culpa, e fundamenta-se somente no critério objetivo-finalístico". 
Porém, o final desse processo demanda um parecer exarado pelo escritório de advocacia, aconselhando ou não a realização do negócio; recomendando a manutenção de determinados funcionários, a contratação de outros ou a redução da folha de pagamento, com o consequente corte do número de empregados; direcionando, enfim, as ações do cliente no sentido da conclusão ou não da avença.

Existe por óbvio uma relação contratual entre o escritório de advocacia e seu cliente, cujo objeto consiste exatamente na prestação de informações, conselhos e recomendações, na forma de substanciosos pareceres, que acarretará a responsabilidade contratual se causarem danos ao contratante, o que será analisado no item referente à responsabilidade decorrente das relações contratuais. ${ }^{398}$

Todavia, importa analisar os efeitos que esses pareceres produzirão na esfera jurídica do outro negociante, na hipótese de o negócio não ser concretizado em razão do parecer apresentado pelo escritório de advocacia em questão.

Ora, é fato que o cliente do escritório de advocacia pode deixar de realizar o negócio em virtude do parecer que lhe foi apresentado, exercendo legitimamente o seu direito de recesso, pois o ato negocial não lhe pareceu vantajoso ou é muito arriscado, chegando até mesmo a constituir um mau negócio, que deve ser evitado. Afinal, foi para isso que se realizou a due diligence.

Porém, a ruptura das tratativas pode decorrer de informações negligentemente prestadas pelo escritório de advocacia ou estar eivada de erro do profissional responsável pelo parecer. Pode ainda resultar de dolo do profissional, interessado, por exemplo, na celebração de um acordo com outra empresa e não com aquela que foi auditada.

Nestas hipóteses, não existe um contrato entre o negociante preterido e a firma de advocacia, razão pela qual o regime a ser aplicado será o extracontratual, com

398 Ver item 4.3. 
fundamento na responsabilidade pela confiança, em razão da violação ao dever ético e leal de conduta imposto pela ordem jurídica brasileira, consoante já evidenciado.

O mesmo fundamento servirá para responsabilizar aquele terceiro que não possui contrato com qualquer dos negociantes, mas de alguma forma contribuiu para o êxito ou para o fracasso das negociações, como o exemplo citado do arquiteto que aconselhou o dono da obra a adquirir um piso de madeira quando sabidamente não seria o mais adequado para o cômodo a que se destinava.

Todas essas soluções estão pautadas pela conduta antijurídica de um dos negociantes ou de terceiros que causa danos ao outro, violando-se o padrão ético e leal de comportamento insculpido pela nossa ordem jurídica, acarretando, por conseguinte, o dever de reparar os danos decorrentes dessa violação.

No entanto, em algumas delas a reparação dos danos seguirá o regime de responsabilidade decorrente do contrato, em virtude da existência de um vínculo contratual entre as partes, muito embora o fato gerador do dano tenha sua origem em momento anterior à sua celebração.

Em outros casos, entretanto, a responsabilidade será aquiliana, como na hipótese de ruptura indevida das negociações, em que o vínculo contratual não chega a ser concretizado.

Por essa razão, demonstra-se que a responsabilidade civil é única, mas possui dois regimes distintos decorrentes de opção do legislador civil e não uma natureza contratual ou delitual.

Além disso, será apenas a apreciação casuística que tornará possível a verificação do regime a ser adotado, podendo ser aquele decorrente do contrato, desde que existente um vínculo contratual, ou do delito, na ausência de vinculação contratual entre as partes. 
Feita a análise da fase que antecede a relação contratual, cabe proceder ao estudo da responsabilidade pelos conselhos, informações e recomendações prestados na fase contratual propriamente dita.

\subsection{A responsabilidade pela informação, o conselho e a recomendação, na fase contratual}

Também no âmbito das relações contratuais deve imperar o ethos da confiança e o consequente padrão ético de conduta imposto por nosso ordenamento, a fim de garantir um tratamento equânime aos contratantes, evitando-se as condutas deletérias, caracterizadas por práticas lesivas e pela imposição de cláusulas abusivas típicas da antijuridicidade, mas sem se descurar do interesse social que possa decorrer dessa avença.

Por conseguinte, o contrato deixa de ser um instrumento inviolável, fruto da autonomia da vontade e de sua força obrigatória absoluta, para se transformar em um pacto que pode ser alterado em razão da vontade das partes, ou pelo Poder Judiciário. ${ }^{399}$

Passa-se então ao primado dos princípios da função social dos contratos e da boa-fé objetiva, sem que isso signifique o sepultamento da autonomia da vontade e da força obrigatória dos contratos, essenciais para a concretização da liberdade e da segurança jurídica, só que agora relativizados em razão da dignidade humana, do solidarismo social e da busca por uma justiça distributiva. ${ }^{400}$

399 “A força obrigatória do vínculo contratual, na forma concebida pelo individualismo jurídico, resultou ultrapassada em virtude da constatação inequívoca de que o contrato cria simplesmente uma situação jurídica passível de alterações, pelas partes ou por um poder exterior. Significa que o contrato não gera uma conjuntura definitiva, inconteste e incontroversa, como se queria anteriormente, mas cria uma situação perfeitamente passível de alterações, inclusive externas e posteriores à execução da avença" (Maria Luiza Pereira de Alencar Mayer Feitosa, Paradigmas inconclusos: os contratos entre a autonomia privada, a regulação estatal e a globalização dos mercados, Coimbra: Coimbra Ed., 2007, p. 321).

400 “Ante a complexidade das relações contratuais contemporâneas, nenhum princípio poderá mais gozar da pretensão de liquidez e certeza ou assumir posição privilegiada perante os outros pelo fato de ser mais consentâneo com a doutrina sócio-econômica dominante no atual momento histórico" (Maria Luiza Pereira de Alencar Mayer Feitosa, Paradigmas inconclusos: os contratos entre a autonomia privada, a regulação estatal e a globalização dos mercados, cit., p. 323). 
Assim, ganha relevo a teoria da responsabilidade pela confiança também na seara contratual, posto estimular-se a lealdade, a probidade e a ética entre as partes contratantes, bem como em relação a terceiros, em especial no que tange à responsabilidade por conselhos, recomendações e informações.

De fato, no momento que antecede a conclusão do contrato os negociantes trocam informações essenciais para a sua celebração, até que uma das partes se sinta em condições de formular uma proposta, momento em que se inicia a fase de formação do contrato.

É claro que o processo cognitivo que levou o negociante a formular sua proposta pode demandar os mais variados aspectos, partindo-se de singelos raciocínios, como, por exemplo, aquele que decorre da intenção de comprar pão em uma padaria, hipótese em que as informações prestadas pela outra parte não precisam envolver um considerável grau de complexidade, para chegar a relações contratuais bem mais complexas, como a aquisição de uma empresa produtora de papel por uma multinacional que produza embalagens.

Em todos os casos, contudo, a troca de informações representa fase essencial da formação dos contratos, até mesmo por se considerar que a proposta e a posterior aceitação integram esse processo de difusão de informações.

Dessa forma, a formulação de uma proposta efetiva, clara e determinada, se dá através de um processo informativo que intenta lograr a conclusão do contrato, com a conjugação dos interesses das partes. $\mathrm{O}$ mesmo se diga do ato que enseja a aceitação e que acaba por determinar a conclusão do contrato.

As partes, porém, não estão obrigadas a prestar todas as informações possíveis no momento da formação do contrato nem a prestar todos os esclarecimentos que envolvam a celebração do negócio em questão, posto existir um dever de manter-se informado e de buscar os esclarecimentos necessários para a prática dos atos da vida civil. 
O trato social demanda uma necessidade constante de informações que não podem ser simplesmente imputadas a um dos contratantes, sob a alegação genérica de que é detentor do poder econômico e parte mais forte na relação contratual.

Essa assertiva pode parecer uma heresia à primeira vista, ou um contrassenso, especialmente em uma tese em que se defende a existência de fundamentos para uma responsabilidade pela confiança em nosso ordenamento, mas apenas representa nossa intenção de não se sustentar uma ideia generalizante do princípio da boa-fé, em um conceito elástico através do qual tudo poderia ser considerado violação ao dever de lealdade e honradez nas relações privadas.

Sem querer adentrar em discussões de cunho político-filosófico acerca das iniquidades e das mazelas da ordem capitalista, é fato que nosso sistema se encontra pautado por suas regras, o que significa que as relações de troca sujeitam-se às diretrizes do chamado mercado, visando essencialmente ao lucro e impondo riscos diversos para a sua consecução.

Assim, o vendedor de uma loja de eletrodomésticos não tem o dever de informar que a concorrência está praticando preços mais baixos para determinado produto. Da mesma forma, o proprietário de um automóvel posto à venda não está obrigado a informar ao pretenso comprador que existem outros veículos no mercado em melhores condições que o seu.

Já o vendedor de uma grande loja de departamentos não precisa informar seus clientes sobre todas as características de um contrato de compra e venda, tais como os seus elementos, sua natureza jurídica e seus efeitos, apenas para lograr vender um telefone celular ou uma geladeira. E por mais que um tabelião tenha o dever legal de prestar à outorgante e outorgado as informações necessárias à outorga de uma escritura pública de compra e venda de um imóvel, não está obrigado a discorrer sobre o direito de propriedade, seus meios de aquisição ou sua função social. 
Além desses, infinitos são os exemplos de informações que não geram um dever de esclarecer a outra parte, mas, antes, representam o ônus da contraparte de buscar os esclarecimentos necessários para a conclusão do negócio pretendido.

Como bem ressalva Christophe Fabian, a existência e a abrangência do dever de informar são, em regra, concebidas como "uma ponderação abstrata entre interesses que demandam um direito à informação e interesses que demandam uma proteção da informação". 401

Essa ressalva é fundamental para a determinação da responsabilidade por conselhos, informações e recomendação, impondo-se ao operador do direito que efetue a devida ponderação de interesses antes de se afirmar que existe um dever de esclarecimento ou de informação no caso concreto.

Afinal, também deve existir a boa-fé da contraparte no sentido de agir diligentemente no momento de celebrar o negócio jurídico, buscando esclarecer-se acerca das condições e cláusulas do contrato, agindo com lealdade e ética, antes de intentar a sua rescisão por suposta violação ao dever de informar por parte do outro contratante.

Feita essa ressalva, é fato que a informação prestada dolosamente pelo proponente ou pelo aceitante acarretará o dever de reparar os danos eventualmente causados em razão dessa ilicitude.

O mesmo se diga de um conselho apresentado apenas com o intuito de levar a outra parte a aceitar a proposta que lhe foi formulada ou de uma recomendação eivada de dolo e que pretenda beneficiar apenas uma das partes contratantes.

Como exemplo, pense-se em uma informação prestada dolosamente pela contraparte, visando apenas à conclusão do negócio, tal como o cirurgião que informa ao seu paciente sobre o período de recuperação de determinada cirurgia plástica estética,

401 Christophe Fabian, O dever de informar no direito civil, São Paulo: RT, 2002, p. 48. 
dizendo tratar-se de uma fase rápida e indolor, apenas para levá-lo à mesa de operações e lograr auferir os seus honorários, quando sabidamente se está diante de uma recuperação lenta e dolorosa. Poderia o paciente reclamar por perdas e danos decorrentes de uma informação prestada em momento anterior à celebração do contrato?

Ou um advogado que, em uma primeira consulta, aconselha vivamente o cliente a postular em juízo apenas visando à percepção de seus honorários, pois sabe que as chances de êxito são absolutamente reduzidas em virtude de farta jurisprudência contrária aos interesses do consulente, informação maliciosamente ocultada pelo consultor. Caberia, neste caso, um direito a indenização por parte do cliente lesado?

A resposta, para ambos os casos, parece óbvia, no sentido de se garantir a devida reparação dos danos às vítimas das ações perpetradas pelo médico e pelo advogado, posto que ambos possuem um dever legal de prestar aos seus clientes, da maneira mais ampla e cristalina possível, as informações necessárias ao exercício de seu mister.

Da mesma forma, os dois profissionais devem aconselhar aqueles que procuram por seus serviços da forma mais completa e leal, em virtude do dever primário de prestação imposto pela ordem jurídica.

De fato, as necessidades da vida social, das relações de troca e do comércio impõem, por diversas vezes, o dever de informação e o dever de conselho a inúmeros profissionais, o que cria, como consequência, uma responsabilidade pelos conselhos e informações, bem como pelos pareceres cedidos aos seus clientes a título no mais das vezes oneroso.

Como exemplo, pode-se citar a figura do próprio advogado, cujo relacionamento com o cliente está pautado pela transferência de toda uma carga cognitiva, através de informações, conselhos e recomendações, capaz de permitir ao consulente a tomada de uma decisão acerca dos problemas jurídicos que o levaram em busca do amparo deste profissional. 
Não se deve olvidar, todavia, que o parecer do advogado fundamenta-se em informações prestadas por seu cliente, em um processo de troca bastante característico das relações intersubjetivas.

No entanto, as informações prestadas pelo consulente, em regra, consistem somente na transmissão de fatos, na expectativa de que o profissional possa apresentar o seu parecer sobre o caso concreto, ao passo que o advogado aconselha o seu cliente à prática de algum ato ou à tomada de uma posição, ${ }^{402}$ de acordo com o que julgue ser a melhor solução para a situação que lhe foi trazida.

Esse é o caso da responsabilidade pela realização de auditorias fiscais, trabalhistas e empresariais, de que tratamos no item atinente à responsabilidade précontratual, eis que o escritório de advocacia, na denominada due diligence, assume uma obrigação que tem por objeto principal a prestação de informações essenciais à concretização do negócio pretendido pelo cliente, além de exarar um parecer com suas considerações, em que recomenda a tomada de determinadas medidas e aconselha ou não a entabulação do negócio. Trata-se de caso inequívoco de aplicação do regime de responsabilidade contratual previsto pelos arts. 389 e seguintes do Código Civil.

Por sua vez, o advogado pode recomendar um terceiro ao cliente, hipótese em que poderá responder por essa recomendação. Cite-se, por exemplo, a situação em que um causídico recomenda a contratação de um psicólogo para assistir seu cliente em uma lide de família, não por sua comprovada competência, posta à prova por reiterados erros cometidos anteriormente, mas somente em razão do interesse em receber uma gratificação prometida pelo profissional por ele indicado. Imaginemos que o cliente estivesse em dúvida quanto à capacidade profissional desse psicólogo e somente dado andamento às tratativas negociais e decidido pela celebração do contrato após ouvir viva recomendação de seu procurador. Seria possível pleitear uma indenização de seu

\footnotetext{
402 "Conceitualmente, conselho e recomendação distinguem-se da informação por implicarem uma tomada de posição acerca de um ato futuro do destinatário, uma qualquer 'exortação' para este agir em certo sentido, enquanto a informação é neutra, mera transmissão de um fato objetivo (um status $q u o$ ). Na prática, a distinção é com frequiência evanescente, podendo o que formalmente se apresenta como informação ter o alcance do verdadeiro conselho, e aparecendo muitas vezes as diversas espécies ligadas (v.g. informações para fundamentação e conselho)" (Jorge Ferreira Sinde Monteiro, Responsabilidade por conselhos, recomendações ou informações, cit., p. 586).
} 
advogado na hipótese de ter sido prejudicado pela incompetência profissional do psicólogo?

A resposta, em nossa opinião, é positiva, fundada no inculcar da confiança por parte do advogado, somente para que concluísse o contrato com o psicólogo, fato esse que lhe renderia frutos e que acabou por causar danos ao contratante.

Deste modo, verifica-se que o advogado tem o dever geral de agir de maneira ética e proba no exercício de sua profissão, respondendo pelos danos causados em virtude de ações perpetradas com dolo ou culpa, nos termos do art. 32 do Estatuto da Advocacia $^{403}$ (Lei n. 8.906, de 04 de julho de 1994).

Além disso, também deve "aconselhar o cliente a não ingressar em aventura judicial", assim como possui o dever de "informar o cliente, de forma clara e inequívoca, quanto a eventuais riscos da sua pretensão, e das consequências que poderão advir da demanda", nos termos dos arts. $2 .^{\circ}$, inc. VII. e $8 .^{\circ}$ do Código de Ética do Advogado, respectivamente.

Resta claro o fato de existir em nosso ordenamento um dever legal de conduta ética e leal imposto àqueles que pretendem exercer a advocacia, enquanto dever primário de conduta, e que constitui fonte de outros deveres tais como os de esclarecimento e informação, proteção e segurança.

A sua violação gera o dever de reparar os danos que dela decorram, em virtude de imputação normativa expressa nesse sentido, aliada à antijuridicidade da conduta do profissional.

Desse modo, o advogado deve agir de acordo com esse padrão ético de conduta ao prestar informações ao seu cliente, bem como ao recomendar a prática de

403 “Art. 32. O advogado é responsável pelos atos que, no exercício profissional, praticar como dolo ou culpa. Parágrafo único. Em caso de lide temerária, o advogado será solidariamente responsável com seu cliente, desde que coligado com este para lesar a parte contrária, o que será apurado em ação própria." 
um determinado ato ou a aquisição de um bem. Esse dever perdura mesmo na hipótese de aconselhar seu cliente acerca da melhor solução para os problemas que lhe foram apresentados.

Contudo, talvez seja a medicina a área em que esses deveres de informação e de conselho demonstram-se mais latentes, assim como o dever de recomendação, eis que a relação com o paciente funda-se em uma base alicerçada eminentemente pela confiança no diagnóstico apresentado pelo profissional médico. ${ }^{404}$

Nessa relação existe, em regra, uma troca de informações entre médico e paciente, pautada pelo depósito recíproco de confiança entre os interlocutores, pois o primeiro crê que o enfermo lhe transmite todas as informações acerca de seus sintomas, ao passo que o segundo espera do profissional um diagnóstico preciso e, se possível, a solução para os seus problemas de saúde, confiando que as prescrições médicas serão baseadas nos melhores esforços, conhecimento e técnica de seu responsável.

Em outros casos, entretanto, a troca de informações entre paciente e médico não se verifica, como ocorre nos atendimentos de urgência, em que o enfermo encontrase inconsciente desde o primeiro momento em que é atendido. Nessas hipóteses, porém, o médico acaba por contatar familiares do paciente ou até mesmo as pessoas que o tenham levado ao hospital, ocasião em que também se efetiva a difusão de informações, de uma forma talvez não tão eficiente como quando decorre do contato direto médicopaciente.

Em todas essas situações, no entanto, as informações prestadas pelos pacientes ou por seus familiares correspondem, no mais das vezes, ao relato de fatos, sem conteúdo valorativo sobre eles, enquanto os conselhos, informações e recomendações apresentados pelos médicos apresentam um sentido de exortação e a presunção de um conhecimento de causa, cuja importância é majorada por se tratar diretamente do bem da vida e da integridade física do paciente.

\footnotetext{
404 "O médico é, ao mesmo tempo que conselheiro, protetor e guarda do enfermo que lhe reclama os cuidados profissionais" (José de Aguiar Dias, Da responsabilidade civil, Rio de Janeiro: Forense, 1944, v. 1, p.267)).
} 
Porém, o âmbito de atuação do médico é muito vasto e o nível de informações que deve prestar pode variar de acordo com as características da doença, a forma e a duração do tratamento terapêutico que se pretenda adotar, o nível de instrução do próprio paciente, enfim, uma infinidade de fatores que podem influenciar no diagnóstico médico e em um dever de esclarecimento, o que deverá ser analisado no caso concreto, de acordo com os valores, princípios e normas de nosso sistema.

Neste diapasão, diversos são os dispositivos do Código de Ética Médico relacionados às informações, conselhos ou recomendações, tais como o art. 41, ${ }^{405}$ que impõe dever de esclarecer o trabalhador sobre as condições de trabalho que ponham em risco a sua saúde, ou o art. $42,{ }^{406}$ que proíbe a indicação de atos médicos desnecessários ou vedados por nossa legislação.

Ao médico também é defesa a realização de quaisquer procedimentos sem o esclarecimento e a devida autorização do paciente ou de seu responsável, salvo nos casos de perigo de vida iminente, assim como lhe é vedado limitar o poder decisório do paciente acerca de seu bem-estar ou de seu tratamento, conforme preconizam os arts. 46 e 48 do Código de Ética Médico, respectivamente. ${ }^{407}$

Por outro lado, o médico deve sempre informar ao paciente sobre o seu diagnóstico, assim como sobre os prognósticos, a duração e os riscos do tratamento, a menos que entenda que essa comunicação poderá ser gravosa ao enfermo, hipótese em que deverá prestar todas essas informações ao seu responsável. ${ }^{408}$

405 "É vedado: Art. 41. Deixar de esclarecer o paciente sobre as determinantes sociais, ambientais ou profissionais de sua doença."

406 "É vedado: Art. 42. Praticar ou indicar atos médicos desnecessários ou proibidos pela legislação do País."

407 "É vedado ao médico: Art. 46. Efetuar qualquer procedimento médico sem o esclarecimento e consentimento prévios do paciente ou de seu responsável legal, salvo iminente perigo de vida. (...) Art. 48. Exercer sua autoridade de maneira a limitar o direito do paciente de decidir livremente sobre a sua pessoa ou seu bem-estar."

408 De acordo com o art. 59 do Código de Ética Médico, é vedado ao profissional médico "deixar de informar ao paciente o diagnóstico, o prognóstico, os riscos e objetivos do tratamento, salvo quando a comunicação direta ao mesmo possa provocar-lhe dano, devendo, nesse caso, a comunicação ser feita ao seu responsável legal”. 
Como se vê, em todas essas situações ressalta o dever de informação e conselho do profissional médico, decorrente de uma imputação normativa, cuja violação constitui fonte da obrigação de reparar os danos que dela decorram. Ademais, o profissional médico possui o dever de recomendação, como nas hipóteses relacionadas à exortação para determinada conduta (repouso, não ingerir bebidas alcoólicas) ou para realização de certo tratamento terapêutico (fisioterapia, RPG - Reeducação Postural Global).

Por essa razão, partilhamos da opinião de que a obrigação médica, em nosso ordenamento, apresenta como diretrizes o dever de segurança imposto a todos os fornecedores de produtos e serviços pelo nosso Código de Defesa do Consumidor, além de um dever de conduta ético, probo e leal, capitaneado pelo ethos da confiança.

De fato, ao fundamentar a responsabilidade pelos conselhos, recomendações e informações médicos no dever de segurança e na confiança, imputa-se àquele profissional que exerce a medicina os mesmos padrões de conduta que representam a base valorativa de nosso ordenamento.

Deve-se ressalvar, todavia, que a análise de todas as hipóteses em que exsurge o dever de informação do profissional médico constitui, de per si, material para outra tese, razão pela qual não se pretende exaurir as situações em que existe o dever de informar no exercício da medicina.

$\mathrm{Na}$ verdade, o que se pretende é afirmar que em diversas atividades profissionais o dever de informação e de conselho decorre de uma imputação objetiva da norma, o que significa que a sua violação consubstancia fonte da responsabilidade civil, eis que violado um dever primário causando-se dano a outrem.

Essa assertiva é válida não só para o profissional médico, mas também para o advogado, como vimos, ou para o contabilista que, por exemplo, aconselhe seu cliente a entregar sua declaração anual de renda seguindo as suas instruções expressas, que são 
contrárias às instruções normativas da Receita Federal e acabam por resultar em uma vultosa autuação do fisco. ${ }^{409}$

De fato, em virtude da crescente complexidade das relações privadas e da consequente especialização das tarefas cotidianas, é cada vez mais frequente o recurso a especialistas ou peritos para a prática dos atos necessários para a vida em sociedade. ${ }^{410}$

Portanto, ressalta-se mais uma vez o valor da confiança no trato intersubjetivo, em especial nas relações contratuais, impondo-se àqueles que exercem profissões com inequívoco interesse púbico determinados padrões de conduta a fim de conferir mais segurança e proteção aos sujeitos de direito, bem como proceder à tutela do mais vulnerável de forma mais eficiente, em consonância, inclusive, com as diretrizes da legislação consumerista.

Contudo, deve-se frisar que, no caso dos profissionais mencionados, a obrigação de informar, dar conselhos ou recomendar consiste exatamente no objeto do contrato celebrado com seus respectivos clientes, o que significa que uma informação defeituosa, um conselho negligente ou uma recomendação desprovida de fundamento e cuidado constituem hipótese de inadimplemento, que pode ser absoluto ou relativo, fazendo com que o devedor que deixou de cumprir sua obrigação responda pelas perdas e danos causados ao credor.

Destarte, nessas hipóteses o contrato tem como seu objeto uma prestação de informação, conselho ou recomendação, que deve ser adimplida sob pena de o devedor responder pelas perdas e danos a que der causa, mais juros, correção monetária e honorários advocatícios. Assim, o próprio sistema jurídico já possui regras que disciplinam a responsabilidade pelos conselhos, informações e recomendações neste caso.

409 De acordo com o Estatuto do Contabilista, art. 3. ${ }^{\circ}$, inc. XI, não pode o contabilista "prejudicar, culposa ou dolosamente, interesse confiado a sua responsabilidade profissional".

410 “Com a progressiva complexidade das estruturas de mercado, a colaboração de peritos ou especialistas adquire maior importância, não tendo muitas vezes o leigo meios de comprovar criticamente as informações provenientes daqueles, que se tornam em fator decisivo da formação da vontade" (Jorge Ferreira Sinde Monteiro, Responsabilidade por conselhos, recomendações ou informações, cit., p. 606). 
Porém, a obrigação de apresentar um parecer científico em área alheia às ciências exatas constitui uma obrigação de meio e não de resultado, de forma que não se pode pretender uma certeza absoluta de que as recomendações exaradas pelo expert signifiquem a ausência de quaisquer riscos e a garantia de sucesso na empreitada a que se propõem.

Seja para o ajuizamento de uma ação, para a realização de uma cirurgia de redução do estômago ou a dedução de uma despesa na declaração de renda, o aconselhamento e a recomendação formulados pelo profissional não são garantia de uma sentença favorável, da perda de peso almejada ou da ausência de fiscalização por parte da Receita Federal.

Estes fatos devem ser devidamente apurados antes de se chegar à fácil conclusão acerca de uma violação das expectativas da vítima, em uma concepção generalizante da confiança e da boa-fé, que acabe por desconsiderar todo o sistema jurídico e as próprias vicissitudes da vida em sociedade, pois o desenvolvimento das relações intersubjetivas envolve necessariamente a assunção de riscos, e a celebração de um contrato não constitui exceção a essa realidade.

Ora, o sujeito que resolve realizar uma cirurgia de redução do estômago sabe que não terá a certeza de que perderá o número exato de quilos pretendidos. É certo que o médico deve prestar os devidos esclarecimentos acerca dos riscos que envolvem a intervenção cirúrgica em tela e obter o consentimento informado de seu paciente, sob pena de estar descumprindo com o seu dever legal e contratual. Entretanto, o cirurgião não responderá pelo resultado da operação, apesar de ter informado devidamente o seu paciente (informação), recomendando profissionalmente a intervenção cirúrgica (recomendação), dizendo que se estivesse na mesma situação faria a cirurgia (conselho).

Dessa forma, verifica-se que a imputação da responsabilidade, nesses casos, não pode prescindir da prova da culpa ou do dolo do profissional, caracterizando-se 
hipótese de responsabilidade subjetiva, o que, ressalte-se, está expresso pelo art. 14, 4. ${ }^{\text {o }}{ }^{411}$ do Código de Defesa do Consumidor.

Reitera-se, assim, a necessidade de se recorrer ao sistema para a solução de casos concretos, a fim de não se basear em discursos generalizantes que acabam por reduzir nosso ordenamento aos princípios da dignidade humana, da função social e da boa-fé objetiva.

Deste modo, vimos que a informação, o conselho e a recomendação podem consistir no próprio objeto do contrato, analisando as suas consequências. Em outros casos, entretanto, não constituem a prestação objeto da relação contratual, mas, na qualidade de deveres anexos, também chamados laterais ou secundários, podem gerar a obrigação de reparar danos, desde que caracterizada a sua violação. ${ }^{412}$

O tema já foi discutido no capítulo segundo de nossa tese e leva às hipóteses de violação positiva do contrato, na denominação cunhada por Hermann Staub em 1902 e que na definição de Jorge Cesa Ferreira da Silva pode ser entendida como "todo inadimplemento decorrente do descumprimento culposo do dever lateral, quando este dever não tenha uma vinculação direta com os interesses do credor na prestação". 413

Christophe Fabian faz acurada análise acerca dos deveres anexos relacionados à informação, distinguindo-os em três grupos. No primeiro encontram-se os deveres anexos de prestação, que consistem no dever de uma parte respeitar os interesses da outra, ajudando a contraparte na realização da prestação e evitando tudo o que poderia dificultar ou impedir a realização do contrato. Em um segundo grupo concentram-se os deveres anexos de proteção, que existem independentemente da

411 “Art. 14. O fornecedor de serviços responde, independentemente da existência de culpa, pela reparação dos danos causados aos consumidores por defeitos relativos à prestação dos serviços, bem como por informações insuficientes ou inadequadas sobre sua fruição e riscos. (...) $\S 4 .^{\circ}-\mathrm{A}$ responsabilidade pessoal dos profissionais liberais será apurada mediante a verificação de culpa".

412 Sobre o tema, Christophe Fabian ressalva a existência de um escalonamento relacionado à intensidade do dever de informar "que começa com o direito subjetivo como meio mais forte e efetivo de se conseguir a informação e continua como o dever de informar para fundamentar um direito secundário, principalmente um dever à indenização" ( $O$ dever de informar no direito civil, cit., p. 51).

413 Jorge Cesa Ferreira da Silva, A boa-fé e a violação positiva do contrato, cit., p. 272-273. 
vontade das partes, consistindo em proteção aos contratantes ou a seus bens contra prejuízos que podem ser evitados durante o processo da prestação. No terceiro grupo situam-se os deveres anexos de confiança, que impõem um dever de lealdade em todo o contato social, fundamental para o bom funcionamento do sistema jurídico. ${ }^{414}$

Assim, verifica-se que o descumprimento dos deveres anexos ou laterais caracteriza o inadimplemento contratual, podendo ensejar a resolução do contrato e a imputação ao pagamento das perdas e danos por parte do responsável pela sua violação.

Cite-se, por exemplo, o caso de um vendedor que recomenda a compra de determinado televisor sem informar ao cliente que várias de suas inúmeras funções são incompatíveis com o aparelho de DVD que também pretende adquirir, o que caracteriza afronta ao dever anexo de informação, muito embora tenha gentilmente prestado todas as informações solicitadas pelo comprador, que se olvidou de perquirir acerca da compatibilidade entre os dois aparelhos.

Na hipótese da violação positiva do contrato resta evidenciada a importância da boa-fé objetiva em sua função supletiva, consoante anteriormente demonstrado, terreno propício para a concretização da responsabilidade pela confiança sob o regime contratual.

A dificuldade, nestes casos, será provar a existência do nexo de causalidade entre a conduta do agente e o dano, pois em muitos casos é árduo e intrincado o trabalho de perquirir se a recomendação ou o conselho foram essenciais para a conclusão do negócio ou não.

No entanto, com a demonstração do nexo de causalidade entre a conduta antijurídica e os prejuízos causados à vítima, surgirá, nestes casos, o dever de reparálos, comprovada a violação aos deveres anexos de conduta. Isso porque existe um critério objetivo estabelecido pela norma que corresponde, exatamente, à violação dos citados deveres anexos, cuja apuração ficará a cargo do julgador.

414 Christophe Fabian, O dever de informar no direito civil, cit., p. 64-67. 
Outro ponto que merece ser analisado diz respeito ao dever de sigilo, cuja violação pode gerar o dever de reparar o dano por ela causado. Não se pretende tratar das confidências feitas a amigos ou parentes, cuja divulgação em regra não gera a obrigação de reparar os danos causados, senão uma reprovação pública ou a chamada "dor na consciência", mas tratar das relações contratuais que impõem um dever de não se revelar determinadas informações ou até mesmo o dever profissional de sigilo, como ocorre com o psicólogo, o médico ou o advogado.

Nesses casos, mais uma vez ressalta-se o valor da confiança como fundamental para a vida em sociedade e para as relações intersubjetivas, eis que o segredo representa o depósito da fidúcia em seu destinatário e de uma expectativa de que essa informação não será revelada, especialmente tratando-se de confidências a profissional, como um psicólogo. ${ }^{415}$

O dever de segredo pode resultar de uma imposição decorrente do exercício de determinada profissão, como a do psicólogo, em que existe o dever de respeitar o sigilo profissional, respeitando-se a intimidade e a vida privada de seus pacientes, nos termos do art. 9. ${ }^{\text {416 }}$ do Código de Ética Profissional do Psicólogo.

Esse mesmo dever de sigilo é imposto a diversos outros profissionais, como nos exemplos do advogado ${ }^{417}$ ou do contabilista, ${ }^{418}$ citados anteriormente ao se discutir a

415 “A confiança que se impõe no exercício de algumas profissões fez com que a lei sancione a transgressão do dever profissional, fundada em razões morais, que vão muito além do dano que se poderia causar, já que é nessa confiança que repousa a tranquilidade de quem seja induzido a confiar seus segredos por necessidade." No original: "La confianza que se impone en el ejercicio de algunas profesiones, ha hecho que la ley sancione la transgresión del deber profesional, fundada en razones morales, que van mucho más allá del daño que se podría causar, ya que, es en esa confianza donde reposa la tranquilidad de quien se ha visto inducido a confiar sus secretos por la necesidad" (Marcos Edgardo Azerrad; Guillermo Alberto Folrio; Marta Suzana Azerrad, El secreto profesional y el deber de confidencialidad, Mendoza: Ediciones Juridicas Cuyo, 2003, p. 18).

416 “Art. 9. ${ }^{\circ}$ É dever do psicólogo respeitar o sigilo profissional a fim de proteger, por meio da confidencialidade, a intimidade das pessoas, grupos ou organizações, a que tenha acesso no exercício profissional."

417 “Do Sigilo Profissional - Art. 25. O sigilo profissional é inerente à profissão, impondo-se o seu respeito, salvo grave ameaça ao direito à vida, à honra, ou quando o advogado se veja afrontado pelo próprio cliente e, em defesa própria, tenha que revelar segredo, porém sempre restrito ao interesse da causa. Art. 26. O advogado deve guardar sigilo, mesmo em depoimento judicial, sobre o que saiba em razão de seu ofício, cabendo-lhe recusar-se a depor como testemunha em processo no qual funcionou ou deva funcionar, ou sobre fato relacionado com pessoa de quem seja ou tenha sido advogado, mesmo que autorizado ou solicitado pelo constituinte. Art. 27. As confidências feitas ao 
responsabilidade pelos seus conselhos, informações ou recomendações. Também na medicina o dever de sigilo é fundamental para a relação entre paciente e médico, como corolário da tutela da intimidade do enfermo, de sua dignidade e a fim de evitar a ocorrência de práticas discriminatórias e preconceituosas em razão da enfermidade diagnosticada. $^{419}$

Destarte, existe imputação normativa no sentido de garantir o segredo de diversos profissionais quando do exercício de suas atividades e também, depois de encerrada a relação contratual, a significar que a violação do dever de sigilo acarretará a obrigação de reparar os danos que dela decorram.

Além disso, é notória a importância do sigilo na seara empresarial, em uma área marcada por intensa concorrência, como se vê, por exemplo, quando do lançamento de um novo veículo por parte de uma das gigantes da indústria

advogado pelo cliente podem ser utilizadas nos limites da necessidade da defesa, desde que autorizado aquele pelo constituinte. Parágrafo único. Presumem-se confidenciais as comunicações epistolares entre advogado e cliente, as quais não podem ser reveladas a terceiros" (Código de Ética do Advogado).

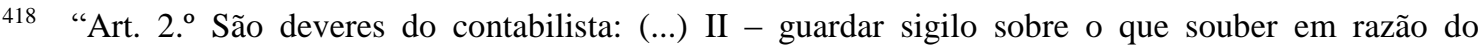
exercício profissional lícito, inclusive no âmbito do serviço público, ressalvados os casos previstos em lei ou quando solicitado por autoridades competentes, entre estas os Conselhos Regionais de Contabilidade" (Código de Ética do Contabilista).

419 "Segredo Médico - É vedado ao médico: Art. 102. Revelar fato de que tenha conhecimento em virtude do exercício de sua profissão, salvo por justa causa, dever legal ou autorização expressa do paciente. Parágrafo único: Permanece essa proibição: a) Mesmo que o fato seja de conhecimento público ou que o paciente tenha falecido. b) Quando do depoimento como testemunha. Nesta hipótese, o médico comparecerá perante a autoridade e declarará seu impedimento. Art. 103. Revelar segredo profissional referente a paciente menor de idade, inclusive a seus pais ou responsáveis legais, desde que o menor tenha capacidade de avaliar seu problema e de conduzir-se por seus próprios meios para solucioná-lo, salvo quando a não revelação possa acarretar danos ao paciente. Art. 104. Fazer referência a casos clínicos identificáveis, exibir pacientes ou seus retratos em anúncios profissionais ou na divulgação de assuntos médicos em programas de rádio, televisão ou cinema, e em artigos, entrevistas ou reportagens em jornais, revistas ou outras publicações leigas. Art. 105. Revelar informações confidenciais obtidas quando do exame médico de trabalhadores, inclusive por exigência dos dirigentes de empresas ou instituições, salvo se o silêncio puser em risco a saúde dos empregados ou da comunidade. Art. 106. Prestar a empresas seguradoras qualquer informação sobre as circunstâncias da morte de paciente seu, além daquelas contidas no próprio atestado de óbito, salvo por expressa autorização do responsável legal ou sucessor. Art. 107. Deixar de orientar seus auxiliares e de zelar para que respeitem o segredo profissional a que estão obrigados por lei. Art. 108. Facilitar manuseio e conhecimento dos prontuários, papeletas e demais folhas de observações médicas sujeitas ao segredo profissional, por pessoas não obrigadas ao mesmo compromisso. Art. 109 - Deixar de guardar o segredo profissional na cobrança de honorários por meio judicial ou extrajudicial" (Código de Ética Médico). 
automobilística ou por toda a aura de segredo e de mistério em torno da verdadeira fórmula da Coca-Cola.

Nestes casos os contratos de trabalho contêm cláusulas de sigilo que impõem vultosas multas para o caso de violação, hipótese em que o dever de segredo não decorre da relação contratual e não, necessariamente, de uma imputação da norma legal. Trata-se de exemplo de obrigação de não fazer, em que o devedor é considerado inadimplente desde o dia em que executou o ato de que se devia abster, nos termos do art. 390 do Código Civil.

Nessas hipóteses, uma das prestações objeto do contrato constitui o dever de sigilo imposto aos contratantes, cujo inadimplemento constituirá o devedor em mora, sujeitando-o ao pagamento de indenização pelas perdas e danos a que der causa, geralmente prefixada na forma de uma cláusula penal, acrescido dos juros, correção monetária e honorários advocatícios.

Em acórdão recente, o Tribunal de Justiça do Estado de São Paulo concedeu liminar para que uma empresa deixasse de divulgar informações técnicas protegidas por uma cláusula de sigilo aposta em um contrato de parceria, sob a fundamentação de que essa prática contraria frontalmente o princípio da boa-fé. ${ }^{420}$

Por outro lado, a violação desse dever de sigilo pode, em alguns casos, gerar alguma espécie de proveito para a parte lesada, situação que deve ser devidamente considerada pelo juiz, podendo determinar a compensação do dano com o lucro eventualmente auferido pela vítima a fim de evitar o seu indevido enriquecimento.

É o caso da chamada compensatio lucri cum damno, que se fundamenta na ideia de não se permitir o indevido enriquecimento do lesado. Na lição de Paulo Mota

\footnotetext{
420 “Agravo de instrumento. Ação inibitória cumulada com indenizatória. Insurgência contra decisão que negou pleito à concessão da tutela antecipada. Contrato de parceria que contém cláusula de sigilo das informações. Rompimento da boa-fé. Liminar parcialmente concedida para que a Agravada deixe de usar o nome da Agravante e associá-lo aos seus produtos ou atividades, interrompendo imediatamente a produção, venda, comercialização e distribuição de cópias de máquinas. Recurso parcialmente provido" (TJSP, AI 615.428.4/7, Ac. 3933557, São Paulo, 7. Câm. de Dir. Privado, rel. Des. Luiz Antonio Costa, j. 15.07.2009, DJESP 27.07.2009).
} 
Pinto, a indenização decorrente do evento lesivo apenas visa a reintegrar os bens do lesado, não podendo se constituir em fonte de lucro ou aumento do patrimônio da vítima. $^{421}$

Como exemplo, podemos citar o caso da modelo que, no contrato celebrado com seu empresário, exigiu a inclusão de uma cláusula de sigilo acerca de seus rendimentos e de sua vida particular. Contudo, referido empresário viola a cláusula de sigilo ao comentar em entrevista para uma grande rede de televisão que sua cliente vivia um tórrido caso com um astro televisivo. A despeito da violação do contrato por parte do empresário, com a divulgação de informações protegidas por uma cláusula de segredo, o fato é que após a divulgação da notícia a procura pelos serviços da modelo aumentou brutalmente, o que resultou na valorização de sua imagem e no consequente incremento em sua renda. Nessa hipótese, o lucro havido em razão da indevida divulgação da informação deve ser compensado com os danos decorrentes da violação do contrato.

Trata-se da figura da compensação do direito das obrigações, trazida a lume para evitar o indevido enriquecimento da vítima, que, a despeito da ocorrência do dano, acaba por beneficiar-se dos efeitos do ato lesivo.

É possível verificar, pois, que a relação contratual impõe deveres mais intensos do que aqueles decorrentes das fases pré e pós-contratual, pois o descumprimento das prestações assumidas no contrato significa afronta a uma operação econômica reconhecida e tutelada pelo direito, cujos efeitos representam "a expressão e a formalização jurídica daquelas transferências de riqueza que constituem a substância de qualquer operação contratual". ${ }^{422}$

Essas operações econômicas estão sempre a correr o risco de serem frustradas por causas das mais diversas, seja, por exemplo, pela inexecução do contrato

\footnotetext{
421 Paulo da Mota Pinto, Interesse contratual negativo e interesse contratual positivo, Coimbra: Coimbra Ed., 2008, v. 1, p. 710.

422 Enzo Roppo, $O$ contrato, cit., p. 211.
} 
por parte de um dos contratantes ou em razão de acontecimentos supervenientes à conclusão do pacto, tornando impossível sua execução.

Nesses casos, o equilíbrio formal existente no momento da celebração do negócio é quebrado e alguma das partes terá de assumir os riscos decorrentes dessa alteração das circunstâncias. Caberá ao julgador determinar quem arcará com os riscos decorrentes da inexecução da obrigação, cuja decisão deverá seguir os parâmetros impostos pela ordem jurídica, através de seus valores, princípios, regras e padrões, que servirão de base para o exercício do poder decisório do juiz.

Dentro destes parâmetros previstos em nosso ordenamento encontram-se os fundamentos para uma responsabilidade pela confiança, no âmbito das relações contratuais, pois, como bem ressalva Rubén S. Stíglitz, a obrigação de informar constitui hoje uma das manifestações do espírito de solidariedade que deve caracterizar esses tempos, especialmente no domínio dos contratos aonde devem acentuar-se os escrúpulos. $^{423}$.

\subsection{A responsabilidade pela informação, o conselho e a recomendação, na fase pós-contratual}

A mesma base de raciocínio que serviu para se chegar à conclusão da existência de uma responsabilidade em momento anterior à celebração do contrato foi utilizada para solucionar questões surgidas posteriormente à extinção da relação contratual, em que ainda subsistem alguns deveres para os contratantes, mesmo que cumprida a prestação objeto da avença.

Neste sentido, Menezes Cordeiro observa que a denominada culpa post pactum finitum corresponde "à projeção simétrica da culpa in contrahendo no período pós-contratual" e sua formação, enquanto instituto jurídico, derivou da necessidade de

\footnotetext{
423 No original: "La obligación de informar constituí hoy una de las manifestaciones del espíritu de solidaridad que debe caracterizar estos tiempos, muy especialmente en los dominios del contracto donde deben acentuarse los escrúpulos" (Rubén S. Stiglitz, La obligación precontractual y contractual de información. El deber de consejo, Revista de Direito do Consumidor, n. 22, p.15, São Paulo: RT, abr.-jun. 1997).
} 
solucionar questões periféricas despontadas após a extinção de um processo contratual, o que a levou a ser reconhecida pela jurisprudência na década de vinte, depois de algumas rejeições iniciais. ${ }^{424}$

Rogério Ferraz Donnini assinala que o marco do acolhimento da responsabilidade pós-contratual na jurisprudência alemã ocorreu em 1925, quando o Reichsgericht (RG) decidiu que o cedente de crédito deveria continuar a não impor obstáculos ao cessionário, ainda que a cessão já tenha sido extinta.

Contudo, não obstante o acolhimento pelos tribunais, a teoria da culpa post pactum finitum não teve a mesma repercussão da culpa in contrahendo, de Jhering, ou das teorias da base do negócio jurídico, de Paul Oertmann, e da violação positiva do contrato, de 1902, de Hermann Staub, seja na Alemanha ou em outros países europeus, posto não haver um número frequente de casos análogos àqueles que permitiram o acolhimento da teoria da responsabilidade pós-contratual, além de não existir uma fundamentação muito precisa acerca do tema no corpo de decisões que recepcionaram a matéria. ${ }^{425}$

Assim, ressalva Rogério Ferraz Donnini que, enquanto a responsabilidade pré-contratual recebe tratamento expresso em legislações distintas, a responsabilidade pós-contratual ou, de forma mais ampla, a pós-eficácia das obrigações, vem sendo enfrentada, principalmente, por doutrina e jurisprudência alemãs, criadoras da culpa post pactum finitum e seguidas pela doutrina portuguesa. ${ }^{426}$

Deste modo, é possível verificar que o desenvolvimento jurisprudencial alemão revelou que, ainda que extinta uma obrigação, podem persistir determinados deveres de conduta, tais como o dever de lealdade, o dever de proteção e o dever de informação.

\footnotetext{
424 António Manuel da Rocha e Menezes Cordeiro, Da boa-fé objetiva no direito civil, cit., p. 625-626.

425 Rogério Ferraz Donnini, Responsabilidade civil pós-contratual, cit., p. 89.

426 Idem, ibidem, p. 89.
} 
Isso porque, mesmo após o cumprimento da obrigação contratual, os sujeitos dessa relação continuavam vinculados ao dever de manter uma conduta leal entre si, a fim de não permitir a frustração dos objetivos que deram causa à celebração do contrato, evitando-se condutas deletérias e chicaneiras capazes de causar prejuízos à contraparte ou diminuir as vantagens auferidas pelo pacto.

Afinal, como bem ressalva Charles Fried, a boa-fé consiste em uma maneira de lidar a parte contratual: honesta e decentemente. É uma noção sugerindo que se evitem as práticas chicaneiras e desonestas (má-fé), seja para se chegar a um acordo ou na realização de seus termos. ${ }^{427}$

Além disso, como corolário do dever de proteção, um contratante deve se abster de provocar danos ao patrimônio ou à pessoa do outro, o que, na verdade, remonta ao neminem laedere.

Por outro lado, e particularmente voltado ao tema da presente tese, ainda vincula as partes o dever de informação, que pode se verificar, por exemplo, no dever de prestar esclarecimentos sobre o funcionamento de um equipamento ou no dever de manter sigilo acerca de informações confidenciais transmitidas no curso do processo contratual.

Destarte, o alicerce em que se baseiam esses deveres e a própria culpa post pactum finitum é o princípio da boa-fé e todos os deveres anexos que correspondem à sua função supletiva, constituindo o fundamento para a responsabilidade pós-contratual.

Nestas situações de eficácia pós-contratual, ressalta, mais uma vez, o valor da confiança, concretizada pela proteção das expectativas criadas pela celebração e pelo cumprimento do contrato, bem como pelo dever ético de conduta imposto aos

427 No original: "Good faith is a way of dealing with contractual party: honestly, decently. It is an adverbial notion suggesting the avoidance of chicanery and sharp practice (bad faith) whether in coming to an agreement or in carrying out its terms" (Charle Fried, Contract as promise. A theory of contractual obligation, Cambridge (Massachusetts): Harvard University Press, 1981, p. 74). 
contratantes em qualquer momento do processo contratual e, até mesmo, após sua extinção. ${ }^{428}$

Assim, não obstante o contrato tenha sido extinto, impõe-se um comportamento probo, leal e ético aos contratantes, não obstante o contrato tenha sido extinto, pois os efeitos da obrigação protraem-se para um momento posterior à sua extinção, consubstanciados por esses deveres de conduta que, aliás, são impostos a todos em razão da ordem valorativa de nosso sistema jurídico.

Esses casos de eficácia pós-contratual encontram fundamento na responsabilidade pela confiança e sua concreção pela boa-fé objetiva e em seus deveres anexos de proteção, informação e esclarecimento e de lealdade.

Destarte, a confiança e a boa-fé objetiva constituem a base necessária para aferir as consequências causadas por informações, conselhos e recomendações em momento posterior à extinção do contrato, bem como verificar a necessidade de reparar os danos que delas decorram, seja pelo regime contratual de responsabilidade, seja pelo regime extracontratual.

Em alguns casos a responsabilidade por informações, conselhos e recomendações está claramente vinculada ao contrato, como, por exemplo, nas hipóteses em que existe uma cláusula de sigilo impondo-se um dever de confidencialidade às partes contratantes mesmo após a extinção do contrato.

Essas cláusulas são comuns em contratos de trabalho, obrigando os empregados à manutenção de sigilo acerca de informações essenciais ao

\footnotetext{
428 Na busca dos vetores materiais que concretizam a boa-fé nas ocorrências pós-eficácia, deparam-se, no essencial, a confiança e a materialidade das situações em jogo. A confiança requer a proteção no período subsequente ao da extinção do contrato, das expectativas provocadas na sua celebração e no seu cumprimento, pelo comportamento dos intervenientes. A materialidade das situações exige que a celebração e o acatamento dos negócios não se tornem meras operações formais, a desenvolver numa perspectiva de correspondência literal com o acordado, mas que, na primeira oportunidade, se esvaziam de conteúdo. "O escopo contratual não pode ser frustrado a pretexto de que a obrigação se extinguiu" (António Manuel da Rocha e Menezes Cordeiro, Da boa-fé objetiva no direito civil, cit., p. 630).
} 
desenvolvimento das atividades do empregador, ainda que o vínculo empregatício entre as partes seja extinto.

Outro exemplo de eficácia pós-contratual consiste na cláusula de preempção ou preferência, em que, após a conclusão e execução do contrato de compra e venda, o comprador fica obrigado a oferecer ao vendedor a coisa objeto do contrato de venda e compra, dentro de um determinado prazo. ${ }^{429}$

Essa obrigação ainda persiste na hipótese de receber uma proposta de terceiros, quando deverá informar ao alienante acerca de seus termos para que esse possa exercer o direito de preferência se assim o quiser. ${ }^{430}$

Nestes casos, entendemos que o regime de responsabilidade pela quebra do dever de sigilo é contratual, em virtude da clara e inequívoca violação de uma das condições do contrato que permanece produzindo eficácia.

Em outros casos, contudo, a eficácia pós-contratual não está expressamente prevista no contrato, mas decorre da concretização dos deveres anexos à boa-fé objetiva e do valor fundamental da confiança.

Como exemplo, cite-se a hipótese em que, após vender um veículo a um colega de trabalho, o vendedor recomende aos demais colegas que jamais comprem aquele automóvel ou o caso de um transportador que, depois de transportar os equipamentos de seu cliente e entregá-los em uma feira comercial em outro município, começa a desaconselhar os interessados na aquisição do bem, informando detalhes das condições do transporte por ele mesmo realizado.

429 “Art. 513. A preempção, ou preferência, impõe ao comprador a obrigação de oferecer ao vendedor a coisa que aquele vai vender, ou dar em pagamento, para que este use de seu direito de prelação na compra, tanto por tanto. Parágrafo único. O prazo para exercer o direito de preferência não poderá exceder a cento e oitenta dias, se a coisa for móvel, ou a dois anos, se imóvel."

430 “Art. 514. O vendedor pode também exercer o seu direito de prelação, intimando o comprador, quando lhe constar que este vai vender a coisa." 
Nessas hipóteses avulta a violação ao dever de lealdade e a quebra da confiança depositada no momento da celebração do contrato e que deve persistir depois de sua extinção, de acordo com os ditames da boa-fé, ressaltando-se exatamente os fundamentos da responsabilidade pela confiança.

Ademais, existem terceiros que podem ser prejudicados pelos efeitos produzidos após a celebração do contrato, o que serve para reiterar o cabimento da responsabilidade pós-contratual.

Neste sentido, pode-se citar a lição de Rogério Ferraz Donnini, ao observar que o ato de extinção da procuração pelo mandante, através da revogação, não produz efeitos perante os terceiros de boa-fé que trataram com o mandatário, se apenas este último foi notificado, nos termos do art. $686^{431}$ do Código Civil. ${ }^{432}$

Por conseguinte, o mandante responderá até mesmo pelas informações, conselhos ou recomendações prestados pelo mandatário ao terceiro de boa-fé posteriormente à revogação do mandato.

Conclui-se, pois, que a a quebra do dever ético de conduta também constitui fundamento da responsabilidade pós-contratual, cabendo ao julgador sopesar os interesses das partes, levando-se em consideração o fato de que o fim do contrato libera as partes de suas obrigações, mas não as exime de manter um comportamento pautado pela ética e pela lealdade.

\subsection{A responsabilidade pela informação, o conselho e a recomendação, nas relações intersubjetivas dissociadas do contrato}

Existem diversas relações entre particulares que não apresentam nenhum vínculo contratual nem se realizam em momento anterior ou posterior à celebração de

\footnotetext{
431 “Art. 686. A revogação do mandato, notificada somente ao mandatário, não se pode opor aos terceiros que, ignorando-a, de boa-fé com ele trataram; mas ficam salvas ao constituinte as ações que no caso lhe possam caber contra o procurador."

432 Rogério Ferraz Donnini, Responsabilidade civil pós-contratual, cit., p. 127.
} 
um contrato, mas em que a troca de informações, o aconselhamento ou as recomendações podem constituir fonte de danos, impondo-se a sua reparação.

Imagine-se, por exemplo, uma situação em que o funcionário de um escritório foi preterido na escolha de uma vaga de supervisor por um colega casado e para se vingar envia vários e-mails à esposa deste último informando falsamente que seu marido mantinha um caso com a chefe. Essa informação acabou por resultar no fim do matrimônio do colega de trabalho. Haveria um dever de reparar os danos causados por essa reprovável atitude?

Em outro exemplo, suponhamos que um empregador demita seu funcionário por haver cometido um pequeno furto, mas mesmo assim o recomende a outrem, sem ressalvar o ocorrido, pensando tratar-se de um caso isolado, e sem atinar para o fato de que o destinatário da recomendação pretende suprir uma vaga de vigia noturno em sua joalheria, que acaba sendo furtada, dias depois, pelo empregado em questão. Poderia o dono da joalheria exigir uma indenização por desídia no ato de recomendar ou pela omissão, ainda que involuntária, da recomendação?

Nesses casos não existe uma relação contratual entre os colegas de trabalho nem entre o dono da joalheria e o responsável pela recomendação do criminoso funcionário. Não obstante, o dever de reparar os danos decorrentes da informação falsa e da recomendação negligente nos parece ser cristalino.

Nessas situações, a conduta dolosa daquele que enviou os e-mails e a conduta culposa do responsável pela recomendação são bastante evidentes e tipificam o ato ilícito previsto pelo art. $186^{433}$ do Código Civil, hipótese clara de responsabilidade civil aquiliana.

Em outros casos, contudo, a antijuridicidade não é tão aparente e fica muito difícil comprovar o nexo de causalidade entre o conselho, a recomendação ou a informação prestada numa relação intersubjetiva.

433 “Art. 186. Aquele que, por ação ou omissão voluntária, negligência ou imprudência, violar direito e causar dano a outrem, ainda que exclusivamente moral, comete ato ilícito." 
Como bem ressalva Nelson Nery Junior, em se tratando de responsabilidade civil, é possível se incorrer com facilidade em equívocos, caso não sejam consideradas premissas teóricas importantes, tais como aquela que fundamento essencial do ato ilícito e consiste na presença do nexo causal entre a ação do causador do suposto dano e a vítima do resultado danoso. Além deles, deve-se considerar a distinção entre dano e resultado meramente prejudicial, a fim de se apurar a presença do dano jurídico em determinados eventos concretos. ${ }^{434}$

Por outro lado, existem outros prejuízos que não podem ser imputados a nenhum sujeito, devendo ser suportados por aquele que os sofreu, evidenciando-se a possibilidade de prejuízo sem dano ${ }^{435}$, o que ocorre, inclusive, quando da divulgação de informações ou em decorrência de conselhos e recomendações tão comuns ao trato social.

De fato, não se deve olvidar que um número infinito de informações é transmitido na vida cotidiana, assim como os conselhos e as recomendações são característicos do convívio social e essenciais para o desenvolvimento das relações humanas.

No entanto, a transmissão da informação não é culturalmente neutra e carrega consigo um conteúdo valorativo formado pelo seu emissor e que será ou não capaz de influenciar o destinatário.

Muito da experiência que se transmite de geração a geração decorre dos conselhos e recomendações passados de pai para filhos ou dos mais velhos aos mais novos. É assim também que os costumes se perpetuam na sociedade, e até mesmo a

434 Nelson Nery Junior, Ações de indenização fundadas no uso do tabaco. Responsabilidade civil pelo fato do produto: julgamento antecipado da lide. Ônus da Prova e cerceamento de defesa. Responsabilidade civil e seus critérios de imputação. Autonomia privada e dever de informar. Autonomia privada e risco social. Situações de agravamento de risco, in: Teresa Ancona Lopez (Coord.), Estudos e pareceres sobre livre-arbitrio, responsabilidade e produto de risco inerente. $\mathrm{O}$ paradigma do tabaco: aspectos civis e processuais, Rio de Janeiro: Renovar, 2009, p. 390-391.

435 Nelson Nery Junior, Ações de indenização fundadas no uso do tabaco. Responsabilidade civil pelo fato do produto: julgamento antecipado da lide. Ônus da Prova e cerceamento de defesa. Responsabilidade civil e seus critérios de imputação. Autonomia privada e dever de informar. Autonomia privada e risco social. Situações de agravamento de risco, cit., p. 391. 
forma com que muitos valores solidificam-se na sociedade decorre das máximas da experiência, transmitidas ao longo da história. ${ }^{436}$

Ora, o conselho e a recomendação são inerentes ao contato social, assim como ocorre com a transmissão das informações, razão pela qual o julgador deve ser muito criterioso na apuração da responsabilidade decorrente desses conselhos, recomendações e informações nas relações intersubjetivas.

Por conseguinte, deve-se evitar a ampliação desmesurada do âmbito da responsabilidade civil, na tentativa de acabar com os riscos inerentes às relações sociais, escolhendo-se arbitrariamente alguns responsáveis pelos danos ou prejuízos que são imanentes à convivência humana. ${ }^{437}$

Todavia, existem situações em que o responsável pelo conselho, pela informação ou pela recomendação possui verdadeira ascendência sobre o destinatário, seja por uma aparente competência profissional, seja por uma posição hierarquicamente superior.

Nessas hipóteses, é possível que exista um dever de reparar os danos causados pelos conselhos, informações ou recomendações, desde que muito bem demonstradas a conduta antijurídica de seu emissor, a culpa, o dano e o nexo de causalidade.

De fato, a recomendação prestada por um renomado economista para que seu jardineiro aplique todas as suas economias em um arriscadíssimo fundo de ações, que depois vem a sofrer a intervenção do Banco Central em virtude das irregularidades

\footnotetext{
436 Neste sentido, observa Miguel Reale que "a mais relevante das conseqüências do a priori cultural é, por assim dizer, a axiologização universal da experiência" (Cinco temas do culturalismo, São Paulo: Saraiva, 2000, p. 50).

437 "Conselho e informação estão em tão estreita ligação com os contatos do dia-a-dia que uma responsabilidade alargada por declarações negligentes levaria longe demais; até porque a 'palavra' facilmente atinge um grande número de pessoas (basta pensar em informações econômicas publicadas em jornais), podendo conduzir a um dever de indenização face a um número indeterminado de pessoas, por montantes incalculáveis. A própria liberdade de expressão ou de manifestação seria posta em causa" (Jorge Ferreira Sinde Monteiro, Responsabilidade por conselhos, recomendações ou informações, cit., p. 587).
} 
praticadas pelo mercado e tornadas públicas há meses pela imprensa, pode gerar o dever de reparar os danos causados pela perda total dos recursos do trabalhador.

Como parâmetros há que se perquirir pela existência de uma conduta culposa ou dolosa por parte daquele que aconselhou, informou ou recomendou, ponderando-se com a liberdade de ação e de expressão, bem como com a tutela da confiança e da boa-fé.

Há ainda que se ressaltar o nexo de causalidade entre a conduta do agente que divulgou a informação, deu o conselho ou recomendou e o dano causado pela vítima, consistente na relação intrínseca entre acontecimento e resultado. ${ }^{438}$

Como se vê, a atuação do magistrado será indispensável para se promover o devido sopesamento entre a defesa autonomia da vontade e a tutela da confiança e da boa-fé objetiva, no que tange à responsabilidade pela informação, pelo conselho e pela recomendação nas relações entre particulares.

Como bem ensina Teresa Ancona Lopez, a participação do poder discricionário do julgador é enorme, pois estamos diante de um sistema aberto, "que acompanhará a realidade social diuturnamente e, mais facilmente, conseguirá realizar os valores da função social, da ética e da eqüidade, enfim, da justiça". ${ }^{439}$

Esse deve ser o norte para a imputação de responsabilidade pelos conselhos,informações e recomendações em situação jurídica que não esteja amparada por uma relação contratual.

438 Nelson Nery Junior, Ações de indenização fundadas no uso do tabaco. Responsabilidade civil pelo fato do produto: julgamento antecipado da lide. Ônus da Prova e cerceamento de defesa. Responsabilidade civil e seus critérios de imputação. Autonomia privada e dever de informar. Autonomia privada e risco social. Situações de agravamento de risco, cit., p. 391.

439 Teresa Ancona Lopez, Principais linhas da responsabilidade civil no direito brasileiro contemporâneo, in: Antonio Junqueira de Azevedo; Heleno Taveira Tôrres; Paolo Carbone), Princípios do novo Código Civil brasileiro e outros temas. Homenagem à Tullio Ascarelli, São Paulo: Quartier Latin, 2008, p. 22. 


\section{CONSIDERAÇÕES FINAIS}

O conhecimento e a informação permitem que o homem seja livre, garantindo-lhe o direito de escolha e a liberdade de pensamento, de opinião e de atitude, para buscar a sua realização pessoal e explorar as suas potencialidades. ${ }^{440}$

Notória é a importância do conhecimento e da informação para o pleno desenvolvimento das relações humanas, fundadas no respeito à individualidade, na consideração recíproca e em princípios de equidade, de forma a possibilitar a consecução do bem-estar social e da plenitude da vida.

A informação exerce, pois, um papel fundamental nas relações intersubjetivas, acentuado, nos dias de hoje, pela velocidade dos avanços tecnológicos, pelo uso generalizado de novos equipamentos e pelo consequente aumento da competitividade decorrente da globalização.

Essa verdadeira revolução na informação e, por conseguinte, no conhecimento, não se limita aos métodos de organização da sociedade, mas produz reflexos em todos os aspectos da vida humana.

Com efeito, em todas as ações humanas ocorre a troca de informações. Das mais desinteressadas àquelas em que existe um declarado interesse econômico, o fato é que o ser humano não pode prescindir da informação, recebida e transmitida a partir de um agir comunicativo cada vez mais intenso e dinâmico.

440 "O homem difere essencialmente dos animais não como possuidor de razão ou inventor de ferramentas, mas como ser capaz de escolha, alguém que se define por escolher, não por ser escolhido; o cavaleiro, não o cavalo; o que busca fins e não unicamente os meios, e cada um desses fins persegue à sua própria maneira, segundo o corolário de que tanto mais diversas as maneiras, mais ricas se tornam as vidas dos homens; quanto mais amplo o campo de ação recíproca entre os indivíduos, maiores as oportunidades do novo e inesperado; tanto mais numerosas as possibilidades de se alterar seu próprio caráter numa direção inédita ou inexplorada, mais trilhas abertas diante de cada indivíduo e mais extensa será sua liberdade de ação e de pensamento" (Isaiah Berlin, Prefácio à 3. " edição do Ensaio sobre "a liberdade”, John Stuart Mill, São Paulo: Martins Fontes, 2000, p. $\mathrm{XIII} / \mathrm{XIV})$. 
Assim, os sujeitos que participam desse processo comunicativo transmitem fatos de maneira objetiva, manifestam suas opiniões, expressam seu pensamento, exortam a prática de determinados atos, transferem riquezas, realizam operações de troca, enfim, praticam uma série de ações essenciais para o desenvolvimento da vida social.

Nesse relacionamento incessante, em que a liberdade de expressar e tornar públicas as opiniões é inseparável da liberdade de pensamento, a confiança constitui valor de primeira grandeza, sem a qual o trato social não ocorreria.

Todavia, uma completa harmonia nas relações intersubjetivas constitui ideal utópico em uma sociedade pautada pela ótica do consumo, do acúmulo de riquezas e por um exacerbado individualismo, o que faz com que a confiança mínima necessária para a convivência social seja quebrada das mais variadas formas.

O reflexo dessa quebra da confiança na difusão de informações e na prestação de conselhos ou de recomendações pode resultar em danos à pessoa ou ao patrimônio, impondo-se a busca de soluções para evitar a ocorrência desses efeitos danosos ou para promover a sua reparação.

Diversas são as soluções apresentadas pelos mais distintos sistemas para o problema decorrente da responsabilidade por conselhos, informações e recomendações.

Assim, no Código Civil português, mais precisamente em seu art. 485.', existe dispositivo expresso estabelecendo que os simples conselhos, recomendações ou informações não geram responsabilidade para aquele que os deu, salvo nas hipóteses em que existe um dever de prestá-los e se tenha procedido com dolo ou culpa, ou nos casos em que o procedimento do agente constitua um fato punível. ${ }^{441}$

${ }^{441}$ "Artigo 485. ${ }^{\circ}$ (Conselhos, recomendações ou informações) 1. Os simples conselhos, recomendações ou informações não responsabilizam quem os dá, ainda que haja negligência da sua parte. 2. A obrigação de indemnizar existe, porém, quando se tenha assumido a responsabilidade pelos danos, quando havia o dever jurídico de dar conselho, recomendação ou informação e se tenha procedido com negligência ou intenção de prejudicar, ou quando o procedimento do agente constitua facto punível." 
Como se vê, o sistema português parte da premissa de que as informações, os conselhos e as recomendações não geram responsabilidade, o que é essencial para que as relações intersubjetivas possam fluir de maneira natural, sem que a intervenção do Estado represente o seu engessamento.

No entanto, vincula o dever de reparar os danos causados pelos conselhos, informações ou recomendações à existência de culpa ou dolo por parte daquele que tinha um dever legal de prestá-los ou à ocorrência de um fato punível, o que deve ser entendido como um delito penal. ${ }^{442}$

Em nossa opinião, a opção do sistema português limita consideravelmente o âmbito da responsabilidade por conselhos, informações e recomendações, por condicioná-la à comprovação da culpa ou do dolo de quem a prestou, constituindo-se hipótese de responsabilidade subjetiva, ao passo que, em certas ocasiões, a responsabilidade do agente causador do dano poderá prescindir da prova de uma conduta dolosa ou culposa, como ocorre com o exercício abusivo do direito em que a responsabilidade é objetiva.

Além disso, a redação do art. $485 .^{\circ}$ do Código Civil português limita a responsabilidade in casu às hipóteses de alguém ter assumido o dever de prestar informações, conselhos ou recomendações ou de ter o dever legal de prestá-los ou, ainda, de se caracterizar um fato punível como crime, o que acaba por deixar muitas situações de fora da proteção legal.

Entretanto, é possível a ocorrência de danos causados por informações, conselhos ou recomendações em momento anterior à conclusão do contrato ou mesmo em decorrência de relações intersubjetivas que sequer estejam amparadas por uma relação contratual ou pelo dever legal de informação, muito menos por um delito penal, consoante demonstramos no capítulo quarto desta tese, o que demonstra a estreiteza do âmbito de incidência do art. $485 .^{\circ}$ do Código Civil português.

442 Vide Jorge Ferreira Sinde Monteiro, Responsabilidade por conselhos, recomendações ou informações, cit., p. 633. 
A previsão do mencionado art. $485 .^{\circ}$ do diploma civil lusitano teve inspiração $^{443}$ na antiga redação do $§ 676$ do BGB, ao dispor que o responsável por dar a outra pessoa um conselho ou recomendação "não fica obrigado à reparação do dano originado pelo seu seguimento, sem prejuízo da responsabilidade resultante de uma relação contratual ou de um ato ilícito". 444

No entanto, esse dispositivo legal do BGB referia-se ao contrato de mandato, o que demonstra a limitação de sua amplitude, mas acabou por servir de inspiração para o legislador português.

Com a reforma do BGB em 2002, alterou-se a redação do $\S 676$, suprimindo-se a sua antiga previsão acerca dos conselhos e recomendações, agora disciplinados pela cláusula geral de boa-fé insculpida no $\S 242^{445}$ do Código Civil alemão, que ainda trata de alguns efeitos das informações em outros dispositivos, como no caso das informações para o consumidor nas vendas à distância.

Na verdade, a evolução jurisprudencial alemã acabou por ampliar em muito a extensão da responsabilidade pelos conselhos e recomendações, não se limitando à antiga redação do $\S 676$ do BGB, pautando-se especialmente no princípio da boa-fé, que com a reforma de 2002 e toda uma sólida construção jurisprudencial acerca do tema, constitui o norte para a solução dos problemas que resultem de um conselho ou recomendação.

O mesmo acontece na França e na Itália, onde os tribunais fundamentam a responsabilidade nas cláusulas gerais da boa-fé e na quebra da confiança, mas promovendo a devida ponderação com a liberdade para negociar, contratar ou praticar outros atos da vida civil, levando-se em consideração que as pessoas devem poder fazer suas próprias escolhas e optar por aquilo que pretendem ou não divulgar a outrem.

443 Vide Jorge Ferreira Sinde Monteiro, Responsabilidade por conselhos, recomendações ou informações, cit., p. 620.

444 Idem, ibidem, p. 588.

445 “ $\$ 242$ Prestação segundo a boa-fé. O devedor está obrigado a cumprir a prestação segundo as exigências da boa-fé conforme os usos do tráfico." 
Essa parece ser a solução mais adequada, especialmente no sistema brasileiro, em que existe uma ordem de valores a impor um dever geral de conduta ética, leal e honesta, que serve de fundamento para uma responsabilidade pela confiança, cujas bases foram aqui expostas, sem se descurar da autonomia da vontade e do princípio da liberdade.

Assim, é preciso realizar o necessário sopesamento dos interesses envolvidos, a fim de se chegar a uma solução harmônica em que se tutele a confiança sem se extirpar a autonomia da vontade, ambos valores fundamentais de nosso ordenamento.

Para tanto, não há a necessidade de se demandar pela promulgação de novas leis ou de dispositivos legais nos moldes do art. $485 .^{\circ}$ do Código Civil português, pois demonstramos que o nosso sistema jurídico já possui os mecanismos necessários para a solução dos problemas decorrentes da responsabilidade por informações, conselhos ou recomendações, consubstanciados pelo reconhecimento de uma responsabilidade pela confiança.

Há que se frear esse verdadeiro furor legislativo característico dos últimos anos, posto existir em nosso ordenamento um sistema aberto, exatamente para se amoldar à evolução da sociedade, fundado em uma base de valores que se incorporaram à humanidade, a partir de seu desenvolvimento histórico e cultural.

Assim, não se deve sustentar as mudanças na base valorativa de nosso ordenamento jurídico, mas esperar pela promulgação de novas leis que as concretizem. Caso contrário, a única mudança permitida seria aquela sugerida pelo príncipe de Falconeri, clássico personagem da obra-prima de Giuseppe Tomasi di Lampedusa (Il Gattopardo): tudo deve mudar para que tudo fique como está.

Os fundamentos da responsabilidade pela confiança estão alicerçados na ordem de valores insculpida pela Constituição Federal de 1988, e os mecanismos para a sua irradiação pelo direito privado estão dispostos em nosso sistema através de seus princípios, regras, cláusulas gerais e padrões. Cabe promover a sua aplicação. 


\section{CONCLUSÃO}

Em nossa opinião, nosso sistema dá guarida a uma responsabilidade pela confiança civil que decorre da violação desse dever ético de conduta, essencial às relações intersubjetivas, que impõe o dever de reparar os danos por ela causados.

Essa responsabilidade pela confiança não constitui uma terceira via da responsabilidade civil, mas decorre de um valor fundamental de nossa ordem jurídica, que se irradia por todas as relações de direito privado, ingressando no ordenamento através dos princípios, regras, cláusulas gerais e padrões que compõem o sistema aberto do direito privado brasileiro.

Por conseguinte, ao lado do dever de segurança, expressão do neminem laedere, outra fonte da obrigação de reparar os danos consiste na valoração jurídica da confiança, o que leva a norma a imputar dever geral de conduta cuja concreção se verifica por meio do princípio da boa-fé objetiva. ${ }^{446}$

Desse modo, a ampla proteção do ethos da confiança, enquanto valor jurídico fundamental de nosso ordenamento, constitui o postulado jurídico dessa obrigação de reparar os danos, que possui como fundamento a dignidade humana e o solidarismo social, objetivos da República e impostos a todos aqueles que atuem em nosso sistema.

\footnotetext{
446 “A remissão formal para a boa-fé reúne todas as condições para, sem compromissos, exprimir essas exigências. Pela tradição romanística, a boa-fé está vocacionada para normatizar as relações entre pessoas específicas e, devidamente reforçada pela prática comercial do século XIX, para reger o tráfego negocial, à míngua de preceitos expressos. Pela sua dimensão sistemática, ela concatena lugares distantes, aproximados pelas exigências ordenadoras de um Direito que, porque positivo e logo efetivo, deve ter um qualquer sentido global. Pela elaboração científica, ela permite ver luz onde, de outro modo, reina o empirismo. Pela sua consagração legal, ela confere a todas as soluções que patrocine, uma viabilidade da qual, em termos realísticos, seria inoportuno desdenhar" (António Manuel da Rocha e Menezes Cordeiro, Da boa-fé objetiva no direito civil, cit., p. 563).
} 
Como dito, esse ethos da confiança significa resgatar as disposições morais das relações humanas, estimulando o comportamento ético e probo, a lealdade de tratamento e o respeito à esfera jurídica de outrem.

O reconhecimento da existência de uma responsabilidade pela confiança em nosso sistema resolve a contento os problemas decorrentes da responsabilidade por conselhos, informações ou recomendações, especialmente no que tange à controvertida fase que antecede a celebração dos contratos.

Assim, afirmamos que a responsabilidade civil é una e possui dois regimes distintos decorrentes de opção do legislador: contratual ou delitual. Somente através da apreciação casuística será possível verificar qual dos regime deverá ser adotado, podendo ser aquele decorrente do contrato, desde que existente um vínculo contratual, ou do delito, na ausência de vinculação contratual entre as partes.

Faça-se a ressalva, porém, que o recurso à confiança e à boa-fé objetiva não deve ser realizado de forma generalizante e sem nenhum critério, completamente afastado de nosso sistema jurídico, que possui como valores fundamentais a tutela da liberdade e da autonomia privada.

A necessária e cuidadosa ponderação entre esses princípios deve constituir o norte do operador do direito, a fim de preservar a harmonia do sistema, evitando-se a disseminação de decisões iníquas e buscando-se o ideal de construção de uma ordem jurídica justa e solidária.

Ao dever de informar corresponde o dever de manter-se informado, assim como não se deve ampliar o âmbito das ações ressarcitórias de forma generalizante, a fim de ver reparados todos e quaisquer danos sofridos no trato social, sob pena de engessar as relações de troca e de inviabilizar o desenvolvimento econômico e comercial de nossa sociedade, posto que o risco, consoante já dito, é inerente à vida em sociedade nos dias de hoje. 
Dessa forma, não se pretende chegar à conclusão de que quaisquer conselhos ou recomendações levem a um dever de indenizar toda vez que frustrarem as expectativas de seu destinatário, pois ninguém está obrigado a seguir um conselho ou dar ouvidos a uma recomendação.

A tutela jurídica excessiva também pode significar uma ingerência indevida do Estado perante a autonomia privada, e o excesso de proteção pode gerar decisões iníquas e efeitos contrários ao esperado, como o engessamento das relações de troca e da circulação de riquezas.

A sociedade espera do direito um solucionador para os seus problemas, pois a contínua discussão acerca do indivíduo e das relações intersubjetivas, a cooperação e a busca por soluções que sejam racionalmente aceitáveis para todos integram a construção de um projeto coletivo de realização e de justiça distributiva.

Neste contexto, cabe efetivar a devida ponderação entre a autonomia da vontade e a tutela da confiança para se encontrar a melhor solução para o caso concreto, fazendo-se a distinção entre os danos causados em decorrência da troca de informações conselhos ou recomendações, que devem ser devidamente reparados, e os simples prejuízos criados pelo convívio social e que devem ser suportados por aquele que os sofrer.

Afinal, a sociedade espera do Direito um solucionador para os seus problemas, pois a contínua discussão acerca do indivíduo e das relações intersubjetivas, integram a construção de um projeto coletivo de realização e de justiça distributiva.

Por conseguinte, impõe-se o repensar do indivíduo e de suas relações na vida em social, sob a égide dessa nova ordem de valores, que possui como diretrizes fundamentais a tutela prioritária da pessoa, de sua dignidade e a concretização do solidarismo social.

Afinal, como bem salienta Pietro Barcellona, "na época da organização técnica e da manipulação técnica da vida, repensar o indivíduo significa reconstituir as 
"margens" do acontecimento, do imprevisto, já que disso depende a conservação do espírito humano. Sem isso não há nem mesmo liberdade", 447

447 Pietro Barcellona, O egoísmo maduro e a insensatez do capital, cit., p.10. 


\section{REFERÊNCIAS BIBLIOGRÁFICAS}

AFONSO DA SILVA, Virgílio. A constitucionalização do direito. Os direitos fundamentais nas relações entre particulares. São Paulo: Malheiros, 2005.

AGUIAR DIAS, José de. Da responsabilidade civil. Rio de Janeiro: Forense, 1944. v. 1. 5. ed. Rio de Janeiro: Forense, 1973.

ALEXY, Robert. Teoria dos direitos fundamentais. Tradução de Virgílio Afonso da Silva. São Paulo: Malheiros, 2008.

ALPA, Guido. Corso di diritto contrattuale. Padova: Cedam, 2006.

. Responsabilidad civil y daño. Lineamentos y cuestiones. Tradução de Juan Espinoza Espinoza. Lima: Caceta Jurídica, 2001.

AMARAL, Francisco. Direito civil: introdução. 6. ed. Rio de Janeiro: Renovar, 2006. 7. ed. Rio de Janeiro: Renovar, 2008.

ANCONA LOPEZ, Teresa. Exercício abusivo do direito e suas limitações. In: NERY, Rosa Maria de Andrade; DONNINI, Rogério (Coord.). Responsabilidade civil: estudos em homenagem ao Professor Rui Geraldo Camargo Viana. São Paulo: RT, 2009.

Principais linhas da responsabilidade civil no direito brasileiro contemporâneo. In: Antonio Junqueira de Azevedo; Heleno Taveira Tôrres; Paolo Carbone (Coord.). Princípios do novo Código Civil brasileiro e outros temas. Homenagem à Tullio Ascarelli. Quartier Latin: São Paulo, 2008. 
- "Principais linhas da responsabilidade civil no direito brasileiro contemporâneo". In: Princípios do Novo Código Civil Brasileiro e outros temas. Homenagem à Tullio Ascarelli (Coord. Antonio Junqueira de Azevedo, Heleno Taveira Tôrres e Paolo Carbone). Quartier Latin: São Paulo, 2008.

. O dano estético. 3. ed. São Paulo, RT, 2004.

. Princípio da precaução e evolução da responsabilidade civil. 2008. f. 225.

Tese (Concurso de Professor Titular de Direito Civil) - Faculdade de Direito da Universidade de São Paulo, São Paulo.

ARENDT, Hannah. A condição humana. 10. ed. Tradução de Roberto Raposo. Rio de Janeiro: Forense Universitária, 2008.

ASCENÇÃO, José de Oliveira. Direito civil: Teoria geral. Relações e situações jurídicas. Coimbra: Coimbra Ed., 2002. v. 3.

. Direito civil: teoria geral. Ações e fatos jurídicos. 2. ed. Coimbra: Coimbra Ed., 2003. v. 2.

AZERRAD, Marcos Edgardo; FLORIO, Guillermo Alberto; AZERRAD, Marta Suzana. El secreto profesional y el deber de confidencialidad. Mendoza: Ediciones Juridicas Cuyo, 2003.

AZEVEDO, Álvaro Villaça. O novo Código Civil Brasileiro: tramitação; função social do contrato; boa-fé objetiva; teoria da imprevisão e, em especial, onerosidade excessiva (laesio enormis). In: ARRUDA ALVIM; CERQUEIRA CÉSAR, Joaquim Pontes de; ROSAS, Roberto (Coord.). Aspectos controvertidos do novo Código Civil: escritos em homenagem ao Ministro José Carlos Moreira Alves. São Paulo, RT, 2003.

AZEVEDO, Antonio Junqueira de. Caracterização jurídica da dignidade da pessoa humana. Estudos e pareceres de direito privado. São Paulo: Saraiva, 2004. 
Insuficiências, deficiências e desatualização do Projeto de Código Civil na questão da boa-fé objetiva nos contratos, $R T$, São Paulo: RT, v. 775, maio de 2000.

. Negócio jurídico: existência, validade e eficácia. 4. ed. São Paulo: Saraiva, 2002.

. Novos estudos e pareceres de direito privado. O direito ontem e hoje. Crítica ao neopositivismo constitucional e insuficiência dos direitos humanos. São Paulo: Saraiva, 2009.

. Responsabilidade pré-contratual no Código de Defesa do Consumidor: estudo comparativo com a responsabilidade pré-contratual no direito comum. Revista de Direito do Consumidor, São Paulo: RT, n. 18, 1996.

BARBOSA, Mafalda Miranda. Liberdade vs. responsabilidade. A precaução como fundamento da imputação delitual? Coimbra: Almedina, 2006.

BARCELLONA, Pietro. O egoísmo maduro e a insensatez do capital. Tradução de Sebastião José Roque. São Paulo: Ícone, 1995.

BECK, Ulrich. A reinvenção da política: rumo a uma teoria da modernização reflexiva. In: ; GIDDENS, Anthony; LASH, Scott. Modernização reflexiva. Tradução de Magda Lopes. São Paulo: Unesp, 1997.

BERLIN, Isaiah. Prefácio à 3. a edição. Ensaio sobre “A Liberdade”. John Stuart Mill. São Paulo: Martins Fontes, 2000.

BETTI, Emilio. Teoria geral do negócio jurídico. Tradução de Fernando de Miranda. Coimbra: Coimbra Editora, 1969. t. I.

BILBAO UBILLOS, Juan María. “¿En qué medida vinculan a los particulares los derechos fundamentales?”. In: SARLET, Ingo Wolfgang (Org.). Constituição, 
direitos fundamentais e direito privado. 2. ed. Porto Alegre: Livraria do Advogado, 2006.

BITTAR, Carlos Alberto. O direito civil na Constituição de 1988. 2. ed. São Paulo: RT, 1990.

BOBBIO, Norberto. A era dos direitos. 10. ed. Tradução de Carlos Nelson Coutinho. São Paulo: Campus, 1992.

. O futuro da democracia. Tradução de Marco Aurélio Nogueira. São Paulo: Paz e Terra, 2000.

BODIN DE MORAES, Maria Celina. Apresentação. In: MORAES, Maria Celina Bodin de (Coord.). Princípios do direito civil contemporâneo. Rio de Janeiro: Renovar, 2006.

BONAVIDES, Paulo. Curso de direito constitucional. 24. ed. São Paulo: Malheiros, 2009.

CAMPOS, Diogo Leite de. Nós. Estudos sobre os direitos da pessoa. Coimbra: Almedina, 2004.

CANARIS, Claus-Wilhelm. Die Vertrauenshaftung im deutschen Privatrecht. München: Beck Verlag, 1971 (reimpr. Nendeln. 1981). Apud CARNEIRO DA FRADA, Manuel Antonio de Castro Portugal. Teoria da confiança $e$ responsabilidade civil. Coimbra: Almedina, 2004.

. Direitos fundamentais e direito privado. Coimbra: Almedina, 2006.

. Pensamento sistemático e conceito de sistema na ciência do direito. 4. ed. Tradução de António Menezes Cordeiro. Lisboa: Fundação Calouste Gulbekian, 2008. 
CANOTILHO, José Joaquim Gomes. Direito constitucional e teoria da Constituição. 3. ed. Coimbra: Almedina, 1999.

CARNEIRO DA FRADA, Manuel Antonio de Castro Portugal. Teoria da confiança e responsabilidade civil. Coimbra: Almedina, 2004.

CAVALIERI FILHO, Sérgio. Programa de responsabilidade civil. 7. ed. São Paulo: Atlas, 2007.

CHAVES, Antônio. Responsabilidade pré-contratual. Rio de Janeiro: Forense, 1959.

COUTINHO DE ABREU, Jorge Manuel. Do abuso de direito. Ensaio de um critério em direito civil e nas deliberações sociais. Coimbra: Almedina, 2006.

COUTO E SILVA, Clóvis do. A obrigação como processo. Reimpressão. Rio de Janeiro: FGV, 2007.

DARMAISIN, Stéphane. Le contrat moral. Paris: Librarie Générale de Droit et de Jurisprudence, 2000.

DÁVILA, Sérgio. Folha de S.Paulo, 19 dez. 2008. Caderno Dinheiro.

DELFIM NETTO, Antonio. Folha de S.Paulo, 10 dez. 2008, Seção Opinião.

DEL VECCHIO, Giorgio. Los principios generales del derecho. 3. ed. Tradução de Juan Ossorio Morales.Barcelona: Bosch, 1971.

DEPERON, Mariana Pazianotto. Responsabilidade civil pela ruptura ilegítima das tratativas. Curitiba: Juruá, 2009.

DICIONÁRIO ESCOLAR LATINO-PORTUGUÊS. Organização de Pe. H. Koehler S. J. 5. ed. Porto Alegre: Globo, 1953. 
DICIONÁRIO HOUAISS DA LÍNGUA PORTUGUESA. Elaborado no Instituto Antonio Houaiss de Lexicografia e Banco de Dados da Língua Portuguesa Ltda. Organização de Antonio Houaiss e Mauro de Salles Villar. Rio de Janeiro: Objetiva, 2003.

DOMINGUES DE ANDRADE, Manuel A. Teoria geral da relação jurídica. v. 1, Sujeito e objecto. Coimbra, Almedina, 2003.

DONNINI, Rogério Ferraz. Responsabilidade civil pós-contratual. 2. ed. São Paulo: Saraiva, 2007.

DRAETTA, Ugo; LAKE, Ralph. Letters of intent and precontractual liability. International Business Law Journal, n. 7, 1993.

DWORKIN, Ronald. Levando os direitos a sério. 2. ed. Tradução de Nelson Boeira. São Paulo: Martins Fontes, 2007.

FABIAN, Christoph. O dever de informar no direito civil. São Paulo: RT, 2002.

FACHIN, Luiz Edson. O aggiornamento do direito civil brasileiro e a confiança negocial. Repensando fundamentos do direito civil brasileiro contemporâneo. Rio de Janeiro: Renovar, 1998.

. Questões de direito civil contemporâneo. Rio de Janeiro:Renovar, 2008.

FAGELLA, Gabrielle. Dei periodi precontrattuali e della loro vera ed esatta contruzione scientifica. Studi giuridici in onore di Carlo Fadda. Napoli: [s.n.], 1960. Apud DEPERON, Mariana Pazianotto. Responsabilidade civil pela ruptura ilegítima das tratativas. Curitiba: Juruá, 2009.

FEITOSA, Maria Luiza Pereira de Alencar Mayer. Paradigmas inconclusos: os contratos entre a autonomia privada, a regulação estatal e a globalização dos mercados. Coimbra: Coimbra Editora, 2007. 
FERRAZ JUNIOR, Tercio Sampaio. Liberdade de opinião, liberdade de informação: mídia e privacidade. Cadernos de Direito Constitucional e Ciência Política. Instituto Brasileiro de Direito Constitucional, São Paulo: RT, ano 6, n. 23, p. 28, abr.-jun. 1998.

FERREIRA DA SILVA, Jorge Cesa. A boa-fé e a violação positiva do contrato. Rio de Janeiro: Renovar, 2002.

FRIED, Charles. Contract as promise. A theory of contractual obligation. Cambridge (Massachusetts): Harvard University Press, 1981.

FRITZ, Karina Nunes. Boa-fé objetiva na fase pré-contratual. A responsabilidade précontratual por ruptura das negociações. Curitiba: Juruá, 2009.

GARCIA, Enéas Costa. Responsabilidade pré e pós-contratual à luz da boa-fé. São Paulo: Juarez de Oliveira, 2003.

GAVIÃO DE ALMEIDA, José Luiz. Novos rumos da responsabilidade civil por ato ilícito. In: (Org.). Temas atuais de responsabilidade civil. São Paulo: Atlas, 2007.

GODOY, Cláudio Luiz Bueno de. Função social do contrato. 3. ed. São Paulo: Saraiva, 2009.

GOMES, José Jairo. Responsabilidade civil e eticidade. Belo Horizonte: Del Rey, 2005.

GOMES, Orlando. Contratos. 26. ed. rev., atual. e aument. por Antonio Junqueira de Azevedo e Francisco Paulo de Crescenzo Marino. Rio de janeiro: Forense, 2007.

GONÇALVES, Carlos Roberto. Responsabilidade civil. 10. ed. São Paulo: Saraiva, 2007. 
HÄBERLE, Peter. Conversas acadêmicas com Peter Häberle. Tradução de Carlos dos Santos Almeida. São Paulo: Saraiva, 2009.

HABERMAS, Jürgen. A ética da discussão e a questão da verdade. Tradução de Marcelo Brandão Cipolla. São Paulo: Martins Fontes, 2007.

- A inclusão do outro: estudos de teoria política. Tradução de George Sperber, Paulo Astor Soethe e Milton Camargo Mota. São Paulo: Loyola, 2002.

. Direito e moral. Tradução de Sandra Lippert. Lisboa: Instituto Piaget, 1999.

HESSE, Konrad. Elementos de direito constitucional da República Federal da Alemanha. Tradução de Luís Afonso Beck. Porto Alegre: Sergio Antonio Fabris, 1998.

HIRONAKA, Giselda Maria Fernandes Novaes. Responsabilidade pressuposta. Belo Horizonte: Del Rey, 2005.

. Responsabilidade pressuposta - Evolução dos fundamentos e de paradigmas da responsabilidade civil na contemporaneidade. In: DELGADO, Mario Luiz; ALVES, Jones Figueiredo (Coord.). Novo Código Civil: questões controvertidas - Responsabilidade civil. São Paulo: Método, 2006. v. 5.

JHERING, Rudolph Von. Culpa in contrahendo oder Schadensersatz bei nichtigen oder nicht zur Perfektion gelangten Verträgen. Jhering Jarbücher für die Dogmatik des bürgerlichen Rechts, 1861 .

JONAS, Hans. O princípio responsabilidade, ensaio de uma ética para a civilização tecnológica. Tradução do original alemão Marijane Lisboa e Luiz Barros Montez. Rio de Janeiro: Contraponto, PUC-Rio, 2006.

JOURDAIN, Patrice. Les principes de la responsabilite civile. 2. ed. Paris: Dalloz, 1994. 
KANT, Immanuel. Crítica da razão pura. Tradução de Lucimar A. Coghi Anselmi e Fulvio Lubisco. São Paulo: Ícone, 2007.

LAFER, Celso. Hannah Arendt. Pensamento, persuasão e poder. 2. ed. São Paulo: Paz e Terra, 2003.

LARENZ, Karl. Derecho de obligaciones. Versão Espanhola de Jaime Santos Briz. Madrid: Revista de Derecho Privado, 1959. t. I.

Versão Espanhola de Jaime Santos Briz. Madrid: Editorial Revista de Derecho Privado, 1959. t. II.

. Derecho justo. Fundamentos de etica juridica. Tradução de Luiz Díez-Picazo. Madrid: Civitas, 2001.

LIMA, Alvino. Da culpa ao risco. São Paulo: RT, 1938.

LISBOA, Roberto Senise. Da confiança como valor fundamental e princípio geral do negócio jurídico. 2009. Tese (Concurso de Professor Titular de Direito Civil da Faculdade de Direito da Universidade de São Paulo). São Paulo.

LORENZETTI, Ricardo Luis. Tratado de los contratos: parte general. Buenos Aires: Rubinzal - Culzoni, 2004.

LUHMANN, Niklas. Confianza. Tradução de Amada Flores.Barcelona: Antrophos; México: Universidad Iberoamericana, 1996.

MANDUCA, Paulo César. Responsabilidade civil e responsabilidade social: a construção da sociabilidade no Brasil de hoje e de amanhã. In: GAVIÃO DE ALMEIDA, José Luiz (Org.). Temas atuais de responsabilidade civil. São Paulo: Atlas, 2007. 
MARQUES, Claudia Lima. A chamada nova crise do contrato e o modelo de direito privado brasileiro: crise de confiança ou de crescimento do contrato? In:

(Org.). A nova crise do contrato: estudos sobre a nova teoria contratual. São Paulo: RT, 2007.

. Contratos no Código de Defesa do Consumidor. 3. ed. São Paulo: RT, 1998.

MARTINS, Fernando Rodrigues. Princípio da justiça contratual. São Paulo: Saraiva, 2009.

MARTINS-COSTA, Judith. A boa-fé no direito privado. São Paulo: RT, 1999.

. Os avatares do abuso de direito e o rumo indicado pela boa-fé objetiva. In: TEPEDINO, Gustavo (Org.). Direito civil contemporâneo: novos problemas à luz da legalidade constitucional. São Paulo: Atlas, 2008.

MAZEAUD, Henri; MAZEAUD, Leon; TUNC, André. Tratado teórico y práctico de la responsabilidad civil delictual y contractual. 5. ed. Tradução de Luis AlcaláZamora Y Castillo. Buenos Aires: Ediciones Jurídicas Europa-América, 1957. t. I, v. 1 .

__ _ Tratado teórico y práctico de la responsabilidad civil delictual y contractual. 5. ed. Tradução de Luis Alcalá-Zamora Y Castillo. Buenos Aires: Ediciones Jurídicas Europa-América, 1962. t. I, v. 2.

MELLO, Marcos Bernardes de. Teoria do fato jurídico: plano da existência. 15. ed. São Paulo: Saraiva, 2008.

MENEZES CORDEIRO, António Manuel da Rocha e. Da boa-fé objetiva no direito civil. Coimbra: Almedina, 2001. . Tratado de direito civil português. Parte geral. Coimbra: Almedina, 2007. t. I. 
Introdução à edição portuguesa da obra de Claus-Wilhelm Canaris. Pensamento sistemático e conceito de sistema na ciência do direito. 4. ed. Tradução de António Menezes Cordeiro. Lisboa: Fundação Calouste Gulbekian, 2008.

MIRAGEM, Bruno. Função social do contrato, boa-fé e bons costumes: nova crise dos contratos e a reconstrução da autonomia negocial pela concretização das cláusulas gerais. In: MARQUES, Claudia de Lima (Org.). A nova crise do contrato: estudos sobre a nova teoria contratual. São Paulo: RT, 2007.

MIRANDA, Jorge. Manual de direito constitucional. t. IV: Direitos fundamentais. 3. ed. Coimbra: Coimbra Ed., 2000.

MOTA PINTO, Carlos Alberto da. Teoria geral do direito civil. 3. ed. Coimbra: Coimbra Ed., 1996.

MOTA PINTO, Paulo da. Interesse contratual negativo e interesse contratual positivo.

Coimbra: Coimbra Editora, 2008. v. 1.

MOURA VICENTE, Dario. A responsabilidade pré-contratual no Código Civil brasileiro de 2002. Texto que serviu de base às conferências proferidas pelo autor no Recife, em Brasília e em Porto Alegre, no âmbito da II Jornada de Direito Civil promovida pelo Conselho da Justiça Federal do Brasil entre 17 e 25 de Novembro de 2003. Consulta realizada via internet no dia 20 de novembro de $2009 . \quad$ Disponível em: <eletrônico:http://www.fd.ul.pt/Portals/0/Docs/Institutos/ ICJ/LusCommune/VicenteDario4.pdf>.

MÜLLER, Friedrich. Teoria estruturante do direito. Tradução de Peter Naumann e Eurides Avance de Souza. São Paulo: RT, 2008.

NEGREIROS, Teresa. O princípio da boa-fé contratual. In: MORAES, Maria Celina Bodin de (Coord.). Princípios do direito civil contemporâneo. Rio de Janeiro: Renovar, 2006. . Teoria do contrato: novos paradigmas. 2. ed. Rio de Janeiro: Renovar, 2006. 
NERY, Rosa Maria de Andrade. Introdução ao pensamento jurídico e à teoria geral do direito privado. São Paulo: RT, 2008.

NERY JR., Nelson. Ações de indenização fundadas no uso do tabaco. Responsabilidade civil pelo fato do produto: julgamento antecipado da lide. Ônus da Prova e cerceamento de defesa. Responsabilidade civil e seus critérios de imputação. Autonomia privada e dever de informar. Autonomia privada e risco social. Situações de agravamento de risco. In: LOPEZ, Teresa Ancona (Coord.). Estudos e pareceres sobre livre-arbítrio, responsabilidade e produto de risco inerente. O paradigma do tabaco: aspectos civis e processuais. Rio de Janeiro: Renovar, 2009.

NETTO LÔBO, Paulo Luiz. Constitucionalização do direito civil. Revista de Informação Legislativa, Brasília, ano 36, n. 141, jan.-mar. 1999.

NICOLAU, Gustavo Rene. Efetiva aplicação da teoria do risco no Código Civil de 2002. In: DELGADO, Mario Luiz; ALVES, Jones Figueiredo (Coord.). Novo Código Civil: questões controvertidas - Responsabilidade civil, São Paulo: Método, 2006. v. 5.

NOVAIS, Jorge Reis. Direitos fundamentais: trunfos contra a maioria. Coimbra: Coimbra Ed., 2006.

NUNES, Antonio José Avelãs. O Estado Capitalista. Mudar para permanecer igual a si próprio. In: OLIVEIRA NETO, Francisco José Rodrigues de et al. (Org.). Constituição e Estado Social: os obstáculos à concretização da Constituição. São Paulo: RT; Coimbra: Coimbra Ed., 2008.

PACCHIONI, Giovanni. Elementi di diritto civile. 4. ed. Milão: Giuffrè, 1944.

PEREIRA, Caio Mário da Silva. Instituições de direito civil: Contratos. Declaração unilateral de vontade. Responsabilidade civil. 13. ed. rev. e atual. por Régis Fichtner. Rio de Janeiro: Forense, 2009. v. 3. 
Instituições de direito civil: introdução ao direito civil. Teoria geral do direito civil. 23. ed. rev. e atual. por Maria Celina Bodin de Moraes. Rio de Janeiro: Forense, 2009.

. Responsabilidade civil de acordo com a Constituição de 1988. 8. ed. Rio de Janeiro: Forense, 1998.

PEREIRA, Régis Fichtner. A responsabilidade pré-contratual. Rio de Janeiro: Renovar, 2001.

PERLINGIERI, Pietro. O direito civil na legalidade constitucional. Tradução de Maria Cristina De Cicco. Rio de Janeiro: Renovar, 2008.

. Perfis do direito civil: introdução ao direito civil constitucional. Tradução de Maria Cristina De Cicco. Rio de Janeiro: Renovar, 1999.

PLANIOL, Marcel. Traité élémentaire de droit civil. 11. ed. França: F. Pinchon Successeur, 1902. t. II. Apud RIPERT, Georges. A regra moral nas obrigações civis. Tradução de Osório de Oliveira. São Paulo: Livraria Acadêmica, 1937.

POPP, Carlyle. Responsabilidade civil pré-negocial: o rompimento das tratativas. Curitiba: Juruá, 2001.

POTHIER, R. J. Tratado de las obligaciones. Tradução de M.C. de la Cuevas. Buenos Aires: Ayala, 1947.

RABUT, A. La notion de faut en droit privè. Paris, 1949, n. 127. Apud SILVA, Wilson Melo da. Responsabilidade sem culpa. 2. ed. São Paulo: Saraiva, 1974.

RÁO, Vicente. Ato Jurídico. 4. ed. São Paulo: RT, 1997.

REALE, Miguel. Cinco temas do culturalismo. São Paulo: Saraiva, 2000. 
. Estudos preliminares do Código Civil. São Paulo: RT, 2006.

. Nova fase do direito moderno. São Paulo: Saraiva, 1990.

. O projeto do novo Código Civil. 2. ed. São Paulo: Saraiva, 1999.

RIFKIN, Jeremy. The age of access. New York: Ed. Jeremy P. Tacher e G. P. Putnam's Sons, 2002. Apud WALD, Arnoldo. A evolução do contrato no terceiro milênio e o novo Código Civil. In: ALVIM, Arruda; CERQUEIRA CÉSAR, Joaquim Portes de; ROSAS, Roberto). Aspectos controvertidos do novo Código Civil: escritos em homenagem ao Ministro José Carlos Moreira Alves. São Paulo: RT, 2003.

RODOTÀ, Stefano. A vida na sociedade da vigilância. A privacidade hoje. Organização, seleção e apresentação de Maria Celina Bodin de Moraes. Rio de Janeiro: Renovar, 2008.

RODRIGUES, Silvio. Dos vícios do consentimento. 3. ed. São Paulo: Saraiva, 1989.

ROPPO, Enzo. O contrato. Tradução de Ana Coimbra e M. Januário C. Gomes. Coimbra: Almedina, 2009.

SAMPAIO, Marília de Ávila e Silva. Aplicação dos direitos fundamentais nas relações entre particulares e a boa-fé objetiva. Rio de Janeiro: Lumen Juris, 2006.

SARMENTO, Daniel. Direitos fundamentais e relações privadas. 2. ed., 2. tir. Rio de Janeiro: Lumen Juris, 2008.

O neoconstitucionalismo no Brasil. In: LEITE, George Salomão; SARLET, Ingo Wolfgang (Coord.). Direitos fundamentais e estado constitucional. São Paulo: RT; Coimbra: Coimbra Ed., 2009. 
SCHAPP, Jan. Introdução ao direito civil. Tradução de Maria da Glória Lacerda Rurack e Klaus-Peter Rurack. Porto Alegre: Sergio Antonio Fabris, 2006.

SCHREIBER, Anderson. A proibição de comportamento contraditório. Tutela da confiança e venire contra factum proprium. 2. ed. Rio de Janeiro: Renovar, 2007.

. Novos paradigmas da responsabilidade civil. Da erosão dos filtros da reparação à diluição dos danos. São Paulo: Atlas, 2007.

SILVA, Wilson Melo da. Responsabilidade sem culpa. 2. ed. Saraiva: São Paulo, 1974.

SILVEIRA, Alípio. A boa-fé no Código Civil. São Paulo: Universitária de Direito, 1973. 2. ${ }^{\circ} \mathrm{v}$.

SINDE MONTEIRO, Jorge Ferreira. Responsabilidade por conselhos, recomendações ou informações. Coimbra: Almedina, 1989.

STIGLITZ, Rubén S. La obligación precontractual y contractual de información. El deber de consejo. Revista de Direito do Consumidor, São Paulo: RT, n. 22, abr.jun. 1997.

STUART MILL, John. A liberdade. São Paulo: Martins Fontes, 2000.

TELLES, Inocêncio Galvão. Manual dos contratos em geral. 4. ed. Coimbra: Coimbra Ed., 2002.

TEPEDINO, Gustavo. A tutela da personalidade no ordenamento civil-constitucional brasileiro. Temas de direito civil. Rio de Janeiro: Renovar, 1999.

Normas constitucionais e relações de direito civil na experiência brasileira. Temas de direito civil. Rio de Janeiro: Renovar, 2006. t. II. 
TOMASETTI JR., Alcides. O objetivo da transparência e o regime jurídico dos deveres e riscos de informação nas declarações negociais para consumo. Revista de Direito do Consumidor, São Paulo: RT, n. 4 (Número especial), 1992.

VASCONCELOS, Pedro Paes de. Teoria geral do direito civil. 4. ed. Coimbra: Almedina, 2007.

ZANETTI, Cristiano de Sousa. Responsabilidade pela ruptura das negociações. São Paulo: Juarez de Oliveira, 2005.

WARDE, Ibrahim. Fannie Mãe e Freddie Mac vão para o brejo. Jornal Lê Monde Diplomatique, Paris, out. 2008. 